\title{
INVENÇÃO DO POSSÍVEL: O USO E A PRODUÇÃO DE FILMES NAS AULAS DE HISTÓRIA
}

Dissertação apresentada à Faculdade de Educação da Universidade de São Paulo para obtenção do título de Mestre em Educação.

Área de concentração: Didática

Orientador: Prof. Dr. Jaime Francisco Parreira Cordeiro 


\section{DEDICATÓRIA}

A meus pais, Dargrey Monari (in memorian) e Osias Monari que seguiram caminhos diferentes, mas me conduziram à universidade pública, cada um a seu modo. A meu querido esposo Sérgio, revisor atento e dedicado. Ao jovem Lucas que dividia a atenção da mamãe com a biblioteca e o computador. A Sérgio Rocha, professor de história e inspiração de seriedade e disciplina. Aos meus alunos de ontem, que propiciaram um caminho de trocas e aprendizado, e aos de hoje e amanhã, pois após esta reflexão novos caminhos foram vislumbrados. 


\section{AGRADECIMENTOS}

Ao Prof. Dr. Jaime Francisco Parreira Cordeiro, que apostou na ideia do projeto e orientou minhas reflexões com precisas interferências. Ao professor Celso Favaretto, que me apresentou à condição pós-moderna e me reaproximou de Walter Benjamin. A professora Antonia Terra, que me orientou nesse caminhar desde o curso de especialização na Pontifícia Universidade Católica, na coleta de dados do relato de experiência.

Aos professores Neide Luzia de Rezende e Amaury Cesar Moraes, que leram um esboço deste trabalho na Qualificação, e sugeriram importantes considerações sobre o encaminhamento da pesquisa.

Aos amigos Karina Almeida, Simone Vusberg, Tânia Favorito, Maria Eliza Tomazzi, Paulo Rogério da Silva e Márcio Bianchi, companheiros de trabalho, que apostaram na conclusão favorável desta pesquisa.

Aos meus alunos que sempre perguntavam sobre o andamento da pesquisa, acompanhando de perto o desenvolvimento das ideias, e ansiando sua conclusão. 
“O professor de História, com sua maneira própria de ser, pensar, agir e ensinar, transforma seu conjunto de complexos saberes em conhecimentos efetivamente ensináveis, faz com que o aluno não apenas compreenda, mas assimile, incorpore e reflita sobre esses ensinamentos de variadas formas. É uma reinvenção permanente.” (Selva Guimarães Fonseca) 


\section{RESUMO}

MAURICIO, D. M. T. Invenção do possível: o uso e a produção de filmes nas aulas de História. 2010. 204 f. Dissertação (Mestrado) - Faculdade de Educação, Universidade de São Paulo, São Paulo, 2010.

O presente trabalho é resultado de uma experiência pedagógica sobre a utilização e a produção de filmes nas aulas de História, realizada entre os anos de 2007 e 2008, com alunos do $9^{0}$ ano do ensino fundamental de duas escolas da rede particular de São Paulo. Durante este período, a produção cinematográfica foi utilizada de duas maneiras: como objeto de análise e como modalidade narrativa. Na primeira, o objetivo foi a alfabetização do olhar; as obras foram exploradas em seus elementos constitutivos - enredo, personagens, trilha sonora, cenários, montagem, tomadas de câmera, símbolos presentes nas cenas etc. -, abordando-os tanto individualmente como de modo relacional e estudando seu papel na construção de uma narrativa coesa. Na segunda, os alunos produziram um filme ficcional, tendo como recorte histórico os governos de Getúlio Vargas e utilizando os estudos a respeito dos recursos do cinema como linguagem nas várias etapas da produção: seleção de recorte temático, elaboração de um discurso e sua transformação em um roteiro possível - construção do enredo, personagens e elementos de cena -, filmagem, seleção da trilha sonora, montagem, colocação dos créditos. A técnica escolhida foi o sequenciamento de imagens por computador, por ampliar as possibilidades de criação para além da atuação de pessoas na tela, bem como por favorecer a utilização de mídias na escola. Diante da rigidez da constituição de um currículo para o ensino de História, que afasta o aluno de sua ação social, pôde-se perceber que a realização deste trabalho permitiu que tivessem uma leitura mais aberta da História, ampliando o seu repertório frente ao ensino e à escola, pois nos filmes, mesmo quando aparentemente havia uma reiteração de uma memória de reprodução de informações, notava-se a presença de mensagens aludidas e até alegóricas, ou seja, a crítica foi potencializada por meio da especificidade da linguagem do cinema. $O$ resultado não foi a relativização do ensino de História, e sim a realização de um exercício através do qual, a partir da realidade presente e das representações que os alunos possuíam ou adquiriram no interior e fora da escola, houve uma valorização do conhecimento.

Palavras-chave: Ensino de História. Cinema. Produção discente. Experiência pedagógica. Cultura visual. 


\begin{abstract}
MAURICIO, D. M. T. Invention of the possible. 2010. 204 p. Dissertation (Master) Faculdade de Educação, Universidade de São Paulo, São Paulo, 2010.

The present work is the result of a pedagogic experiment on uses and production of movie pictures in History classes, undergone between 2007 and 2008, with fundamental grade's $9^{\text {th }}$ level students of two private schools in Sao Paulo. During this period, cinematographic production was used in two ways: as an object for analysis and as a narrative resource. In the first one, education of the glance was the goal; film works' constitutive elements were explored - screen plot, personages, soundtrack, scenarios, editing, camera views, symbols present at scenes etc. -, treated both individually and relationally, and studying their role on building a cohesive narrative. In the second one, students made a fictional film, having Getulio Vargas' government period as a frame and using their knowledge on filmmaking elements in all stages of production: selection of thematic frame, elaboration of a speech and its transformation into a possible screenplay - building the plot, personages and scene elements -, filming, selection of soundtrack, editing, credits. The chosen technique was image sequencing by computer, for it enhances creation possibilities beyond people's acting on a screen, as well as it favors the use of media in school. Given the rigidity on establishing a curriculum for History teaching, in which students are set apart from their social action, it was observed that this work has enabled them to have a more open-minded History reading, expanding their repertoire in terms of the learning process and the school, for in their films, even when apparently there was a reiteration of a memory of information reproduction, we noted the presence of alluded and even allegoric messages, that is, criticism was enhanced by means of the specificity of cinema language. The result was not to relativize History teaching, but to perform an exercise which, from present-day reality and from representations that students had or had gained inside and outside the school, lead to a gain in the value of knowledge.
\end{abstract}

Keywords: History teaching. Cinema. Students production. Pedagogic experiment. Visual culture. 


\section{SUMÁRIO}

APRESENTAÇÃ 0 ................................................................................................................................9

INTRODUÇÃ 0 .................................................................................................................................13

CAPÍTULO 1 A EXPERIÊNCIA PEDAGÓGICA...................................................................22

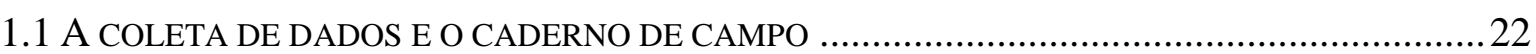

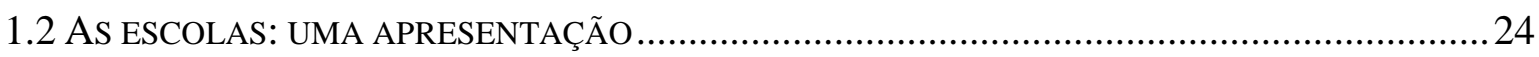

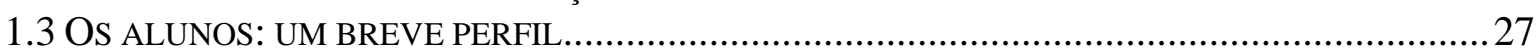

1.4 RELATO DE EXPERIÊNCIA: ATIVIDADES DESENVOLVIDAS EM 2007 E 2008 .......................... 31

CAPÍTULO 2 HISTÓRIA, CURRÍCULO E AS AULAS ..................................................67

2.1 ALGUMAS CONSIDERAÇÕES SOBRE O ENSINO DE HISTÓRIA NO BRASIL ..........................67

2.2 O PROGRAMA DE HISTÓRIA NAS ESCOLAS A E B: ANÁLISES A PARTIR DO MATERIAL

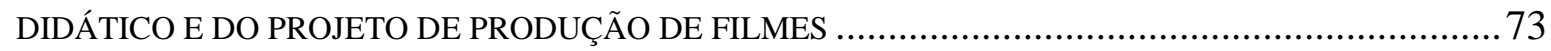

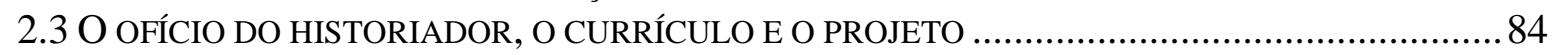

CAPÍTULO 3 CINEMA, HISTÓRIA E AS AULAS .......................................................91

3.1 CINEMA: UM BREVE HISTÓRICO DE SEU USO COMO MODALIDADE NARRATIVA.................91

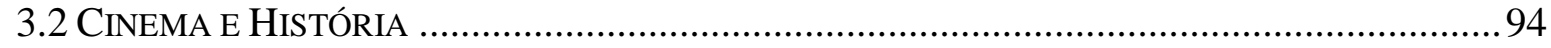

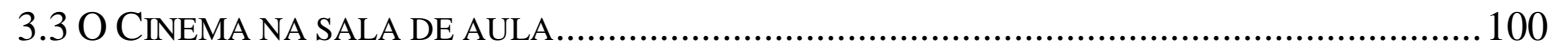

3.4 MOdOS DE USO DO CINEMA NO DESENVOLVIMENTO DA PESQUISA................................ 103

CAPÍTULO 4 ANÁLISE DOS FILMES...................................................................................111

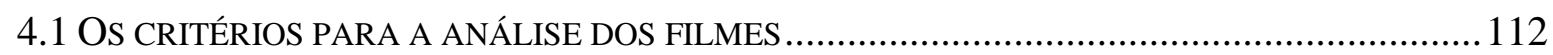

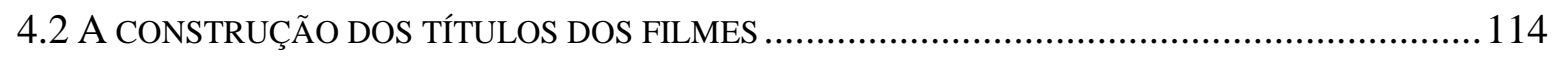

4.3 O ENREDO: OPÇÃO DE CONTEÚDO E ARTICULAÇÃO COM A FORMA.................................. 120

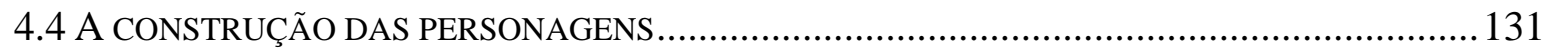

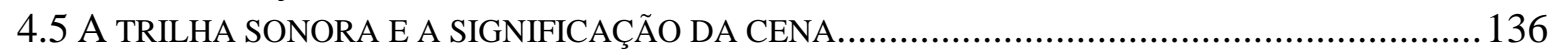

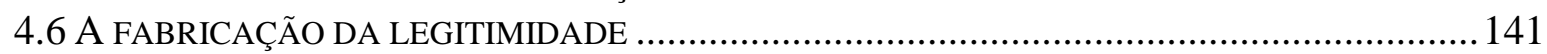

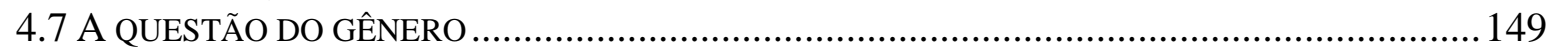

CAPÍTULO 5 AVALIAÇÃo DO POSSÍVEL..................................................................155

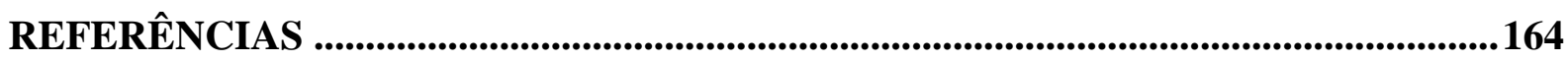

ANEXO A - FILMES PRODUZIDOS PELOS ALUNOS ....................................................171

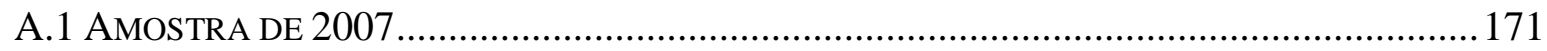

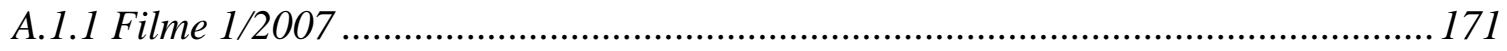

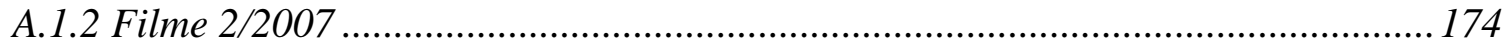

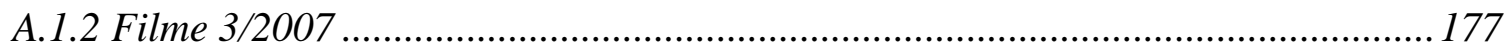

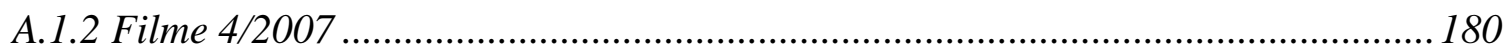

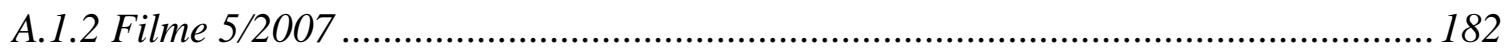

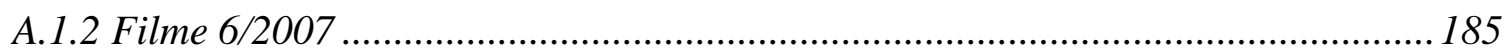

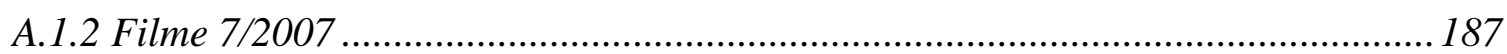

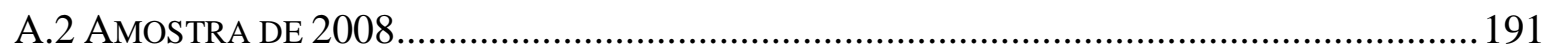

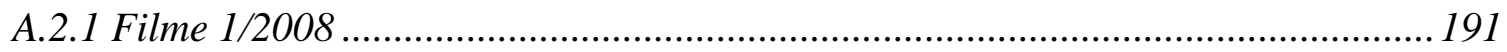

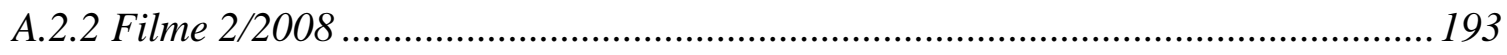

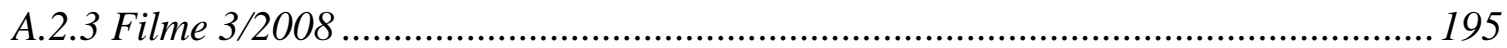

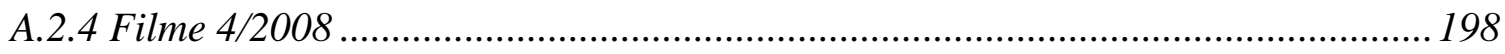


A.2.5 Filme 5/2008 


\section{APRESENTAÇÃO}

A concepção desta pesquisa seguiu um caminho peculiar. Ele foi gestado no interior de uma das escolas onde veio a se desenvolver posteriormente, na qual eu já lecionava há um ano e meio.

O projeto foi, desde o início, trabalhar com o cinema em sala de aula, tanto como objeto de estudo quanto como modalidade discursiva, com o objetivo de que os alunos realizassem um exercício autoral, ou seja, produzissem seus próprios filmes, sobre um tema da História. A proposta seria aplicada aos alunos do último ano do Ensino Fundamental, como uma tarefa de conclusão desse ciclo de estudos.

O modo como se organizava o trabalho docente nessa escola exigiu que a proposta fosse encaminhada por escrito, com a descrição e os objetivos das atividades. No entanto, mesmo com essa formalização do projeto, sua realização inicialmente não foi autorizada pela coordenação. A alegação foi de que a rigorosa distribuição de conteúdos a serem trabalhados em cada um dos bimestres do ano letivo inviabilizaria o desenvolvimento de atividades extras. Havia, na escola, uma forte tendência de se utilizar de aulas expositivas e exercícios de fixação como únicas formas de se trabalhar em sala de aula.

Pessoalmente foi frustrante saber que uma iniciativa como essa estava sendo negada, apesar de ter sido elaborado um projeto que justificava e explicava todo o processo. A realidade com a qual me confrontava ao entrar em cada uma das salas de aula em que lecionava era perceber, em grande parte dos alunos, certo descrédito frente às aulas de modo geral - e também às aulas de História. Essa atitude dos alunos não era exatamente pessoal, ou seja, não se tratava de uma oposição à professora, mas a um formato de aula e currículo em que eram excluídos.

O resultado havia se tornado complexo: indisciplina, desinteresse e baixo rendimento. É curioso o modo como a rotina do trabalho escolar tende a levar os professores a certa insensibilidade diante desse quadro de falta de adesão dos alunos.

Frente a esse quadro, procurava estreitar alguns vínculos com os alunos para que o a indisciplina fosse controlada. A escola conta com um sofisticado sistema de regras e punições, cujos procedimentos chegam a tomar boa parte do tempo da aula. Diante da exigência - e do rigor - de se manter o silêncio em sala de aula, apelei para a empatia com os alunos e busquei a adesão deles nas atividades que propunha. 
A recusa inicial do projeto pela coordenação me foi de tal modo significativa que o transformei em projeto de pesquisa e apresentei-o no processo de seleção para o programa de mestrado da Faculdade de Educação da Universidade de São Paulo, em 2006. A sua aceitação e o início do trabalho foi possível a partir da aposta do professor Jaime Cordeiro nessas ideias e no potencial desenvolvimento de um trabalho na área de Didática, particularmente para o ensino de História.

Ao retornar à escola, já no ano seguinte, com o certificado de ingresso no programa de mestrado, a realização do projeto em sala de aula foi autorizada - na ocasião, havia começado a trabalhar em outra escola pertencente ao mesmo grupo educacional, de modo que poderia desenvolver a pesquisa em ambos os locais. Talvez a aprovação no processo seletivo tenha legitimado a pesquisa, junto à coordenação, mas aparentemente não foi suficiente para que esta a valorizasse, pois em nenhum momento acompanhou as atividades ou questionou seu desenvolvimento, a produção dos alunos, ou mesmo os resultados obtidos.

As pesquisas realizadas por Bourdieu acerca da movimentação dos sujeitos em um determinado campo social - como o da educação, no qual as escolas se inserem - têm muito a esclarecer acerca das posições ocupadas nessas instituições e da concepção desse projeto. Elas indicam que para se ocupar posições - tanto as centrais quanto as da periferia nesses campos, é necessário ter-se o domínio de certos capitais, pois isto possibilita negociar o dinamismo constitutivo de cada um deles. No caso dessas escolas, não era o capital cultural que tinha preponderância na valorização do sujeito, mas sim o social, a capacidade de articular no habitus certa dissimulação de interesses e garantias, a partir de uma rede de apoio pessoal - grande parte dos professores que trabalham na escola foi contratada a partir da indicação de um funcionário, particularmente dos coordenadores; ou ainda, foram alunos da própria escola, em outros tempos.

Para atingir as posições centrais tendo apenas o conhecimento formalizado na Universidade de São Paulo - onde me graduei - e em cursos realizados no exterior, era necessário criar uma estratégia de ascensão, em que esse capital cultural se aproximasse do social. Bourdieu (1996) nos oferece algumas pistas. Uma delas é a identificação de um "interesse" pelo jogo: eu estava disposta a aumentar o número de aulas que tinha e também conquistar a simpatia da coordenação, bem como a dos alunos.

Deveria integrar-me, pagando o preço social para tanto, ou seja, o da cumplicidade. Tal deslocamento exigiu a aceitação inequívoca de determinadas atitudes, 
compreendidas aqui como habitus, tais como seguir a proposta de cumprir a quantidade de conteúdos que a escola determinava para ser desenvolvida a cada bimestre.

Sujeição interessante é a apreensão do habitus, uma vez que "sendo pessoal, o trabalho de aquisição é um trabalho do sujeito sobre si mesmo (fala-se em cultivar-se). O capital cultural é um ter que tornou ser, uma propriedade que se fez corpo e tornou-se parte integrante da pessoa, um habitus. (...) Pode ser adquirido, no essencial, de maneira totalmente dissimulada e inconsciente e permanece marcado por suas condições primitivas de aquisição" (BORDIEU, 1996, p. 74-75).

Ainda que eu tenha conseguido circular pelo campo educacional, a manutenção do habitus adquirido exigiria constante investimento. Neste sentido, o trabalho específico com o cinema poderia demonstrar o domínio, por minha parte, de um conhecimento extra, um saber tanto de análise quanto de produção que escapava ao espaço da formação universitária. Essas habilidades foram adquiridas em outros momentos específicos de investimento: fiz cursos sobre cinema e História - no Cineclube Pandora (do centro acadêmico do departamento de História da Universidade de São Paulo) e na Cinemateca Brasileira - e participei de festivais internacionais de animação - Anima Mundi.

Bourdieu também destaca as possibilidades de estratégia para se entrar na disputa: uma é a da ortodoxia e a outra a da heterodoxia. Na primeira, há a obediência aos padrões valorizados por determinados sujeitos, por meio do habitus incorporado por aquele que joga; seguir esses padrões é, de antemão, reconhecer a importância da disputa, e principalmente reconhecer a posição central de um determinado grupo. Na segunda, observa-se um percurso mais ousado do sujeito, mas igualmente ele reconhece as regras pertinentes ao funcionamento do jogo e o lucro do bem que está sendo disputado; no entanto, seu risco é maior.

O caminho escolhido por mim para sair da periferia e chegar a uma posição mais confortável foi o de utilizar os créditos do capital cultural que possuo - como o conhecimento específico de análise e produção de filmes - e o apoio dos alunos. O suporte a esse processo seria dado a partir dos resultados obtidos com a pesquisa que desenvolvia e também com a realização do mestrado. O apoio dos alunos seria fundamental, uma vez que eles participam dessa dinâmica de organização de posições de forma mais ou menos privilegiada. De todo modo, esses vínculos correspondem ao capital social, posto que há a comunicação dos alunos entre si, com relação às aulas e ao projeto.

Por essa razão, construí um projeto no qual os alunos poderiam trabalhar com um conhecimento específico que não é reconhecido pela escola, qual seja, a produção de mídia. Incluí também exercícios de análise fílmica, tanto de outros títulos quanto de seus próprios trabalhos. De modo geral, a utilização de recursos midiáticos é de competência exclusiva do 
professor. Existem os equipamentos apropriados na escola e um ou outro professor cria estratégias para sua utilização, principalmente como um veículo ilustrativo de suas aulas.

As apostas foram altas: trabalhar nas brechas do sistema pedagógico que a escola estabeleceu como caminho a ser percorrido, propondo exercícios tanto de análise de objetos como de produção autoral (e não meramente de reprodução), submeter essa experiência à minha própria análise, às avaliações periódicas do professor Jaime e a duas bancas examinadoras (a do Exame de Qualificação e à banca julgadora do trabalho final). Tratava-se de me pôr à prova, tanto naquilo que se refere à minha capacidade crítica de pesquisa, como também à minha prática docente.

Os limites e os resultados da relação entre as apostas e os riscos de uma experiência pedagógica que conduzi como docente e pesquisadora formam o corpo deste trabalho. Considero que a atividade foi frutífera, na medida em que me encontrei como uma professora reflexiva, reconheci fissuras em minha prática e, por meio do conhecimento de outras leituras, pude obter a justificativa de ações muitas vezes viciadas pela cultura escolar.

Os resultados dessa empreitada não são apenas aqueles visíveis - esta dissertação e suas implicações no campo cultural - mas relacionam-se também com um ganho afetivo, uma aproximação respeitosa junto aos alunos que fizeram os filmes. Percebo a reação dos alunos, a confiança que o exercício conferiu a alguns deles, também em outras disciplinas de sua grade curricular, como foi o caso de um grupo envolvido no projeto, que realizou um filme como modalidade discursiva para participar de um concurso público promovido pela editora Maximilian em 2009, tendo sido classificado entre os nove finalistas do Estado de São Paulo. Nessa ocasião, pude ouvir de um aluno: Eu continuo fazendo filme, Dani! 


\section{INTRODUÇÃO}

Retirar o objeto de seu invólucro, destruir sua aura, é a característica de uma forma de percepção cuja capacidade de captar "o semelhante no mundo" é tão aguda, que graças à reprodução ela consegue captá-lo até no fenômeno único (BENJAMIN, 1996, p. 171).

Um dos objetivos do presente trabalho foi buscar uma comunicação entre a História e a reprodução de conteúdos nas aulas, a qual não fosse centrada apenas na lógica dos livros didáticos, do vestibular, ou de um planejamento realizado pela coordenação.

O formato que o ensino de História assumia na escola em que lecionava era, acredito eu, um dos fatores que gerava marcante falta de adesão dos alunos diante das aulas, gerando duas situações visíveis: a indisciplina e a apatia. É certo que um envolvimento irrestrito dos alunos pode não corresponder à realidade escolar, mas havia pouco espaço para que eles participassem da aula com reflexões.

Neste contexto é oferecido aos alunos um formato de ensino de História em que o passado existe por si, sem contudo expressar relação com o presente.

Era uma vez o passado.

Ele agrupava acontecimentos, pessoas e coisas que não mais existiam. Sua importância para quem o invocava, entretanto, exigia que se provasse, com o máximo zelo, o estatuto real daquela existência pretérita. Muitas vezes, o puro passado era entendido e instituído na condição de origem, lugar de nascimento, início de práticas humanas.

Daí a necessidade de profissionais ou instituições que dedicassem suas vidas à recuperação, comprovação e preservação de tudo o que tinha sido. Costumavam-se estabelecer cuidadosos cordões sanitários entre o tempo sobre o qual se falava (o puro passado) e o tempo a partir do qual se falava (um ralo e menos importante presente), alegando-se que qualquer mistura entre ambos poderia ser fatal para o adequado conhecimento do primeiro (SILVA, 2006, p. 25-26).

Para interagir com esta memória era necessário criar uma estratégia em que as regras da escola fossem mantidas, além de propor exercícios em que os alunos pudessem se aproximar do ofício do historiador e refletir de modo pormenorizado sobre um determinado tema da História nacional.

Desta maneira, o projeto inseriu-se na realidade das escolas que dele participaram, na questão de que, nelas, pelo privilégio dado à quantidade de conteúdos comunicada aos alunos, acaba-se perdendo de vista uma das funções do conhecimento: o desenvolvimento das potencialidades intelectuais dos estudantes. Pretendia testar um exercício que se desenvolveria 
ao longo de um ano, e que ocuparia algumas aulas em cada bimestre. Os efeitos serão colocados à prova nas análises registradas nesta dissertação.

O caminho seguiu a fim de explicitar o processo geral do conhecimento histórico: a seleção, interpretação, construção de uma produção autoral e comunicação dessa mensagem ao público. Aproximar-se deste processo pretendia levar ao conhecimento dos alunos a configuração de que o saber é produzido por sujeitos sociais, inseridos numa dada realidade.

Poderia propor a leitura de um texto. Contudo estes alunos já desenvolvem uma gama de exercícios de leitura e interpretação de linguagem escrita, com o objetivo de tornálos mais críticos, e não pretendia insistir nessa modalidade. A construção de uma habilidade crítica aqui entendida como aprofundamento de níveis de leitura deveria contar principalmente com uma linguagem nova e potencial, com estas características.

Com o objetivo de propor este outro caminho para a aproximação do conhecimento histórico, em que a ação dos homens no tempo fosse privilegiada em detrimento da reprodução de uma sequência de informações, selecionei uma linguagem em particular: o cinema. Essa escolha pretendia oferecer um repertório específico do domínio técnico de sua constituição, mas também seria usada como objeto de estudo. Para isto seriam realizados exercícios bimestrais de sensibilização e estudo.

O trabalho com cinema possibilita uma dupla utilização deste recurso: como objeto de análise nas aulas de História - um documento-monumento de sua época em contínua relação com o presente - e como forma de comunicação dos alunos, um recurso midiático para divulgar uma determinada leitura da História. A linguagem escrita ocupa na escola um papel privilegiado: ela é a forma por excelência pela qual os alunos têm acesso a outros mundos e a outros tempos; é assim que registram seus discursos, fixam-nos na memória. Era necessário, nesta pesquisa, trabalhar com outro formato, e o cinema respondeu a este chamado.

O filme e a tradição do cinema geram configurações em que diferentes elementos da sinestesia podem ser evocados. O agente que inaugura essa percepção é a atenção. Para render o espectador há uma sofisticada combinação de construção de elementos como personagem, paisagem, música, enquadramento, entre outros, que trabalham no mesmo sentido: o espectador sabe que a profundidade não é real, mas entrega-se ao como se da ficção.

Em sala de aula, o uso do filme geralmente visa a sua leitura como texto a ser destrinchado na forma e no conteúdo. Nas aulas de História a preponderância é deste último. A alfabetização dos alunos para estes elementos nos aproxima da formação de uma cultura 
visual, ou seja, desenvolve o olhar como uma atividade nada inocente, mas dotada de sentidos. A riqueza de possibilidades da obra cinematográfica é singular: ela opera tanto como um ícone, que evoca alguma semelhança com a coisa representada, quanto como um índice, um signo que se refere ao objeto que ele denota em virtude de ter sido realmente afetado por este (XAVIER, 2008, passim). De outro modo, também a linguagem cinematográfica pode auxiliar no desenvolvimento de camadas de leitura, da mais explícita àquela do sentido alegórico.

Aqui a linguagem cinematográfica evidencia, de modo singular, algumas das características do ofício do historiador, tanto na análise e decupagem de cenas de uma obra quanto em várias etapas de sua produção - seleção de fontes, interpretação e veiculação das informações, atribuindo-lhes sentido; a montagem é a expressão mais significativa dessa aproximação. Tanto a História quanto o filme são partes da realidade - momentos capturados - e ambos necessitam ter unidade e coerência narrativa, para que sejam inteligíveis a outros sujeitos.

Para ampliar o uso do cinema em sala de aula, neste projeto ele seria também uma modalidade discursiva pela qual os alunos poderiam se aproximar da História. A produção de filmes por eles exigiria a mobilização de conhecimentos sobre a tecnologia pertinente a edição de imagens, sonorização, bem como a utilização da Internet como meio de pesquisa e de comunicação. Valorizar um conteúdo específico que não faz parte do currículo oficial da escola, mas que alguns estudantes dominam, oferece a possibilidade de outra instrumentalização do saber. $O$ fato de os alunos serem também consumidores de cinema permite que manifestem uma percepção intuitiva de suas características específicas de comunicação.

Cumpre destacar aqui, a relação cotidiana que os alunos das escolas onde o projeto foi aplicado possuem com essa mídia. Trata-se aqui do fato de eles assistirem a filmes com frequência, e também tomá-los como forma de lazer e parte de uma cultura de massa, status que possivelmente não os habilitam como objetos de estudo nas escolas. Iniciá-los no domínio dos elementos técnicos da produção fílmica, com o objetivo de usar esse saber para produzir um filme poderia despertar a adesão dos alunos. Soma-se a isto o caráter de produção coletiva da obra e ainda sua divulgação ao público - é o cinema que propicia a dialética entre a representação e o exibicionismo, potencializando a astúcia da mensagem veiculada.

A opção pela produção cinematográfica permitiu ainda a oportunidade de uso prático da tecnologia da comunicação. Os equipamentos são bens preciosos ao universo 
desses jovens, e a utilização desses recursos viabilizou um espaço para manifestarem o domínio de um saber que escapa àqueles trabalhados na escola. Inverte-se o jogo do conhecimento: são os alunos, e não mais o professor, que dominam a linguagem - em diversas ocasiões foram os próprios alunos que solucionaram os problemas técnicos que encontraram durante o desenvolvimento do trabalho.

O projeto com o cinema tornou-se o eixo organizador do curso de História desenvolvido em 2007 e 2008 para o $9^{\circ}$ ano do Ensino Fundamental, de modo que os conteúdos seriam desenvolvidos utilizando-se de uma linguagem específica, a qual os temas seriam referenciados. Porém não criei temas, pois para isso encontrava alguns impedimentos: o fato de o material didático ser apostilado e entregue apenas no início de cada bimestre aos alunos, as provas serem integradas para toda a rede de cinco escolas, dentre as quais aquelas em que o projeto se desenvolveu, existir um cronograma, a ser seguido pelos professores, para o desenvolvimento semanal das atividades, e que também conta com a fiscalização da coordenação.

Todo o conhecimento transformado em imagem nos filmes seria avaliado a partir da leitura sobre a memória histórica do governo do presidente Getúlio Vargas. Assim um tema que apresenta canonicidade dentro do próprio currículo de História seria manipulado. Qual seria o efeito de criar um sentido para o curso de História a partir de uma linguagem? O objetivo seria a valorização do conhecimento histórico?

As indicações de Walter Benjamin em A obra de arte na época de sua reprodutibilidade técnica (BENJAMIN, 1994) foram um dos caminhos para o balizamento frente a estas questões. A cada nova leitura do texto, outras modalidades eram percebidas. É certo que realizei algumas divagações sobre o tema, as quais talvez o texto não sustente em citações, mas o formato de História anunciada pelo autor as legitimam.

Uma das questões centrais é a constatação do potencial revolucionário do cinema, exatamente em sua marca, até então, mais criticada em relação às demais expressões da arte: sua capacidade de reprodução sem limites, e ao mesmo tempo de comunicação de massa. Aquilo que era irrevogável à obra de arte - sua aura - é descaracterizada na ação do cinema, dessacralizando seu valor litúrgico, tornando-a visível e possivelmente mais compreensível ao público comum.

Nesse sentido, o conceito de aura é fundamental. Nas palavras do autor:

Em suma, o que é a aura? É uma figura singular, composta de elementos espaciais e temporais: a aparição única de uma coisa distante, por mais perto que ela esteja. (...) Graças a essa definição, é fácil identificar os fatores sociais específicos que condicionam o declínio atual da aura. Ele deriva de 
duas circunstâncias, estreitamente ligadas à crescente difusão e intensidade dos movimentos de massas. Fazer as coisas "ficarem mais próximas" é uma preocupação tão apaixonada das massas modernas como sua tendência a superar o caráter único de todos os fatos através da sua reprodutibilidade. Cada dia fica mais irresistível a necessidade de possuir o objeto, de tão perto quanto possível, na imagem, ou antes, na sua cópia, na sua reprodução (BENJAMIN, 1996, p. 171).

Subtrair a aura de um objeto é desnudá-lo aos sujeitos que o apreciam. A aproximação que faço com estas proposições vai no sentido de fazer um exercício em que um tema da História nacional fosse posto à prova. Também não se trata de qualquer recorte. Sua escolha respondia à necessidade de um conteúdo canônico, ou seja, que tivesse preponderância na memória do ensino. Neste sentido a escolha pelo governo de Getúlio Vargas era importante.

Para chamar a atenção sobre a inércia narrativa que a escola oferece aos temas fulcrais que sustentam a unidade de explicação da História do Brasil, um destes foi utilizado no projeto. Apresentar um trabalho em que a canonicidade do conteúdo, e não de qualquer seleção, fosse tornada objeto de preparação de um discurso autoral por parte dos alunos, usando o cinema como modalidade discursiva poderia ser um exercício de desauratização?

Após o filme estar pronto, ele deveria ser veiculado, em sessões para os demais colegas, nas duas escolas onde o projeto se desenvolveu, e também na Internet. A exposição da obra dos alunos agiu no intuito de funcionar como uma espécie de auto-censura, ou seja, pretendia escapar apenas do julgamento da professora, e da avaliação de certo e errado. Submeter o trabalho ao público forçaria os grupos a se dedicarem a inserir em seus trabalhos uma estética juvenil, ou seja, obrigá-los-ia a operar com elementos discursivos que também eram inteligíveis para a faixa etária e para o grupo social ao qual pertenciam.

Nesse sentido, a linguagem que seria usada neste procedimento deveria cumprir o papel de abrir possibilidades de criação, interpretação do mundo, e também oferecer comunicação da produção às outras escolas.

É como se o mundo exterior fosse sendo urdido dentro da nossa mente e, em vez de leis próprias obedecesse aos atos de nossa atenção. (...) O cinema, ao invés de obedecer às leis do mundo exterior, obedece às da mente (MUNSTERBERG, 2003, p. 35-38).

A comunicação que a obra estabelece com o espectador foi um atributo que enriqueceu a experiência, na medida em que a participação afetiva deve ser considerada como estado genético e como fundamento estrutural do cinema (PUDOVKIN, 2003). Os alunos produtores de filmes necessitaram, de algum modo, refletir sobre os padrões culturais aos quais estavam submetidos para que fossem capazes de atingir o público, ainda que de modo 
implícito. Aqueles que assistiram aos trabalhos também completavam os discursos presentes nas obras.

O princípio que norteou a construção dos capítulos deste trabalho foi o da busca por uma racionalidade que favorecesse a utilização da experiência pedagógica e dos filmes produzidos pelos alunos como objetos para o encaminhamento de determinadas leituras. Sob este eixo, privilegiando a sustentação empírica dos resultados, propus a criação de cinco capítulos.

No primeiro capítulo encontram-se às considerações sobre os procedimentos que encaminharam a coleta das informações utilizadas para compor o relato da experiência. Optei por realizar minhas anotações em um caderno de campo, o que lhe conferiu um sentido de registro etnográfico. Para facilitar ao leitor o entendimento da descrição das atividades desenvolvidas com os alunos, optei por fazer uma breve apresentação das escolas em que o projeto foi realizado, com o objetivo de explicitar as suas características de funcionamento, uma vez que a constituição desses elementos ecoa nas práticas realizadas e na participação dos alunos durante o desenvolvimento das aulas.

Respeitando-se a realidade de que a experiência ocorreu em duas escolas diferentes, embora pertencentes à mesma rede de ensino, busquei pontuar as especificidades de cada uma delas. Os sujeitos desse processo mereceram apresentação: caracterizar o perfil dos alunos que participaram do projeto foi importante para entender as suas reações e a adesão às atividades propostas. Mais ainda, foi necessário trazê-los à cena e conhecê-los um pouco melhor, para apontar resultados possíveis dessa experiência.

Ainda no capítulo 1 foram descritas as relações entre a professora, os alunos, a escola e o material didático e algumas impressões sobre o relacionamento do público de cada uma destas instituições com a cultura extra escolar. Alguns temas descritos foram explorados em análises específicas e submetidos à literatura apropriada.

No capítulo 2 busquei refletir, diante da apresentação da experiência didática, sobre o ofício do historiador, o currículo de História e o modo pelo qual isso irrompe em uma complexa sobreposição de discursos na sala de aula. As considerações não se propuseram a visitar longa bibliografia, mas sim localizar a dinâmica que nessas escolas onde o trabalho se desenvolveu mantêm frente a esses elementos.

O professor de História assume seu papel na veiculação de um determinado discurso sobre o passado, mas o faz juntamente com outras narrativas, como aquelas veiculadas pela mídia - com destaque ao cinema - e pelo livro didático. Os objetivos atribuídos ao ensino de História favoreceram a localização do presente trabalho frente às 
propostas de encaminhamento em sala de aula. Foi necessário explicitar não somente o que se pretende com o ensino desta disciplina, mas também qual a História que deve ser ensinada. Para este debate foram chamados historiadores como Carlos Alberto Vesentini $(1984,1997)$ e Adalberto Marson (1984), dentre outros. Ambos contribuíram com a análise de uma memória sobre o ensino, a qual é gerada pelos historiadores e alimentada por meio do ensino.

O terceiro capítulo é dedicado às aproximações entre o cinema e a História. No início há um breve histórico do cinema e principalmente suas características constitutivas, ou seja, aquelas que serão caras às análises. No caso desta pesquisa, a técnica cinematográfica é fundamental para análises tanto dos filmes assistidos em aula quanto daqueles produzidos pelos alunos. Para essa tarefa foram chamados alguns estudiosos do cinema e de sua estética, tais como Ismail Xavier (1978, 2003a, 2003b, 2008) - cuja produção merece destaque devido à profundidade com que aborda o tema - e Jean-Claude Carrière (2006), entre outros.

A presença dos estudos de Marc Ferro (1992) sobre o cinema - como documento material de uma época, divulgador de uma ideologia, necessariamente decodificável ao historiador - foi muito pertinente. No entanto, mereceu um contraponto, a partir da produção do professor Eduardo Morettin (2008), o qual explora o cinema juntamente com seu conteúdo histórico, como uma forma privilegiada de informações e comunicação, ampliando o horizonte teórico acerca da aproximação entre ele e a História.

Para a abordagem especifica do uso do cinema na sala de aula, recorri a obras dos autores Circe Bittencourt (2004), Elias Tomé Saliba (1993, 2004, 2007) e Marcos Napolitano. Cada um, a seu modo, analisa o filme sob o ponto de vista histórico, com pequenas considerações sobre a forma específica e a constituição de um discurso. Localizo, nesse capítulo, a experiência realizada com o cinema-objeto e a sua modalidade discursiva.

O quarto capítulo é dedicado à análise dos filmes produzidos pelos alunos. As obras estão contidas em duas amostras, correspondentes às produções dos anos de 2007 e 2008, totalizando 13 filmes, todos eles trabalhando com a mesma temporalidade histórica, no período do governo de Getúlio Vargas.

Com o objetivo de fazer esta reflexão sobre os filmes, como um exercício de produção discente, concentrei-me na avaliação da forma utilizada pelos alunos para construir sua mensagem, avaliando cenário, personagens, trilha sonora, cores e símbolos mobilizados. Esses elementos foram avaliados tanto isoladamente quanto por meio de comparações.

A invenção do possível, no capítulo 5, é um balanço dos resultados obtidos a partir da experiência pedagógica, tanto nas considerações do Caderno de Campo, quanto nos 13 filmes produzidos pelos alunos. Há ainda uma avaliação dos caminhos e das escolhas 
realizadas em cada etapa da produção, e também a submissão a uma investigação teórica, colocando-os à prova diante dos objetivos do exercício. Todo esse trabalho foi realizado em uma dupla dimensão, ou seja, há que se falar das possibilidades encontradas no relato de experiência e nos filmes produzidos. Possibilidades interpretativas e de apontamentos para novas configurações em trabalhos futuros também foram registradas. Dito de outro modo, avaliar os resultados do trabalho é dar-se conta dos seus limites.

Ao escolher organizar o curso de História a partir de uma linguagem realizei uma aposta no potencial de comunicação do cinema. Também pretendia explorar sua relação com o conhecimento e a produção do saber histórico, de modo que esse recurso tornou-se objeto de estudo e modalidade discursiva. Este imbricamento de significações foi verificado nas produções fílmicas ao longo dos dois anos desta pesquisa.

É curiosa a percepção de que, enquanto construção de um discurso, o enredo tende a reiterar uma argumentação sobre a História presente na memória escolar. No entanto, com a transposição dessa narrativa para uma composição de filme, o sentido ganha amplitude. De modo geral, a trama construída confirma um discurso das classes dominantes acerca do governo de Getúlio Vargas, mas na imagem há elementos que oferecem ao espectador atento algumas pistas de uma elaboração.

O fato de o trabalho final ser veiculado a outros alunos conferiu à composição da obra uma atenção à intelegibilidade, ou seja, os grupos recorreram a símbolos e temas que seriam de fácil entendimento para os demais espectadores. Desse modo, também trouxeram à cena representações sobre sua faixa etária, origem social e também a referência a certo modo de ler a História. Até mesmo uma relação irônica com o conhecimento pode ser estabelecida, uma vez que os grupos produziram obras de ficção ao mesmo tempo em que debruçaram-se sobre o passado, e para isso recorreram ao domínio de conhecimento extra-escolar referente à cultura midiática.

Aqui os resultados se direcionam a um exercício de saber, de um modo específico de aproximação com o conhecimento histórico, bem como à percepção de que a escola não é a única portadora de discursos sobre as ações dos homens no tempo. Antes ela deve ser capaz de dialogar com as representações que chegam, que mesmo diante de um currículo que se pretende hermético, escapam e dotam de sentido o presente.

Talvez o exercício proposto se dedicasse à reconstrução da experiência em que a sugestão, a intelectualização, a hipótese, o raciocínio e a verificação estreitassem as distâncias entre a vida que os alunos conhecem e a realidade oferecida na sala de aula. É uma das tarefas 
do ensino de História auxiliar o educando na decodificação do mundo, mas não aquele que ficou no passado coberto de pó; antes este que chega à porta e entra pela tela do computador.

Pode-se comparar a diferença entre o ponto de vista lógico e psicológico com a diferença que existe entre as notas que um explorador toma em um país desconhecido, onde tente descobrir e traçar um caminho, e o mapa perfeito e acabado que se constrói depois que a região tenha sido definitivamente explorada. Os dois são mutuamente dependentes. Sem a marcha tortuosa e incerta do explorador, não se poderiam colher os fatos necessários para o levantamento completo do mapa (DEWEY $\mathbf{1}$ apud BOTO, 2006, p. 1).

1 DEWEY, J. Vida e Educação. Rio de Janeiro: Editora Nacional, s/d. 


\section{Capítulo 1 A EXPERIÊNCIA PEDAGÓGICA}

Os objetos analisados neste trabalho nasceram de uma experiência pedagógica, isto é, em uma atividade desenvolvida nas aulas de História. Essa atividade, que será aqui descrita, não se presta a apontar um caminho. Antes, trata-se de uma proposta que foi submetida à reflexão. Descrevem-se fatos e levantam-se possibilidades - e não prescrições -, que ocupam um lugar específico em seu campo, com limites e comunicações com um dado habitus.

O trabalho empírico ofereceu duas modalidades de objetos para serem problematizados. O primeiro deles são filmes produzidos por alunos do $9^{0}$ ano do Ensino Fundamental para as aulas de História, como trabalho escolar de adesão livre. O material foi gerado ao longo de atividades desenvolvidas durante os anos letivos de 2007 e 2008 . O segundo objeto é um caderno de registros no qual realizei, em 2008, anotações referentes ao processo de elaboração dos filmes, algumas impressões e falas dos alunos. Portanto, nesse conjunto, há um objeto produzido pelos alunos - os filmes, ainda que eu tenha coordenado sua produção - e um outro produzido por mim - o caderno de campo -, a partir de meu crivo pessoal, constituído de registros de caráter etnográfico.

Com o objetivo de oferecer ao exercício certa racionalidade há uma descrição do processo em que ambos os objetos foram produzidos. É importante observar que meu envolvimento tanto como professora que desenvolveu o projeto quanto como pesquisadora que problematiza e aponta limites para os resultados impede que haja neutralidade nas análises. A explicitação do modo de produção constará do relato de experiência.

\subsection{A coleta de dados e o caderno de campo}

Os objetos empíricos de análise para este trabalho foram não somente os filmes produzidos pelos alunos, mas também o caderno de registros de suporte - aqui denominado Caderno de Campo. Este último teve como objetivo o registro de um conjunto de descrições pertinentes às atividades realizadas acerca da preparação dos filmes e do impacto das atividades de sensibilização do olhar junto aos alunos.

Somente houve registro no caderno de campo em 2008, já que, no ano anterior, não tive essa atenção. Neste trabalho, eles são utilizados como parte integrante do texto, 
referenciados com as iniciais CC - Caderno de Campo -, entre parênteses, sempre que se fizer menção a eles.

Os registros realizados nesse caderno ocorreram de modo a contemplar as atividades que compunham, bimestralmente, os núcleos do projeto. Estes eram constituídos por exercícios de análise de filmes previamente selecionados. Anotaram-se as falas dos alunos consideradas relevantes. É certo que os critérios para essa seleção foram subjetivo; pode-se dizer que tenham sido influenciados pela expressividade na manifestação de opiniões minhas e dos alunos - ou por conterem informações de interesse para o projeto.

Em certos momentos registrei a presença de determinadas representações dos alunos sobre a História. Estas se explicitavam durante as aulas ou quando analisávamos uma imagem ou texto. Recordo que um dos objetivos desta pesquisa foi verificar as representações que os alunos possuem sobre o ensino de História e os efeitos que a compreensão de elementos fílmicos na composição de uma determinada narrativa pode oferecer à aprendizagem.

Sem a preocupação com a filiação imediata às propostas da etnografia, os registros desenvolvidos seguiram a tentativa de descrição da cultura uma vez que:

O etnógrafo encontra-se, assim, diante de diferentes formas de interpretações da vida, formas de compreensão do senso comum, significados variados atribuídos pelos participantes às suas experiências e vivências e tenta mostrar esses significados múltiplos ao leitor. (ANDRÉ, 2008, p. 20).

No entanto, a utilidade que se dá aos princípios etnográficos em educação não segue a modalidade dos etnógrafos. Trata-se, antes, de uma adaptação da etnografia à educação. Aqui "o pesquisador tem sempre um grau de interação com a situação estudada, afetando-se e sendo afetado por ela" (ANDRÉ, 2008, p.28). O princípio foi respeitado, meu envolvimento com a proposta tendo gerado uma variação dessa descrição denominada estudo de tipo etnográfico. Convém destacar que nessa modalidade de registro fui o principal agente de coleta dos dados. Realizarei a análise contando com ênfase narrativa no processo, para avaliação posterior dos resultados.

Considero que não há objeto externo ao sujeito, tampouco ao pesquisador, de modo que a suposta neutralidade deve ser substituída por rigor. A principal preocupação é com o significado que têm as ações e os eventos para as pessoas ou os grupos estudados. Alguns desses significados são diretamente expressos pela linguagem - tanto a dos alunos, verificada em suas falas, quanto a usada por mim no registro. Outros são transmitidos indiretamente, por meio de suas ações ou até mesmo de suas produções. 
Os registros foram feitos em momentos diferentes daqueles em que as atividades se desenvolveram - na maioria das vezes, no mesmo dia de realização das atividades. Nessas anotações procurei enfatizar a proposta que realizei e as reações dos alunos. Dessa forma, ao fazer as anotações, também fazia um balanço do trabalho, inclusive desses registros. Isto oferecia a possibilidade de alteração no andamento das atividades para as turmas que ainda não estavam no mesmo estágio do projeto.

A realização do registro da pesquisa em momento posterior à aula possibilitava uma espécie de esfriamento da situação, o que favorecia o distanciamento. Isto porém não significa neutralidade, mas certa racionalidade na elaboração do material.

Fica ainda a certeza de não ter sido registrado tudo o que ocorreu - a atividade de registro não implica reprodução de sujeitos e papéis, mas efetiva-se a partir de uma seleção, sob o olhar do pesquisador. Os resultados conquistados no ano de 2007, ainda que não tenham sido registrados, favoreceram os registros de 2008 - enquanto realizava as análises, fazia também comparações com o ano anterior; a experiência de um ano antes também ofereceu parâmetros para selecionar aquilo que seria anotado.

Outro objetivo primordial do Caderno de Campo foi manter certa fidelidade à proposta inicial da experiência pedagógica. Devido ao fato de o trabalho ter como foco uma atividade que se desenvolve ao longo de todo o ano letivo, era necessário manter a coerência dos registros durante esse período.

As informações contidas nesse caderno serviram, a princípio, para subsidiar o Relato de Experiência. Ou seja, as narrações, análises e falas foram usadas nesta dissertação como elemento de análise das atividades desenvolvidas ao longo do ano de 2008.

\subsection{As escolas: uma apresentação}

As portas são inumeráveis, a saída é uma só, mas as possibilidades de saída são tão numerosas quanto as portas (KAFKA apud SEVCENKO, 2007, p. 7).

O projeto de pesquisa de que trata a presente dissertação foi desenvolvido em duas escolas da rede particular de ensino da capital paulista. Ambas são confessionais, ligadas a uma ordem de religiosas católicas com sede na Europa, fundada no final do século XIX, que é mantenedora e beneficiária dos recursos econômicos gerados com essa atividade. 
A organização administrativa das escolas é centralizada, exercida por uma religiosa que dirige todas as cinco escolas do grupo. Ela conta ainda com o apoio de um conjunto de coordenadoras, tanto pedagógicas quanto educacionais, para a administração.

Dessas cinco unidades escolares, três localizam-se na capital e outras duas no interior. Todas seguem a mesma administração e planejamento de atividades. Ao longo do presente trabalho, para citar cada uma das escolas onde se desenvolveu este projeto, a referência será por meio das letras $A$ e $B$.

Todas as escolas do grupo adotam a divisão bimestral do ano letivo e utilizam material didático próprio - editado também por sua própria editora -, desde a Educação Infantil até o $9^{0}$ ano do Ensino Fundamental. O sistema de avaliação bimestral tem três componentes: uma primeira prova, com 10 exercícios dissertativos, uma segunda prova, com 10 exercícios objetivos, e um terceiro conceito chamado de avaliação formativa, composto por 10 pontos, dos quais 4 podem sofrer desconto de ordem disciplinar - 0,5 ponto a cada infração que os alunos cometem, como não execução da tarefa de casa, falta de material, indisciplina em sala de aula e atrasos - e os demais 6 pontos são atribuídos a partir de atividades criadas pelo professor. Desse modo, a nota bimestral é uma média simples entre as três avaliações, sendo necessário nota 5, em cada bimestre - ou o equivalente anual de 20 pontos -, para a aprovação do aluno.

Todo o conteúdo trabalhado no bimestre é cobrado nas duas provas. Para sua composição, em cada série, cada professor, seguindo os temas predeterminados no cronograma das aulas, envia determinado número de exercícios para uma coordenação, que os seleciona e monta a prova que será aplicada aos alunos. Os professores não têm acesso a essa configuração final da prova até o dia em que ela é aplicada.

Como a autonomia para a montagem da prova fica por conta dessa coordenação, a seleção dos conteúdos nas aulas torna-se uma tarefa complexa, uma vez que não é possível, de antemão, ter conhecimento dos temas específicos que serão abrangidos pela avaliação. Deste modo, cria-se um clima de ter que ensinar tudo. A prova acaba sendo uma surpresa tanto para os alunos quanto para os professores. Outro efeito é a possibilidade de que os itens mais explorados em aula não sejam cobrados em prova. Para que esses efeitos possam ser minimizados e não sejam refletidos nas notas finais, os critérios de correção ficam por conta do professor da turma. De alguma forma a prova avalia tanto os alunos quanto o professor.

Em relação ao trabalho da coordenação das escolas, há formalmente uma sensível diferença entre as atribuições da coordenadora educacional e da pedagógica. A primeira seria responsável por manter o cumprimento das regras preestabelecidas, particularmente naquilo 
que tange à disciplina dos alunos, punições e repercussões diante dos seus responsáveis. Para a segunda, ficaria a responsabilidade pelo funcionamento das atividades educativas, com destaque às avaliações, controle de faltas de professores e outros temas específicos que a escola desenvolve naquele ano. Cumpre notar, porém, que na prática escolar cotidiana não há uma fronteira rigorosa entre essas duas coordenações.

A organização das aulas, em cada disciplina, deve cumprir algumas exigências administrativas: para desenvolver o conteúdo, cada professor deve obedecer a um cronograma previamente estabelecido no ano anterior, por um dos professores da série. Este traz uma divisão semanal das atividades ao longo do ano, com a delimitação de páginas e temas que devem ser seguidos, bem como dos conteúdos a serem cobrados nas provas e na recuperação final. Ao longo do bimestre, a coordenação vista o material escolar ou o próprio caderno dos alunos e confere a adequação à distribuição de conteúdos já realizada.

Soma-se a essa organização geral o fato de que cada professor deve elaborar o chamado plano de aula, uma apresentação de como a aula será desenvolvida. Deve ser detalhado em um formulário específico, onde devem constar os objetivos do capítulo, o quadro sinótico que será desenvolvido com os alunos e as tarefas que serão feitas no processo de avaliação. Não há um momento em especial para discussão de sugestões de atividades ou de provas, bem como para comentários referentes aos planos de aula entregues.

Toda essa lógica resulta na construção de um determinado espaço escolar em que a reprodução de conteúdos é apresentada como uma possibilidade de ordem e a viabilização de um conjunto de articulações burocráticas. Também corrobora para esse sentido de permanência de organização de cronograma de trabalho ou de atividades propostas a necessidade de uma unicidade de procedimento capaz de congregar as cinco escolas que compõem o sistema. Nesse sentido, há pouco espaço para a elaboração de propostas em que a reflexão seja privilegiada no planejamento, o ensino efetiva-se na esteira da ilusão da certeza inabalável do currículo, a partir do domínio das regras de um saber assumidas aqui como leis.

A análise desta experiência pedagógica pode talvez nos auxiliar na reflexão de outras possibilidades de construção do sentido do saber em que a certeza não fique no centro, ou seja, operar nas brechas de um direcionamento sofisticado, em que a dúvida lançada pode ser um elemento de crítica - entende-se dúvida aqui não como a simples contestação de determinada tradição, mas como um ponto de partida para explicitar o processo de construção do conhecimento e a hipótese argumentativa de um conjunto de saberes. Trata-se de verificar as possibilidades pedagógicas de um exercício realizado, sem proposições. 
Há um importante esclarecimento a respeito desse sentido condutivo da dúvida, dado por Ferrara:

A dúvida, como superação do pensamento conceitual, desestabiliza o saber, e com ele a instituição e sua prática consagrada: o ensino. O aparecimento da dúvida substitui o ensino pelo aprender e a sala de aula pelo laboratório, pela experimentação de ideias e ações. Substituir o ensinar pelo aprender é o que a instituição, a escola, a universidade não podem suportar porque isso as desestrutura, ou seja, põe a nu suas fissuras, falhas ou contradições. A instituição do ensino é o espaço linear da igualdade, não pode conviver com o pensamento original, com a invenção, em que encontram espaços as peculiaridades e as assimetrias.

Na dúvida só a experiência ensina, e seu instrumento é a inferência, a vontade de aprender (FERRARA, 1993, p. 124).

\subsection{Os alunos: um breve perfil}

Ce vê né, professora: quem lembra de colégio particular? Todo mundo pensa que a gente é riquinho... Assim é melhor estudar na escola pública. Lá pelo menos a gente ganha coisa, aqui a gente paga tudo (CC)

Os alunos de cada uma das escolas possuem distinções; o simples fato de pertencerem à rede particular de ensino não nos fornece deles um perfil único. Deste modo, diante das especificidades da condição de sujeitos sociais inseridos em um determinado contexto da cultura escolar, apresento a seguir alguns elementos com o objetivo de caracterizá-los, isto é, identificar quem são os agentes que estabeleceram, a partir desta experiência, uma determinada relação com o saber e como esta pode ser construída tendo, ao mesmo tempo a marca da origem social e não sendo determinada por ela (CHARLOT, 2001).

Os alunos que participaram das atividades do projeto foram os do $9^{-}$ano do Ensino Fundamental das escolas $A$ e $B$ nos anos de 2007 e 2008. Na tentativa de caracterizálos quanto à sua posição diante do saber, farei considerações a respeito do meio social e cultural onde vivem, sua origem e pretensões sociais, seus padrões de consumo, suas expectativas com relação aos estudos, bem como alguns aspectos organizacionais da escola onde estudam.

A escola $A$ está localizada em um bairro em que há crescimento imobiliário, com a instalação de condomínios de alto padrão, atraindo para a região um público em ascensão econômica. É certo que há outras opções de escola no bairro, mas esta se anuncia - como tantas outras - como uma instituição em que o conhecimento e a tecnologia se encontram. $\mathrm{O}$ 
número de alunos matriculados nos anos de 2007 e 2008 aproximou-se de 3000, do Ensino Infantil ao Médio.

Com a expansão imobiliária há também um incremento na instalação e diversificação dos serviços oferecidos na região. Os alunos apresentam hábitos de consumo variados e caros, incluindo viagens de intercâmbio para estudo de línguas e passeios para a Disney. A proximidade física com os três shoppings da região oferece acesso a cinema, em particular a produções norte-americanas veiculadas em grandes redes de entretenimento, que frequentam semanalmente, e a jogos de diversão eletrônica.

O padrão de consumo também pode ser verificado a partir da variedade de modelos e marcas originais de tênis que usam - ainda que a maior parte deles possua dispensa médica das atividades de Educação Física, de modo que estes tornam-se um artigo de hierarquização. Essa tradição da estetização de determinados itens usados pelos alunos nem sempre se confirma com os gastos e a importância que dedicam aos materiais didáticos, uma vez que alguns deles não adquirem os livros indicados pela escola. Os itens de papelaria, os quais podem oferecer maior sinal de distinção, variam na qualidade e na diversidade, destacando-se fichários e folhas de blocos com personagens do universo teen, além de canetas coloridas importadas. Todos esses objetos são guardados em mochilas que estampam marcas mundiais, tais como Puma, Nike, Adidas, entre outras 2.

A expectativa que possuem diante dos estudos também é variável, havendo, no entanto, uma fala comum, devido às condições materiais e ao poder aquisitivo que possuem. Não se verifica uma identificação do nível de instrução como um meio de ascensão social, mas de manutenção de um patrimônio que a família já possui.

De acordo com suas diversas origens familiares, é possível inferir a existência de alguns cenários profissionais possíveis. O primeiro é a sucessão na atividade de gerência de um pequeno comércio que se expandiu, mesmo sem grande instrução dos pais - alguns alunos chegam até mesmo a trabalhar com os pais nas férias. A segunda é a possibilidade de assumirem um emprego no escritório dos pais, sendo explicitada a necessidade de seguir o mesmo curso superior, sem tanta preocupação com a universidade em que se fará a graduação. Uma terceira possibilidade é aquela de seguir uma carreira distinta dos pais, pensando inclusive em superá-los profissionalmente, até mesmo ingressando em uma universidade de maior prestígio.

\footnotetext{
2 É certo que nem todos os alunos possuem esses materiais, não se pode indicar $100 \%$ de adesão a essa estetização. No entanto, trata-se de uma grande maioria.
} 
Também é na escola $A$ que está matriculado o maior número de alunos, em relação às demais escolas da rede. Desse modo, a distribuição das turmas pelos espaços físicos também é significativa: os alunos do $9^{-}$ano do Ensino Fundamental ao $3^{-}$ano do Ensino Médio ficam em um mesmo prédio, enquanto os demais, até o $8^{\underline{0}}$ ano do Ensino Fundamental, ficam em outro prédio. A desterritorialização dos alunos que chegam ao $9^{\underline{0}}$ ano provoca uma rápida adesão à estetização de certas posturas do Ensino Médio, talvez adiantando determinados hábitos.

No ano de 2007, data do início do projeto, a escola $A$ seguia a organização de turmas homogêneas, em que os alunos de cada sala eram previamente selecionados e agrupados a partir de seu desempenho - mensurado em notas nas áreas de Língua Portuguesa e Matemática - no ano anterior. Dessa forma, das quatro turmas formadas no $9^{\circ}$ ano, uma delas era considerada a mais forte, outra com alunos esforçados, e as demais eram problemáticas $^{3}$ - tanto na questão pedagógica quanto na disciplinar. Ainda com todas essas diferenças, as turmas eram submetidas ao mesmo sistema de avaliação, com suas provas e atividades.

Este critério de organização das turmas foi alterado em 2008, motivado pelo grande número de ocorrências disciplinares e transferências de alguns alunos para outras escolas.

No início do ano, as escolas entregam a cada aluno um kit pedagógico contendo um bloco de papel timbrado para a realização de atividades, juntamente com dois lápis, régua e uma agenda. Todos esses materiais possuem a identificação do Sistema e não são utilizados pelos alunos na escola $A$. É comum, inclusive, encontrá-los no lixo ou despedaçados pela sala, ou seja, os alunos possuírem sua própria agenda e suas folhas parece indiciar uma negação da instituição ou pode ser uma simples estetização do seu material escolar.

A escola $B$ fica na região central da cidade. Seu público possui um poder aquisitivo menor em relação à escola $A$ e as mensalidades cobradas são as de menor valor em relação às demais unidades do Sistema. Nos anos em que o projeto se desenvolveu na escola havia aproximadamente 750 alunos matriculados.

A região em que a escola $B$ se localiza passa um momento de arrefecimento imobiliário, contando com condomínios antigos e casas populares. Não se registra nenhum empreendimento grande ou de alto padrão. Também não há nenhuma outra escola da

\footnotetext{
3 Os adjetivos associados a cada uma das turmas surgem de uma explicitação das falas dos professores que lá lecionavam, inclusive confirmadas pela coordenação.
} 
iniciativa privada que supra toda a educação básica particular na região, de modo que não ocorre disputa tão acentuada, tal como existe na região da escola $A$.

A vizinhança é fecunda, porém, culturalmente, contando com salas de teatros, restaurantes típicos tradicionais e até mesmo escola de samba, além de sediar uma tradicional festa de rua. É certo que tal presença favorece a participação dos alunos em algumas dessas atividades, propiciando uma experiência distinta daqueles da escola $A$, inclusive trazendo um caráter maior de socialização e coletivização.

Outra característica a ser destacada se refere à estetização do uniforme escolar: a maior parte dos alunos da escola $B$ usa um mesmo modelo de tênis, de uma determinada marca, apenas com variações de cores. Objetos de papelaria também podem indicar um menor poder aquisitivo - veem-se canetas Bic. Também se observa o uso de um caderno único para todas as matérias, ou usam folhas de fichário simples. Poucos são aqueles que possuem um fichário de personagens do universo teen. As mochilas não estampam marcas ou grifes de prestígio, ou são de marcas consagradas, porém, não originais, de acordo com o depoimento deles próprios.

No caso da escola $B$, devido ao pequeno número de salas, não foi adotado o critério de homogeneidade - adotado na escola $A$ - para montar as turmas.

O kit pedagógico fornecido pelas escolas no início do ano, diferentemente da escola $A$, é usado com frequiência pelos alunos da escola $B$. O simples uso desse material pode indicar uma melhor utilização dos recursos econômicos que os pais investem na escola $B$.

$\mathrm{Na}$ origem econômica das famílias dos alunos na escola $B$ verificam-se pequenos comerciantes com estabelecimentos na região, costureiras e outros profissionais ligados aos teatros ou restaurantes das proximidades, profissionais liberais - em particular advogados - e ainda enfermeiros - há grandes hospitais, públicos e particulares, na região - ou profissionais com formação técnica, assalariados.

A expectativa que os alunos revelam em relação ao saber em seus discursos assemelha-se àquela também manifestada na escola $A$ : a manutenção do poder aquisitivo e a gestão dos negócios dos pais. No entanto, é possível verificar uma variação: a expectativa de ascensão social, ou seja, há aqueles alunos que se beneficiam dos estudos também como um instrumento para alcançar um crescimento do poder aquisitivo, possibilidade esta identificada com a realização de um curso superior, tanto em uma instituição particular quanto pública. É comum os alunos da escola $B$ que concluem o Ensino Fundamental deixarem a instituição em busca de um curso técnico e ingressarem no mercado de trabalho, situação que pouco ocorre na escola $A$. 
O espaço escolar também oferece alguns arranjos distintos em relação à outra escola. Com poucas salas de cada turma, os intervalos ocorrem reunindo alunos do $6^{\circ}$ ano do Ensino Fundamental ao $3^{\underline{0}}$ ano do Ensino Médio. As relações estudantis atravessam as faixas etárias e as séries. Ainda que com núcleos de atividades e grupos distintos, é comum eles se tratarem pelo nome, indiciando algum nível de amizade entre eles.

\subsection{Relato de experiência: atividades desenvolvidas em 2007 e 2008}

“- Cheguei na USP antes da minha irmã.

- A senhora quer levar meu filme lá pra USP? E eles se interessam por isso lá?"'(CC)

O sentido descritivo deste relato é o de situar o leitor no processo de pesquisa. $\mathrm{O}$ objeto tratado não é apenas a experiência pedagógica. Esta gerou as fontes que serão analisadas neste trabalho, que são: um conjunto de filmes produzidos pelos alunos em 2007 e 2008 e o Caderno de Campo, resultado de registros das atividades desenvolvidas ao longo de 2008.

A proposta foi desenvolver ao longo do ano uma sequência programada de atividades em que a linguagem do cinema fosse privilegiada, tanto como material de análise portador de um determinado discurso histórico - como modalidade de autoria discente. $\mathrm{O}$ objetivo era propor um sentido para o curso de História do $9^{\circ}$ ano, calcado em uma linguagem específica e não exatamente em um eixo temático ou ainda em uma racionalidade criada a partir da apresentação de fatos em ordem cronológica.

Visando introduzir aos alunos este projeto e posteriormente subsidiar a sua realização, a cada bimestre um filme específico foi estudado. A seleção dos títulos desses filmes obedeceu à lógica de temas e conteúdos trazidos na apostila. Outro critério utilizado foi o de serem filmes que os alunos - de acordo com o perfil do grupo, caracterizado na apresentação do público - normalmente não assistiriam em casa.

Na tabela 1 são mostradas as atividades desenvolvidas ao longo dos anos letivos de 2007 e 2008, em cada bimestre. Em ambos os anos a estrutura central do projeto foi mantida inalterada.

Todas essas atividades foram conciliadas, dentro do cronograma da escola, com os conteúdos e atividades pré-estabelecidos. Em geral, o desenvolvimento das aulas conta com a exposição docente, construção de esquemas explicativos em lousa, pequenas leituras da 
apostila, análise oral de imagens do material didático, realização de exercícios e provas. Há, portanto, pouco espaço para exercícios de autoria discente; o professor e o material didático oferecem o conjunto de informações que os alunos devem conhecer. Devido à grande quantidade de tarefas que devem ser cumpridas ao longo de um bimestre, fiz a opção por realizá-las em um período menor de tempo para que restassem aulas para a realização dos exercícios com os filmes. Algumas atividades foram subtraídas, tais como alguns estudos dirigidos propostos no material didático.

Tabela 1 - Atividades realizadas nos anos letivos de 2007 e 2008.

\begin{tabular}{|c|c|c|c|}
\hline Bimestre & Filme & Atividades Realizadas & $\begin{array}{l}\text { Etapa de trabalho para aqueles } \\
\text { que participaram do projeto }\end{array}$ \\
\hline $1^{\underline{0}}$ & $\begin{array}{l}\text { O Auto da } \\
\text { Compadecida } 4\end{array}$ & $\begin{array}{l}\text { Análise do filme inteiro por } \\
\text { meio de relatório escrito. } \\
\text { Apresentação do projeto, } \\
\text { convite e adesão. }\end{array}$ & $\begin{array}{l}\text { Adesão por escrito ao projeto, } \\
\text { formação dos grupos e ciência } \\
\text { das atividades a serem } \\
\text { desenvolvidas em cada } \\
\text { bimestre. Pesquisa sobre o } \\
\text { governo brasileiro das décadas } \\
\text { de } 1930 \text { a } 1950 \text {. }\end{array}$ \\
\hline $2^{\underline{o}}$ & $\begin{array}{l}\text { O Grande } \\
\text { Ditador }^{5}\end{array}$ & $\begin{array}{l}\text { Análise de trechos do filme } \\
\text { por meio de relatório escrito. }\end{array}$ & $\begin{array}{l}\text { Elaboração de um projeto do } \\
\text { filme: escolha da temática, } \\
\text { proposição de cenário e } \\
\text { personagens. }\end{array}$ \\
\hline $\mathbf{3}^{\mathbf{0}}$ & $\begin{array}{l}\text { Gen pés } \\
\text { descalços } 6\end{array}$ & $\begin{array}{l}\text { Análise de trechos do anime } \\
\text { por meio de relatório escrito } \\
\text { em aula. }\end{array}$ & $\begin{array}{l}\text { Confecção de cenários e } \\
\text { personagens. Captura de um } \\
\text { conjunto aproximado de } 300 \\
\text { fotos referentes à sequência do } \\
\text { filme, entrega das imagens em } \\
\text { CD. }\end{array}$ \\
\hline
\end{tabular}

4 O AUTO DA COMPADECIDA. Direção: Guel Arraes. Produção: Daniel Filho e Guel Arraes. Brasil: Globo Filmes, 2000. 1 DVD (104 min), PAL-M, color., estéreo.

5 O GRANDE DITADOR (THE GREAT DICTATOR). Direção: Charles Chaplin. Produção: Charles Chaplin. Estados Unidos: 1940. 1 DVD (124 min), PAL-M, p\&b, estéreo.

6 GEN PÉS DESCALÇOS. Direção: Keiji Nakazawa. Japão: 1972. 1 DVD, PAL-M, color., estéreo. 
(continuação)

\begin{tabular}{l|lll}
\hline Bimestre & Filme & Atividades Realizadas & $\begin{array}{l}\text { Etapa de trabalho para aqueles } \\
\text { que participaram do projeto }\end{array}$ \\
\hline $4^{\underline{0}}$ & O ano em que & Análise do filme inteiro por & Montagem final da animação: \\
& meus pais saíram & meio de discussões em aula, & sequenciamento de imagens, \\
& de férias ${ }^{7}$ & sobre elementos da & inclusão do áudio e dos \\
& & linguagem fílmica. & créditos. Entrega do filme em \\
& & Apresentação e análise dos & CD. Veiculação no portal \\
& & filmes produzidos pelos & YouTube! \\
& & alunos. & \\
& & &
\end{tabular}

Em todos os filmes analisados, o objetivo foi destacar elementos específicos aos quais o público em geral não se atém. Pretendi demonstrar que uma linguagem necessita de determinadas habilidades para a análise e, no caso do cinema, há um conjunto de elementos singulares a serem explorados, tais como enquadramento da câmera, iluminação, cores, trilha sonora entre outros.

A técnica do enquadramento possibilita a identificação à qual já nos referimos como o efeito mais específico do cinema. A câmera olha para os outros personagens e para seus ambientes a partir dos olhos de um personagem. Ela pode olhar o ambiente a partir dos olhos de uma figura diferente a cada instante. Por meio de tais enquadramentos vemos o espaço da ação de seu interior, com os olhos dos dramatis personae, e sabemos como eles se sentem nele. O abismo no qual o herói despenca, se abre a nossos pés e as alturas que ele deve escalar se estendem para os céus diante de nossos olhos. (...)

$\mathrm{O}$ enquadramento e o ângulo podem fazer com que as coisas se tornem odiosas, adoráveis, aterradoras ou ridículas, à sua vontade (PUDOVKIN, 2003, p. 97-98).

No primeiro bimestre, o filme selecionado para a introdução da proposta de experiência foi $O$ Auto da Compadecida. Em 2007, os alunos assistiram ao filme como tarefa de casa e responderam a alguns exercícios, como em um roteiro de análise. A atividade correspondeu às aulas de toda a semana. A verificação dessas anotações se deu na sequência, com a veiculação e estudo do filme e roteiro em aulas. O filme era de fácil acesso para locação. Essa atividade contou com a adesão dos alunos, posto que a tarefa de casa é beneficiada com nota, no processo de avaliação da escola, e também por se tratar de uma modalidade diferente daqueles estudos dirigidos propostos normalmente.

7 O ANO EM QUE MEUS PAIS SAÍRAM DE FÉRIAS. Direção: Cao Hamburguer. Produção: Caio Gullane, Cao Hamburguer e Fabiano Gullane. Brasil: Globo Filmes, 2006. 1 DVD (110 min), PAL-M, color., estéreo. 
Já em 2008 essa atividade foi realizada em aula, pois sendo a primeira vez que eu lecionava para essa turma, preferi acompanhar toda a atividade. No caso dos alunos de 2007 já havia sido sua professora no ano anterior, quando realizamos atividades com filmes em que a História é o tema, tais como Elizabeth, a Rainha Virgem e O Patriota.

A temática do filme $O$ Auto da Compadecida corresponde ao estudo dos movimentos sociais ocorridos no Brasil durante a República Oligárquica, e em especial ao estudo do Cangaço. É certo que o título não ilustra o movimento social em particular, mas o chama à discussão.

Ao anunciar o título do filme, esperava que muitos já o tivessem assistido. Em 2007, isto se confirmou para cerca de $80 \%$ dos alunos. Em 2008, no entanto, fiquei surpresa ao constatar que os que já o haviam assistido não passavam de $30 \%$ na escola $A$ e $60 \%$ na escola $B$.

Nos dois anos, não houve nenhuma manifestação de restrição por parte dos alunos que já haviam assistido ao filme anteriormente. A atividade desenvolveu-se como se segue: o primeiro passo foi ler, na própria embalagem do filme, a ficha técnica, enquanto o DVD era preparado para a execução. Feito isto, a sessão foi iniciada, já tendo sido avisado a eles que não assistiriam ao filme inteiro, mas apenas a alguns trechos específicos.

Ao adiantar alguns capítulos houve, porém, reclamações. Quebrar a aparente linearidade do filme trouxe desconforto para alguns. Tendo planejado esse modo de apresentar o filme, já estava ciente dos protestos que surgiriam diante da seleção de cenas e, assim, o resultado foi evidente: ao final da sessão alguns alunos se queixaram:

“- A senhora bagunçou muito o filme, agora vou ter que alugar e assistir em casa pra entender direito.

- Por que não marca pra tarde? Todo mundo vem assistir." (CC)

Nesse processo de aula sobre o filme, há destaque para alguns detalhes ou elementos cênicos e técnicos que tendem a não perceberem. Desse modo, interrompo a sessão - em momentos nos quais conheço a duração do silêncio entre as falas, para não prejudicar o entendimento do áudio -, fazendo breves interferências ou lançando uma pergunta. Alguns alunos podem também formular questões ou responder algo que eu tenha perguntado anteriormente, enquanto o filme passa.

Respeitando as vicissitudes de cada turma e escola, realizo uma atividade padronizada, ou seja, procuro destacar os mesmos elementos. No caso particular de $O$ Auto da Compadecida, destaquei na sessão: 
- A composição do tempo da narrativa, ou seja, a aceleração dos diálogos a partir das falas, as cenas de destaque em câmera lenta, bem como seu efeito no enredo;

- O recurso da trilha sonora como elemento que indicia uma determinada situação na trama e o uso recorrente de vinhetas;

- O posicionamento da câmera no sentido de tomadas do alto e de baixo e sua relação com a posição social das personagens. Também o recurso da câmera para deixar personagens com diferentes alturas em um mesmo plano, indicando a participação de ambos em uma dada situação da trama - por exemplo, a personagem João Grilo (baixo) e Severino (alto).

- A construção das personagens, seus estereótipos, alimentados com humor, seus discursos e o significado metafórico de seus nomes - simples ou compostos, apelidos ou com sobrenome.

- A presença dos elementos divino e profano no desenvolvimento da trama.

- Os símbolos que compõem a visão de sertão, presentes no enredo.

Em 2008, na escola $B$, havíamos recebido uma nova aluna que chegara do interior de Maceió. Ela possuía um sotaque que suscitava risos na turma, até mesmo com um caráter depreciativo. Porém, durante a sessão, alguns alunos perdiam as falas das personagens devido à agilidade com que pronunciavam as palavras - e a aluna as recuperava com facilidade. Quando comentamos o filme, na aula seguinte, ela teve grande participação: realizou uma espécie de tradução do tipo do sertão - de acordo com a expressão que ela mesma usou. Contou-nos provérbios, algumas piadas e costumes, e também as histórias de Cangaço e coronéis que ouvira da boca de repentistas e em literatura de cordel que lera. A atenção que a turma lhe dedicou rendeu-lhe acolhimento.

Com o fim da sessão uma aluna falou: "Nunca pensei que um filme tão bobo pudesse mostrar tanta coisa". (CC)

Ainda em 2008, ao propor a leitura do roteiro de análise do filme para casa, e seu comentário na aula seguinte, houve a sugestão de uma aluna da escola $A$ para que ficasse como tarefa da semana assistir ao filme novamente em casa. É certo que a proposta parece encerrar uma tentativa de esticar o prazo de entrega das atividades, contudo, como se tratava de nosso primeiro exercício, e também por causa da quebra da linearidade da narrativa na exibição em sala, aceitei.

A figura 1 reproduz a proposta do roteiro encaminhado aos alunos. Cada uma das questões do roteiro foi devidamente comentada de modo a elucidar a proposta e para que os alunos conseguissem realizar a atividade. Existiram dúvidas nas respostas e na compreensão dos exercícios, gerando certa dificuldade em respondê-las. Alguma superação foi possível 
apenas com a interferência docente, com questões orais paralelas para esclarecer o enunciado, e evocando certo vocabulário. Como primeiro exercício, acredito que superestimei a capacidade de entendimento dos elementos do filme, pois os alunos tiveram dificuldades nas respostas escritas, mas participaram oralmente de modo ativo.

\section{$\underline{\text { Atividade Desenvolvida para análise do Filme O Auto da Compadecida }}$}

1. Organize $\mathbf{8}$ a ficha técnica do filme, contendo: título, ano, direção, roteiro/adaptação, estúdios, tempo de duração.

2. A morte e o enterro de uma cadela inauguram os conflitos do filme. Estes variam entre personagens o filme inteiro. Cite qual seria a natureza desses conflitos.

3. Analise quais relações poderiam explicar o fato de as personagens do "Coronel Antônio Moraes" e de "João Grilo" serem as únicas a possuírem nomes duplos no filme.

4. Faça uma breve apresentação de cada uma das personagens apresentadas no filme.

5. A presença do sexo feminino no filme circula em torno de polos: diferencie "Rosinha" (filha de Antonio Moraes) e "Dona Dora" (mulher do padeiro Eurico).

6. Compare o enredo construído no filme sobre a personagem Severino e as informações estudadas em sala de aula.

7. Comente a importância do uso do humor para sustentar o enredo do filme.

8. O "Julgamento" ocupa papel importante na trama do filme. Comente a acusação do Diabo e a defesa de Nossa Senhora da Compadecida para Severino e João Grilo.

9. Componha uma frase para explicar o enredo do filme.

10. Em sua análise, qual a personagem "mais esperta"? Justifique a sua escolha9.

Figura 1 - Roteiro de análise do filme $O$ Auto da Compadecida.

A leitura do filme deveria se ater a cada elemento constitutivo da arte cinematográfica, de modo que:

Deveria ainda dedicar-se às técnicas de sua produção, aos grupos sociais que interagem em sua elaboração, à política cultural, bem como às características gerais da sociedade que a produziu e, em certa medida, a consome. Como

\footnotetext{
8 Na composição das atividades realizadas pelos alunos da escola os professores devem usar como comando para os exercícios as chamadas habilidades de ensino, estas devem ainda ser apresentadas em negrito, por essa razão o modelo acima utilizado obedece a esses critérios.

9 Por falta de planejamento de minha parte, ou ainda porque não percebia a necessidade de ter ao menos um desses registros produzidos pelos alunos em mãos, não recolhi nenhuma atividade, permanecendo como tarefa de casa, registrada apenas no caderno. Concebi essa etapa como ponto de discussão, ou seja, uma atividade que seria ampliada contando com a participação das salas, as quais foram notadamente boas para exposições orais.
} 
um texto visual, o filme exige uma leitura interna particularizada de sua linguagem, mas também é uma produção cultural que possui sua própria história e de algum modo os alunos precisavam se aproximar dessa temática (BITTENCOURT, 2004).

Diante dessa primeira atividade de sensibilização do olhar, o modo de trabalharmos a linguagem fílmica foi explicitado - o filme deveria ser lido. A partir desse exercício convidei-os a participarem do projeto. Organizados em grupos de cinco a seis alunos, deveriam decidir se estavam interessados em produzir um filme sobre o período de governo do presidente Getúlio Vargas. Todas as turmas foram consultadas.

Propus um cronograma das atividades relacionadas à produção dos filmes, a serem desenvolvidas ao longo de todo o ano, fora dos horários de aula, organizadas bimestralmente, conforme mostrado na tabela $\mathrm{A}$, até que ao final do ano o resultado seria um trabalho de conclusão do Ensino Fundamental.

Devido ao fato de a escola não permitir atividades em grupo fora do horário de aula, propus uma divisão interna de trabalho: 2 alunos responsáveis pela pesquisa e roteiro, 2 para construir o cenário e 1 ou 2 para fazer as fotos e compor o formato final do filme. As notas seriam dadas para o grupo inteiro em cada bimestre - seria o equivalente a 4 pontos, dentre os 30 que podem somar ao longo do bimestre, com todas as avaliações.

Após uma semana, ocorreu a adesão dos grupos. De todo modo, a atividade era livre, ou seja, os alunos que não aceitassem participar do projeto realizariam outras atividades, com igual valor de nota. É certo ainda que o relacionamento dos alunos com a professora pode gerar algum apelo para os grupos aderirem, entretanto no início do ano essa relação geralmente ainda não é tão estreita. Em 2007, 9 grupos participaram o projeto, porém, apenas 7 deles entregaram o filme terminado. Ambos os desistentes abandonaram as atividades no $3^{\circ}$ bimestre, em um total de 5 turmas. Já em 2008 foram 7 os grupos que iniciaram o projeto e apenas um que desistiu, em um total de 6 turmas.

O princípio de uma proposta com adesão livre, merece aqui uma reflexão. Os alunos participariam, a partir do interesse pela proposta de trabalho, e não exatamente por se tratar de uma obrigação, ou merecer uma nota. Aqui convém uma avaliação com o auxílio de Bourdieu: é possível um ato desinteressado desses alunos diante do convite da professora? (BORDIEU, 1996)

É pertinente o fato de que os grupos de alunos que aderiram ao projeto, ainda que dois deles em cada ano tenham abandonando a finalização do filme, não apresentaram problemas de rendimento escolar e não necessitaram desses pontos para a sua aprovação, de modo que sua participação no trabalho não representou um benefício meramente quantitativo. 
Esses sujeitos do conhecimento integram o campo da educação e conhecem o funcionamento dos mecanismos que dão sentido à ação escolar, ou seja, possuem um conhecimento prévio, dissimulado ou não, daquilo que se pressupõe ser o perfil de um bom aluno. Esse também é um efeito do projeto ter sido aplicado ao público do $9^{0}$ ano: é longo seu percurso, e rica a construção de estratégias de sobrevivência na escola. Talvez, para alguns alunos para os quais o funcionamento da escola seja mais claro, a participação em todas as atividades seja pertinente.

Aqui a consciência desse lucro imediato do reconhecimento é questionada a partir da constituição do habitus, ou seja, de um conhecimento também pragmático, e que também é incorporado e, de tal modo, experienciado, que sua consciência é pretérita à ação, e se intensifica na adesão, atitude pela qual é sofisticada a participação. Nessa prática o pertencimento ao campo educacional é garantido ao aluno, pois ele torna visível o reconhecimento de regras específicas dessa lógica de posições. De outro modo, ao manifestarem o interesse pela atividade de produção do filme, alguns alunos comunicam que admitem uma das funções sociais da escola: o conhecimento, e sua dinâmica em um jogo que pressupõe regras de expressão. A dissimulação do lucro, uma vez que a questão das notas nem mesmo era cogitada nos diferentes bimestres, também confirma o caráter da ação discente: aprendi! É possível que essa consciência calculista mais ou menos cínica não seja clara.

Os agentes que lutam por objetivos definidos podem estar possuídos por esses objetivos. Podem estar prontos a morrer por esses objetivos, independentemente de qualquer consideração em relação aos lucros específicos, lucrativos, da carreira ou outros. Sua relação com o objeto que lhes interessa não é de modo nenhum o cálculo consciente de utilidade que lhe oferece o utilitarismo, filosofia que preferimos atribuir às ações dos outros. Ele tem o sentido do jogo; nos jogos no quais, por exemplo, é preciso mostrar "desinteresse" para ter êxito, eles podem realizar, de maneira espontaneamente desinteressada, ações que estejam de acordo com seus interesses (BOURDIEU, 1996, p. 146-147).

Um dos lucros obtidos pelos alunos que produziram os filmes foi a manifestação pública de um saber não conquistado diretamente na escola - o domínio da linguagem de software de animação e a sensibilidade para a produção de filmes; articularam um conjunto de informações verdadeiras no processo de comunicação com a narrativa do material didático, mas também manipularam-nas para construir um discurso de coerência interna, esboçando um exercício de autonomia tácita. Também houve o lucro do reconhecimento por outros sujeitos articulados nesse campo educacional, ou seja, suas produções seriam objeto de aula para outras salas, outra escola e estariam expostas no YouTube! - neste caso com um aval da 
professora e do saber do qual é portadora. Por fim, seriam objetos para uma pesquisa de mestrado na Universidade de São Paulo.

Nesse sentido, o ato desinteressado é expressão singular do reconhecimento, por parte dos alunos produtores dos filmes, do habitus que o acesso ao saber na escola constitui, e também reconhece sua dinâmica no momento da adesão, tornando público esse jogo de disputa por reconhecimento e acesso a melhores posições.

A execução do cronograma de trabalho - para aqueles que aderiram ao projeto ocorreu em paralelo às atividades de análise da linguagem fílmica, que envolveram todos os alunos. É certo que para aqueles que se dedicavam à montagem dos filmes essas atividades de análise possuíam outro significado. Os demais participaram e conheceram, em certa medida, o uso de uma linguagem como documento histórico - o cinema. Era necessário manter os alunos envolvidos, viabilizar a execução do projeto e ainda fazer com que os demais alunos acompanhassem o processo de realização do filme até as atividades do último bimestre, quando se tornaram expectadores críticos das obras.

Ainda no primeiro bimestre realizamos outra tarefa, antes de avançarmos no cronograma do projeto e introduzir os estudos sobre o próximo filme. Esta teve como objetivo exemplificar algumas características elementares da análise de outras linguagens, que não a escrita - um exercício de análise de imagens. Todos os alunos realizaram a atividade.

Nesse exercício, solicitado como tarefa para a aula seguinte, cada um dos alunos deveria trazer para a sala de aula uma imagem de guerra. Os únicos critérios estabelecidos foram o tamanho - no mínimo $1 \frac{1}{4}$ de folha de papel sulfite - e a necessidade de conter uma legenda que a identificasse. Por ocasião dessa proposta estávamos iniciando os estudos sobre a Primeira Guerra Mundial. É comum o grande interesse dos alunos por esse tema. Entendia que um exercício de análise de uma imagem também era uma sensibilização em relação à especificidade da linguagem com a qual estávamos trabalhando, ou seja, o cinema. Nesse sentido, trabalhar um quadro ou uma fotografia em particular pretendia oferecer uma atenção particular para o objeto, sem o envolvimento da trilha sonora e do movimento presentes no cinema. Era como compartimentar a análise para lhe oferecer atenção.

A partir dessas reflexões realizamos o exercício com as imagens que cada um trouxera de casa. Para o exercício, deveriam recortar a legenda e a conservar consigo, após trocar entre os colegas as imagens. Assim, cada um recebeu uma nova imagem e permaneceu com a legenda daquela que trouxera de casa.

De posse do documento, passei na lousa as questões a serem observadas e respondidas, como mostra a figura 2. 


\section{$\underline{\text { Roteiro para análise de Imagem de Guerra }}$}

1. Observe atentamente a imagem e descreva o que a caracteriza como uma imagem de guerra.

2. Sua imagem de guerra é uma ilustração ou uma fotografia? - Esse fato faz diferença na mensagem que a imagem transmite? - Justifique sua resposta.

3. É possível identificar quem é o autor da imagem? - Onde ele se encontra em relação à imagem?

4. Qual é a mensagem que a imagem transmite sobre a guerra?

Figura 2 - Roteiro de análise de imagem de guerra. (CC)

$\mathrm{Na}$ realização dessa atividade não foi necessária a minha interferência para esclarecimento da proposta. Talvez a atenção particular a um objeto em certa medida menos complexo que a peça cinematográfica viabilizou a compreensão dos alunos. Soma-se a isto o fato de serem poucos exercícios e serem desenvolvidos integralmente em aula.

Para exemplificar a proposta de cada questão usei uma imagem que constava na apostila e a li seguindo o roteiro, com a interferência de cada turma. $\mathrm{O}$ registro ficou como tarefa de classe e, portanto, nos cadernos, de modo que não possuo cópia escrita dos resultados. Cada aluno trabalhou com a imagem que trouxe. Em alguns casos, a caracterização da guerra correspondeu a cenas de pessoas mortas ou de uma explosão.

A percepção do cinema como fotografias em movimento produz uma especificidade analítica, porém o fato de os alunos de 2008 apresentarem certa dificuldade em acompanhar algumas características elementares da análise da imagem levou-me a propor um exercício com a imagem em si. Anteriormente, pretendia analisar uma imagem e depois ampliar essa percepção. As turmas de 2007 já haviam explorado, no ano anterior, oralmente, o tema de análise de imagens.

Como princípios teóricos para análise de fotografias nas aulas de História, segui os apontados por Bittencourt (2004), em particular a compreensão de que a fotografia é uma representação do real e de que a sua crescente visualização na vida cotidiana é capaz de produzir no espectador certa perda de sensibilidade do olhar.

A pesquisadora esclarece:

É sempre necessário perguntar o que está sendo fotografado, a fim de compreender por que e para que algumas fotografias foram feitas. Uma foto 
é sempre produzida com determinada intenção, existem objetivos e há arbitrariedade na captação de imagens (BITTENCOURT, 2004, p. 367).

A caracterização das imagens de guerra rendeu a atenção de todos. Em todas as turmas havia uma imagem referente ao holocausto judeu durante a Segunda Guerra Mundial e sua classificação como guerra foi curiosa: uma vez que os alunos não haviam estudado o tema, nem todos sabiam nomeá-lo, embora alguns conseguissem tecer alguma forma de referência ao tema. Alguns alunos indicaram a imagem como uma epidemia e não uma guerra, afinal não havia armas de fogo presentes. Interferi com algumas questões acerca do estado de conservação dos corpos, de modo que para garantir a hipótese de epidemia precisavam prová-la com elementos da própria cena.

Como objeto de estudo nas aulas de História,

As fotos, transformadas em recursos didáticos favorecem a introdução dos alunos no método de análise de "documentos históricos" e, em se tratando da fase inicial da alfabetização, contribuem para que identifiquem ano, nome de lugares e de pessoas ou grupos sociais, além de favorecerem a compreensão do antes e depois e a interiorização do conceito de geração (BITTENCOURT, 2004, p. 369).

Também comentei sobre os informativos de guerra em formato de cinejornais, desenvolvidos por exércitos durante a Guerra, bem como a veiculação de imagens representando diferentes verdades sobre os resultados do conflito. A sustentação de uma suposta veracidade ou legitimidade dessas versões seria possível apenas a partir de uma seleção particular de um conjunto de documentos que sustentasse a argumentação.

Seguindo o cronograma de trabalho do projeto, ainda no primeiro bimestre, após a adesão dos alunos, estes deveriam entregar uma pesquisa de imagens do presidente Getúlio Vargas realizada na Internet, podendo ainda, como sugestão, pesquisar discursos proferidos por ele. Note-se que segundo o programa da escola, os conteúdos a serem desenvolvidos nesse bimestre são Segundo Reinado, República da Espada e República Oligárquica, de modo que estes não puderam subsidiar a pesquisa realizada pelos alunos.

No segundo bimestre, a proposta para os alunos foi a de utilizarem o material pesquisado como base para a elaboração de um roteiro inicial para o filme que iriam produzir. Deveriam ser selecionados alguns recortes dentro do período de governo do presidente Getúlio Vargas. Alguns grupos exploraram os temas que estavam sendo estudados em aula, outros chegaram à carta-testamento do presidente.

Esse roteiro inicial deveria ser discutido com a professora e modificado até tornarse um roteiro possível - geralmente a concepção inicial sofre grandes alterações tanto de 
conteúdo quanto de forma, para que possa ser viável a sua realização. O roteiro final deveria conter indicações das imagens a serem sequenciadas, combinadas à narrativa do filme.

Entre o roteiro inicial e o chamado roteiro possível há uma grande simplificação da forma de apresentação escrita, porém, em geral o conteúdo é ampliado em composições de imagens e significados aludidos ou ainda explicitados por meio da operação de símbolos. $\mathrm{O}$ texto final tem como intenção viabilizar a ação dos alunos para construir cenário, personagens e enquadramentos. Nesse segundo bimestre nasceram as ideias para a confecção dos elementos do cenário e personagens. O roteiro, portanto, é um texto em construção, ou seja, que não possui um formato determinado. Tomamos como objetivo apenas viabilizar a sua realização, e não nos ativemos a um rigor de forma.

Há aqui a aproximação com o específico da linguagem cinematográfica: o filme e o roteiro são divididos em partes, com o objetivo de articular o todo do discurso narrativo. $\mathrm{O}$ exercício permite ver a imagem, torná-la operacional na modalidade descritiva. Os objetivos dos alunos ao criarem o roteiro de seus filmes também seguiam esses eixos constitutivos. Tal como no oficio de roteirista, a escrita deve ser capaz de registrar a cena no papel exatamente da forma como aparecerá na tela, transmitindo o conteúdo exato de cada plano, assim como de sua posição na sequência. Esse processo dialoga com a opção que o diretor fará na montagem da cena, e de sua totalidade.

Na característica estética dessa produção:

$\mathrm{O}$ roteiro de filmagem completo é dividido em sequências divididas em cenas e, finalmente, as cenas mesmas são construídas a partir de uma série de planos, filmado de diversos ângulos. Um roteiro verdadeiro, pronto para ser filmado, deve levar em consideração esta propriedade básica do cinema. (...) A construção de uma cena a partir de planos, de uma sequência a partir de cenas, de uma parte inteira do filme, a partir de sequências e assim por diante, chama-se montagem. A montagem é um dos instrumentos de efeito mais significativos ao alcance do técnico (que escreve o roteiro) e, por extensão, também do roteirista (PUDOVKIN, 2003, p. 57-58).

Foi devido a esse objetivo pragmático do roteirista na cadeia produtiva do filme que denominei a escrita dos alunos como roteiro possível. Em etapas, os alunos transformaram a pesquisa inicial sobre o governo de Getúlio Vargas em um tema, a partir deste criaram um sentido narrativo, registrando, de modo geral o que pretendiam fazer com as informações e, por fim, tornaram essa proposta uma sequência descritiva de imagens, especificando a natureza de seus materiais.

A modalidade discursiva de produção não assume o rigor do ofício do roteirista, mas captura a essência da comunicação e da transformação de uma ideia em diretrizes para a 
captura da imagem. A aproximação dos alunos com esses elementos era de exercício, ou seja, de experimentar essa modalidade discursiva, para organizar e tornar executável uma ideia.

A partir da leitura dos roteiros iniciais, conversei com cada grupo separadamente, para esclarecimentos da montagem propriamente dita do filme, ou seja, como seriam as personagens, onde elas estariam, como seria o cenário, se seria possível cumprir o roteiro. Não há preocupação estética com a forma de apresentação desse roteiro; apenas a necessidade de clareza e explicitação das ideias a serem transformadas em filme.

Notei, nos grupos de 2008, dificuldade por parte na pesquisa e seleção dos recortes a serem apresentados sobre o presidente Getúlio Vargas. Talvez as informações históricas que encontraram em pesquisas realizadas na Internet confirmem a produção historiográfica, capaz de homogeneizar uma dada narrativa sobre o estadista, fato que se reproduziu nos roteiros. Somente quando estudaram o tema em aula uma diversidade maior de recortes sobre o período foi conseguida.

No programa seguido pela escola, os conteúdos pertinentes ao segundo bimestre contemplam quatro unidades: Primeira Guerra Mundial, Revolução Russa, Mundo entre Guerras e Era Vargas10 (1930-45). Deste modo, somente no final do bimestre, próximo à entrega do roteiro final, abordamos o início do governo do presidente Vargas - a elaboração do roteiro inicial não contou, assim, com o subsídio de informações oferecidas pela narrativa da professora ou do material didático utilizado.

No estudo dessa primeira parte do governo do presidente Vargas, não apresentei elementos fílmicos sobre ele. Desejava acionar as representações que os alunos traziam sobre o presidente Vargas por outra via, diferente daquela caracterizada pela memória do cinema. Existia certa ingenuidade de minha parte em não querer induzir os grupos à construção de roteiros parafraseados de obras que viesse a ter assistido em aula.

Essas representações acabaram surgindo a partir do relato, em aula, de alguns alunos, a respeito da memória que seus avós e até mesmo pais possuíam sobre o Estado Novo. Foi possível identificar, nesse ponto, a presença de outras referências para a constituição de uma memória histórica que escapam às aulas, assim como ao professor e ao material didático, denunciando a pluralidade de encaminhamentos narrativos na constituição de uma memória histórica sobre algum evento estudado.

Por ocasião da comemoração do Primeiro de Maio, realizamos a análise de um discurso do presidente Getúlio Vargas, tendo sido acessados o texto escrito e um trecho do

10 Os títulos das unidades são citados de modo idêntico àquele apresentado na apostila usada pelos alunos, sendo necessário, em alguns casos, explicitar o conteúdo ou o período trabalhado em cada uma delas. 
áudio a partir do site www.memoriasdoradio.com.br. A combinação do som sem a imagem do presidente gerou uma outra percepção; abriu-se a possibilidade para que as representações sobre a política nacional tomassem forma, exatamente no momento em que os alunos estavam realizando pesquisas e construindo um roteiro.

No contexto do governo Vargas, estudamos também a participação brasileira na Segunda Guerra Mundial e, ao se darem conta de que o tema seria trabalhado11, os alunos trouxeram para a sala de aula as representações que possuíam do combate, em particular da figura de Adolf Hitler. As imagens que reproduziram em seus discursos variaram entre louco, traumatizado de infância e gay. Com o objetivo de explorar essas representações, procurei demonstrar o modo pelo qual as imagens canônicas são construídas, ou seja, como o cinema é capaz de projetar e sustentar com imagens uma personagem histórica para além dos livros. Nesse caso, a opção foi pela exibição de $O$ Grande Ditador.

Assistimos ao filme logo que estudadas as informações elementares sobre o conflito, ou seja, não havíamos chegado às considerações acerca das bombas atômicas sobre o Japão, de modo que Hitler ainda era o centro das discussões. Há diversas imagens de Hitler e do Terceiro Reich na apostila.

Tenho como costume avisar aos alunos o que faremos nos trabalhos da próxima semana, sempre de modo breve, como um procedimento corriqueiro na escola. A iniciativa se propõe a trazer alguma tranquilidade a eles, diante do elevado número de temas que devemos estudar para as provas. Assim, também avisei que assistiríamos a um filme. Houve curiosidade acerca do título. Comentei apenas que não era um título comum em locadoras embora seja possível que essa informação não esteja correta, pois o filme pode constar da sessão de clássicos.

Diante do tema Mundo entre Guerras ${ }^{\mathbf{1 2}}$, houve a acusação, inclusive recorrente em outros anos: "É, mas Hitler é gay! - Ele é "viado"”! (CC)

Pode até mesmo não fazer sentido inicialmente o desprestígio sexual associado ao líder alemão. Contudo, isso também é uma representação que os alunos trazem de fora dos livros didáticos - onde a encontram? Essa associação não é feita a Mussolini. De toda forma, era um dos objetivos usar esse incidente para analisar imagens do filme. Ao iniciar o filme $O$ Grande Ditador os alunos reconheceram Charles Chaplin.

11 Devido ao fato de usarem e receberem o material apostilado por bimestre, os alunos, em geral, ficam sabendo os temas que irão estudar apenas no início de cada bimestre, perdendo muitas vezes a noção da totalidade do recorte cronológico e temático que estudam na série.

12 Mantive o nome original da unidade estudada. No tema entram as informações referentes à Crise de 1929 nos Estados Unidos e ao Totalitarismo na Europa. 
A partir desse bimestre estabeleceu-se um canal de comunicação mais flexível dos alunos comigo, em que ao anunciar a semana em que ocorreria a exibição de um filme, as aulas passavam a ter o cinema como assunto. Nos minutos finais da aula ou até mesmo após o sinal para o intervalo, um grupo de alunos permanecia na sala para comentar sobre títulos a que haviam assistido e que achavam pertinentes ao tema.

Tal como fizera no bimestre anterior, no dia da exibição, apresentei o título e, enquanto organizava o equipamento, li a ficha técnica, permitindo até mesmo a circulação da embalagem para possíveis conferências. Nessa ocasião, nenhum aluno comentou já ter assistido ao filme.

Ao iniciar o filme, os alunos se queixaram sobre a velocidade com que as legendas eram apresentadas. Houve aqueles que desistiram de acompanhar e também aqueles que redobraram a atenção, evitando conversas paralelas. Houve ainda quem ficasse perguntando o que tinha acontecido.

Durante o filme destaquei junto aos alunos:

- o período histórico em que foi produzido;

- algumas consequências dessa produção para o próprio Chaplin;

- o paralelo estabelecido entre a ficção e a realidade nas personagens de Hinkel e Hitler;

- os créditos iniciais, em que se declara o caráter ficcional do filme;

- as cenas de delírio e insanidade;

- o destaque da cena em que Hinkel brinca com a representação do mundo;

- o recurso potente do humor ficcional gerado pelo diretor;

- a destruição de imagens e símbolos convencionais pela ironia. Em particular nas cenas em que os cientistas apresentam novas tecnologias bélicas e constatam seu fracasso; também no ódio que demonstra em relação ao povo judeu, quando Hinkel discursa a seu povo, chegando até a rosnar.

O objetivo do exercício era explicitar o modo pelo qual a trama é construída, sendo que um mesmo sujeito pode assumir adjetivos distintos, e para além dessa constatação, questionar o motivo pelo qual determinadas qualidades ou defeitos são selecionados pelos diretores. A ficha técnica foi apresentada oralmente no início de cada sessão, enquanto os letreiros iniciais se desenvolviam. Operar com essa personificação da História tal como ocorre a respeito de Hitler, pretendia dialogar com a representação criada sobre o presidente Vargas no Brasil e ainda que essa elaboração não tenha sido explicitada pelos alunos, em suas produções, a memória acaba aproximando ambos os lideres. 
O roteiro de análise do filme que os alunos receberam em 2008 apresentou alguma variação em relação àquele de 2007, no entanto a atividade também foi realizada em aula imediatamente posterior à sessão, em grupos.

A figura 3 apresenta a reprodução do roteiro de análise do filme. Para os comentários acerca das questões nele contidas, contamos com um tempo breve de cerca de 15 minutos, de modo que nenhuma delas foi esgotada, deixando em aberto algumas discussões. Encaminhei determinados elementos básicos de cada uma. Essas discussões contavam sempre com pequenas anotações na lousa, com correspondência ao número do exercício disposto no roteiro. Além de ser exigência das escolas, organiza o trabalho discente e suas anotações no caderno - aqueles que não realizaram a tarefa poderiam, dessa forma, ter alguma noção do que havia sido trabalhado.

\section{$\underline{\text { Roteiro usado para análise do filme O Grande Ditador:13 }}$}

1. Apresente as características totalitárias presentes no discurso fílmico.

2. Caracterize a personagem de Hinkel.

3. Analise as razões que levaram o diretor a optar por um discurso metafórico ao tratar do nazismo.

4. Explique qual você acredita ter sido o efeito imediato provocado pelo filme ao ser veiculado na América e na Europa. Para desenvolver sua explicação observe atentamente a data de produção do filme.

5. Analise a permanência de determinadas representações veiculadas (associadas) à personagem de Hinkel, na imagem sobre o líder nazista.

6. Mesmo tendo sido produzido em 1940, o filme traz alguns elementos que parecem atuais. Escolha uma cena do filme e analise-a sob o ponto de vista da universalidade do discurso.

7. Analise qual foi o recurso usado pelo diretor para dar ao filme um caráter de universalidade.

Figura 3 - Roteiro de análise do filme $O$ Grande Ditador.

Os alunos, de modo geral, ficaram surpresos com o filme de Chaplin. Muitos já tinham ouvido falar dele, mas ninguém o havia assistido anteriormente. A cena em que o

\footnotetext{
13 A proposta de roteiro a ser trabalhada com os alunos deve ser entregue previamente à Coordenadora Pedagógica das Escolas $A$ e $B$, em formato de Plano de Aula. Desse modo, as questões devem seguir um determinado formato de apresentação: iniciar com uma habilidade e explicitar a relação (do filme) com o conteúdo estudado.
} 
ditador brinca com a representação do mundo foi a mais lembrada pelos alunos, seguida do discurso estereotipado para a multidão. Algumas respostas versavam sobre o fato de que: $f a z$ sentido Hitler ser um herói para determinados grupos sociais, dependendo de onde se vê! Ele pode ser louco ou herói, depende o interesse de quem vê! - A possibilidade da alteridade foi celebrada com a lembrança dos agentes da História, bem como com o olhar daqueles que a registram. Foi possível também a manifestação de juízos de valores condenando a ação do líder alemão.

O reconhecimento e o prestígio do título também se tornaram explícitos nas constatações que faziam: "Esse filme passa sempre naquele Telecine Cult ${ }^{\mathbf{1 4}}$, mas eu nunca assisti!" (informação verbal)

A seu modo, esse exercício buscava apresentar a possibilidade de outras representações para um mesmo sujeito histórico, além da que já traziam do universo extraescolar, ou da narrativa da professora, ou da presente no material didático. Extrapolado para a figura do presidente Vargas, já em nossos comentários sobre os filmes dos alunos, justificou o fato de os roteiros que eles estavam elaborando serem significativamente distintos entre si.

Permaneci com o tema da Segunda Guerra como mote para discussão, para que cronologicamente houvesse a retomada das realizações do governo de Getúlio Vargas entre 1930 e 1945. Como era o momento da elaboração dos roteiros, desejava manter o assunto próximo das aulas. Frente à pressão do cronograma de conteúdos sobre as aulas, não é comum retornar a um tema já estudado.

Consta para aqueles que aderiram ao projeto a indicação de atribuição de notas na avaliação de desempenho. Trata-se de $10 \%$ do total de pontos que podem conseguir, em cada um dos bimestres, de acordo com o cumprimento de tarefas. Restam ainda a perda desses pontos para aqueles que desistirem em qualquer uma das etapas. Em 2008, houve desistência de um grupo, de um total de sete nas escolas $A$ e $B$.

Com a entrega dos roteiros finais, iniciaram-se os preparativos dos cenários e personagens, para o terceiro bimestre.

Contamos com 20 dias de férias em julho, sendo que em 2007 havíamos contado apenas com 15 dias. Assim, as atividades foram organizadas, contudo não havia obrigatoriedade de produção nesse período. Um grupo em particular resolveu trabalhar nesses dias. Esse grupo não cumpriu a proibição de encontros domiciliares para a realização da

14 Telecine Cult é um canal de TV por assinatura cujo perfil é a veiculação de filmes clássicos; a seleção dos títulos é dada pela própria história do cinema, através de obras e diretores consagrados. 
atividade, e inclusive anexou ao filme um making of, mostrando a reunião na casa de um deles, sob a supervisão de um pai.

A adesão desse grupo foi distinta, pois entregaram o filme com grande antecedência - no terceiro bimestre já estavam com a animação pronta e inclusive anexada ao portal YouTube!, na conta de um dos alunos. Nesse caso, em particular, destacou-se o capricho na apresentação até mesmo na embalagem, contando com uma cópia do jornal Última Hora, com a primeira página dedicada ao suicídio de Getúlio Vargas. No início do trabalho, esse conjunto de alunos contava com a participação de uma única menina, mas por discordâncias sobre o tema escolhido - O Brasil na Segunda Guerra Mundial e o suicídio do presidente - ela rompeu a colaboração e fez seu próprio filme. Ela também entregou no terceiro bimestre o filme, mas depois do grupo, que contava agora apenas com meninos. Também caprichou na estética da embalagem, embora o formato e os temas selecionados tenham sido distintos, como se poderá verificar em análise posterior.

Em conversas que tive com os alunos da escola $B$, em 2008, acerca de atividades para as férias de julho, sugeri o festival de animação gráfica Anima Mundi, que ocorreu entre os dias 23 e 27 de julho, em São Paulo. Expliquei o modo de funcionamento do festival, bem como seu endereço e a gratuidade na participação. Destaquei as características do evento, da programação e a organização de oficinas de animação. Não pude levá-los com a autorização da escola, uma vez que seria durante o período de férias escolares. Também não é possível realizar uma saída de campo sem que as cinco escolas participem, e não acreditava que houvesse interesse das demais unidades, já que elas nem mesmo conheciam o projeto.

Após as férias, três alunos da escola $B$ contaram que foram ao festival. Quanto à participação, questionei sobre as oficinas que haviam feito e estes declararam:

- Sei lá, Dani, tinha que fazer uma inscrição antes e a gente não fez. Mas foi bom mesmo assim!

- Deu pra assistir uns filmes de graça!

- Achei legal, sei lá! Tinha um povo meio estranho, mas eu gostei.

- Foi um esquisito lá (referindo-se a um dos filmes que assistiram, mas não sabiam o nome).

- Era mesmo um desenho pra adulto. Não era só coisa de criança. (CC)

Também houve atenção do grupo de alunos que estavam próximos e ouviram os depoimentos, enquanto davam as saudações de volta às aulas. Declararam:

- É, vocês são bem folgados mesmo, nem chamaram. Depois eu saio, não chamo, vocês reclamam.

- Meu, nada a ver isso aí! A professora falou pra todo mundo e a gente decidiu ir. Para meu, nada a ver! (CC) 
Em geral, os alunos da escola $B$ em relação aos da escola $A$ possuem maior autonomia para se deslocarem pela cidade, e nessa série em particular. Por ocasião dessa conversa, os alunos envolvidos no projeto dos filmes cobraram informações referentes ao projeto. Essa mesma reação de cobrança foi verificada na escola $A$. Deste modo, combinamos um calendário contendo as atividades a serem desenvolvidas e as semanas de entrega, ou seja, podiam entregar uma atividade em qualquer uma das três aulas que tínhamos na semana.

No terceiro bimestre, após o retorno das férias, os alunos retomaram o projeto, construindo o cenário para o roteiro proposto, as personagens que apareceriam no filme, e também fazendo as fotos, tendo sido estabelecida a quantidade média de 250 a 300, para o filme completo. Esse momento foi literalmente de fabricação de uma ideia.

$\mathrm{Na}$ proposta inicial, cada aluno ou dupla ficou responsável por uma etapa, dividindo tarefas, ou seja, aqueles que prepararam o roteiro não fabricaram o cenário e não iriam bater as fotos. Os ditos escritores passaram, devido à necessidade de encaminhamento dos trabalhos, a ser coordenadores, com a tarefa de garantir a execução do projeto que tiveram.

As construções ocorreram fora do espaço da escola, em casa. Dessa forma, só tive acesso ao material pronto. O que fazia era questionar os grupos acerca de problemas, sendo que todas as respostas, em geral, eram negativas. Decerto essa foi a etapa mais tranquila.

Os conteúdos a serem trabalhados no terceiro bimestre eram a Segunda Guerra Mundial, O Mundo Pós-Segunda Guerra e A República Populista (em que seria trabalhada outra etapa do governo de Getúlio Vargas: de 1951 até sua morte).

Ainda que a interrupção das aulas tenha sido de apenas 15 dias, decidi fazer outra atividade de sensibilização, também porque no bimestre anterior o tempo foi escasso. Esse bimestre em particular seria um período de trabalho intenso em que o Projeto deveria ser preparado, já assumindo o parco número de aulas proporcionadas pelo último bimestre.

Já na primeira aula do terceiro bimestre os alunos receberam a apostila e continuei com a sequência de capítulos a serem trabalhados. Tínhamos a Segunda Guerra e o período posterior a esta como foco. Para tanto, propus novamente uma atividade em que teríamos como ponto inicial um texto e este deveria se tornar alguma forma de composição imagética.

O texto escolhido foi uma poesia - também pretendia explorar essa forma específica de linguagem. A atividade cultural de 2008 tinha como tema alguns escritores, e um deles era o autor da poesia escolhida - Carlos Drummond de Andrade. Aproveitei a oportunidade para uma breve biografia. Tratava-se do poema Congresso Internacional do Medo. Lemos e discutimos o texto. Somou-se a este uma canção do grupo Legião Urbana, 
intitulada Canção do Senhor da Guerra. Quanto a este, especificamente, lemos a poesia, depois ouvimos a música e também tecemos algumas considerações acerca das representações presentes.

Diante desses textos, os alunos deveriam escolher um trecho da canção ou da poesia para transformar em imagem. Deveria estar em folha de papel sulfite. A proposta podia ser realizada em grupo, de modo que cada conjunto de alunos entregaria páginas de composição de imagens capazes de representar toda a poesia ou canção.

O objetivo era avaliar as representações elaboradas sobre o tema da guerra e do medo. Também pretendia a confrontação das imagens produzidas pelos alunos e aquelas que assistiriam dias depois no anime "Gen pés descalços". Comparamos algumas imagens de guerra que trouxeram no bimestre anterior, a composição que fizeram, e comentamos a perda de dramaticidade, e deixei uma questão em aberto: Uma animação pode ter sucesso na hora de falar de guerra, tanto quanto um filme qualquer? - Diante da produção que fizeram concluíram que não. Respondiam-me: não dá pra levar desenho a sério, é apenas diversão!

Trabalhamos também com imagens de conflitos e de objetos de acervos de museus europeus. A dramaticidade das bombas atômicas ganhou um momento especial nas aulas. Interessava-me reproduzir minimamente os horrores do conflito para que essa adesão fosse ponderada.

Necessitava ainda que os alunos conhecessem alguns elementos constitutivos do “mangá". Para tanto, trouxe em transparências a serem projetadas algumas páginas do primeiro volume de Adolf de Osamu Tezuka. Conhecemos algumas características dessa estética, com destaque especial para a representação dos olhos, da boca e da diagramação das páginas.

Na aula seguinte assistimos ao anime Gen pés descalços, de Keiji Nakazawa. Trata-se de um anime - animação no estilo dos mangás, histórias em quadrinhos japonesas de caráter autobiográfico, acerca da vida de um menino japonês no período da Guerra, mais particularmente durante o ataque da bomba atômica de Hiroshima. Desta vez, tanto na escola $A$ quanto na $B$ a sessão foi no laboratório de multimídia, em formato grande.

Na programação, esse era um dos pontos centrais da sensibilização do olhar, posto que era um tema de grande interesse da turma, uma representação carregada de alegoria, e um discurso produzido por quem sofreu o ataque, elevando o seu tom de tragédia.

O ponto inicial foi a apresentação da ficha técnica do filme enquanto organizava o equipamento. Em geral, o uso dos equipamentos do laboratório é complexo e demorado. Há 
sempre uma senha de acesso que ninguém sabe, até que um funcionário específico apareça para ajudar.

Comentei ainda com os alunos a importância de ouvir o outro lado da história, posto que eles mesmos haviam trazido vários títulos de filmes referentes à Segunda Guerra Mundial, todas produções norte-americanas. A proposta de mostrar um novo conjunto de argumentos para sustentar uma versão da história pretendia quebrar a noção de unicidade da versão da apostila. Dessa vez, assistiríamos à versão de um sobrevivente japonês da Segunda Guerra.

A primeira reação dos alunos foi o estranhamento em relação à linguagem - os alunos divertiram-se inicialmente com os diálogos falados e até gritados na língua japonesa. Em todas as turmas das escolas $A$ e $B$, os alunos solicitaram que a sessão fosse apresentada com áudio em português, sem legendas, porém não havia esta opção.

Durante a apresentação destaquei, junto aos alunos:

- A variação de expressões faciais dos personagens em determinadas situações;

- A importância das cores para compor uma mensagem;

- A interferência de elementos naturais, ou seja, a variação entre chuva, sol, céu nublado e o desfecho de um episódio dramático com um arco-íris. O destaque foi a variação da iluminação nas cenas;

- O cuidado em apresentar as personagens norte-americanas em técnica de desenho distinta da utilizada na linguagem do mangá, e o uso do inglês na fala deles;

- A explicação inicial, destacando o Projeto Manhattan, bem como o nome do cientista que dirigiu a equipe envolvida no desenvolvimento da bomba atômica.

Conforme a trama se desenvolvia, nasceu grande expectativa por ocasião da explosão da bomba atômica. Diversos alunos manifestaram oralmente sua angústia e expectativa. Esta também se referia ao tempo da aula, que ia chegando ao seu final verbalizaram o temor de não assistirem a essa parte na mesma aula.

Nas tomadas que antecediam ao estouro da bomba, auge da trama, uma aluna da escola $B$ gritou na aula: “Olha lá uma coisa vermelha!” (CC)

Ela fez referência à cena em que uma garotinha passeia tranquilamente pela rua com sua mãe, segurando uma bexiga vermelha. Na sequência é possível acompanhar sua desintegração, diante da explosão. De fato, a cena em que há o balão vermelho abre a narrativa sobre os efeitos da explosão nuclear. 
No filme, a explosão conta com um momento de silêncio, combinado com um fundo branco, delineado apenas por um contorno em preto. Em seguida, o som de choro, gritos e o incêndio na cidade de Hiroshima. Gen, gritando, tem seu volume elevado automaticamente. A reação foi imediata - uma singular combinação de cenas de destruição e o incômodo sonoro.

Foi no auge dessa narrativa que o apelo sinestésico trouxe reação nos alunos: alguns viraram a cabeça para não ver as cenas do efeito da explosão, em particular os meninos. A esta mesma altura, algumas meninas estavam chorando, em ambas as unidades. Na escola $A$, um aluno sentiu-se de tal forma incomodado que pediu para sair da sala. Ele estava com o rosto entristecido e os olhos mareados, então autorizei sua saída, e ele logo retornou.

Também na escola $A$ o áudio após a explosão incomodou um aluno a tal ponto que comentou: "Nossa, professora, será que não dá pra abaixar isso?” (CC)

Em resposta, uma aluna, que já estava como os olhos mareados, respondeu: "Você acha mesmo que na guerra de verdade dava pra gritar baixo? Como você é burro!" (CC)

A conversa parou e a atenção ao filme voltou. Na primeira turma em que ocorreu a sessão não percebemos o som do sinal que indica o término da aula. Alguns colegas apareceram na porta e interrompemos o filme. Em todas as turmas os alunos saíram resignados e em silêncio. A conversa foi retomada apenas quando encontraram os amigos no corredor.

A veiculação de um filme exige o esforço em demostrar que a sua estrutura entendida como a configuração objetiva da imagem e som organizados de um certo modo - tem afinidades diretas com estruturas próprias ao campo da subjetividade. Reproduzindo, atualizando determinados processos e operações mentais, o cinema se torna experiência inteligível e, ao mesmo tempo, vai a o encontro de uma demanda afetiva que o espectador traz consigo. Como disse Munsterberg, já em 1916, "o cinema obedece às leis da mente, não as do mundo exterior" (XAVIER, 2003, p. 11)

Na aula seguinte à apresentação ocorreu grande interesse pela biografia do autor, o fato de este ter sobrevivido ao ataque da bomba, queriam detalhes de sua saúde, de sua morte, entre outras coisas. De alguma forma houve repercussão na casa de uma aluna da escola $A$, que declarou: "Eu contei pra minha mãe sobre o anime que assistimos na outra aula, e ela te mandou um filme. Uma cópia, na verdade. Depois a senhora diz o que achou." (CC)

O filme que recebi tratava-se de uma espécie de documentário japonês, veiculado em um canal da TV a cabo, sobre as cidades de Hiroshima e Nagasaki, mostrando os efeitos destrutivos do lançamento das bombas atômicas nas cidades. A mãe é filha de japoneses, 
nascida no Brasil. Desde o início, a proposta não era passar o filme inteiro, mas alguns capítulos, de modo que ainda restou parte da trama para assistirem. Solicitaram cópia do filme para assistirem em casa. Tal como fiz no ano de 2007, ofereci a cópia aos interessados. Na escola $B$, uma aluna encontrou um site sobre filmes da Segunda Guerra Mundial e avisou a sala sobre o endereço para fazer download, o qual registramos na lousa.

Outros alunos declararam:

- Nunca pensei que um desenho pudesse me causar tanto horror!

- O desenho era horrível! - Credo!

- Quero assistir de novo!

- Onde eu encontro aquele filme?

- "Da hora" aquele filme! (CC)

Enquanto nos organizávamos para as reflexões indicadas no roteiro, conversamos sobre o efeito que uma animação pode ter. Eles chegaram a comentar a surpresa que tiveram frente a um desenho animado.

O roteiro utilizado para avaliar alguns elementos do anime está reproduzido na figura 4.

Tal como ocorreu em outras ocasiões, a participação oral dos alunos foi mais intensa, em relação às anotações que fizeram para as respostas. Enquanto caminhei entre os grupos para acompanhar o desenvolvimento da atividade, esclareci dúvidas e conversei sobre as impressões que haviam tido na sessão.

Dispus na lousa quatro categorias para que os alunos as visualizassem em paralelo. Foram elas: enredo, construção da imagem, música e sensações. Penso que se tivesse dado aos alunos esse roteiro básico talvez as percepções fossem mais significativas.

Foram criadas quatro categorias: enredo, construção da imagem, trilha sonora, construção da imagem. Na primeira categoria - enredo - pretendia explorar o modo pelo qual a trama, ao menos a parte a que assistiram - foi construída; o papel de histórias menores, que compunham um antes e um depois do ataque da bomba atômica. Há uma dimensão de ruptura com o ataque americano e para tanto se expõe o cotidiano das famílias determinada especificidade.

$\mathrm{Na}$ categoria construção da imagem a minha participação foi mais intensa, fato que certamente dificultou a lembrança espontânea de cenas da animação. As cenas pertinentes ao ataque aéreo norte-americano foram unanimemente abordadas. Utilizei-as para ilustrar alguns elementos, tais como a imagem canônica da criança segurando um balão vermelho em um fundo branco indiciando uma tragédia, ou ainda o uso de cores brancas e pretas para a explosão, ou ainda a alteração do movimento das formigas como um presságio, e até mesmo a 
alteração do tempo: mais lento e sem som na hora da explosão. Foi a metáfora de um segundo que durou uma eternidade. O filme alterna planos abertos e fechados sobre os efeitos do ataque, compondo um clima de drama nacional e pessoal.

\section{$\underline{\text { Roteiro para análise do anime Gen pés descalços }}$}

1. Seu autor, Keiji Nakazawa, tinha sete anos quando sua cidade foi destruída pela primeira bomba atômica. Sobreviveu à tragédia de Hiroshima para se tornar um dos mais aclamados artistas do Japão. Por qual razão seria pertinente conhecer a explicação desse autor sobre o ataque da bomba atômica à cidade de Hiroshima, na $2^{\mathrm{a}}$ Guerra Mundial?

2. Gen Pés Descalços é a história de um menino crescendo em uma família pacifista durante a Segunda Guerra e enfrentando a devastação física e espiritual causada pelo homem.

Identifique no filme ao menos dois elementos que representam a devastação espiritual e física causada pelo ataque e explosão da bomba.

3. Gen Pés Descalços é o relato de um garoto de sete anos que perdeu o pai e os irmãos quando Hiroshima foi atingida pela bomba atômica, em 6 de agosto de 1945. Gen é o próprio autor Nakazawa, que também ajudou sua mãe no parto, no trágico dia. Ela estava grávida de nove meses. O fato de o filme ser apresentado como uma animação gráfica (animê) traz alguma alteração no impacto que a narração causa no espectador? Justifique sua resposta.

4. O autor do animê é um sobrevivente do ataque da bomba atômica de Hiroshima. Ele usou o recurso da arte - mangá e animê - para transmitir sua mensagem. Você acredita que a mensagem teria a mesma repercussão se fosse um filme tradicional? Justifique sua resposta.

5. Faça uma avaliação do filme (O que acharam? As imagens foram boas?).

6. O fato de o filme ser falado em japonês - a única opção de áudio - provocou algum efeito na mensagem do filme? Comente.

7. Comente o silêncio no momento da explosão da bomba.

8. De qual modo os norte-americanos (inimigos) foram representados? Comente a escolha por este recurso (por que eram diferentes dos demais personagens?).

9. Qual a vantagem ou desvantagem de usar animação gráfica ou anime para tratar de temas históricos?

Figura 4 - Roteiro de análise do filme Gen Pés Descalços.

Um dos alunos chamou a atenção para o fato de os pilotos norte-americanos que lançaram a bomba não serem apresentados em forma de mangá, como se estivessem fora da 
história. Em cada uma das turmas a discussão se encaminhou para uma dinâmica diferente. $\mathrm{O}$ ataque foi explorado pelos alunos. Foi nítido o impacto do filme nas turmas envolvidas no projeto, uma vez que nesses casos minha participação foi menor, pois eles próprios encaminharam os debates.

Na terceira categoria - trilha sonora - a maior parte dos alunos não havia prestado atenção à melodia em si, mas na sensação que ela proporcionara. Soma-se a isso o fato de estas terem sido apresentadas em japonês. Porém, quando a quarta categoria sensações - foi apresentada, a música tornou-se pertinente, e nos comentários feitos pelos alunos, a trilha sonora foi completada. A ausência de som na cena da explosão também foi significativa, e as melodias passaram a ser denominadas tristes, alegres, de suspense ou de esperança. Os alunos discutiram ideias entre si, sendo que algumas considerações ficaram abertas, em particular na categoria das sensações.

Os alunos que estavam envolvidos com a produção de filmes participaram ainda mais dos comentários. Um deles declarou: “A música é tão importante no filme, que até o Oscar dá prêmio pra isso!” (CC)

O fato de não existir a obrigatoriedade da escrita também possibilitou maior liberdade de participação. De alguma forma a escrita limita a apresentação oral dos alunos. A linguagem privilegiada da escola também exige determinados formalismos, aos quais alguns alunos preferem não se ater. A exposição das ideias oralmente institui o debate, em um tempo de argumentação e interatividade muito específico.

A animação Gen, parece-me, pegou os alunos desarmados. É possível que não imaginassem que um desenho animado veiculasse uma representação tão intensa da dramaticidade do ataque norte-americano. Essa impressão foi confirmada pelo fato de os alunos terem me solicitado uma cópia do filme para assistirem em casa, também com a intenção de saber o final da trama. Fiz as cópias e estas circularam entre os alunos interessados mediante a organização de uma lista de reservas, que foi organizada pelos próprios alunos sem que eu tivesse que interferir. Durante os dois últimos bimestres havia sempre algum aluno que comentava comigo suas impressões sobre a obra, tanto da parte a que já haviam assistido como da continuação, que viram apenas em casa. Também narravam as impressões de seus familiares. O filme foi devolvido no final do ano.

O processo de desenvolvimento do projeto foi intensificado nesse terceiro bimestre. Além da atividade de sensibilização houve a confecção das personagens e do cenário para a captura das fotos. Devido ao fato de apenas dois alunos por grupo estarem envolvidos com o cenário e as personagens, o trabalho foi rápido. Eles, em particular, tiveram 
as tarefas de casa reduzidas para não sobrecarregá-los nas duas semanas que teriam para se dedicarem a essa fabricação.

Mesmo com tarefas de casa reduzidas praticamente pela metade - eu avisava pessoalmente aqueles alunos que estavam encarregados da confecção e selecionava metade dos exercícios propostos aos demais, sem provocar alarido - não houve diminuição de rendimento dos mesmos em provas. A Coordenação, devido à dinâmica de trabalho, não acompanhou esse tipo de negociação com os alunos. Cada uma das negociações foi feita diretamente com eles; eu não podia deixá-los sem atividades para casa, mas também necessitava que tivessem mais algum estímulo para a realização do trabalho, em meio a tantos outros. Desse modo, eles cumpriram as atividades do projeto e ao mesmo tempo as tarefas prescritas aos demais alunos.

$\mathrm{Na}$ proposta inicial a atividade com os filmes proporcionaria aos alunos envolvidos uma nota de 0 a 4 pontos. No entanto, como havia, em uma mesma sala, alunos que aderiram e alunos que não aderiram ao projeto, todos trabalharam - aqueles envolvidos com a animação trabalharam sem atribuição específica de nota. Embora esse fato não tenha sido explicitado, os alunos percebiam, uma vez que as tarefas excediam a pontuação dada às provas - a cada bimestre anoto em lousa as atividades que irão desenvolver e as notas que serão atribuídas a cada uma delas.

Na data marcada, cada grupo apresentou seu cenário e personagens. Um aluno questionou: "O que os alunos estavam aprontando nas aulas de História com aqueles bonequinhos? Você está contando história para boi dormir!” (CC)

Nessa etapa alguns alunos, de turmas que não participaram das atividades de produção, propuseram participar do projeto; contudo, não foram aceitos.

Ainda no terceiro bimestre, fora do ambiente escolar, os alunos produziram as fotos e as entregaram, em CD, para que eu avaliasse a produção. Não foi fácil apreender a mensagem da animação apenas com as fotos, os roteiros ficaram simplificados e até certo ponto codificados para aqueles que se encarregariam do sequenciamento das imagens.

Certos grupos tiveram problemas técnicos com a iluminação do flash, outros com o deslocamento da câmera, ou ainda com a resolução dada às fotos e a incompatibilidade na gravação. Alguns grupos dividiram entre dois alunos as fotos, cada qual com uma parte do filme, e a resolução das imagens variou. Nesse momento os desafios ficaram por conta da utilização da tecnologia e do domínio pessoal que cada aluno possuía com o computador. O resultado foi uma variável rica, em que alguns grupos entregaram o filme pronto, enquanto outros ainda precisavam de ajuda. Alguns alunos envolvidos no projeto em 2008 recorreram a 
algumas informações técnicas daqueles que já o haviam desenvolvido no ano anterior, de modo que se estabeleceu uma espécie de solidariedade entre os alunos, em particular na escola $B$.

Nessa fase do desenvolvimento do projeto, não pude oferecer aos alunos grande esclarecimento. É também verdade que não surgiram muitas dúvidas, posto que já dominavam um conjunto considerável de informações sobre o programa. No entanto, as fotos enunciaram limites de sensibilidade para organizar os movimentos. As animações foram entregues já prontas, sendo que dois grupos decidiram, já nessa última etapa, não entregar, tendo alegado apenas que não precisavam de nota.

Nesse mesmo período, preparava a apresentação de alguns resultados do Projeto na Semana de Educação da Faculdade de Educação da USP e, portanto, necessitava de alguns filmes com antecedência - pretendia apresentar ao menos um filme no seminário, com o intuito de enriquecer o debate referente ao projeto.

O convite para a entrega antecipada do filme foi feito aberto a todos os grupos e expliquei o uso que faria deles. Ainda que de modo tangencial, era do conhecimento dos alunos que o projeto integrava parte de um trabalho de Mestrado na Universidade de São Paulo. Ainda assim não me questionaram sobre o teor da pesquisa, ou ainda dos resultados que estávamos alcançando.

Os alunos ficaram satisfeitos com a exibição de seus trabalhos na Universidade. De alguma forma a atividade ganhou um sentido mais amplo, trazendo-lhes satisfação, um reconhecimento de suas capacidades para gerar uma forma de discurso capaz de ser comunicada para além dos horizontes das instituições onde o projeto se desenvolveu. Até mesmo o diálogo entre as escolas $A$ e $B$ - do mesmo sistema de ensino - foi inédito.

Em geral, o quarto bimestre é marcado por um esgotamento das atividades. Nesse período, as imagens deveriam estar sequenciadas, com trilha sonora, abertura e créditos, enfim o filme pronto e gravado em mídia.

Em 2008, a primeira prova foi aplicada após quatro semanas do início do bimestre. E o cronograma geral indicava duas unidades a serem trabalhadas: $O$ Brasil sob o Regime Militar e A Nova República - até a eleição para o segundo mandato de Fernando Henrique Cardoso. Houve algumas semanas até a última prova - a chamada prova global que, aliás, foi no último dia de aula. Porém, ambas as unidades deveriam ser trabalhadas já para a primeira prova.

Os estudos que tivemos sobre a Ditadura Militar no Brasil foram intensos. Comuniquei aos alunos algumas das narrativas sobre as ações de militares durante esse 
período que ouvi enquanto lecionava no Colégio da Polícia Militar. As descrições levaram algumas alunas ao choro e ao mal-estar declarado, em ambas as escolas. Os garotos que no início se animaram com as narrativas logo se resignaram.

Também estudamos duas versões acerca dos efeitos que a tortura trouxe aos presos e aos policiais, lendo dois textos: um trecho do livro Brasil Nunca Mais e um do livro Brasil Sempre. O primeiro como uma memória dos presos políticos e o segundo como a justificativa do militares. Encontramos em cada um deles elementos que sustentavam o discurso e o sucesso dessas estratégias. O resultado da argumentação entre a queixa da brutalidade policial e a justificativa de obediência à hierarquia dos militares ofereceu aos alunos a possibilidade do julgamento. Uma aluna comentou que ao contar à sua mãe sobre os textos lidos na aula de História, descobriu que ela possuía um exemplar, já amarelado, com uma dedicatória de seu pai.

Nesse sentido, houve apelo por títulos de filmes relacionados ao período militar. Na escola $B$ uma aluna comentou em aula sobre o filme Batismo de Sangue, ao qual havia assistido. Narrou que havia cenas fortes demais, e sua mãe preferiu passar - creio que se trata de uma sequência de cenas em que há tortura e nudez. Nessa ocasião comentei sobre o livro, com o mesmo título do filme, escrito por Frei Betto. Sobre o filme ela declarou: “Credo, eu não conseguia nem olhar pra televisão. Pra quê toda aquela violência? Minha mãe acabou passando as cenas rapidamente. Que filme a senhora vai passar? Não é daquele tipo? Não é esse não, né?" (CC)

O filme escolhido para análise no quarto bimestre foi $O$ ano em que meus pais saíram de férias, devido ao seu tom auto-biográfico, à narrativa conduzida por um garoto, e à violência não explícita, recurso comum utilizado por outras produções que retratam o mesmo período - como por exemplo, Batismo de Sangue.

Na escola $B$, a exibição desse filme foi na semana anterior à realizada na escola $A$. A dinâmica de organização dos horários de provas pode variar de acordo com a escola. No caso da escola $B$, os alunos do Ensino Fundamental do $6^{\underline{0}}$ ao $9^{\underline{0}}$ anos têm as três primeiras aulas, depois há um breve intervalo e iniciam-se então as avaliações, até o final do período. De acordo com a Coordenação, devemos seguir com as aulas normalmente nessa semana de provas.

No entanto, já faz parte da tradição os alunos terem essas aulas para os estudos e preparação que não realizam em casa. Esse é o período de menor adesão dos alunos às atividades propostas. Desse modo, busco estratégias distintas para resolver a questão. Nessa situação, resolvi adiantar a sessão do filme. Nós o assistimos em aula, com a iluminação 
apagada e as cortinas fechadas, diminuindo as possibilidades de atividades de estudo para a prova do dia.

Li a ficha técnica tal como nos bimestres anteriores. Fiz um breve relato do enredo, enquanto preparava os equipamentos. Avisei que assistiríamos a todo o filme, ao contrário daqueles dos bimestres anteriores, em que a sessão contava apenas com uma seleção de cenas. Dessa forma, usaríamos aproximadamente as três aulas previstas para a semana.

Na sessão desse último filme não apenas indicava o que devia ser observado, mas já procedia a uma análise. Destaquei os seguintes elementos:

- O simbolismo do cigarro nas cenas iniciais e a tensão da fuga da família de Mauro personagem principal e narrador.

- A cena de panorama fechando em uma farpa de arame.

- O uso de uma linguagem específica do grupo judeu.

- A caracterização estética da comunidade judaica.

- A personagem Hanna como exemplo da manutenção da tradição judaica.

- Os costumes judeus, como a circuncisão, o Bar Mitzvá e a culinária.

- A coleção de figurinhas dos jogadores da Copa, sem serem autocolantes como as de hoje.

- Pichação, na parede, da frase: Abaixo a Ditadura!

- O ambiente do local das gravações - o bairro do Bom Retiro.

- A importância do rádio na transmissão de notícias.

- A comemoração diante dos jogos da seleção brasileira na Copa e o apelo por uma faceta do nacionalismo.

- O único personagem negro como goleiro e namorado da mocinha.

- O jogo de futebol entre italianos e judeus, e o goleiro negro, salvador do time judeu.

- A frase de Mauro: Agora eu já sei o que quero ser quando crescer: negro e voador!

- O ambiente universitário e a repressão.

- A solidariedade garantindo a manutenção de comunidades da resistência ao Regime Militar e dos judeus.

$\mathrm{Na}$ turma do $9^{\circ} \mathrm{B}$ nenhum aluno havia assistido antes ao filme. Ao bater o sinal para a troca de professores, houve grande insistência para que eu pedisse a aula do outro professor para terminar a sessão. Eles sugeriram:

- Pede pro outro professor deixar o filme passar [tratava-se do professor de Física], ele não está dando mais nada, mesmo. Não vai brigar se você ficar com a aula dele.

- Na sexta vai continuar? (CC) 
É certo que aqueles alunos que não se interessaram pelo filme nem mesmo manifestaram sua opinião. Não pedi ao outro professor, e segui para a outra turma. Nessa, um aluno já havia assistido ao filme, e resolveu anunciar algumas cenas que se seguiriam. Também tentou contar o final, mas foi silenciado pelos protestos da sala. Na sessão, contei com a presença de duas alunas da outra turma. Elas resolveram fugir da aula do outro professor. Conferi e ele havia autorizado as duas alunas a me acompanharem. A recepção não foi exatamente cordial, mas as alunas argumentaram e eles se calaram.

“- Ei, o que é isso? Que vocês estão fazendo aqui?

- Aí, não enche o saco, meu!" (CC)

As alunas esperaram o meu posicionamento na sala e se sentaram próximas. Elas já haviam assistido à primeira parte do filme, mas repetiram a dose, e uma delas aproveitou para conversar:

- Olha que cena boa! (Referia-se a uma cena em que um carro segue pela estrada em uma cena de panorama e fecha o foco em uma farpa de arame).

- Aposto que isso quer dizer alguma coisa. (aluna)

- O que você acha que é? (perguntei)

- Acho que é a violência da Ditadura: mesmo sem ninguém ver, ela está lá! (CC)

Também houve reação de uma aluna que não participa oralmente da aula com regularidade, diante da cena em que se desenrola a comemoração do Bar Mitzvá e da cena das pernas das crianças dançando, colada à das patas de cavalos que avançam:

- Quando alguém está feliz demais, eles [os militares] aparecem para detonar.

- São os militares! Eles tinham que aparecer pra acabar com tudo.

- Nossa como você está ficando esperto! Até pensei que fosse o príncipe encantado. (CC)

A aluna ainda questionou: "E essa bacia, Dani? Também quer dizer alguma coisa... Na cena ela não serve para nada, mas deve servir para alguma coisa.” (CC)

Questionei sobre a representação que ela conseguia perceber, e ela me respondeu: "Não sei! Parece uma coisa velha e quebrada." (CC)

Insisti sobre o significado de velho, e ela completou: "É esse jeito besta deles (os judeus do enredo) viverem, sem ligar pra nada." (CC)

Frente à resistência apresentada diante da escrita, no relatório de análise dos filmes assistidos durante o ano, resolvi adotar outra estratégia. Logo que terminou a última fala do filme, encaminhei a proposta oralmente: cada aluno, assim que se sentisse preparado, deveria levantar, em silêncio - insisti para que ninguém se comunicasse -, pegar um giz no 
aparador e escrever uma única palavra na lousa, capaz de traduzir o que sentiram sobre o filme. Os resultados estão mostrados na tabela 2.

Tabela 2 - Associação livre sobre o filme $O$ ano em que meus pais saíram de férias (escola $B$ ).

\begin{tabular}{|c|c|}
\hline Turma: $8^{\mathrm{a}} \mathrm{A}^{\mathbf{1 5}}$ & Turma: $8^{\mathrm{a}} \mathrm{B}$ \\
\hline Fuga & Chocante \\
\hline Pelé & Solidão \\
\hline Comunismo ( 2 vezes) & Triste \\
\hline Ditadura & Reflexivo \\
\hline Saudade & Atrativo \\
\hline Militares & Incrível \\
\hline Esilados (exilados) & Verdadeiro (2 vezes) \\
\hline Tostão & Conflitante \\
\hline Judeu & Huhu \\
\hline Tortura (2 vezes) & Realidade/Realista \\
\hline Família & Fiel (corinthiano) \\
\hline Copa & Comovente \\
\hline Nacionalismo & Sonho \\
\hline Deus & Campeão \\
\hline Mauro & Emocionante (2 vezes) \\
\hline Brasil & Terrível \\
\hline DEOPS & Profundo \\
\hline \multicolumn{2}{|l|}{ AI-5 } \\
\hline \multicolumn{2}{|l|}{ São Paulo } \\
\hline \multicolumn{2}{|l|}{ Gol } \\
\hline \multicolumn{2}{|c|}{ Ingride (nome de uma aluna parecida } \\
\hline \multicolumn{2}{|l|}{ com a personagem Hanna) } \\
\hline \multicolumn{2}{|l|}{ Bom Retiro } \\
\hline \multicolumn{2}{|l|}{ Jogo de Botão } \\
\hline \multicolumn{2}{|l|}{ Sonho: Negro e Voador } \\
\hline Bar Mitzvá & \\
\hline
\end{tabular}

15 Alguns alunos do $8^{\circ}$ A pediram para escrever mais de uma palavra. Autorizei. 
Combinei que falaria apenas quando eles terminassem os registros. Seguiram a proposta e não conversaram enquanto escreviam. Aqueles que já haviam escrito voltavam para o lugar em silêncio, depois conversavam entre si sobre a palavra que haviam escrito.

$\mathrm{Na}$ aula seguinte, passei na lousa as palavras que eles próprios haviam escrito e as frases Eu já sei o que quero ser: negro e voador! e também Acho que mesmo sem querer eu virei um exilado. E exilado quer dizer: ter um pai tão atrasado, mas tão atrasado que nunca volta pra casa., para tecermos alguns comentários sobre o filme. Uma aluna declarou que "o filme foi triste porque mostrava a violência não apenas aos comunistas, mas também às famílias, e isso era difícil de aguentar." (CC)

Na escola $A$ as avaliações bimestrais já tinham sido realizadas e os alunos queriam saber as notas. Porém nesse quarto bimestre existe uma recomendação da Coordenação Geral para que não se divulguem os resultados, tampouco se apresente o gabarito da última prova, para evitar qualquer possibilidade de os alunos calcularem suas médias bimestrais. Desse modo, propus a sessão, também, para evitar qualquer insistência dos alunos.

A frequência dos alunos foi menor que a de costume, e propus a sessão para as turmas juntas. Assim assistiríamos ao filme inteiro no mesmo dia. Para tanto, usaríamos uma sala do $3^{\circ}$ ano do Ensino Médio, por ser construída para cerca de 80 alunos, contar com arcondicionado e equipamento para projeção em telão já instalado.

Solicitei o acompanhamento dos professores de cada turma. Eles concordaram, porém, dos quatro professores esperados apenas dois apareceram. O número de alunos também foi superior às minhas expectativas - eram 90. Também tive problemas para ligar o equipamento, que possuía uma senha que eu desconhecia. A atividade foi um fracasso e retornamos às salas.

Após o primeiro intervalo, insisti com a atividade, desta vez unindo os alunos de apenas duas turmas: $8^{\text {as }} \mathrm{C}$ e $\mathrm{D}$, sob minha supervisão e de outras duas professoras, separadamente. Também preparei o equipamento previamente. Alterei o local de apresentação, pois os alunos do Ensino Médio deviam retornar à sala. Seguimos para o Laboratório de Multimídia. Nesse formato, não acompanhei o meio da sessão.

Realizei a mesma proposta de associação livre e o resultado consta da tabela 3. Uma aluna rompeu o silêncio enquanto os demais registravam na lousa as palavras: "O filme não fez nenhum efeito em mim. É pra escrever qualquer coisa?" (CC)

Também realizei a sessão na 8” $\mathrm{A}$. E uma aluna declarou: "É sempre bom assistir filme aqui. Esse aí eu já tinha assistido e parece que nem vi. Aqui eu consigo ver outras coisas, não é só a história. Acho bom!” (CC) 
Tabela 3 - Associação livre sobre o filme $O$ ano em que meus pais saíram de férias (escola $A)$

\begin{tabular}{|c|c|}
\hline Turma: $8^{\mathrm{a}} \mathrm{A}$ & Turma: $8^{\mathrm{a}} \mathrm{B}$ \\
\hline Repressão & Perda \\
\hline Censura & Saudade \\
\hline Stálin & Férias \\
\hline Será? & Tortura \\
\hline Morte & Dor \\
\hline Prisão & Tristeza \\
\hline Férias & Copa \\
\hline Medo & Bandeira \\
\hline Esperança & Exilado \\
\hline Comunismo & Liberdade \\
\hline Pode Pah & Realista \\
\hline Família & Injustiça \\
\hline Ditadura & Ditadura (2 vezes) \\
\hline Que representa? & Esperança \\
\hline Exilado & Copa (2 vezes) \\
\hline Prissão (prisão) (2 vezes) & Abusos \\
\hline Morte & Roberto Carlos \\
\hline Força & 1970 \\
\hline Superação & Triste \\
\hline Saudade & Feliz Aniversário! \\
\hline Colaboração & Tortura \\
\hline \multirow[t]{2}{*}{ Solidariedade } & Tristeza \\
\hline & Morte \\
\hline
\end{tabular}

Alguns alunos ficaram aflitos para saber o destino dos pais da personagem Mauro, e questionavam em momentos diferentes da apresentação:

“- Os pais dele morreram? Vão morrer?

- Conta professora: vão matar os pais dele?

- Os pais dele vão voltar?” (CC)

A própria turma censurava a ansiedade dos colegas, afirmando:

"-Calma meu! 
- Meu, cala a boca!" (CC)

Foi curiosa a reação de censura diante da interrupção do silêncio na sessão. Interfiro diversas vezes e eles nunca reclamaram. É certo que me cerco de cuidados para realizar essas interferências. Procuro sentir a sala, observando a atenção e o envolvimento que estão dedicando a ela, pelo grau de silêncio que mantêm, disposição física em relação à televisão, forma com que se colocam para se sentirem mais confortáveis e atenção que dedicam a meus comentários. Permaneço um pouco aflita, tento interferir na medida certa; dessa forma, a indicação dos elementos destacados em cada um dos filmes pode variar conforme o comportamento da turma.

Recebi o empréstimo de um documentário do pai de uma aluna da $8^{\underline{a}}$ A. O título é Nós Resistimos!. A produção trata da resistência ao Regime Militar praticada por grupos de estudantes e professores do interior de São Paulo, os quais resistiram à Ditadura, bem como descreve as punições que receberam na ocasião. Os comentários históricos presentes no filme são narrados pela professora Maria Aparecida Aquino, da Faculdade de Filosofia, Letras e Ciências Humanas da USP. Alunas que presenciaram o empréstimo solicitaram uma ocasião para também assistirem ao filme.

Na última semana de aula, as atividades já seguiam outro ritmo de realização. A última aula seria a prova global. Uma professora de Português teceu alguns comentários acerca de uma atividade que desenvolveu junto aos alunos do $1^{\underline{0}}$ ano do Ensino Médio e que considerava modelo de sucesso. Ela descreveu uma sessão de filme que realizou. $\mathrm{O}$ filme era Sociedade dos Poetas Mortos. Além da atenção que os alunos dedicaram à atividade, realizaram comentários que a surpreenderam. Ela declarou: "Eles não comentaram apenas o enredo, mas sabiam o que significava cada uma das coisas da cena. Sabe aqueles símbolos do cinema, eles conheciam. Imagina! - Nem pensei que eles iam se interessar" (CC). Interesseime pela descrição, uma vez que alguns deles haviam sido meus alunos no ano anterior. Pedi que ela desse um exemplo dos comentários que fizeram.

“- Teve uma cena em que os professores e os alunos entraram num impulso e a primeira atitude do professor foi arrancar uma página do livro, e isso provocou um efeito neles. O André analisou o peso de arrancar a página como uma quebra da tradição e uma atitude de extrema rebeldia. (CC) - A Jéssica - ela é ótima né?! -, ela fez um comentário muito bom. Disse que uma revolução não acontece assim de repente. Começa de dentro. Arrancar a página foi uma atitude. Ela falou que sempre tem alguma coisa antes, durante e depois" (CC).

A professora contou ainda que os alunos explicaram que haviam aprendido muito sobre filmes nas aulas de História do ano passado. 
Devido às vicissitudes da rotina em cada um das escolas, a atividade final, que consistia em apresentar aos alunos todos os filmes produzidos durante o ano -, não foi realizada na escola $A$. A sobrecarga de trabalho solicitado pela Coordenação, no quarto bimestre foi a causa dessa impossibilidade.

Os alunos da escola $B$ assistiram às animações diretamente no portal do YouTube!. Não usei as mídias que me entregaram, posto que os grupos gravaram suas animações em formatos de arquivo diversos e, desse modo, nem sempre é possível exibi-los em qualquer computador, apenas naqueles que contam com os softwares específicos para reprodução desses formatos. $\mathrm{O}$ acesso a esse portal é normalmente bloqueado, mas por ocasião de uma denúncia de um filme de alguns alunos depreciando a escola, estava liberado, e o usamos em aula.

É evidente que ao avisá-los sobre a atividade, a adesão foi unânime. No entanto, havia maior expectativa com relação aos filmes produzidos pelos alunos da própria escola. Estes foram os primeiros veiculados. Os alunos reagiram com admiração diante do trabalho que realizaram; até mesmo os grupos que fizeram making of reagiram, mas desta vez com descontração e risos. A reação curiosa ocorreu quando os filmes produzidos pelos alunos da escola $B$ se iniciaram. Embora haja uma espécie de disputa entre as escolas, ocorreu o reconhecimento pelo trabalho realizado. A evidência se deu com o silêncio e a atenção que dedicaram à sessão.

No início, uma aluna se posicionou a respeito de um filme da escola $A$ : "É, eles fazem esse tipo de coisa sempre! - São todos riquinhos, são tudo filhinho de papai." (CC)

Insisti na questão econômica da produção e no resultado conquistado por um grupo de alunas da escola que usaram o próprio corpo como personagens, para narrar parte da trajetória política do presidente Vargas. Outro aluno acrescentou: "Não tem nada a ver isso aí, meu! Os caras fizeram direitinho, e é isso que a Dani quer mostrar! Não é, não, professora?" (CC)

De alguma forma, a solidariedade ao trabalho de colegas da mesma escola criou um sentido de respeito para a produção. Não se ouviram conversas paralelas, apenas silenciaram diante dos filmes. Também assistimos aos filmes participantes do projeto no ano de 2007. Ocorreu uma espécie de prova, uma comparação. Embora o posicionamento não fosse evidente, tomaram as produções da casa como as mais legais, mas teceram elogios à técnica e ao enredo de alguns filmes da escola $A$.

Em geral, os alunos não conhecem a produção do colega da mesma sala. Tampouco há divulgação de atividades entre turmas e escolas, pelo contrário! Há um clima de 
disputa, de comparação de resultados e desempenho nas avaliações. Para os alunos, contudo, pode ser um momento especial de conhecerem a produção do outro, além de confrontarem estereótipos que constroem ao longo dos anos.

Organizamos uma sessão em cada uma das turmas, de modo a assistirmos toda a produção da sala, e as dos demais colegas. Depois, assistimos novamente, com o comentário dos produtores, explicando algumas imagens criadas e os símbolos que operavam. Por fim, assistimos mais uma vez, para que as turmas pudessem tecer seus comentários acerca dos trabalhos.

A primeira dificuldade que tive foi deixar claro para os grupos que o objetivo era o discurso imagético que produziram e não a parte plástica do filme. Houve determinada frustração nesse sentido, uma vez que os alunos desejavam uma boa imagem, ou seja, bem feita, sem problemas de nitidez e de movimentos bruscos. Esse foi um limite de ordem técnica que não obstruiu o objetivo inicial, mas que desanimou alguns grupos.

Para tentar dar conta de todos os filmes, realizamos, em lousa, uma espécie de categorização dos mesmos. Assim, tentamos perceber que, embora operando com símbolos distintos acerca das décadas de 1930 a 1950 sobre o governo de Getúlio Vargas, existiam elementos de contato entre os grupos, uma vez que a temporalidade era a mesma. Evidenciouse a possibilidade dos recortes na História, no entanto essa diversidade, rica em significação, também proporcionava dificuldades, posto que seria necessária uma sistematização desses diferentes recortes.

Ao fazer um balanço crítico do Projeto, a questão central trazida pelos alunos foi a falta de tempo: "podíamos ter feito melhor!" ou "se você for pedir filme de novo, avisa no primeiro dia de aula!" (CC) 


\title{
Capítulo 2 HISTÓRIA, CURRíCULO E AS AULAS
}

\subsection{Algumas considerações sobre o ensino de História no Brasil}

\begin{abstract}
Articular historicamente o passado não significa conhecê-lo "como ele de fato foi". Significa apropriar-se de uma reminiscência, tal como ela relampeja no momento de um perigo. (...)

Cada manhã recebemos notícias de todo o mundo. E, no entanto, somos pobres em histórias surpreendentes. A razão é que os fatos já nos chegam acompanhados de explicações. Em outras palavras: quase nada do que acontece está a serviço da narrativa, e quase tudo está a serviço da informação (BENJAMIN, 1994).
\end{abstract}

O presente capítulo não se pretende a traçar um histórico detalhado acerca da organização do ensino de História no Brasil e suas alterações curriculares - para essa tarefa convém consultar as obras dos professores Circe Bittencourt e Leandro Karnal ${ }^{\mathbf{1 6}}$, além dos Parâmetros Curriculares Nacionais (PCN) de História e Geografia. Antes, propõe-se a mapear os objetivos gerais que subsidiam a manutenção desse saber ministrado nas escolas, com o objetivo de melhor analisar a proposta desenvolvida na experiência pedagógica.

A história do ensino de História oferece de antemão algumas possibilidades de arranjos pedagógicos, tais como a seleção e a organização de temas, os quais são apresentados nos livros didáticos e reproduzidos em sala de aula, ainda que dialoguem com a família e a mídia, por exemplo.

É pertinente citar aqui, por ocasião da análise de uma experiência pedagógica, os filmes produzidos pelos alunos e o seu processo de produção, mas convém lembrar que eles foram realizados segundo uma determinada orientação acerca do ensino de História, bem como de tema, previsto no currículo. Desse modo, o currículo se expressa como um artefato cultural no formato dos filmes, e nele há uma memória de um modo específico de se aproximar dos temas da História.

A temática do currículo me é cara, na medida em que localiza as questões desta pesquisa em relação a uma sequência de debates travados acerca do conteúdo e da forma que o saber histórico assume na sala de aula. A seleção de temas responde a certa memória, e a

\footnotetext{
16 Refiro-me aos livros Ensino de História: fundamentos e métodos, de Circe Bittencourt, e História na sala de aula: conceitos, práticas e propostas, de Leandro Karnal (org.)
} 
apresentação de um panorama da história do currículo desse saber no Brasil parece-me indispensável, ainda que brevemente.

De acordo com os PCN de História e Geografia, "a constituição da História como disciplina escolar autônoma ocorreu apenas em 1837, com a criação do Colégio Pedro II, o primeiro colégio secundário do País, que apesar de público era pago e destinado às elites". O ensino de História, nesse período, confirmava o caráter da tutoria dedicada aos filhos da elite, em que os temas europeus mereciam mais destaque que os nacionais.

A percepção de um conjunto de informações válidas para explicar os processos nacionais foi inaugurada com o Império. "A História do Brasil foi introduzida no ensino secundário depois de 1855" (BRASIL, 2000, p. 20). Verificou-se, nesse período, o esforço de setores ligados à elite intelectual do país em incluir algumas informações históricas na escola primária: não há a presença da História como uma disciplina, mas sim como tema dos textos que seriam usados para exercitar a leitura e a escrita, que eram os objetivos essenciais desse nível de escolarização.

Também devido à forte influência que a Igreja Católica Apostólica Romana exercia sobre o Estado nesse período, os temas privilegiados de História eram aqueles referentes à chamada História Sagrada e seu suporte na Bíblia. A metodologia empregada seguia os princípios de um modelo específico de catequese, em que havia texto e questões de fixação de suas informações elementares, de modo que as técnicas mnemônicas eram privilegiadas.

A formação de professores não contava com a especialidade do conhecimento histórico, reforçando ainda o ensino da História Sagrada, devido à permanência das aulas de religião católica que os alunos recebiam.

Ainda durante o Império, no final da década de 1870 novas reformas alteraram os temas do ensino de História, devido ao desenvolvimento de debates sobre o ensino laico e questões de ordem política; a História da nação deveria ser ensinada. Para forjar esse currículo foram criados alguns pontos centrais, em torno dos quais seriam amarrados outros temas, ou seja, a Independência e a criação do Estado Nacional era a base. Mesmo com essa rearticulação dos conteúdos, a forma permaneceu a mesma, ou seja, as técnicas apenas mnemônicas prevaleceram. É possível perceber o esforço do Estado em controlar a narrativa sobre o saber Histórico que será veiculado aos alunos, esse suposto controle pretendendo garantir a homogeneidade do discurso.

A organização de uma configuração republicana já no final do século XIX e sua inauguração em 1889 favoreceu o debate a respeito de um ensino que se constituísse em 
agente da transformação do país, tendo como modelo as potências européias. O Estado era o principal condutor dessa discussão e, na História, os alunos deveriam estudar as demais civilizações com esse olhar de desenvolvimento e tendo-os como modelo. Para suprir a fragilidade do regime republicano que se instalava, uma nova articulação da narrativa foi feita, outra seleção de fatos e heróis foi articulada e os saberes históricos foram também um veículo para esse outro arranjo.

A História passou a ocupar no currículo um duplo papel: o civilizatório e o patriótico, formando, ao lado da Geografia e da Língua Pátria, o tripé da nacionalidade, cuja missão na escola elementar seria de modelar um novo tipo de trabalhador: o cidadão patriótico (BRASIL, 2000, p. 22).

O efeito imediato foi o estabelecimento de um calendário escolar de comemorações cívicas. Os símbolos pátrios como hinos e bandeiras eram evocados nessas ocasiões, de modo que o ensino de História também obedecia a interesses circunstanciais ao longo dos meses do ano, para levar a cabo as festividades. O privilégio das comemorações contribuiu ainda para a composição de uma narração que celebrava o passado e não necessariamente refletia sobre ele. Desse modo, se extinguia o conflito social, o qual transforma os efeitos da abolição tardia no país, ou ainda a imigração, em um discurso de democracia racial e étnica.

Com a consolidação da república, outras propostas de organização da escola foram implantadas no Brasil. As escolas anarquistas foram uma delas, nas quais os movimentos sociais eram privilegiados. No entanto, a inserção dessas experiências educativas aqui pretende apenas chamar a atenção para a multiplicidade de variáveis de um projeto de ensino de História, pensado para a nação por diferentes setores da sociedade, ainda que a elite permaneça aquela com a memória mais difundida. Nesse breve panorama sobre a história do ensino de História já é possível perceber que não há uma possibilidade única de organização do currículo ou da forma como esse saber é ministrado; a pluralidade existe ainda que um discurso hegemônico articule o campo.

Uma tentativa de centralização dos temas curriculares pelo Estado brasileiro ocorreu com a criação do Ministério da Educação e Saúde Pública, na década de 1930. Com a reforma educacional liderada por Francisco Campos ficaram estabelecidos padrões para todo o país daquilo que deveria ser ensinado. Em História houve uma confirmação da laicização da educação e a escolha da História Geral como eixo norteador, no qual a História do Brasil deveria ser inserida a reboque. 
Mesmo sob a influência dos princípios pedagógicos escolanovistas - aqui é possível citar as leituras e propostas de Lourenço Filho, que atuou em cargos de direção de projetos educacionais criados no país $\mathbf{1 7}$, da obra de John Dewey, uma vez que o movimento da Escola Nova conta com diferentes autores -, em que o método ativo é privilegiado, os materiais didáticos produzidos pelo Estado ainda trazem a preponderância das técnicas de memorização.

Ainda sob o Estado Novo (1930-45) as especificidades do conhecimento histórico foram substituídas pelo ensino de Estudos Sociais, em que por meio da mescla de saberes da História e da Geografia permitiu-se a veiculação de um conjunto de informações cujo viés ideológico pretendia justificar o modelo de estado já estabelecido.

Houve um tempo em que o ensino da História nas escolas não era mais do que uma forma de educação cívica. Seu principal objetivo era confirmar a nação no estado em que se encontrava no momento, legitimar sua ordem social e política e ao mesmo tempo seus dirigentes. E inculcar nos membros da nação - vistos, então, mais como súditos do que como cidadãos participantes - o orgulho de a ela pertencerem, respeito por ela e dedicação para servi-la. O aparelho didático desse ensino era simples: uma narração de fatos seletos, momentos fortes, etapas decisivas, grandes personagens, acontecimentos simbólicos e, de vez em quando, alguns mitos gratificantes. Cada peça dessa narrativa tinha sua importância e era cuidadosamente selecionada (LAVILLE, 1999, p. 126).

Após a Segunda Guerra Mundial, foram criados órgãos supranacionais com a atribuição de propor diretrizes para a educação mundial. Estes valorizavam a pluralidade social e alertavam para os perigos na ênfase dada ao modo de apresentar a história nacional.

A Unesco passou a interferir na elaboração de livros escolares e nas propostas curriculares, indicando possíveis perigos na ênfase dada às histórias de guerras, no modo de apresentar a história nacional e nas questões raciais, em especial na disseminação de idéias racistas e preconceituosas. A História deveria revestir-se de um conteúdo mais humanístico e pacifista, voltando-se ao estudo dos processos de desenvolvimento econômico das sociedades, bem como dos avanços tecnológicos, científicos e culturais da humanidade (BRASIL, 2000, p. 25).

Estas percepções também chegaram ao Brasil juntamente com o nacionaldesenvolvimentismo das décadas de 1950 e 60 . A presença dos Estados Unidos como parceiro econômico favoreceu certo imperialismo cultural, e a História da América, em especial a estadunidense também passou a ser conteúdo estudado na escola.

17 Lourenço Filho atuou em cargos de direção dos projetos educacionais criados no país a partir da década de 1930. Para maiores informações sobre o pensador conferir MONARCHA, Carlos \& FILHO, Rui Lourenço (org). Por Lourenço Filho: uma biobibliografia. Brasília, DF, Inep/MEC 2001. 
Outra alteração substancial ocorreu com a promulgação da lei 5.692 de 1971, em que o ensino de História e Geografia foram novamente substituídos pelos Estudos Sociais. A especificidade de cada uma dessas ciências cedeu espaço para o civismo, com a apresentação de temas nacionais e internacionais maquiados com contornos nacionalistas capazes de sustentar a ordem política e social estabelecida.

Uniram-se a esse quadro específico sobre o ensino de História outras reformas na área da educação, as quais também repercutiram sobre a organização do currículo, tal como o fim do exame da admissão, cuja consequência foi a ampliação do número de alunos na Educação Básica, havendo, consequentemente, falta de professores para suprir as aulas nessas novas salas. A solução pensada foi então a criação de cursos de licenciatura curta, com habilitação em Estudos Sociais. A partir da organização dessa nova modalidade de graduação os temas do currículo específico em História foram esvaziados.

A manifestação dos historiadores e professores veio de modo organizado com a criação da ANPUH (Associação Nacional dos Professores Universitários de História) e AGB (Associação Geográfica Brasileira), ambas formadas ao longo da década de 1970. Os efeitos foram vistos claramente na década de 1980, início do processo de redemocratização do país, em que foram debatidas reformas curriculares e houve pressão pelo retorno da História e da Geografia como temas específicos.

Nesse âmbito, a transformação foi possível também devido ao significativo aumento da produção em nível de pós-graduação nessas áreas do conhecimento, bem como na área da pedagogia. É exatamente desse imbricamento que nascem os debates acerca da forma e dos conteúdos que serão abordados, particularmente, no ensino de História.

De todo modo, frente a duas propostas, a saber, o trabalho com o conhecimento histórico a partir de temas apresentados aos alunos e a ordenação sequencial e processual que intercala os conteúdos de História Geral e do Brasil, pretende-se articular o desenvolvimento de um pensamento crítico, porém esse exercício passa pelo controle social na própria organização da narrativa histórica que será veiculada. Independentemente de seu formato, é necessário ter com clareza a presença irrestrita de uma memória do ensino de História e que a sala de aula não é o único espaço de narrativa; outras instituições sociais e mídias contribuem nessa tarefa.

Aqui se afirma que os temas do currículo de História obedecem a uma lógica social criada no tempo presente e carregada de intencionalidade, seja ela de caráter democrático ou ditatorial. E que esta é uma parte da narrativa sobre a nação, explicitando aqui 
a existência de uma pluralidade discursiva, permitindo uma configuração multifacetada, e que nem sempre é o discurso escolar aquele que ressoa com maior vigor nos indivíduos.

Convém aqui uma ponderação sobre o suposto caráter formador de identidade nacional atribuído ao ensino de História:

Tudo isso para dizer que é possível que todos esses esforços para controlar os conteúdos do ensino de História, bem como os debates que isso provoca, estejam alicerçados em uma ilusão. Nesse fim de século, é possível que a narrativa histórica não tenha mais tanto poder, que a família, o meio ao qual se pertence, circunstâncias marcantes no ambiente em que se vive, mas sobretudo os meios de comunicação, tenham muito mais influência. O que deveria nos levar a não perder de vista a função social geralmente declarada hoje a respeito do ensino de História: formar indivíduos autônomos e críticos e levá-los a desenvolver as capacidades intelectuais e afetivas adequadas, fazendo com que trabalhem com conteúdos históricos abertos e variados, e não com conteúdos fechados e determinados como ainda são frequentes nas narrativas que provocam disputas. Senão, essas guerras de narrativas desencadeadas em todo o mundo vão acabar gerando somente perdedores, tanto no que diz respeito à identidade nacional quanto em relação à vida democrática (LAVILLE, 1999).

O alerta trazido pelo pesquisador canadense dialoga com a experiência pedagógica analisada nesta pesquisa. Mesmo que a proposta inicial dessa experiência não tenha sido previamente pensada à luz da percepção da guerra de narrativas discutida por Laville, ela acabou por se constituir em uma atividade onde as informações sobre o governo do presidente Getúlio Vargas foram articuladas a princípio de modo autônomo, uma vez que usavam uma linguagem diferente daquela do material didático, mas algumas reproduções acerca de leituras foram reproduzidas pelos alunos. Ou ainda até mesmo apresentando informações incorretas, ou ainda leituras distintas daquelas veiculadas pelo material didático. Os limites e as possibilidades que esse entendimento do ensino da História oferece serão avaliados.

O currículo e a memória que o ensino de História criou ao longo desses anos de diálogo e reformas interferem não somente na produção dos alunos, mas também no discurso que apregoo como professora, resultado de uma formação universitária específica, e a proposta uma nova linguagem não nos eximiu das armadilhas de seguir uma certa racionalidade forjada na construção de uma história da disciplina, ainda que traduzida em currículo real na sala de aula.

Também na atividade de produção de filmes e na condução desse processo foi construída uma dada realidade em relação ao currículo do $9^{0}$ ano do Ensino Fundamental, uma vez que 
O que as várias correntes teóricas têm disputado, em polêmica cerrada, é a primazia de possuir o melhor critério de tal racionalidade e a determinação que melhor preencha todos os vazios e ocultamentos. Na relação sujeitoobjeto, o sujeito (aquele que pensa e conhece) torna-se a figura central de todo o processo de conhecimento, e este passe a ter como finalidade essencial a instauração e a posse de uma verdade, aceita como objetiva, ainda que seus critérios se mostrem relativos aos quadros cronológicos ou aos juízos do observador (MARSON, 1984, p. 38).

Assim, há um esforço por entender a razão desse objeto se constituir de dada maneira e não de comprovar sua superioridade em relação a outrem.

\subsection{O programa de História nas Escolas Ae B: análises a partir do material didático e do projeto de produção de filmes}

No exercício analítico da atividade de produção de filmes realizados pelos alunos, objeto de estudo desta pesquisa, há ainda uma trama que justifica a seleção e a proposição do trabalho, tanto por parte dos alunos quanto da professora. Para tentar esclarecer os encaminhamentos realizados convém conhecer de que forma o material didático e os planos da escola $\mathbf{1 8}$ em que a atividade foi desenvolvida apresentam a História. Nesse sentido pretende-se chegar a um referencial de partida, diagnosticar algumas informações elementares as quais os alunos tinham acesso e, depois, em capítulo apropriado, verificar suas produções. É certo ainda que o material didático e a narrativa do professor não são a única fonte de pesquisa e de acesso a uma memória histórica, no entanto estas serão nossas referências iniciais, pois o que se pretende

(...) é fazer com que este objeto apareça em todas as suas mediações e contradições, sem que sua evidência manifesta (aparência) e a forma necessariamente parcial de oferecer-se à percepção sejam rotuladas de "falsas" porque estariam em dissonância com um lado "verdadeiro", porém oculto e somente acessível a observadores privilegiados ou ainda "verdadeiro" mas desfigurado intencionalmente por certos "interesses" que manipulam a realidade. É investigar como este objeto foi produzido, tentando reconstruir sua razão de ser ou aparecer a nós segundo sua própria natureza, ao invés de determiná-lo em classificações e compartimentos fragmentados, pelo que "não é", por estar "fora de lugar", ou por ter nascido

18 O material didático utilizado nas escolas que participaram do projeto é de produção local, ou seja, um grupo selecionado de professores escreve o material, sob a orientação do corpo diretivo da escola. 
tardiamente. É finalmente, entender a objetividade como o ato de fazer emergir a trama de relações que tecem a síntese histórica que é o objeto, não uma coisa abstrata (separada) e observada a distância pelo investigador, mas algo que, ao mesmo tempo, contém (e participa de) uma explicação do real histórico, tanto o real do passado quando do presente (MARSON, 1984, p. 49).

Nas escolas em que esta pesquisa ocorreu, a organização do programa do $6^{0}$ ao $9^{0}$ ano segue a história integrada, ou seja, obedecendo a uma sequência cronológica de apresentação dos fatos, inicia-se o currículo de História com conceitos gerais sobre esse saber e o trabalho do historiador. Em seguida desenrolam-se, a partir da lógica do quadripartismo histórico francês, a História Antiga, a História da Idade Média, a História Moderna e a Contemporânea.

Cito a seguir o que tradicionalmente tem constituído e configurado cada um desses núcleos de agregação temática nos programas de História sob a influência da tradição francesa:

História antiga, de fato, história da Antiguidade Greco-romana, com uma tímida abertura para o Egito faraônico e os impérios assírio-babilônicos, Esse período se estende tradicionalmente até a que do Império Romano (conquista de Roma pelos bárbaros, em 410, ou queda do Império Romano do Ocidente, em 484);

História da Idade Média, de fato, da Idade Média ocidental, com um esforço por estendê-la a Bizâncio, ao Leste da Europa e aos países árabes do Mediterrâneo. Esse período se estende até a conquista de Bizâncio pelos turcos (1453) ou até o descobrimento da América por Cristóvão Colombo.

História moderna, sempre da Europa, aí compreendida em sua expansão colonial de ultramar, período que se estende até a Revolução Francesa (1789?, 1799?, 1815?)

História contemporânea, a única que ultrapassa, bem ou mal, o marco europeu e deixa um lugar efetivo para os países da Ásia, África e América (CHESNEAUX, 1995, p. 92-93).

O modelo francês é utilizado tanto na universidade quanto nas escolas do país, mas também apresenta um abrangente efeito na organização de currículos acadêmicos e da Educação Básica no Brasil, exercendo influência inclusive na organização de materiais didáticos. Os efeitos são: uma marcada presença do discurso europeu, enquanto surgem como os portadores da civilização e os realizadores dos grandes feitos históricos.

Uma nova divisão dos temas de História do Brasil é combinada com o quadripartismo francês. Em respeito aos marcos cronológicos e também a certa lógica interna há uma sequência de fatos isolados, os quais são utilizados para conferir uma visão totalizadora da História, de modo que outros acontecimentos são apresentados como 
antecedente ou consequiência desses. As especificidades de determinados eventos históricos se perdem em detrimentos dos marcos constitutivos da História da nação.

Quanto aos manuais de História do Brasil, espero conseguir mostrar um grande ponto comum, a criação de algo semelhante denominado por Gramsci de "a história como biografia nacional", além da reprodução de certos temas, tomados como fatos, persistindo apesar da variação das interpretações. Se seu conjunto forma o passado mítico da nação, esses temas resistem à crítica e continuam a reproduzir-se. Organizam-se como pequenos "nós", pontos centrais, em torno dos quais todo um conjunto de outros temas passa a ser referido. Através dessa rede de relações articulando vários temas em um "nó", cada um deles torna-se definidor e periodizador. O livro didático não os criou, nem os selecionou, antes os reproduziu (VESENTINI, 1984, p. 76).

A criação dos temas que conferem à tradição da História nacional uma característica de elemento agregador também foi explorada na seleção do conteúdo utilizado pelos alunos para a produção dos filmes na sala de aula: o governo de Getúlio Vargas a partir da Revolução de 1930.

Apresento-os: "descobrimento do Brasil", "a independência", "a proclamação da república" e/ou "a abolição", "a revolução de 1930"... Sua articulação sugere continuamente os locais onde as explicações devem debruçar-se com força maior, mantendo o sentido do processo.

[...] Categorias elaboradas, construídas no bojo de processos de luta, a oporem propostas e sujeitos divergentes. Findos aqueles, permaneceram como temas ineludíveis comprometidos com o vencedor e com a dominação. "Revolução de 1930" ilustra magnificamente esse ponto. Em suma, o conjunto forma uma articulação coerente, destinada a projetar uma dada memória - este tem muito, demasiado mesmo, a ver com o poder e os vencedores (VESENTINI, 1984, p. 77-79).

A combinação de temas centrados na divisão francesa e brasileira dos temas de História, apresentados cronologicamente do mais antigo para o mais recente é a História Integrada. Esta também conta com a introdução do tempo sincrônico, que permite estabelecer novas posturas nas relações entre tempo e espaço e entre a História nacional e a mundial. No entanto, constata-se que os conteúdos de História do Brasil são apresentados, na maior parte dessas obras, escassamente.

Mesmo diante dessa possibilidade de ação do tempo sincrônico, não se verifica no material didático utilizado pelos alunos das Escolas $A$ e $B$ nenhuma referência escrita ou proposta de exercício com o objetivo de estabelecer relação entre a história nacional e a européia.

A apresentação da narrativa com as informações históricas segue de modo linear, ainda que haja uma espécie de sequência paralela da História Geral e do Brasil, e a cada novo capítulo uma destas seja privilegiada. Não há no texto do material didático relação explícita 
entre os fatos como se apresentam ordenados. Nesse caso, o tempo sincrônico não é percebido no texto explicativo.

A presença da História do Brasil no currículo adotado nessas escolas particulares e também na maior parte dos livros comercializados deve-se, em grande medida, à História do ensino da disciplina, tal como se verificou na proposição de um panorama do ensino de História.

A organização de conteúdos a partir do modelo integrado coloca os estudos sobre o Brasil em uma posição subordinada à história européia, iniciando apenas no contexto da expansão marítima portuguesa. O efeito entre os alunos é uma adesão modesta aos estudos nacionais, quando comparados aos supranacionais, em especial os europeus. A partir desse modo de operar o ensino de História, a chave para o entendimento do Brasil e sua posição segue uma percepção de que o modo de produção é um caminho de aproximação. Assim, a posição do Brasil é dada por uma leitura da lógica internacional do capitalismo, que o coloca em uma condição de subserviência e atraso, e não dada por fatores internos, ou seja, a MacroHistória é a chave do entendimento - o eixo norteador do conteúdo - e suas explicações de sentido histórico são exteriores.

Esse quadripartismo, todavia, já é inadequado no plano intelectual, inclusive para a Europa e até no interior do discurso histórico clássico. Ele recorta em partes arbitrárias certas zonas históricas homogêneas e originais. (...)

O quadripartismo ainda dificulta o estudo dos fenômenos específicos do tempo longo: a comunidade rústica, a utopia, a guerra não-convencional e os marginais. E, finalmente, chega-se a uma verdadeira doutrinação. Um historiador acaba por se convencer de que só é competente nas sacrossantas categorias de base: será proibida toda reflexão geral e comparada.

Mas o quadripartismo fracassa sobretudo pelo próprio movimento da história. Ele se configura imcompatível com a evolução do mundo e de nosso tempo (CHESNEAUX, 1995, p. 97).

A linearidade de apresentação dos conteúdos não foi quebrada, tampouco debatida com os alunos, mas tentou-se uma atenção a um tema da História nacional. Esse nível de reflexão só foi possível na ação analítica da experiência, de modo que as implicações ideológicas dessa modalidade de organizar o currículo me eram estranhas.

Alerta a professora Circe Bittencourt:

Ao enfatizar-se a integração constante do Brasil a uma História mundial, sem situar devidamente os problemas nacionais e ampliar o conhecimento sobre a realidade brasileira, pode-se reforçar a idéia de que os conflitos internos e seus agentes sociais desempenham papel secundário na construção de uma nação (BITTENCOURT, 2005, p.158). 
Igualmente compromete-se a percepção dos alunos como sujeitos históricos. Há a percepção de um mecanismo opressivo que confere sentido à História, em que a configuração estabelecida é internacional, e a reação interna é sempre de subserviência. A falácia desse modelo de encaminhamento é a construção de um passado como uma narrativa despojada de alternativas, de modo que uma aparente homogeneidade de temas não indica a mesma proposta de interpretação.

A repetição do discurso do livro didático ocorreu na sala de aula durante os dois anos em que o projeto de pesquisa foi realizado. Com o objetivo de seguir as determinações institucionais de cronograma e conteúdos dados, a confirmação de informações foi mantida pela professora. É certo que na exposição algo escapa à linearidade dos fatos, propondo uma lógica interna para determinados processos, mas isso ocorre em exercícios e temas isolados. A produção de filmes, em que os alunos puderam operar com um tema do governo de Getúlio Vargas foi um exercício de autoria, mas o currículo estava lá.

Nas Escolas A e B, os alunos que montaram os filmes estão na última série do Ensino Fundamental. Esse é o ano em que concluem o percurso cronológico dos conteúdos históricos que lhes vem sendo apresentado desde o $6^{\circ}$ ano. Os conteúdos apresentam especial destaque aos eventos da chamada Idade Contemporânea, portanto estudam os temas do século em que nasceram, em especial aqueles generosamente explorados pela mídia, como as guerras mundiais. Das doze unidades que estudarão ao longo do ano, seis delas são dedicadas a temas brasileiros - um empate numérico, mas não na preferência dos alunos. O modelo interpretativo da realidade brasileira é supranacional.

Os conteúdos históricos que serão trabalhados ao longo do ano letivo configuram uma sequência em que os temas da História Brasileira e européia estão intercalados, sem apontar-se, porém, relações entre eles. Observa-se pouca adesão dos alunos frente aos temas nacionais. Um dos objetivos do projeto de produção de filmes era provocar uma reflexão sobre essa questão, proporcionando um entendimento maior da realidade histórica na qual estão inseridos. Ao término de um ciclo de estudos, é pertinente dominar minimamente um repertório de informações do lugar em que se vive.

Com a finalidade de selecionar os temas nacionais a serem trabalhados no projeto, optei não trabalhar com conteúdos que estudariam logo no início do ano, pois queria que realizassem pesquisa, e não pudessem se utilizar do material didático próprio para consultas. As opções eram o governo de Getúlio Vargas e a ditadura militar, mas devido a polêmicas nas interpretações de anos anteriores e a reação de alguns pais de alunos com relação a aspectos desta última, escolhi Vargas. É certo que a preocupação imediata não foi a proposição de um 
exercício que se pretendesse um adensamento da discussão a respeito dos temas da História nacional, mas sim - dentro de uma visão mais pragmática - escolher um recorte que possuísse vasto material para pesquisa dos alunos, sem incorrer na inconveniência de possíveis questionamentos por parte dos pais.

(...) quer se trate de uma aula ou do programa a ser ministrado durante o ano inteiro, percebe-se que o professor precisa mobilizar um vasto cabedal de saberes e habilidades, porque sua ação é orientada por diferentes objetivos: objetivos emocionais ligados à motivação dos alunos, objetivos emocionais ligados à motivação dos alunos, objetivos sociais ligados à disciplina e à gestão da turma, objetivos cognitivos ligados à aprendizagem da matéria ensinada, objetivos coletivos ligados ao projeto educacional da escola etc. (TARDIF, 2000 apud FONSECA, 2008, p. 64) ${ }^{19}$.

A variedade e a quantidade de materiais sobre esse conteúdo, assim como o desfecho do suicídio, também ofereceriam assuntos variados para os alunos tratarem em seus filmes. O recorte cronológico pertinente ao governo de Vargas também possibilitava aproximações com a criação dos governos totalitários na Europa e os efeitos de sua difusão no Estado Novo, e também com a Segunda Guerra Mundial e a participação brasileira no conflito.

Outrossim, a aproximação de alguns conteúdos da História européia com a nacional poderia oferecer um rico campo de possibilidades para a criação dos filmes, assim como gerar uma maior adesão dos alunos à História do Brasil. Essa lógica responde a uma articulação complexa que permite discutir e amarrar temas diversos, apesar das fronteiras nacionais.

Essa seleção compõe um tema-chave para o estudo da História do Brasil, devido aos marcos referenciais que a constituíram - o sentido formador da nação, com um projeto moderno para o país, tendo o presidente um lugar privilegiado nessa narrativa. Os estudos sobre o governo de Getúlio Vargas, em especial na sequência entre 1930-45, trazem uma preponderância do discurso dos vencedores, de modo que a oposição ao local privilegiado do tema é dificultada. Os caminhos para esse feito são dados por uma ação dos historiadores e também pela deliberada ação do comando do Estado Novo (1937-45) em reprimir qualquer discurso contrário ao estatal.

Como professora, também apostei no conhecimento histórico nacional como sentido agregador para o sujeito, o exercício sobre um saber que gerasse a adesão aos

19 TARDIF, M. (2000). "Saberes profissionais de professores e conhecimentos universitários: Elementos para uma epistemologia da prática profissional dos professores e suas consequiências em relação à formação para o magistério". Revista Brasileira de Educação, noำ 13. São Paulo: Anped, jan./ fev./mar./abr., PP. 5-24). 
princípios republicanos e a construção de uma nação. Em minha formação profissional não conheci outro sentido para o ensino de História. Esta pesquisa trouxe novos elementos para refletir sobre esse utilitarismo do saber.

O texto das Diretrizes - documento histórico, produção de historiadores brasileiros - aprovado pelo MEC é explicito: os cursos de história devem formar o historiador, qualificado para o exercício da pesquisa. Atendida essa premissa profissional esta apto para atuar nos diferentes campos, inclusive no magistério. Forma-se o historiador. Sobre a formação do professor, o texto silencia. A produção é uma operação lógica. Certeau (1982, p.70), ao analisar o lugar social da produção historiográfica e o papel dos historiadores na sociedade afirma: "No que concerne às opções, o silêncio substitui a afirmação... Aqui o não dito é ao mesmo tempo o inconfessado de textos que se tornaram pretextos" (FONSECA, 2008, p. 65).

O conteúdo escolhido oferece possibilidades também na ação supostamente paternalista do presidente com a criação de leis trabalhistas, ao mesmo tempo em que escamoteia da ação operária cada uma das conquistas. Até mesmo as operações em que os historiadores ofereceram outra interpretação para a sequência de fatos históricos que compõe os nós de sentido sua nomeação é confirmada. De outro modo, ao trabalhar com os temas do governo de Vargas, particularmente torna-se difícil escapar de determinadas leituras, por exemplo, fala-se da política trabalhista dos presidentes, ainda que se referencie a ação operária.

De acordo com a divisão de conteúdos e a proposta do material didático, o governo de Getúlio Vargas é composto por duas unidades, a primeira denominada Era Vargas $^{20}$, com os limites cronológicos de 1930 até 1945, e a segunda, República Populista e a Redemocratização do Brasil. Nesse caso, o presidente vem acompanhado de outros: Eurico Gaspar Dutra, Juscelino Kubitschek, Jânio Quadros e João Goulart. Há uma breve apresentação das realizações de cada um dos presidentes citados, no entanto a questão conceitual do populismo, anunciado no título da unidade, não é citada.

O formato de narrativa utilizado é uma combinação de informações historiográficas e interpretações textuais para conferir ordem ao conjunto. No entanto, algumas destas vêm acompanhadas de adjetivos que podem induzir a determinadas leituras. Por exemplo, lê-se no material didático sobre a articulação política atribuída aos tenentes na chamada Revolução de 1930:

20 Os títulos das unidades do material didático em que a temática do governo varguista recebia referência foram mantidos. E também eles denunciam a modalidade de aproximação histórica que o autor do texto realiza. A percepção de Era Vargas como um período a ser destacado, e que estabeleceu suas características de modo isolado, sem contudo avaliar o processo. 
Mas embora os tenentes defendessem os interesses populares, também achavam que o povo não tinha preparo nem capacidade para assumir o poder e governar o país. Desse modo, caberia a eles, indivíduos instruídos e patrióticos, assumir as rédeas do país para levá-lo realmente à era da modernidade, atendendo às necessidades e satisfazendo os direitos do povo. Porém, para tornar isso possível, consideravam necessário um governo forte e centralizado (SISTEMA VICENTINO DE EDUCAÇÃO, 1998, p. 75).

Uma característica marcante do material utilizado pelos alunos é a repetição de um conjunto de informações gerais, sustentadas pela tradição do ensino de História. Assim, a sequência de apresentação se dá com os momentos que antecederam ao início do governo de Getúlio Vargas, com algumas informações sobre o movimento tenentista, a criação da Aliança Liberal e a crise da República Oligárquica. A partir do Movimento de 1930 - há aqui a opção por não se usar a palavra Revolução, fato que também marca a adesão a uma corrente historiográfica, norteada principalmente no livro A Revolução de 1930: historiografia e história, de Boris Fausto, em que o caráter de ruptura é questionado -, inicia-se a chamada Era Vargas. Esta encontra-se dividida em tópicos: o Governo Provisório, A Revolução Constitucionalista de 1932, a Constituição de 1934, a Polarização Ideológica, o Golpe do Estado Novo e, por fim, A Crise do Estado Novo.

Outra referência ao governo do presidente Vargas, no material didático, ocorre em uma unidade intitulada República Populista. Em seu texto, não há referência a ou esclarecimento do conceito de populismo. O tópico é apresentado cronologicamente por meio da sequência de cinco governos, indicados pelo nome dos presidentes da República: Eurico Gaspar Dutra, Getúlio Vargas, Juscelino Kubitschek, Jânio Quadros e João Goulart, ainda que o primeiro deles não se enquadre na caracterização de populismo. Para cada um deles há um conjunto de características gerais de sua administração nos campos político e econômico. No caso particular de Getúlio Vargas, além da narrativa dos seus feitos, com destaque iconográfico para a criação da Petrobrás, há a reprodução de sua carta-testamento.

É certo ainda que a presença do professor, conduzindo a aula e propondo o uso do livro, abre caminho para diferentes propostas. O livro não é, necessariamente, o único veículo de informações que os alunos possuem sobre os conteúdos, mas para além dele há o currículo, o qual também oferece força discursiva. Mas no caso das escolas em que o projeto de pesquisa se realizou é a base e o parâmetro para o desenvolvimento das temáticas que serão cobradas em provas. Há liberdade para somar as atividades do livro a outros textos e exercícios, porém a organização pedagógica da escola assume o conteúdo do material didático como o núcleo de suas ações, centrando-se nas informações e não na interpretação que escapa a essa lógica. 
Para desenvolver os conteúdos previstos no currículo, em combinação com o material didático, preparo um quadro explicativo pertinente às informações históricas presentes na unidade. A participação dos alunos é apenas em um suposto encaminhamento lógico das informações. Em geral, este se dá por meio de metáforas, para descrever e associar os processos de modo a viabilizar as respostas na hora da prova.

No modelo do material didático produzido e adotado pelas escolas não há interesse na criação de temas tais como propostas de formação de eixo ou temas geradores para o desenvolvimento de determinados conteúdos. Antes, é apenas uma sucessão de informações e interpretações, expostas cronologicamente.

O exercício de reflexão sobre a prática pedagógica que produziu os objetos empíricos desta pesquisa revela de qual modo o currículo é solidificado nas escolas em questão. Em nenhum momento, tanto da prática escolar quanto nas ocasiões de reunião e encontro dos professores de História, a seleção de conteúdos ou seu formato de apresentação é debatido. A prática docente que tenho também não corroborava qualquer atitude distinta. $\mathrm{Na}$ formação universitária que recebi também experimentei a divisão geral, de acordo com o modelo francês, mas a partir de algumas disciplinas chamadas optativas alguns temas eram explorados, ou alguma especificidade do ofício do historiador tal como em arqueologia. Também realizei diferentes cursos sobre o estudo do cinema e história, favorecendo o trabalho com essa modalidade de documento.

Ao trabalhar com a produção de filmes e com a análise de filmes como objetos na aula de História pretendia construir um sentido explicativo para os conteúdos estudados, a partir da linguagem, mantendo a organização do currículo. A cisão entre forma e conteúdo, porém, não se sustenta, uma vez que há uma união precisa entre eles. Alterar a modalidade narrativa, em alguma medida possibilita uma rearticulação de conteúdos.

A escolha pelo cinema como uma linguagem, e seu referencial visual e simbólico pode operar diferentes mensagens sobre o tema. A adaptação de objetos em personagens trouxe uma leitura paradoxal de uma informação consagrada pelo manual didático, porém na forma permite uma leitura crítica. Mas as conclusões ainda necessitam importantes ponderações, diante dos resultados de criação e os limites que o exercício apresentou.

Usar a linguagem como eixo, e não exatamente o conteúdo, foi uma estratégia tanto para criar um padrão de exercícios de análise quanto para estabelecer um diálogo com os temas que estávamos estudando. Não podia deixar de cumprir os conteúdos propostos para o bimestre, mas talvez fosse possível encontrar uma brecha no interior do próprio sistema. Foi 
necessário combinar conteúdo e forma ${ }^{21}$. Não escapei às armadilhas estruturais da forma e do conteúdo, pois havia uma proposta a ser seguida, estabelecida pela coordenação.

A escolha e seleção dos filmes para análise dos alunos também possuía um duplo sentido: pretendia ao mesmo tempo ser referência na lógica interna do bimestre e um objeto para a análise de determinados elementos fílmicos, uma vez que pretendia oferecer o domínio dessa linguagem aos alunos. Havia ainda o desafio de escolher títulos que os alunos não conheciam, para manter o caráter de surpresa, curiosidade e adesão. Combinado a esse critério, existia outro: iniciar o trabalho com um filme ao qual eles já, possivelmente, haviam assistido muitas vezes, mas no qual não haviam ainda explorados os símbolos, para demonstrar que é possível tecer várias camadas de leitura sobre um mesmo objeto.

Para iniciar as atividades foi escolhido $O$ Auto da Compadecida 22 , em que a temática do universo popular foi o ponto de encontro com os estudos sobre os Movimentos Sociais durante a República Oligárquica. O filme foi assistido na íntegra. Também foi necessário explicar aos alunos e convencê-los - nem todos aceitaram - de que cada título que veríamos era objeto de estudo, ou seja, que não devíamos somente assisti-los; eram cabíveis também intervenções enquanto assistiam, para chamar a atenção para um determinado elemento ou esclarecer alguma dúvida.

O núcleo do currículo em que a Segunda Guerra é baliza temporal sugeriu a escolha de $O$ Grande Ditador. O objetivo era escapar das produções mais recentes, ou das maiores bilheterias sobre o tema. O documentário não foi escolhido por se tratar, em geral, de uma nova exposição factual. Pretendia confrontar dois discursos: aquele dedicado a Hitler e a leitura de Chaplin na construção da personagem Hinkel.

Trabalhamos ainda com animação gráfica, uma vez que a gravação dos filmes deveria usar objetos, e não atores vivos, para introduzir uma modalidade específica do cinema. A escolha foi de um anime, gênero de animação japonesa: Gen pés descalços, em que, além da variação na forma, também havia a alteração do foco narrativo, ou seja, tratavase da visão dos perdedores a respeito do ataque nuclear sobre o Japão, uma subversão do material didático, em que a fala é dos vencedores. A análise do filme pretendia ser um exercício de alteridade.

Dedicamos dois títulos para os temas nacionais e dois para os internacionais. Para o Brasil foram usados filmes no primeiro e no quarto bimestre e, nesse último caso, os olhares

21 A avaliação dos resultados e a descrição mais minuciosa da experiência a ser desenvolvida no capítulo 2.

22 O AUTO da Compadecida, Direção: Guel Arraes. Produção: Daniel Filho e Guel Arraes. São Paulo: Columbia Pictures do Brasil, 2000. 1 DVD. 
já acompanhavam melhor as leituras dos elementos fílmicos, após um ano de trabalho. Ocorreu ainda a produção dos filmes, com exercícios de roteiro - em que a escrita também ganhou um sentido de organizar a ação - a confecção de objetos e cenários, as gravações e a finalização do filme. A fidelidade às informações do material didático deveria ser mantida, ainda que articulada em uma determinada leitura dos fatos.

É provável que o trabalho de análise dos filmes nas aulas tenha repercutido junto aos alunos também por manter a sequência de informações previstas para os bimestres, tal como se o exercício fosse extra. De acordo com os resultados obtidos, não posso afirmar os efeitos da atividade para a relação que os alunos envolvidos no projeto estabelecem com o saber histórico.

No projeto de produção do filme não era objetivo conferir a veracidade de informações históricas, mas diagnosticar as possibilidades de outros discursos, que escapam à narrativa explícita e se expressam nos símbolos que a obra veicula. Porém, para conferir certa justificativa para o uso desse tipo de material, era necessário relacionar explicitamente o enredo e os temas desenvolvidos em aula. Em algumas ocasiões era necessário adiantar determinadas atividades ou trocá-las para que as aulas necessárias para o filme e sua subsequente discussão merecessem espaço. Nesse sentido, em dois dos quatro títulos optei por uma seleção de trechos. Nas duas amostras, os alunos tiveram acesso à continuidade por meio da Internet, em iniciativas próprias.

O papel da História e de seus saberes na escola deve ser localizado e os limites de sua ação demarcados. As aulas e os livros didáticos de História não são os únicos portadores de discursos narrativos sobre o passado, tampouco dessa complexa relação entre as próprias temporalidades. Há um sistema intrincado de relações hierarquizadas de falas. Entram nesse rol de construtores de verdades a família e a organização ética de cada uma delas, de memórias familiares reveladas no cotidiano, bem como as mídias.

É comum, por assim dizer, que nem sempre esses construtores de verdades adquiram para a ciência a mesma legitimidade, no entanto, no cotidiano escolar, essa validade se mistura e cria, como afirmava Benjamin (1994a) camadas possíveis de leitura. A sedimentação de informações justapostas deve elevar o debate. 


\subsection{0 ofício do historiador, o currículo e o projeto}

No fundo, por mais elementar e precária que seja uma aula de história numa escola pobre de bairro de periferia - tomando um exemplo externo - não deixa de ser desdobramento de algum conhecimento bem elaborado nos seus fundamentos e objetivos, do qual o professor recebeu os instrumentos e as condições que o fazem, naquele lugar, o possuidor de algum saber (MARSON, 1984, p. 40).

O ensino de História assume reflexos da produção historiográfica nacional e internacional, de modo que os discursos competentes produzidos nas universidades delimitam lugares para o saber e alteram a consciência própria da disciplina. Além da produção historiográfica, os cursos de formação de professores ou de bacharéis em História apresenta uma configuração específica de leituras capaz de oferecer ao estudante e futuro professor um conhecimento elementar da linguagem e do objeto de seu campo de estudo. Soma-se a essa literatura aquela dedicada aos cursos de licenciatura, com temas ligados à filosofia, psicologia e até à própria História da Educação.

Na própria formação dos professores ou nos cursos de extensão, alguns trabalhos são consagrados, de acordo com uma ou outra corrente historiográfica, de forma que certos autores são privilegiados. Mas qual é a comunicação entre o trabalho do historiador e a sala de aula? Essa interferência se faz presente em alguns materiais didáticos, que acrescentam as novas informações em boxes de curiosidades, sem, contudo, tecer considerações ao sentido narrativo das explicações totalizadoras, comum nessa modalidade de texto. A comunicação aqui se dá na produção da narrativa que compõe os livros didáticos. No entanto, o discurso que o livro didático traz não é único. Ele dialoga com o professor, que seleciona e dá sentido às informações e deste modo a compreensão da História revela dado perfil de atuação.

Há um descompasso entre a produção de conhecimento e a sua divulgação nos livros didáticos. $\mathrm{O}$ ensino de História não se limita a uma transposição dos conhecimentos acadêmicos e pedagógicos, ou seja, não se trata apenas de simplificar os saberes produzidos na universidade, mas de selecionar conteúdos e pensar práticas pedagógicas em uma combinação que favoreça o ensino e a aprendizagem.

No entanto, algumas produções de revistas, preparadas por um grupo de historiadores, tanto com temas nacionais quanto internacionais, viabilizam o contato dos alunos e do público em geral com esses trabalhos, ainda que tenham um objetivo informativo, e não de debate metodológico. Seus títulos são divulgados em bancas de jornal e em grandes livrarias, na seção de revistas, e possui temas e públicos variados. 
Os estudos historiográficos oferecem um conjunto de novos conhecimentos, os quais gradativamente entram para o universo das aulas, tanto como conteúdo e resultado de outras pesquisas, como sendo um debate metodológico. No entanto, sua principal contribuição está nas informações sobre o estudo da História, ou seja, no ofício do historiador. Trazer cada vez mais luz ao modus operandi do historiador favorece a percepção que os alunos possuem da própria área do conhecimento, do sentido e da importância social e pessoal que esses estudos trazem. É, portanto, na Teoria da História que as contribuições são bem vindas. Aqui, a percepção de um corpo teórico cria o sentido de um lugar privilegiado para a reflexão, em que o professor de História encontra a possibilidade de uma seleção de conteúdos e de acesso às idéias pedagógicas.

A identificação do objeto de estudo da História pressupõe a criação de um método de trabalho em que também para os alunos, em sala de aula, o ofício do historiador pretenda traduzir o modo de se aproximar das informações que os livros didáticos trazem. Não se trata, de modo objetivo, de ensinar ao aluno esse ofício, mas sim desnudar o caminho do conhecimento historiográfico e sua transformação em narrativa didática. De todo modo, é o conhecimento na expressão de ensino e aprendizagem o que se pretende.

Neste sentido, a aproximação é com Marc Bloch:

Há muito tempo, com efeito, nossos grandes precursores, Michelet, Fustel de Coulanges, nos ensinaram a reconhecer: o objeto da história é, por natureza, o homem. Digamos melhor: os homens. Mais que o singular, favorável à abstração, o plural, que é o modo gramatical da relatividade, convém a uma ciência da diversidade.

Ciência dos homens, dissemos. É ainda vago demais. É preciso acrescentar: "dos homens no tempo". O historiador não apenas pensa o humano. A atmosfera em que seu pensamento respira naturalmente é a categoria da duração. (...) Realidade concreta e viva, submetida à irreversibilidade de seu impulso, o tempo da história, ao contrário, é o próprio plasma em que se engastam os fenômenos e como o lugar de sua inteligibilidade. (...) Ora, esse tempo verdadeiro é, por natureza, um continuum. É também perpétua mudança. Da antítese desses dois atributos provêm os grandes problemas da pesquisa histórica (BLOCH, 2001, p. 54-55).

A percepção do objeto de estudo da História reflete no percurso que o ensino segue, uma vez que ao assumir, por exemplo: "os homens no tempo" já se estabelece o plural, e a compreensão de uma narrativa histórica dirigida por heróis perde espaço. O tema da construção do tempo também evoca algum diálogo com a aceitação simplista do currículo com sua divisão do quadripartismo francês, que embora seja completado com semelhante segmentação de temas da História nacional, não é linear. Como afirma o historiador, o "tempo da história, ao contrário, é o próprio plasma em que se engastam os fenômenos". Aqui, a 
noção de plasma traz a metáfora de uma densidade do tempo, relativa à sua complexidade de organização, e não de uma exposição cronológica passiva.

Toda essa movimentação resulta de uma atividade também inerente ao trabalho cientifico, ou seja, o desenvolvimento de novas pesquisas, bem como de uma sofisticação metodológica e ampliação de temas e fontes. O avanço da História como um conjunto de saberes cria caminhos teóricos específicos, os quais implicam na historiografia, ou seja, em um modo particular de escrever as informações.

$\mathrm{Na}$ ocupação desse campo chamado saber histórico, o historiador utiliza de instrumentos de trabalho pelos quais define, no tempo e no espaço, algo considerado pertencente ao passado dos homens. Esse objeto é a construção de um tema e uma periodização e caminha na constituição do objeto. Tal resultado é confirmado por uma determinada ação analítica, característica essencial da atividade de pesquisa nessa área. Um objeto não emerge inocentemente do passado. Só é possível conhecê-lo graças a uma perspectiva aberta pelo observador e justamente aqui ele assume um papel decisivo e complexo, e outros pesquisadores se debruçam sobre esses objetos outrora fabricados.

A prática do historiador reencontra a do professor de história. Este acaba lidando com os resultados finais do pesquisador, não importando o atraso de tempo que isto se dê, pois constitui a "realidade histórica" de suas aulas através da historiografia, em casos raros, e dos manuais didáticos, mais frequentemente, que derivam das interpretações. Essencialmente é o mesmo objeto histórico: construído no passado pelo pesquisador e, em seguida, transformado em produto educacional como algo provido de sentido e significado útil, um assunto capaz de suplantar a curiosidade ou mesmo de despertar interesse nas situações do presente (MARSON, 1984, p. 42-43).

O professor, assim como o historiador, fabrica um sentido e cria uma teia de relações capazes de produzir significado às informações. Essa comunicação dialoga com a reprodução da memória do ensino de História, da lógica do currículo, mas como modalidade de saber apresenta uma metodologia, um procedimento de racionalidade, mesmo que o saber e seus objetivos sejam relacionais e, portanto, obedeçam a um dinamismo o qual recebe forte interferência da lógica social e científica na qual está inserido. Ainda assim é possível conferir algumas categorias de entendimento, sem prender-se a uma sequência, para que o ofício do historiador também seja presenciado em sala de aula. Tais categorias são citadas e comentadas a seguir.

Há a noção de processo, que para além de uma referência ao dinamismo de articulação dos fatos, apresenta um sentido narrativo de origem, maturação e superação. Além dele há o desenvolvimento, capaz de sofisticar a noção de progresso, mas com a marca de uma 
etapa, de um caminho, fase ou transição. A justificação dessa movimentação das informações obedece à articulação entre estrutura e conjuntura. Esta põe em curso um fluxo de mudança no tempo entre elementos de longa e curta duração.

A noção de consciente e inconsciente dá conta daquilo que irrompe e da percepção da realidade como cisão do processo, e não do efeito imediato de uma ação premeditada, apresentando um limite nessa relação. O sentido de interno e externo, associado em geral às causas que geram um objeto, revelando uma dupla dimensão constitutiva. A influência atribui significado a partir de analogias simples de semelhança aparente, enquanto o reflexo é um desdobramento da influência 23.

Com essas categorias, o historiador e também professor se aproximam do objeto e com ele interagem, na medida em que propõem ao aluno um movimento de integração entre as diferentes fontes estudadas, adequando um conjunto de informações tidas como verdadeiras, posto que são aceitas dentro de uma metodologia de tratamento. A diretriz para operar o reflexo se dá com a explicação retrospectiva da História. O tema é visto como um resultado definido e faz-se, então, a decomposição de seus elementos, os quais serão generalizados, respondendo ao método indutivo e estabelecendo correspondência com os demais temas propostos no currículo. Uma das modalidades difundidas é a cronologia, ou seja, a sequência temporal que cria uma ligação entre determinados nós em que os marcos se estabelecem. O cientificismo de cada assunto estudado ocorre a partir do suposto distanciamento do objeto, ao submetê-lo a uma teoria, um distanciamento metodológico.

Na aproximação dessa modalidade analítica com a produção e análise dos filmes nas aulas de História pode-se considerar a busca por uma racionalidade do saber tanto para o historiador como para os alunos, uma vez que ao longo das atividades puderam se aproximar dos filmes com um dado objetivo: entendê-lo como portador de um discurso próprio, e não apenas como uma ilustração do conteúdo, ou ainda um entretenimento.

Nesse sentido, existe outra aproximação entre a tarefa do historiador e o modo de operar este projeto: o tratamento de um documento. $\mathrm{O}$ filme aqui passa as ser analisado como um documento, um artefato de cultura, que em sua materialidade própria exige do sujeito cognosceste o domínio de seus elementos constitutivos. Ou seja, operar com um dado documento é dar conta de sua forma, decodificá-lo em sua modalidade narrativa própria.

Os documentos tornam-se importantes como um investimento ao mesmo tempo afetivo e intelectual no processo de aprendizagem, mas seu uso será equivocado caso se

23 Para mais esclarecimentos dessas regras de inteligibilidade ver MARSON, 1984, p.43-47. 
pretenda que o aluno se transforme em um pequeno historiador. Na modalidade de tratamento do documento,

(...) o professor traça objetivos que não visão à produção de um texto historiográfico inédito ou a uma interpretação de um texto historiográfico inédito ou a uma interpretação renovada de antigos acontecimentos, com o uso de novas fontes. As fontes históricas em sala de aula são utilizadas diferentemente. Os jovens e as crianças estão "aprendendo História" e não dominam o contexto histórico em que o documento foi produzido, o que exige sempre a atenção ao momento propício introduzi-lo como material didático e à escolha dos tipos adequados ao nível e às condições de escolarização dos alunos (BITTENCOURT, 2004, p.328-329).

A experiência didática utiliza o exercício como documento a ser analisado, a partir de uma metodologia baseada em roteiros de observação, mas também possui a dimensão de autoria, de modo que são chamados a tomar para si esses procedimentos e anunciar uma interpretação das informações que possuem sobre determinado tema. Essa composição opera em um dupla dimensão: o domínio de determinado conjunto de fatos e a transformação dessa proposta de articulação com os referenciais próprios do cinema. Aqui o documento tem valor de uso, especificidade material e modalidade de produção de discurso.

De acordo com a proposta realizada para essa pesquisa, o filme foi tratado em sua dimensão como documento e este, como tal, responde a um conjunto de características. A primeira é a existência em si do documento, ou seja, os interesses e circunstâncias de sua produção; a segunda é o significado do documento como objeto e seu universo de produção autoral; e a terceira, por fim, é o documento como sujeito, em sua esfera de circulação. Os exercícios analíticos com os filmes eram uma modalidade de saber em que o currículo e o oficio do historiador eram submetidos à reprodução de padrões e saberes já consagrados pela organização pedagógica das escolas em que o projeto se desenvolveu. Para saber a validade e o efeito educacional da proposta é necessário uma compreensão de sua produção e resultados discursivos, tarefa que mereceu destaque no capítulo 4 desta dissertação.

A proposição dessa estratégia de aproximação dos alunos em relação ao conhecimento histórico, usando um documento - e neste caso não é qualquer modalidade, mas sim o cinema -, oferece uma maior adesão às aulas, bem como um espaço para a compreensão do sentido da produção de um saber associado à fabricação de um discurso. É possível esse encaminhamento a partir de produções escritas, mas aqui o filme exigia também um tratamento especial. Esse suporte material do discurso viabiliza também a comunicação com os demais sujeitos do saber, ou seja, com outros alunos, devido à possibilidade de acesso pelo YouTube!. 
Buscou-se o desenvolvimento de uma forma didática, não prescritiva, mas experienciada, para o tratamento do valor documental de um dado objeto e sua relação com outros objetos como a narrativa do livro didático ou da professora. Ao mesmo tempo, essa forma didática desperta o interesse por esse saber e a possibilidade de formação de uma memória. E é a memória que os próprios alunos constituíram dessa atividade, e que em dadas ocasiões comunicaram a outros alunos, o agente que garante o controle do que se deu no passado de cada um. Talvez isso lhes confira o estatuto de sujeitos da História.

Não foi gratuita a afirmação anterior de recomendar exercícios práticos, muito menos se deve pensar na incoerência de separá-los da investigação teórica. Queremos simplesmente ajudar os professores a desenvolver a historicidade a partir das necessidades em ato, das situações vividas e observadas, procurando despertar o sentido histórico já na relação com as coisas mais triviais e imediatas postas no círculo da vida social e do trabalho, em vez de unicamente limitar-se a introduzir o conhecimento histórico a partir da solenidade opaca dos monumentos do passado (MARSON, 1984, p. $54)$.

É certo que o exercício realizado junto aos alunos e descrito no relato de experiência não esgota possibilidades, tampouco se afirma a consciência deles em relação a todo o processo analítico e constitutivo dos filmes, ou mesmo de suas interpretações. Ainda dessa maneira, se aproximaram do oficio do historiador na ação de selecionar informações, transformá-las em uma narrativa dotada de coerência interna e submetê-la à crítica de um público rigoroso - seus próprios colegas.

Por trás da ação dos alunos há todo um conjunto de saberes previstos no currículo, nos livros didáticos e até na fala da professora, mas há ainda uma pluralidade de versões que passa pela percepção da realidade social que possuem e ainda pela realidade de uma aproximação com a linguagem midiática que também possuem. A própria habilidade técnica de utilização de softwares, combinada a uma sensibilidade manual de fabricação de cenário e adaptação de materiais operados simbolicamente, conferem-lhes inteligibilidade. Toda essa articulação é uma produção de conhecimento em que a História foi o tema privilegiado, mesmo que a atividade tenha significação curta para cada educando.

Mas há que se prestar atenção para outra armadilha historiográfica: simplesmente erguer um contradiscurso não garante a chegada ao concreto como síntese das contradições de uma totalidade histórica. É possível que o exercício também tenha criado outra versão do mesmo, ou seja, confirmado a lógica burguesa que estabelece o controle dos movimentos sociais e garante a ascensão de uma elite industrial, submetendo o agrarismo no país. Ainda 
assim, a avaliação da experiência poderia denunciar a perpetuação da simples reprodução de um saber já estabelecido e solidificado pela apatia crítica dos professores e dos alunos.

Nos temas apresentados nos filmes que os alunos produziram, tendo como base o currículo com a apresentação do governo de Getúlio Vargas, a narrativa criada pelos alunos, em geral, confirma as falas dos materiais didáticos, no entanto a possibilidade de autoria e de extrapolação é potencializada pela especificidade da linguagem do cinema, e em alguns casos ocorrem variações. Na operação simbólica da imagem foi possível identificar mais criticidade, em relação ao discurso narrativo propriamente dito. Alguns alunos trabalharam com notícias das informações pertinentes ao governo de Getúlio Vargas, outros com uma interpretação e desconfiança desses fatos, até mesmo alterando a redação da carta-testamento deixada pelo presidente por ocasião de seu suicídio. Essas operações com as informações históricas e a transformação de certa seleção em filme não é resultado de uma consciência pura dotada de autonomia para sobrevoar o real, mas ele se encontra imerso em uma historicidade a ser compreendida. 


\section{Capítulo 3 CINEMA, HISTÓRIA E AS AULAS}

\subsection{Cinema: um breve histórico de seu uso como modalidade narrativa}

Como observa Eric Bentley, o jogo da representação define uma equação mínima pela qual, dentro de certa moldura, A encarna B para o olhar de C (que está fora dela). Apresentada desse modo, a equação é simples mas, em sua acepção mais ampla, ela dá o tom no contexto contemporâneo, pois os dispositivos que articulam o olhar e a cena vão além do teatro, da pintura, da fotografia, do cinema do vídeo e dos modos de composição literária. Envolvem outras formas de relação com o mundo fora de tais molduras, como as interações e os jogos de poder de grande incidência em nossa vida ordinária. A crescente importância da imagem num amplo espectro de atividades e relações é parte constitutiva de uma nítida onda de teatralização da experiência, quando se projeta na cena pública o que antes estava reservado à intimidade, e se define um cotidiano pontuado pelo que já se diagnosticou como "sociedade do espetáculo" (XAVIER, 2003, p. 9).

A teoria do cinema já tem uma história complexa, diversificada, de modo a tornar impossível uma abordagem em todos os seus aspectos, tampouco essa exposição seria necessária para o trabalho que se propõe. O percurso da história do cinema, em que as tipologias estéticas se desenvolveram também não é objeto aqui, no entanto, alguma comunicação nesse sentido se faz necessária para situar em um painel a discussão do cinema como técnica, como uma linguagem específica e seu consumo como artefato cultural. O eixo constitutivo desta dissertação é seu potencial enquanto linguagem que opera a realidade social a partir de uma narrativa própria, que se expande além do roteiro escrito e se articula com a música e o simbolismo da representação, bem como sua veiculação a multidões.

Segundo Bernadet (1986), a primeira exibição cinematográfica pública ocorreu no final do século XIX, na significativa sessão dos irmãos Lumière no Grand Café, em Paris. O que o público viu projetado diante de si foi uma apreensão do real. De modo importante, mesmo sem ter sido esta a intenção e seus criadores, as imagens projetadas criaram tal coerência narrativa que se aproximaram à sensação da realidade.

Este efeito foi conseguido a partir de uma máquina - o cinematógrafo - que se vale do princípio biofísico da retenção de imagens na retina humana para criar a ilusão de movimento a partir da exibição, em alta velocidade, de quadros estáticos.

Neste contexto a ação da burguesia é preponderante - é ela que patrocina este avanço tecnológico -, como afirma Bernadet: 
No bojo de sua euforia dominadora, a burguesia desenvolve mil e uma máquinas e técnicas que não só facilitarão seu processo de dominação, acumulação de capital, como criarão um universo cultural à sua imagem. Um universo cultural que expressará o seu triunfo e que ela imporá às sociedades, num processo de dominação cultural, ideológico e estético. (...) A burguesia pratica a literatura, o teatro, a música, etc., evidentemente, mas essas artes já existiam antes dela. A arte que ela cria é o cinema (BERNADET, 1986, p.15).

Para além destas características técnicas do cinema, a operação da realidade sentida pelo sujeito possibilita uma experiência sinestésica na sessão de cinema. Os filmes não existem só ali, na tela, no instante de sua projeção. Eles se mesclam às nossas vidas, influem na nossa maneira de ver o mundo, consolidam afetos, estreitam laços, tecem cumplicidade. A percepção do cinema define uma característica que é a comunicação por diferentes operações. Esta simples constatação não toma o filme como algo que simplesmente escapa à tela, mas o concebe como elemento vivo, capaz de suscitar o controle ideológico de um determinado grupo, tanto para a sua dominação quanto para a sua libertação. Em toda medida, a ação privilegiada do cinema é constituída historicamente - durante grandes períodos de tempo, a forma de percepção social do filme se transforma; ao mesmo tempo, é um modo de existência, enquanto materialidade produtiva, e também como pertencimento. A maneira pela qual se configura a percepção do meio em que o coletivo está não é apenas condicionada naturalmente, mas também historicamente. A participação crescente da máquina nas relações produtivas, desde a Revolução Industrial, também atinge a construção do real.

A materialidade do filme dialoga tanto com uma sofisticação tecnológica como também com um limite técnico - por exemplo, em suas primeiras sessões, os filmes eram mudos. Porém, a presença da máquina cria, a princípio, um sentido de alteridade da narrativa, qual seja, na mecânica utilizada para a captura e transmissão das imagens não há intervenção da ação humana, portanto não há autoria aparente, de tal sorte que se divulga a garantia da imparcialidade ou neutralidade do cinema. É certo que em discussões posteriores a temática da montagem - como intervenção deliberada de um grupo de operadores técnicos ou artísticos - redefine esse conceito.

A história do cinema é em grande parte a luta constante para manter ocultos os aspectos artificiais do cinema e para sustentar a impressão de realidade. $\mathrm{O}$ cinema, como toda área cultural, é um campo de luta, e a história do cinema é também o esforço constante para denunciar este ocultamento e fazer aparecer quem fala (BERNARDET, 1986, p. 20).

Também há espaço no percurso do cinema como linguagem, para a construção de um conceito de valor de uso para o filme. Foi possível afirmar, em certo momento dos estudos 
sobre o cinema, que seu público era passivo, que recebia de modo indelével toda e qualquer formação de caráter ideológico ao qual as narrativas se prestavam.

No entanto, os estudos sobre o cinema ampliaram esse caráter de recepção do filme pelo público, bem como o lugar que este ocupa perante a obra. Trata-se de uma outra atribuição de significado a essa modalidade narrativa, dada pela capacidade de interpretação do público, bem como pela articulação de seus produtores ou empresas de fomento. Há como que uma alfabetização do espectador, um domínio da linguagem fílmica, uma construção de verossimilhança com o mundo sensível, capaz de provocar adesão a uma mensagem.

Decorre dessa leitura a caracterização de ser o cinema uma linguagem relacional na organização das imagens e na movimentação da subjetividade (XAVIER, 2003, p. 20), ou seja, cujo sentido é atribuído como representação também pelo espectador.

A profundidade e o movimento chegam até nós no mundo do cinema, não
como fatos concretos, mas como uma mistura de fato e símbolo. Elas estão
presentes e, no entanto, não estão nas coisas. Ao dizer mistura de fato e
símbolo, ele [- Musterberg -] se refere à condição do espectador que aceita a
aparência de profundidade e, ao mesmo tempo, sabe esta profundidade não é
real; envolve-se no "como se" da fiçção e guarda consciência de que há uma
convenção que permite o jogo. Ao seu ver, o espectador não é elemento
passivo, totalmente iludido. É alguém que usa de suas faculdades mentais
para participar ativamente do jogo, preenchendo as lacunas do objeto com
investimentos intelectuais e emocionais que cumprem as condições para que
a experiência cinematográfica se inscreva na esfera do estético; para
Musterberg, esfera em que o mundo exterior deve vestir as formas de nossa
consciência. Tal concepção do estético confere ao cinema posição
privilegiada, pois nele, como nunca antes, "o mundo exterior palpável
perdeu seu peso, liberando-se de espaço, tempo e causalidade, e se
revestindo das formas da nossa consciência" (XAVIER, 2003, p.19-20).

O público, como parte integrante da manifestação do cinema, abre caminhos para a compreensão desta expressão como um artefato cultural, e que, portanto, possui uma capacidade de circulação também em sociedades diversas daquela que o produziu, o que o faz adquirir novas decodificações que, enquanto seguem alguns padrões universais, inserem outros, alterando sua significação.

Em relação à leitura da obra cinematográfica há, por assim dizer, a percepção, para o espectador, de que os elementos fílmicos - como o fundo, a profundidade e o movimento - fornecem apenas o material de base para a trama, mas não é só isso que o cinema traz como possibilidade ao longo de sua história como expressão humana. A cena com todos esses elementos -, captura a atenção do espectador, mas seu sentido de realidade desperta um interesse que escapa à mera impressão dos movimentos dos objetos - o sujeito assiste ao filme com a cabeça repleta de representações, o que amplia sua leitura do filme. 
Desse modo, de acordo com Musterberg (2003), estabelece-se uma pedagogia autorizada do espectador, em que a percepção se dá a partir da língua (narração ou trilha sonora) e da imagem. Aqui a atenção é, de todas as funções internas que criam significado no mundo exterior, a mais fundamental, pois é ela que aciona a sobreposição de leituras do filme.

É certo que outras modalidades de documentos históricos também apresentam essa característica específica de tratamento, tal como a cultura material. No entanto, o cinema possui uma peculiaridade em elementos como a edição e a seleção de planos na tela. A fotografia passa por semelhante articulação, no momento em que a realidade é construída a partir da lente do fotógrafo; naquela ação é forjada uma realidade, uma verdade, que também deve ser submetida ao cadinho da análise histórica para que a intencionalidade de sua produção seja evocada e explicitada. O cinema como fotografias em movimento apresenta uma sofisticação técnica, a qual para além do movimento há a trilha sonora, e o espaço de veiculação.

\subsection{Cinema e História}

O passado iluminado pelo cinema é como se Clio, a musa da História, além do clarim e do relógio d'água, portasse também uma lanterna, projetando sobre o passado seu foco de luz artificial (CAPELATO et al., 2007, p. 5).

Desde os primeiros trabalhos de Marc Ferro sobre a utilização do cinema e de sua produção fílmica, os estudos avançaram no sentido de verificar seu status de documento histórico. Assumir o filme como um objeto de estudo é concordar que qualquer reflexão sobre a relação cinema-história toma como verdadeira a premissa de que todo filme é um documento, desde que corresponda a um vestígio de um acontecimento que teve existência no passado, seja ele imediato ou remoto. Soma-se a esta percepção a certeza de que a fonte pode oferecer indícios de resposta apenas quando for interpelada de modo eficiente.

De modo geral, a obra cinematográfica interessa ao historiador na medida em que é um objeto que se comunica com o tempo e o espaço em que foi produzido, isto é, nesta concepção, o passado é tomado como tema direta ou indiretamente. Para o espectador, ao menos aquele pertencente ao grande público não-especialista, o grau de realismo do filme confere uma experiência particular do passado, possivelmente mais livre e atrativa que a escrita historiográfica.

Entre cinema e História, as interferências são múltiplas, por exemplo: na confluência entre a História que se faz e a História compreendida como relação de nosso tempo, como a explicação do devir das sociedades. 
1. Inicialmente como agente da história. (...) 2. Essa intervenção do cinema se exerce por meio de um certo número de modos de ação que tornam o filme eficaz, operatório. (...) 3. É preciso dizer que a utilização e a prática de modos de escrita específicas são, assim, armas de combate ligadas à sociedade que produz o filme, à sociedade que o recebe. (...) 4. Leitura histórica do filme e leitura cinematográfica da história, essa leitura cinematográfica da história coloca para o historiador o problema de sua própria leitura do passado (FERRO, 1992, p. 1319).

O historiador pode tratar um filme de acordo com duas modalidades de abordagem: como documento primário e secundário. Isto é, a obra cinematográfica pode ser tratada como um vestígio tanto da percepção que a sociedade de sua época tinha a respeito do tema tratado no enredo como também das características dessa própria sociedade.

Aqui é assumido que o cinema, como discurso composto de imagens e sons é, a rigor, sempre ficcional, em qualquer de suas modalidades; sempre um fato de linguagem, um discurso produzido e controlado, de diferentes formas, por uma fonte produtora (XAVIER, 2008, p. 14).

Cabe ao historiador identificar a fonte produtora desse discurso, bem como dos elementos que determinaram certo encaminhamento da mensagem. Sendo ficção, o filme cria um discurso sobre o passado, em particular naquelas obras chamadas históricas. Não é o passado como um todo, mas uma ficção sobre ele, que se realiza. Sob essa ótica, até mesmo o documentário oferece ao historiador uma versão da memória histórica.

No processo de tomar o filme - ele próprio - um documento, busca-se não só identificar a ideologia do grupo social que o produziu, mas também o circuito percorrido por essa obra, ou seja, seu valor de uso, para que se passe a outro nível de análise, aquele de caráter subjetivo, que escapa inclusive do diretor. Assim, caracteriza-se o cinema como uma obra coletiva, tanto naquilo que envolve sua produção quanto na operação simbólica de compreensão que os espectadores realizam, uma vez que encontram na tela elementos que lhes atingem.

A aproximação entre Cinema e História, portanto, não deve ser ingênua, esperando que a obra simplesmente reproduza uma dada realidade do passado. Pelo contrário, é exatamente a capacidade de veicular uma narrativa, combinada com elementos simbólicos, que obriga a análise a escapar da linearidade.

A produção cinematográfica não está livre dos condicionamentos sociais de sua época, tampouco pode o historiador afastar-se desta especificidade da linguagem fílmica. Decodificar o documento é dar conta daquilo que é o suporte de sua narrativa, mas nem sempre isso foi uma realidade para os estudiosos em relação ao cinema e à História.

Trata-se do encontro da organização ideológica do filme, à época de sua produção, com sua recepção diante do público de seu período de veiculação. Os filmes ditos 
históricos, ou seja, cujo enredo discorre a respeito de algum acontecimento do passado, frequentemente acabam por dizer mais sobre o seu presente, isto é, sobre a época em que foram produzidos, não obstante seu discurso esteja aparentemente apenas centrado no passado. Isto ocorre porque toda sociedade concebe o enredo e as cenas em função de sua própria cultura. Os filmes não valem somente por aquilo que testemunham, mas também pela abordagem sócio-histórica que eles autorizam.

A apropriação do filme como um vestígio histórico toca em uma questão crucial do ofício do historiador: sua constituição como um documento. Nesse sentido, fica claro que o filme não é a expressão irredutível do fato, tampouco cabe ao historiador lê-lo para a coleta de dados; também não é uma amostragem, ou um relato capaz de confirmar um discurso já pronto (MARSON, 1984, p. 52).

Para a análise do filme como portador de um discurso sobre o passado é necessário seguir três níveis de indagação:

$\left.1^{\circ}\right)$ sobre a existência em si do documento: o que vem a ser documento? O que é capaz de nos dizer? Como podemos recuperar o sentido deste seu dizer? Por que tal documento existe? Quem o fez, em que circunstâncias e para que finalidade foi feito?

$2^{\circ}$ ) sobre o significado do documento como objeto: o que significa, como simples objeto (isto é, fruto do trabalho humano)? Como e por quem foi produzido? Para quem e para que se fez esta produção? Qual é a relação do documento (como objeto particular) no universo da produção? Qual a finalidade e o caráter necessário que comanda sua existência?

$3^{\circ}$ ) sobre o significado do documento como sujeito: por quem fala tal documento? De que história particular participou? Que ação e que pensamento estão contidos em seu significado? O que o fez perdurar como depósito da memória? Em que consistia seu ato de poder? (MARSON, 1984, p. 52)

$\mathrm{Na}$ primeira indagação há uma preocupação a partir da leitura imediata das informações que o documento pode oferecer. Trata-se do nível mais imediato de sua produção, da circulação de sua mensagem. A intencionalidade de sua produção também deve ser perseguida, uma vez que, a depender do público ao qual se destina, temos uma especificidade na forma e também no conteúdo. Um bom caminho para obter-se essa informação é conferir a circulação do filme e seu consumo. A própria existência da obra indicia uma prática social.

Em relação ao filme, faz-se necessária a busca de informações na história do cinema, o que localiza a escola estética e as técnicas empregadas em sua fabricação. Deve-se ainda analisar as relações de patrocínio e consumo do filme e sua materialidade como artefato cultural, produzido por uma equipe. De modo geral, uma obra também se comunica no campo 
de sua linguagem; ela se enquadra em um estilo, em uma forma específica de consumo, visto por mais ou menos espectadores, alterando o alcance da comunicação de sua mensagem.

A materialidade do filme contempla ainda outro elemento relevante: a montagem. De modo geral, na construção de sentido que se pretende há uma seleção de cenas e sequências. A escolha das partes que constituirão o filme oferece ao historiador um caminho para o documento. A partir da montagem pode-se alterar o discurso. Assim, no cinema devemos tomar como elemento analítico a decomposição da cena, mas também a sequência como um todo.

As informações a seguir são fundamentais para a compreensão das propriedades inerentes ao cinema.

1) o documento não é isolado, mas existe em relação a outros que ampliam o seu sentido e permitem maior aproximação com a realidade;

2) este sentido tem referências muito precisas, seja por sua origem, sua autoria ou sua finalidade (sua razão de existir);

3) não é inteiramente explicativo em si, ao lado das significações explícitas tem as implícitas e as não manifestas, tendo o historiador a necessidade de trabalhar (ou, pelo menos, dispor de algum referencial) dentro dele (o que diz) e fora dele (o que representa);

4) não é espelho da realidade, mas essencialmente representação do real, de momentos particulares da realidade; sua existência é dada no âmbito de uma prática determinada; nos dois casos exemplificados, o texto é um ato de poder (lei, processo crime), um código de relação social; age no seu presente; e, em sendo representação, é a fala da prática e parte do real (MARSON, 1984, p. 53).

O documento e o filme, como tal, fazem parte de um conjunto de registro das ações dos homens no tempo, e neste sentido, não devem ser tomados como um discurso uníssono, mas como um recurso potente, com o objetivo de pôr à prova as informações que veicula. No caso particular do cinema, essa referência é ainda mais visível. Seu código próprio de comunicar uma mensagem, bem como sua característica de reprodutibilidade técnica permite uma ação efetiva com o presente.

Para o historiador, operar um documento é dar conta de sua materialidade, de sua linguagem. Cada uma das características materiais do cinema deve ser compreendida para que o entendimento da narrativa contribua na coleta de informações. Não se trata apenas de conferir seu conteúdo, mas de ler seu repertório de representações. Tomar o documento de modo crítico é um compromisso com o rigor, de modo que a reiteração da memória histórica seja colocada em xeque.

Se exercida criticamente, e se o historiador dispõe de amplos recursos teóricos e informativos, esta análise de conteúdo é capaz de revelar uma historicidade contraposta às versões dadas pelos argumentos da memória instituída. Isto quer dizer a possibilidade de recuperar a presença de outros 
sujeitos e outros objetos vencidos e dominados no processo histórico, seja através da contraposição de outros discursos, seja pelo desvendamento das formas de dominação e da figura dos dominados no interior do próprio discurso dominante (MARSON, 1984, p. 53).

Há ainda que se destacar, no caso do cinema como documento histórico, sua especificidade de produção coletiva. Essa tarefa implica uma sofisticada divisão de tarefas, em que o roteirista, o diretor, o operador de câmera, os atores, entre outros, desempenham papéis isolados na construção de um único discurso coerente. As relações entre essas etapas podem oferecer algumas pistas para que o historiador se aproxime de sua capacidade de operar com a realidade social por meio de representações sobre um tempo e um espaço.

Pode-se imaginar que o filme pode oferecer tantas informações sobre sua época e sobre as representações que veiculam quantas forem as vezes que para isto for solicitado, isto por serem inúmeras as possibilidades de leitura de cada obra, variando estas de acordo com a preparação que o analista possui para identificar seus elementos operatórios. Este pressuposto, combinado a um caráter de dinamismo das produções, em que estas vão além de seu conteúdo mais elementar e chegam a escapar àqueles que as produziram - pela razão de que o filme assume seu sentido comunicativo apenas ao encontrar o espectador, o qual também interfere na condução da mensagem a partir de sua capacidade de leitura da realidade ali explicitada -, faz surgir como uma zona ideológica não-visível na comunicação de uma mensagem aparentemente simplificada em relação à produção histórica escrita.

Toda tentativa de análise de um filme implica em uma redução de seu sentido em consequência da impossibilidade de uma análise total e acabada (só alcançável como hipóteses). Todo processo de transformação (que se configura como uma abstração) das imagens em linguagem escrita ou verbalizada leva sempre ao empobrecimento relativo de seu significado (NOVA, 1996, p. 96-97).

Outro fator a ser considerado na relação entre o Cinema e a História é a questão da verossimilhança do enredo. É nesta autorização histórica que a narrativa do filme se sustenta, tornando necessária também, no processo de análise da obra, a atenção ao detalhe, aquilo que é aparentemente banal e quase imperceptível aos olhos do espectador comum, mas que pode garantir ou ao menos indiciar a presença dessa característica no filme.

O tratamento metodológico do filme para estudos de ordem histórica pode ser realizado de acordo com a proposta sistematizada por Cristiane Nova. De acordo com esse encaminhamento, o primeiro passo seria a seleção de título: a escolha segue um princípio de adequação do objeto, entendido como tema, aos objetivos que a pesquisa pretende 
contemplar. Nesse momento, é o conteúdo do filme que deve ser valorizado, em detrimento de seu valor estético.

Após selecionar a obra, cabe sua análise individual. Sua caracterização ocorre a partir do acesso a um conjunto pertinente de informações sobre o filme. Trata-se de conhecer a ficha técnica de sua produção e de sua veiculação, compondo, portanto uma crítica externa do filme. Nesse momento, é possível dedicar-se a uma avaliação do conteúdo, não exatamente no sentido de confrontá-lo com a verdade, mas de identificar os veículos de informação que ofereceram subsídio para a montagem da narrativa. Essa percepção ocorre de modo explícito, ou seja, através dos diálogos, dos gestos, dos enquadramentos, ou seja, dos elementos fílmicos das cenas e do enredo de forma ampla.

No entanto, como já foi dito anteriormente, o filme não é uma modalidade discursiva que opera pelo óbvio, pela simples decodificação de uma sequência de símbolos decifráveis. Devem-se também analisar os elementos implícitos no enredo, associados a um conteúdo acessado em camadas mais profundas de leitura, variável de acordo com o repertório do espectador. A análise dos elementos implícitos e explícitos da cena está também associada à intenção dos produtores.

Como procedimento exigido pelo ofício do historiador é necessário estabelecer uma comparação entre os resultados encontrados após a análise dos filmes e os fornecidos por outras modalidades de fonte. É certo que esse proceder também se aplica à utilização de filmes na sala de aula, uma vez que a construção da racionalidade empregada pelo historiador também torna possível o acesso do professor e do aluno à obra.

Não convém igualmente ao analista ficar atento somente ao conteúdo histórico que o filme veicula; ele difunde um saber, o qual não necessariamente coincide com ou mesmo está contemplado pelas informações consagradas pela historiografia. O filme, por ser um produto de comunicação de massa, opera com uma autorização de comunicar uma mensagem ao público, que é característica da própria constituição do Cinema, e o historiador com seu rigor metodológico denuncia os supostos falseamentos realizados. Utilizar este recurso nas aulas pode contribuir para o desenvolvimento de uma leitura cinematográfica da História, que seja eficiente e formadora de conhecimento científico e consciência histórica.

Os referentes históricos de um filme histórico podem ter várias origens: a historiografia escrita, a mitologia, o conhecimento histórico popular, uma pesquisa própria do cineasta e, o que é muito importante, sobretudo para o cinema dito comercial, a concepção da história (simbólica audiovisual e de conteúdo) do espectador - que tem sido moldada, ao longo da sua existência, pelos elementos referenciais enunciados acima, mas também pelo próprio 
cinema que acaba, pelo processo de repetição, criando modelos históricos específicos (NOVA, 1996, p. 101).

A criação de um recorte temático para a constituição de um enredo, bem como a organização de seus elementos cênicos, pode ser ditada pelas vicissitudes do presente. Por exemplo, retornar ao passado como tema pode funcionar para ocultar um conteúdo presente, e que se deseja passar para o espectador.

Assim, o estudo do filme para a História não perde de vista a relação passadopresente e a capacidade privilegiada que o cinema possui de representar o passado, seja como objeto de seu tempo, seja como apropriação de determinadas verdades.

Partir da imagem das imagens. Não buscar nelas somente ilustração, confirmação ou o desmentido do outro saber que é o da tradição escrita. Considerar as imagens como tais, com o risco de apelar para outros saberes para melhor compreendê-las. Os historiadores já recolocaram em seu lugar legítimo as fontes de origem popular, primeiro as escritas, depois as nãoescritas: o folclore, as artes e as tradições populares. Resta agora estudar o filme, associá-lo com o mundo que o produz. Qual é a hipótese? Que o filme, imagem ou não da realidade, documento ou ficção, intriga autêntica ou pura invenção é História. E qual o postulado? Que aquilo que aconteceu (e por que não aquilo que não aconteceu?), as crenças, as intenções, o imaginário do homem são tão História quanto a História (FERRO, 1992, p. 86).

O cinema coincide com a História em mais um aspecto: a sua capacidade de produzir sentido e de comunicá-lo. A construção de sentido é dialética e se dá na relação do processo de análise de cada sujeito na sala de projeção e, em outro momento, na análise realizada pelo historiador. Além disso, o processo de criação do filme é subjetivo e não constitui um mero reflexo social. O método analítico deve buscar elementos da realidade através da ficção.

Aproximar-se dos estudos do cinema como um documento que veicula uma contra-história da sociedade não é relegar o papel do historiador a um segundo plano. Antes, abre possibilidades de entendimento da pluralidade de elementos discursivos e de sua articulação de sentido por aqueles que são os sujeitos da história - os produtores, os espectadores, enfim, os homens no tempo.

\subsection{O Cinema na sala de aula}

O que transforma o documento em monumento é, no fim das contas, a sua utilização pelo poder; não existem, a rigor, documentos ou "registros puros" - são as perguntas que fazemos ao documento que o transformam em tal condição, ou seja, tudo depende da nossa construção, da forma como 
recortamos nosso objeto. Isto pode ser talvez ainda mais válido no caso do material fílmico, que trabalha com imagens capazes de provocar um efeito de realidade mais ou menos forte, mas certamente desconhecido dos signos verbais. (SALIBA, 1993 p. 96-97)

O uso do filme enquanto recurso didático não é uma atividade recente no Brasil. No entanto, os trabalhos que versam sobre sua utilização em sala de aula variam no enfoque. É possível verificar, no país, já na década de 1930 alguns estudos sobre a questão, contando inclusive com uma literatura específica em que o cinema é proposto como instrumento de ensino, viabilizando a comunicação das informações necessárias aos alunos, revestida de verdade pela técnica, e também como ícone da modernização do país.

Diversos intelectuais ligados à corrente educacional da Escola Nova, na década de 1930, a exemplo de Fernando Azevedo, Francisco Campos, Afrânio Peixoto, Anísio Teixeira e Edgar Roquete-Pinto, dentre outros, já apontavam o forte potencial do cinema na educação das crianças e jovens da época. Como podemos perceber nos livros de Joaquim Canuto Mendes de Almeida, Cinema contra cinema: bases gerais para um esboço de organização do cinema educativo no Brasil e de Jonathas Serrano e Francisco Venâncio Filho, Cinema e educação. A revista Escola Nova (n. 3), uma publicação da Diretoria Geral do Ensino do Estado de São Paulo, em julho de 1931, publicou um dossiê com diversos artigos dos mais renomados educadores (Manuel B. Lourenço Filho, Agenor de Roure, Jonathas Serrano, Francisco Venâncio Filho, dentre outros) todos enaltecendo as possibilidades didáticas e pedagógicas do cinema (NASCIMENTO, 2008, p. 3).

Soma-se à atenção de um grupo de intelectuais com o uso do cinema uma forte interferência do agenciamento estatal na produção de filmes, ou seja, havia um interesse na formação de um acervo a partir do qual as prescrições de utilização e condução de uma modalidade específica de caráter nacionalista, típicas da década de 1930, estivessem presentes. A forte participação do Estado no patrocínio da produção cinematográfica apresenta uma serventia pela qual a História oferecia um suposto eixo de suporte para a comunicação, aos brasileiros, de uma realidade do país. Nesse contexto, em 1937, foi criado o Instituto Nacional do Cinema Educativo (INCE), dirigido por Edgar Roquete-Pinto. Sob essa orientação se produziram e distribuíram, nas escolas, centenas de títulos. O INCE foi extinto em 1967, para o surgimento do Instituto Nacional do Cinema, com objetivo semelhante.

Sob a orientação do INCE, tanto a produção de filmes quanto a literatura a esse respeito se caracterizaram por uma proposta de constituição do discurso cinematográfico como uma ilustração da realidade nacional, a partir de uma narrativa ordenada por intelectuais 
e diretores ligados ao Estado. O caráter ideológico dessa atividade pretendia reforçar a adesão ao projeto patriótico. A potencialidade do cinema, neste caso, corresponde a uma modalidade discursiva com a característica específica de veiculação para as massas - as imagens e o som alcançando um público maior, em relação àquele atingido pela informação meramente escrita.

$\mathrm{Na}$ produção de filmes do INCE há uma escolha pela produção de caráter documental, por exemplo a exibição de imagens de manifestações públicas, combinadas com a forte interferência da fala de um narrador, cuja função é comunicar determinadas informações sobre o tema. Esta sofisticada combinação confere ao material uma unidade discursiva em que a crítica é preterida. A atenção desse conjunto de intelectuais que refletem e elaboram propostas de uso desse recurso/modalidade discursiva não é a alfabetização do olhar do sujeito para a imagem, mas a divulgação de uma mensagem. Assim, o Estado assume um viés de produtor e emissor de suas próprias opiniões diante do público, nesse caso, ainda maior em número devido ao caráter de reprodutibilidade técnica do cinema. Mas é na sua característica fílmica que ele escapa do controle total do Estado e da censura, uma vez que o filme traz à tona uma tensão que lhe é própria, com a articulação de elementos que viabilizam uma análise da sociedade a qual é diversa daquela proposta pelos seus segmentos - tanto o poder constituído quanto a sua oposição.

Este quadro sofre interferência a partir da década de 1980 quando alguns historiadores entram na discussão, e esclarecem o sentido de documento histórico que o filme possui, embora esse debate já se fizesse presente nas primeiras décadas do século XX, entre os próprios estudiosos. É na reflexão sobre o uso didático dos filmes que se destacam algumas produções, tais como: Cinema e História (FERRO, 1992), Como usar o cinema em sala de aula (NAPOLITANO, 2006), e alguns tópicos de O saber histórico em sala de aula (BITTENCOURT, 2005), entre outros.

Desse modo, a utilização do cinema, particularmente nas aulas de História, converge para alguns debates acerca da própria natureza do oficio do historiador: de acordo com os PCNs (BRASIL, 2000), a História é apresentada como um conjunto de saberes apreendidos com o domínio de competências e habilidades e o conhecimento de diversos tipos de linguagem audiovisuais.

A variedade tipológica das fontes usadas no ofício do historiador chega em alguma medida às atividades escolares, nascendo então um conjunto fértil de produções didáticas, com características prescritivas para a utilização dessas linguagens e de suas relações com o ensino de História. 
O tema da modalidade de linguagem - o uso do cinema, da televisão, da música, do jornal, e outros mais no ensino de História -, se comunica também com o papel do sujeito na recepção das informações fílmicas. As características de documento que estas linguagens possuem - sua materialidade e a interação subjetiva com o espectador - propiciam um conjunto de análises ainda mais complexas.

É por esse caminho que segue a produção de um conjunto de publicações da Fundação para ao Desenvolvimento da Educação, ligada à Secretaria de Educação do Estado de São Paulo, na década de 1990. Trata-se da coletânea Lições com cinema (FALCÃO, BRUZZO, 1993). O material propõe uma metodologia para o tratamento do filme como uma fonte de conhecimento, a ser destrinchado na forma e no conteúdo por diferentes áreas do saber. No caso específico de História há a produção de Elias Tomé Saliba (1993, 2004, 2007) sobre a produção do conhecimento histórico e a narrativa fílmica, em cujos textos estão exemplos de um conjunto de procedimentos de decomposição, análise e interpretação de filmes.

(...) A construção da história na ficção fílmica é mais do que uma interpretação da história, pois o ato de engendrar significados para o presente lança o realizador (ou realizadores) da ficção cinematográfica em possíveis ideológicos que ele não domina em sua totalidade. Portanto, construir a história na narrativa fílmica pode implicar, inclusive, destruir significados estáveis, desmontar sentidos estabelecidos, desmistificar ilusões ou mitos já cristalizados - seja pela tradição, seja pela própria historiografia (SALIBA, 1993, p. 103).

Porém a abordagem desta linguagem na sala de aula é feita frequentemente de maneira pragmática, dando ênfase à utilização de sua tecnologia, sem propor um debate a respeito de seu impacto no ensino de História, bem como de sua relação com o ofício do historiador. A tecnologia é utilizada como panacéia para a viabilização do saber, com a distribuição de kits contendo aparelhos de reprodução de mídias nas escolas públicas do país, em combinação com as recomendações dos PCNs, a partir de 1997.

\subsection{Modos de uso do cinema no desenvolvimento da pesquisa}

A leitura depende da escuridão da noite. Mesmo que se leia em pleno dia, fora, faz-se noite ao redor do livro. Assim, mais do que mera substituição ao mecanismo textual do livro, do espetáculo ou de qualquer outro produto cultural, o assistir é, como disse Michel de Certeau, um ato de espreitamento, uma viagem de nômade, sem paradas obrigatórias. O 
telespectador lê a paisagem de sua infância na reportagem de atualidade; por menos que se queira, o espectador cria uma espécie de cena secreta, lugar onde se entra e se sai à vontade: é ele quem cria, afinal, cantos de sombra e de noite para a existência submetida à transparência tecnocrata. (SALIBA, 2004, p. 119).

No sentido de analisar a experiência pedagógica aqui descrita, há que se considerar as duas atividades desenvolvidas no projeto: uma com exercícios de análise de determinados filmes, com o objetivo de propor certa alfabetização do olhar diante das especificidades da forma discursiva do cinema - etapa essa destinada a todos os alunos do $9^{\underline{0}}$ ano - e outra que toma a característica específica do cinema como forma de organizar e veicular uma produção autoral discente - esta última foi realizada apenas por um conjunto de alunos, que aderiu à proposta, porém, ao final, as produções foram submetidas à crítica de todos os alunos, que a essa altura já haviam tomado contato tanto com os elementos de análise de filmes como com o tema que norteou a elaboração do enredo.

A pesquisa dialoga com uma percepção de que tanto o historiador quanto o professor, em seu ofício, se deparam com um fenômeno inusitado: a transformação do acontecimento em imagem em movimento. Não mais aquela imagem alegórica que narra e ilustra os fatos com percepções mecânicas da realidade social, mas a imagem alegórica que mostra e alude a novas representações (SALIBA, 2004). Os efeitos dessa operação podem ser percebidos pelas reações dos alunos diante da proposta, descritas oportunamente no relato de experiência, nas quais se multiplicam as comunicações entre as próprias representações.

Essa configuração não significa, no entanto, fechar todas as outras vias de interpretação e de produção de sentidos internos e externos ao saber histórico, esquecendo-se de que o filme possibilita, sobretudo, abrir portas para a elaboração simbólica, as criações e camadas de leitura pessoais, que são um caminho para a invenção política e social.

Na primeira atividade, a seleção dos títulos passou por critérios mais ou menos objetivos, dependendo dos conteúdos que estavam sendo estudados na época. No primeiro filme, por exemplo, era necessário que os alunos tivessem acesso físico à obra - os exemplares deveriam ser encontrados facilmente em locadoras - e seu enredo e forma deveriam conter elementos que fossem ao encontro dos interesses das turmas.

Os filmes selecionados foram então analisados sob a ótica de seus conteúdos e suas formas, sendo que no conteúdo o foco da análise foi sobre o discurso apresentado, entendido como produto de uma determinada época e sociedade, enquanto que na questão da forma, foram explorados elementos de montagem, enquadramento, trilha sonora, simbolismos 
da cena, personagens etc., a maneira como se comunicam com o discurso e a percepção que revelam de características dessa sociedade que produziu o filme.

O objetivo foi criar um exercício no qual os alunos pudessem apreender determinadas características da análise de filmes ao mesmo tempo em que manipulavam os elementos dessa linguagem para realizar suas próprias produções. Por este motivo, em nenhum dos títulos a confirmação ou não das informações históricas foi perseguida como foco, embora tenha sido esclarecida, ao surgir como dúvida dos alunos.

O mesmo procedimento foi aplicado para a análise dos filmes produzidos pelos alunos - o foco não era exatamente verificar a apropriação do conteúdo sobre o governo de Getúlio Vargas mas, sim, identificar as possibilidades de produção de um sentido que emerge da estrutura do filme. Este sentido possui um movimento que lhe é próprio, e relaciona-se com a dinâmica de desenvolvimento do enredo, juntamente com os elementos de cena. É importante, portanto, para que possamos apreendê-lo, refazer o caminho trilhado pela narrativa e reconhecer o contexto onde se desenvolve, a fim de compreender as opções que foram feitas e as que foram deixadas de lado no decorrer do processo de sua elaboração.

O relevante ou irrelevante não é um dado que a priori podemos estabelecer na análise fílmica a partir de nossos conhecimentos anteriores. Com esse movimento, evitamos o emprego da História como pano de fundo, na medida em que o filme não está a iluminar a bibliografia selecionada, ao mesmo tempo em que não isolamos a obra em seu contexto, pois partimos das perguntas postas pela obra para interrogá-lo. Dessa forma, impedimos que o cinema seja sufocado pela pesquisa histórica, mantendo o "enigma inicial" da película de que fala Serge Daney (MORETIN, 2007, p. 63).

Os filmes foram utilizados nas aulas, portanto, como objetos de estudo para se percorrer as possibilidades de construção de uma determinada narrativa. De acordo com Xavier24 (1997 apud MORETIN, 2007, p. 63), na análise do filme encontramos uma "pluralidade de canais", que são: "o olhar da câmera, a organização do décor e da mise-enscène, emoldurados pelos agenciamentos de imagem e som feitos na montagem”.

Uma vez estabelecida a opção por não tratar o filme como uma ilustração daquilo que se estava apresentando, não se poderia ter como alvo do trabalho o confronto direto do enredo com as informações históricas contidas no material didático. Até mesmo o formato de exibição dos filmes se afastou desse encaminhamento de apresentação alternativa das informações por outro meio que não os textos: em apenas duas ocasiões ao longo do ano letivo os alunos assistiram ao filme na íntegra - no primeiro e quarto bimestres, com $O$ Auto

24 XAVIER, I. O olhar e a voz. A narração multifocal do cinema e a cifra da História em São Bernardo. Literatura e Sociedade. Revista de Teoria Literária e Literatura Comparada, (2): 130,1997. 
da Compadecida e $O$ Ano em que meus pais saíram de Férias ${ }^{25}$; nas demais, foram exibidos apenas trechos de interesse, explicitando um recorte na narrativa e permitindo maior atenção na exploração e análise dos elementos constitutivos da forma cinematográfica. Dentro desta abordagem de caráter didático, visando uma sensibilização e uma alfabetização do olhar dos alunos para a leitura da imagem em movimento, durante as exibições, foram feitas várias intervenções, pela professora, chamando a atenção para elementos importantes da linguagem fílmica, por vezes ocultos nas cenas.

Todas essas interferências foram feitas no sentido de irem ao encontro de uma constatação:

É certo que hoje se admite que a imagem não ilustra e nem reproduz a realidade, ela a constrói a partir de uma linguagem própria que é reproduzida num dado contexto histórico. Todas as definições, mesmo as mais notáveis, tendem a retirar o filme do terreno das evidências - ele passa a ser visto como uma construção que, como tal, altera a realidade através de uma articulação entre a imagem, a palavra, o som e o movimento. Os vários elementos da confecção de um filme - a montagem, o enquadramento, os movimentos da câmera, a iluminação, a utilização ou não da cor - são elementos estéticos que formam o que chamamos de linguagem cinematográfica. (...) A análise do filme não se resume nem à intenção do diretor nem à análise do conteúdo do filme a partir do seu roteiro. Ao contrário, ele deve ser examinado como um trabalho acabado - na sua combinação de elementos visuais e sonoros - e pelos efeitos que produz (SALIBA, 2004, p. 119).

Nas escolas A e B a percepção das modalidades de ensino veiculadas tanto no material utilizado como nas provas encerra uma utilização da imagem como ilustração e não como objeto de conhecimento, ou seja, uma fonte que exige daquele que a lê a criação de determinada metodologia analítica, fazendo a atenção voltar-se para o seu lado mais invisível, frágil, onde talvez se encontrem os possíveis vestígios de um inconsciente visual da época e de uma narrativa histórica que está nas escolas em que o projeto foi realizado, ainda que não seja possível criar um mapa de sua origem narrativa.

Para efetivar a apreensão do filme a ser lido, ele também foi objeto de rememoração, ou seja, os alunos nas aulas subsequentes à sessão eram chamados a responder por escrito a um roteiro de análise. Este explorava a visualização técnica da produção e seguia uma combinação de propostas de reflexão sobre a forma e o conteúdo. Algumas afirmações interpretativas foram feitas com o objetivo de verificar a coerência interna do discurso e a construção de um sentido de verdade.

25 O ano em que meus pais saíram de férias. Direção: Cao Hamburguer. Buena Vista, 2006. 
A verificação da eficiência dos exercícios se dava com o desenvolvimento da atividade seguinte; pôde-se notar um amadurecimento da participação dos alunos nas interpretações das perguntas e na formulação de suas repostas, em especial na sua articulação oral - notou-se que as respostas escritas foram por demais lacônicas, em sua maioria. De todo modo, foi necessário intervir intensamente na elucidação dos exercícios propostos, tanto naquilo que se refere ao vocabulário, quanto na percepção dos elementos das cenas. É certo ainda que não houve esgotamento das possibilidades da proposta.

A acumulação dessas percepções e o domínio das informações e da estética do filme tiveram um momento singular de aplicação, que ocorreu no final do ano, na projeção dos filmes que os colegas produziram. Em cada avaliação que faziam eram instigados a sustentarem com alguma referência a forma. Notou-se que alguns alunos participaram com mais segurança, em relação a outros. Para Xavier (2003), no cinema, o espectador é separado do mundo palpável, ele perdeu seu peso, libertando-se do espaço, tempo e causalidade, e vai se revestindo das formas de nossa consciência.

Nos exercícios de análise dos filmes, perder o peso significa não depositar no enredo o foco, ou seja, não operar com a ilustração de um tema histórico, ou ainda sua expressão no formato do currículo. A libertação do tempo é a percepção da cisão entre o momento temporal em que o filme foi produzido e aquele o qual representa.

No caso de $O$ Grande Ditador, a retratação da guerra não é colorida, mas a realidade vivida pelos soldados no conflito sabidamente o foi, há uma denúncia de pertencimento a um outro tempo. Dessa forma, o elemento acionado é uma espécie de memória por aproximação formativa, exigindo do aluno a evocação de informações que caracterizem o episódio histórico ao qual o filme faz referência.

Nas obras cinematográficas analisadas pelos alunos em cada um dos bimestres o ordenamento do tempo como algo linear, apresentando na sequência passado, presente e futuro, se altera. O tempo deixa de ser uma simples representação cronológica, pois ele é esticado pelo efeito da câmera-lenta. Também se introduz um tempo da consciência, em que os eventos assumem o curso afetivo do personagem. Até mesmo o fio da causalidade discursiva se altera, dialogando com outras percepções sobre o tempo. Nessa combinação, a condução do filme $O$ ano em que meus pais saíram de férias sofre uma suspensão para explicar ao telespectador a morte do avô de Mauro - o personagem que narra o filme - e seu destino, informações elementares na trama. Esse exercício vai de encontro com os princípios da racionalidade do saber, ou seja, cria um encadeamento dos fatos, de modo a gerar uma unidade que faça sentido. 
A opção pela escolha do cinema e da especificidade do tratamento dos elementos fílmicos tinha como objetivo também provocar determinada adesão dos alunos às aulas de História, de modo que o apelo ao uso da tecnologia propiciasse um maior envolvimento e atenção à proposta. Tornar o cinema objeto de estudo também era recorrer à sua função de lazer, comunicação e cultura de massa, porém concedendo a esta atividade, que praticam de modo corriqueiro, um outro status de valorização. O cinema como obra de produção coletiva o era também na constatação de que a professora também assistia a ele e selecionava os títulos para utilização nas aulas, mesmo aqueles que já haviam sido veiculados na televisão, como é o caso de $O$ Auto da Compadecida e $O$ Grande Ditador.

É preciso levar em conta uma situação muito peculiar a todo espectador de cinema, que ocorre em maior ou menor grau: "O cinema é sempre ficção, ficção engendrada pela verdade da câmera (...) o espectador nunca vê cinema, vê sempre filme. O filme é um tempo presente, seu tempo é o tempo da projeção. Esta característica implica uma reação muito empática do espectador com o filme que assiste. A tendência é que o aluno (e mesmo o professor) reproduza uma certa situação psicossocial trazida pela experiência na sal de projeção (ou na sala caseira de vídeo) para a aula. Portanto, é preciso que o professor atue como mediador entre a obra e os alunos, ainda que o professor atue como mediador entre a obra e os alunos, ainda que ele pouco interfira naquelas duas horas mágicas da projeção (NAPOLITANO, 2006, p. 14).

$\mathrm{Na}$ experiência pedagógica, a linguagem cinematográfica também ofereceu o formato da modalidade narrativa. Somou-se à realidade de análise de obras a criação de um trabalho autoral, ou seja, um filme, através do qual um grupo de alunos pudesse comunicar aos demais sua mensagem. A produção dos filmes - para aqueles alunos que aceitaram esta proposta - se configurou como uma atividade paralela às demais do programa regular, ao mesmo tempo sem que pudessem contar com o espaço físico da escola para a sua realização técnica. Como um caminho para subsidiar essas questões, analisávamos outros filmes e estudávamos em aula os temas. A questão do desenvolvimento da forma, do conteúdo e de sua articulação funcional contou apenas com o destaque para obras já prontas.

O eixo favorável que surge do desenvolvimento da percepção discursiva dos alunos é a possibilidade de escolherem determinado caminho na condução de sua narrativa. É certo que a escolha que os alunos realizam não é gratuita, ou seja, obedece a um conjunto de regras e especificidades pertinentes à composição de coerência na obra. A combinação do uso do filme como objeto de análise, durante sua veiculação, e como uma modalidade discursiva pretendia despertar a sensibilidade dos grupos envolvidos no projeto para essas características, e seus possíveis usos na produção que estavam realizando. 
A seleção de um recorte temático era um desafio diante do conjunto de informações que possuíam, a partir de pesquisas na Internet ou consultas ao livro didático. Esse recorte de conteúdo não é um exercício comum na prática autorizada aos alunos nas escolas A e B. Em geral, essa escolha é realizada pelos professores em um contexto de preparação para uma prova. Também os critérios de seleção empregados nessa tarefa deveriam levar em conta seu potencial como viabilização da imagem. A escolha do tema dentro do universo das informações sobre Getúlio Vargas foi realizada a partir do domínio dessas informações, e também pela força da mensagem.

O crivo pessoal ressoa com vigor na seleção temática - aqui é possível identificar as representações que os alunos possuem dos temas estudados e também aquilo que gerou significado na aprendizagem do aluno responsável pela elaboração do roteiro. Embora as atividades tenham sido distribuídas entre os integrantes do grupo, tal como a produção coletiva no cinema, todo o conjunto se envolveu na seleção dos temas. A tarefa do roteirista foi a formalização da escolha, após algumas conversas sobre a transformação da proposta nas cenas. Mas há ainda seleção por parte do diretor, aquele que comanda o enquadramento da cena e as transformações dos elementos em mensagens dramáticas. E, por fim, também, há a atividade do aluno que finalizou o filme - aquele que escolheu a trilha sonora, os créditos, com suas cores e formas.

Este trabalho de seleção seria perdido se não fosse combinado com um encaminhamento interpretativo eficiente, que demonstrasse coerência narrativa. Para que essa construção de sentido ocorra faz-se pertinente que os alunos operem o conteúdo escolhido, em relação à linguagem que escolheram. Torna-se igualmente importante a constituição da materialidade dos personagens, dos cenários e demais elementos cênicos. Aqui a eficiência do discurso é alcançada também pela sua verossimilhança, ou seja, há que se utilizar signos que sejam reconhecidos por outros espectadores e que possam referenciar conhecimentos já aceitos - esta aparência de verdade, criada a partir da coerência interna do filme, passa pela interpretação das informações que já receberam.

No auge do processo criativo de produção do filme, a articulação com a seleção, a construção material dos espaços e personagens, bem como da trilha sonora é submetida a uma espécie de exame de eficiência do discurso no momento em que os filmes são apresentados em sessão aos demais alunos.

Ao abrir o filme à comunicação aos demais alunos da escola - e ainda à outra escola -, cria-se um caráter avaliativo e até mesmo de adesão ao projeto realizado pelo grupo. A eficiência do discurso combinado com a forma eliminou o caráter apenas pessoal dos 
comentários realizados pelos alunos durante a sessão. A postagem das obras no portal YouTube! abriu ainda mais as possibilidades de comunicação, podendo resultar, ainda, em comentários de outros espectadores.

A produção de filmes nas aulas de História, bem como sua utilização como modalidade discursiva para a organização de uma mensagem de autoria discente pretendeu testar o potencial narrativo para o qual Walter Benjamin nos chama a atenção:

Seu objetivo é tornar "mostráveis", sob certas condições sociais, determinadas ações de modo que todos possam controlá-las e compreendêlas, da mesma forma como o esporte o fizera antes, sob certas condições naturais. Esse fenômeno determina um novo processo de seleção, uma seleção diante do aparelho, do qual emergem, como vencedores, o campeão, o astro e o ditador (BENJAMIN, 1996, p. 183).

Procurou também fugir da verificação de informações sobre o passado, ocupandose mais em verificar a articulação entre esses dados - e a forma cênica - com os elementos específicos do cinema. O status - ou a validade dos filmes produzidos pelos alunos - não foi submetido à autenticidade do documento histórico, em que se constituiu, de modo que é pertinente a orientação:

Se não conseguimos identificar, através da análise fílmica, o discurso que a obra cinematográfica constrói sobre a sociedade na qual se insere, apontando para suas ambiguidades, incertezas e tensões, o cinema perde sua efetiva dimensão de fonte história (MORETIN, 2007, p. 64).

Há uma atenção especial a isto nesta experiência, em que o filme se torna objeto de estudo para reflexão sobre o ensino de História, e como exercício de autoria discente. 


\section{Capítulo 4 ANÁLISE DOS FILMES}

Quando se discute uma questão de método na prática de análise de filmes, não está somente em jogo uma competência técnica particular, mas a mobilização de toda uma visão de cultura que, ao mesmo tempo estabelece o lugar do objeto no contexto social e o lugar da própria análise. (XAVIER, 1978, p. 12-13)

Para avaliar os filmes montados pelos alunos utilizei um caminho de racionalidade em que tanto a forma como o conteúdo mereceram considerações. Também busquei identificar a adesão do ensino de História a certa visão da historiografia, bem como a articulação entre elementos dos saberes escolar e extra-escolar.

Foram levadas em conta as características individuais dos filmes, organizadas em fichas de descrição dos trabalhos, e categorias gerais, construídas de forma a abranger elementos ou aspectos importantes das produções, que permitam identificar pontos de contato e de afastamento entre eles no que se refere à construção do tema, ao conteúdo histórico e ao uso da linguagem fílmica.

As fichas individuais foram elaboradas com o objetivo de se constituírem em fonte de consulta rápida quanto às características dos filmes. Elas constituem o anexo 1 desta dissertação e contêm os seguintes itens: classificação segundo nomenclatura proposta por Nova (1996), tempo de duração, técnica de animação, trilha sonora, gênero dos componentes do grupo que produziu o filme, legendas ou diálogos escritos e sinopse.

A classificação dos filmes segundo a nomenclatura proposta por Nova teve por objetivo incluir as obras dos alunos em um repertório de produções cinematográficas mais abrangente, caracterizando o formato pelo qual a linguagem utilizada na obra se aproxima da História. De acordo com os critérios estabelecidos pela autora, nenhum dos filmes pode ser considerado como documentário e sim filme ficcional, já que os alunos operam com diversas informações - das aulas, de livros, pesquisas - e as usam para criar uma leitura própria dos acontecimentos históricos. Das sete categorias criadas pela autora para filmes ficcionais, quatro foram suficientes para abranger todas as produções dos alunos: reconstrução histórica, biografia histórica, ficção histórica e filme-mito. Submeter os filmes a essas categorias pretende apenas localizar a produção dos alunos, em referência ao ofício do historiador.

As características dessas categorias, de acordo com Nova (1996), são:

Reconstrução histórica: corresponde aos filmes que abordam acontecimentos históricos cuja existência é comprovada pela historiografia e que contam com a presença de personagens históricos reais no seu enredo (...), cuja 
finalidade é relativa e se modifica de um filme para o outro. Não se trata apenas dos filmes em que se realiza uma reconstrução audiovisual do passado (o que dificilmente é levado às últimas consequências) ou mesmo dos fatos, mas também daqueles em que são esboçadas interpretações históricas, utilizando fatos comprovadamente reais. (...)

Biografia histórica: trata-se dos filmes que se debruçam sobre a vida de um indivíduo e as suas relações com os processos históricos. Na maior parte dos casos, esses filmes se limitam à abordagem da vida dos chamados "grandes homens", ou seja, aqueles indivíduos destacados pela historiografia escrita e, principalmente a tradicional. (...)

Ficção histórica: abarca os filmes cujo enredo é ficcional, mas que, ao mesmo tempo, possui um sentido histórico real.

Filme-mito: são aqueles filmes que se debruçam sobre a mitologia e que podem conter elementos importantes para a reflexão histórica. Muitas vezes o mito é apresentado em paralelo a fenômenos históricos reais (Nova, 1996, p. 98).

Na organização da técnica de animação descrevem-se e classificam-se elementos característicos da produção - como cenários e personagens - e também o processo utilizado para animar as cenas do filme.

Em trilha sonora são citadas as músicas presentes na produção, sejam elas instrumentais ou cantadas, utilizadas como parte integrante na sequência narrativa ou como fundo musical, identificadas pelo seu título e nomes dos compositores ou intérpretes, quando possível ou quando citados nos créditos do filme, ou ao menos pelo estilo de seu ritmo e de sua melodia.

As legendas ou diálogos escritos trazem transcrições de todos os textos, falas ou letras de músicas inteligíveis que integram o filme.

A sinopse, além de trazer uma descrição resumida da obra, contém algumas cenas do filme. Anexado a este trabalho encontra-se um CD com todas as produções na íntegra.

\subsection{Os critérios para a análise dos filmes}

A análise geral dos filmes produzidos pelos alunos explora especificamente seis aspectos - escolha do título, construção do enredo, construção das personagens, trilha sonora, elementos usados para conferir legitimidade ao filme e elementos de gênero -, os quais passo a comentar.

O título é o primeiro elemento dos filmes com o qual o público tem contato e pode oferecer informações importantes sobre o recorte que os autores criaram para o filme e a presença ou a manutenção de uma determinada memória sobre o ensino de História. Mas há escolhas que fogem aos conteúdos tradicionais. 
A continuidade analítica vem com a composição do enredo e os elementos mobilizados pelos alunos para sustentar a narrativa. Ele se constitui, para os grupos, em uma forma de utilização e apresentação do conteúdo trabalhado de tal modo que os alunos tenham verossimilhança e unidade narrativa, ainda que se afaste da versão oficial.

A composição das personagens - escolha de bonecos, sua caracterização também alude a determinada visão da História, com a presença do herói, ou a mobilização do humor para sustentar a crítica. Nesse sentido, juntamente com a análise da trilha sonora, compõe o eixo de análise sobre a forma específica de possibilidades discursivas que o cinema traz a esta atividade. Perceberemos que a linguagem fílmica implica em seleção dos elementos formativos e estes veiculam uma imagem que os alunos têm sobre a História e sobre o ensino da História. Porém noto também a possibilidade de abrirem um campo fértil no qual o saber extra-escolar se materializa na tela. Por vezes a sensibilidade de cada um dos grupos confere à obra produzida um contra-discurso.

A trilha sonora dos filmes, dentre outras características, pode confirmar, reforçar ou relativizar o discurso imagético da obra, incorporar outros sentidos ou sensações à narrativa, contribuir para sua contextualização histórica, comunicar-se com outros elementos relacionados ao tema trabalhado etc.

Outro elemento levantado nesta análise são os recursos utilizados pelos alunos para sustentar a legitimidade dos filmes. Nota-se que esses recursos participam da composição do enredo em maior ou menor grau, podendo constituir-se, por exemplo, de um trecho da carta-testamento escrita por Getúlio Vargas, ou um fragmento do noticiário da época, ou uma música, dentre outros.

Por fim, a análise segundo o gênero dos componentes do grupo teve por objetivo tentar justificar certas características presentes em determinadas produções, como, por exemplo, um grau exagerado de violência ou o uso de cor-de-rosa na composição das telas de fundo para exibição dos créditos do filme. Há uma constatação de que esta questão traz a dinâmica de montagem e produção de filmes a composição de formatos, resultando em produtos que talvez se possam denominar filmes de meninas ou de meninos, que, em comparação com os filmes produzidos por grupos mistos, apresentam diferenças latentes.

Em suma, a organização destes aspectos analíticos visa trazer maior objetividade ao estudo de um conjunto de fontes produzidas ao longo de dois anos de trabalho e que materializa uma aproximação do saber histórico que será avaliada no presente trabalho. 


\subsection{A construção dos títulos dos filmes}

Para facilitar a localização dos filmes que serão analisados, segue abaixo uma lista com a identificação e os títulos dos filmes 26 :

- Filme 1/2007: Uma outra visão da História: os cacos da Era Vargas;

- Filme 2/2007: A Era Vargas;

- Filme 3/2007: A Traição;

- Filme 4/2007: Getúlio Vargas: o fim!

- Filme 5/2007: Vargas e a disputa entre as lojas;

- Filme 6/2007: Era Vargas;

- Filme 7/2007: Já Era Vargas;

- Filme 1/2008: O vira-casaca;

- Filme 2/2008: O útimo 27 ato;

- Filme 3/2008: A Era Vargas (Wolf Productions);

- Filme 4/2008: A Era Vargas;

- Filme 5/2008: Um curta sobre a vida de Getúlio Vargas;

- Filme 6/2008: Era Vargas;

Uma primeira leitura desses títulos já nos aponta um caminho de indagação: quais critérios os alunos usaram para compor os nomes dos filmes? No conjunto das 13 obras, temos 7 delas com a citação direta da expressão Era Vargas. Outras 3 trazem a indicação pessoal do presidente, ou apenas Vargas. E os 3 grupos restantes criaram filmes em que o título faz referência a uma ação realizada pelo líder brasileiro. Nos filmes 3/2007, 1/2008 e 2/1008, os enredos giram em torno da figura do presidente Vargas, ainda que não se faça referência explícita à sua pessoa nos títulos.

O tema proposto para a construção dos filmes foi o governo de Getúlio Vargas no período entre em 1930 até 1954. Não foi feita nenhuma recomendação específica sobre a composição dos títulos, mas há uma preponderância do título usado na apostila: Era Vargas. No entanto, não é a simples repetição da expressão o elemento capaz de indicar que os alunos reproduziram o discurso sobre a escolha de uma personagem histórica.

Há outra configuração anunciada pela repetição da expressão Era Vargas: aquela que indica a própria visão da História à qual os alunos estão submetidos. Essa construção

26 Todos os filmes, na íntegra, estão inclusos no DVD anexo a este trabalho.

27 Mantive a redação original dos títulos, inclusive nos erros ortográficos. 
ocorre a partir da articulação do saber escolar formalizado nas aulas, do uso do material didático, juntamente com a narrativa da professora, e também das informações que trazem de um saber extra-escolar.

Em relação a isto, podemos identificar a chamada era Vargas como um achatamento da História, isto é, um período muito grande de tempo que passa a ser conhecido com um nome único, fazendo com que eventos de naturezas distintas sejam artificialmente aproximados, conferindo-lhes um sentido relacional que na verdade não possuem. O objetivo desta simplificação da História, ocultando-se conflitos e particularidades, seria o estabelecimento de uma percepção de ordem e coerência na história do país, a partir da lógica de interesse das classes dominantes.

Segundo a definição do conceito de História desenvolvida pelo francês Marc Bloch, "o objeto de estudo da História não é o passado. A noção segundo a qual o passado pode ser objeto de estudo é absurda. O objeto de estudo da História é o homem, ou melhor, os homens no tempo" (BLOCH, 2001, p. 52).

Ao assumir como um dos objetivos da História o estudo dos homens no tempo, há um indicativo de plural, ou seja, de uma busca por dar voz a outros grupos que não apenas o grande homem do passado ou a versão da classe dominante. Mas é essa a percepção de História que os alunos têm?

$\mathrm{Na}$ composição dos filmes realizados pelos alunos se verifica a presença de uma História marcada por heróis. Todos os filmes giram em torno dos feitos do presidente; há uma escolha narrativa do ponto de vista dessa personagem. Ao longo do texto do material didático estão presentes líderes executivos, mas poucos nomes são exaltados. No estudo sobre a chamada República Oligárquica, nem mesmo são citados os nomes de todos os presidentes do período.

No entanto, quando se trata de Getúlio Vargas, há dele diferentes representações. Ele é apresentado em fotos ou gravuras da Revolução de 1930, em encontros com outros chefes de Estado e em sua vida cotidiana, em caricaturas, em cartazes das celebrações do Primeiro de Maio, na ilustração de uma cartilha para crianças. Dessa forma, é fácil para os alunos a identificação visual do presidente.

A reiteração de uma História em que o líder atua como regente dos acontecimentos confirma uma visão positivista, ou seja, contrária a uma percepção na qual a complexidade dos fatos cria uma teia de possibilidades de ação, articulada por diferentes sujeitos. A versão que os alunos revelam sobre a História denuncia o quanto estão afastados 
de um processo autônomo de construção do conhecimento, a partir do momento em que recebem informações prontas, sem terem o direito de questionar sua origem ou intenção social.

Essa constatação não anula a proposição desta experiência didática. Está sendo proposto um exercício de pesquisa, de domínio de uma linguagem e da produção de um discurso autoral com veiculação da informação, mas isto não deve alterar significativamente a relação que possuem com o saber histórico, na posição de alunos. Percebo que a atividade não foi generalizante, ou seja, não se firmou como a modalidade mais adequada para aprender História, mas foi, com certeza na realidade das escolas A e B um outro caminho. O fato de os alunos reiterarem a escolha de uma história do heroísmo varguista revela a solidificação de um saber. Não caberia aqui perseguir o mito das origens e identificar o nascimento deste procedimento. Seria também um caminho fadado ao insucesso, pois são muitas as variáveis que apontam estas seleções. A análise dos filmes poderá apontar algumas possibilidades analíticas acerca da interação do saber escolar e extra-escolar dos alunos.

A tradição do ensino e da pesquisa em História fica sob a inércia da perpetuação do discurso dos vencedores, da classe dominante. Romper essa lógica não é fácil nem mesmo para o pesquisador, de modo que na posição de aprendizes, os alunos, na maioria das vezes, reiteram um mesmo conjunto de informações. No caso particular do tema utilizado pelos alunos para a produção de seus filmes o peso desta memória era inegável. Como vimos anteriormente, o governo de Getúlio Vargas funciona como um ponto em que se amarra o sentido da História para que esta tenha a coerência de um projeto de saber.

Sobre a Revolução de 1930, a memória dos vencedores é ainda mais solidificada, como afirma Vesentini (1997, p. 25-26):

Que o autor posicionava-se lá, fica bem claro. Que aquele dia representa uma existência outra, de eco ampliado, Revolução de 30, também. A pressão de um problema, qual um aríete, de amplas dimensões sociais, é visível. Apenas seu tratamento, pelo que o sugeriam, incomodava-os: estava marcado pela inadequação do método, e pela falsidade dos participantes. Assim o eu do autor chegou àquela manhã de 24 já bastante posicionado quanto ao problema, quanto à forma de encaminhá-lo, quanto aos personagens envolvidos. Mas com que força os episódios decorridos, para todos, conseguem pesar, tornam-se tão relevantes, e o próprio autor só percebe, "com maior amplitude de visão", em torno de 1940?

De modo geral, nos filmes, a personagem que merece caracterização específica com faixa verde e amarela é o presidente. O herói aqui, portanto, não é de Getúlio Vargas como individuo. Trata-se de uma complexa operação em que ele se torna, por representação, a encarnação do Estado brasileiro, é o presidente, a personificação do poder. As demais 
personagens são tomadas como massa, ou seja, sem identidade; são rostos enfileirados, como no filme 3/2007, ou classificados como trabalhadores, a partir dos seus ofícios, como no filme 6/2007, com cores diferentes daquelas dos bonecos, como utilizado nas obras 3/2008 e 6/2008, ou com uma fotografia de multidão, em 4/2008.

Sobre essa concepção da população como uma massa amorfa e a utilização dos meios de comunicação para veiculação do discurso oficial dirigido a ela, no período Vargas, escreve Lacerda:

No período estadonovista esse discurso [veiculado pelo rádio] passa a ser conjugado a outros, de natureza distinta, como os discursos visuais (cinema, fotografia etc.), produzindo um sentido novo na mensagem veiculada. $\mathrm{O}$ emprego desses novos meios de comunicação de massa pelo governo vem ao encontro da própria concepção de massa dos ideólogos do regime, qual seja, a de unidade amorfa, incapaz de racionalização, e consequentemente vulnerável a ser conduzida por outros apelos como a emoção, a intuição etc. Daí o destaque atribuído às imagens na construção das representações míticas em torno do chefe do governo e do próprio regime (LACERDA, 1994, p. 245).

O filme 7/2007 faz uma crítica a essa exaltação do líder. O formato utilizado pelo grupo para compor a oposição a uma visão heróica do presidente é a própria referência canônica à Era Vargas, mas com uma variação: Já Era Vargas! - Aliás esse é o tom dado a todo o filme: o de ser o contrário da versão oficial da História. Mas esse avesso parte de referências tradicionais, tais como o nome do período e o título utilizados no material didático, o apoio na carta-testamento para uma interpretação da História - mesmo que o enredo faça a revelação de que foi encontrada outra carta-testamento - e a conclusão, com o suicídio, de modo que há uma linearidade narrativa que aproxima a versão oficial e aquela proposta pelo grupo.

Nota-se, com o trocadilho feito no título do filme, utilizado enquanto recurso linguístico de narrativa, uma sofisticação de pensamento do grupo. A escolha pelo contradiscurso pressupõe um entendimento mínimo por parte do espectador, que deveria conhecer a carta-testamento oficial, para dar-se conta de sua nova interpretação, calcada nas brechas. Ou seja, é como se fossem de tal modo improváveis as declarações contidas no documento que se pudesse inverter seu sentido sem maiores implicações.

A aceitação de um contradiscurso se torna possível, na narrativa fílmica, pelo estabelecimento de um acordo ficcional, como nos explica Eco:

A norma básica para se lidar com uma obra de ficção é a seguinte: o leitor precisa aceitar tacitamente um acordo ficcional, que Coleridge chamou de "suspensão da descrença". O leitor tem de saber que o que está sendo narrado é uma história imaginária, mas nem por isso deve pensar que o escritor está contando mentiras. De acordo com John Searle, o autor 
simplesmente finge dizer a verdade. Aceitamos o acordo ficcional e fingimos que o que é narrado de fato aconteceu (ECO, 2006, p. 81).

Aqui o tratamento dado ao conteúdo do filme se intensifica a partir da montagem realizada pelo grupo. Talvez a noção precisa de sua função não seja de todo apreendida pelos alunos, no entanto há certa alfabetização, ainda que intuitiva, uma vez que também eles são espectadores de cinema e percebem a função irrestrita da montagem. Ela não é apenas um método para juntar cenas, mas um recurso potente que controla a direção psicológica do espectador.

Deve-se aprender a entender que a montagem significa, de fato, a direção deliberada e compulsória dos pensamentos e associações do espectador. Se a montagem for uma mera combinação descontrolada das várias partes, o espectador não entenderá (apreenderá) nada; ao passo que se ela for coordenada de acordo com o fluxo de eventos definitivamente selecionados, ou com uma linha conceitual, seja ele movimentado ou tranquilo, a montagem conseguirá excitar ou tranquilizar o espectador (PUDOVKIN, 2003, p. 62).

Assim, no filme 7/2007, com a estratégia de montagem onde o presidente lê um novo texto para a carta-testamento e simultaneamente há a veiculação de outras imagens, confirma-se a legitimidade do novo discurso, através do recurso da reiteração do tema, como definido por Pudovkin:

Leitmotiv (reiteração do tema). - Em geral, interessa ao roteirista dar ênfase em especial ao tema básico de um roteiro. Para tal propósito, existe o método da reiteração. Sua natureza pode facilmente ser demonstrada com um exemplo. Num roteiro anti-religioso visando expor a crueldade e a hipocrisia da Igreja a serviço do regime tzarista, o mesmo plano foi repetido várias vezes: um sino toca vagarosamente, com os seguintes letreiros superpostos: "O som dos sinos envia ao mundo uma mensagem de paciência e de amor". Este plano apareceu todas as vezes em que o roteirista desejava enfatizar a estupidez da paciência, ou a hipocrisia do tal amor pregado (PUDOVKIN, 2003, p. 65).

A proposição de um enredo em que a versão oficial da História é contestada foi bem amarrada pelo grupo, pois sua nova argumentação se apóia no uso de outro documento fictício e na estratégia de uma montagem com a reiteração do tema. Outrossim, o filme constrói uma argumentação hermética capaz de oferecer ao espectador a verossimilhança e a aceitação.

Essa formatação pode ser ainda mais reveladora quando vemos no filme uma narração histórica que desconfia das verdadeiras intenções do presidente, presentes na cartatestamento, texto que está presente no material didático que usam em aula. Para que a verdade venha à tona é necessário descobrir outro vestígio e, a partir dele, reescrever a História. Decerto, o grupo não percebeu que é possível ler a mesma fonte de maneiras distintas, sem apenas reproduzir as informações explícitas que ela encerra. $O$ grupo segue um 
encaminhamento positivista do ofício do historiador, isto é, o ideal de uma história total - em que a fonte somente pode apresentar uma possibilidade de interpretação, de maneira que para alterar a versão oficial dos fatos é necessária a descoberta de uma nova fonte (que contradiga a primeira)?

Como justificativa possível para a adoção desta postura por parte do grupo, podemos considerar a influência de materiais que a mídia veicula, como documentários que anunciam novas descobertas arqueológicas, novos documentos etc., transmitindo-nos a ideia de que só se entenderá melhor a História se forem descobertos novos documentos, ou seja, como se o documento, por si só, fosse a única maneira para descrever o passado.

Isso é certamente tributário da ideal de uma história total, que era dos positivistas, mas continua muito presente entre os historiadores menos avisados e, certamente, na relação que a maior parte do público não especializado mantém com a história: "um dia, quando novos documentos forem revelados, saberemos a verdade".

Em termos metodológicos, constata-se que os alunos da Escola B nunca haviam feito exercícios de análise de textos que escapassem aos níveis superficiais de leitura. Liam apenas o explícito. Na escola, para eles, a obra não estava aberta. A escolha por um título no qual a referência ao tema ficasse explícita se configurava como a opção mais segura para os grupos.

O título do filme 5/2008 - Um curta sobre a vida de Getúlio Vargas - anuncia a relatividade da versão que o grupo apresenta, ou seja, não é $o$ filme sobre a vida do presidente, mas apenas um, permitindo a existência de mais de uma possibilidade de encaminhamento para a História. Não há preocupação em dar conta de um conjunto de informações sobre o líder brasileiro, mas de uma seleção deliberada, talvez uma percepção do ofício do historiador, o qual opera com escolha de fontes e informações, para criar um conjunto que faça sentido.

A repetição do nome do presidente ou da expressão Era Vargas pode indicar, além de um ensino de História calcado na construção de heróis e versões simplistas do passado, certo medo de ousar. Embora a proposta da elaboração dos filmes tenha sido livre, é certo que os alunos que aderiram a ela percebiam uma estreita relação com o formato de saber escolar. Ou seja, tratava-se de um projeto temático, que seria alvo de nossos estudos em sala de aula, que se tornariam conteúdos sobre os quais se fariam provas. Somam-se a esse fato as especificidades do controle disciplinar característico das escolas em que os trabalhos foram realizados, descrito no capítulo 1. 
Vesentini (1984) chama a atenção para o fato de existirem, ao longo da organização das exposições historiográficas, certos temas fulcrais, aos quais se referencia todo encaminhamento de construção de sentido. Um desses nós específicos da história do Brasil é a Revolução de 1930, ou como consta no material didático utilizado na sala de aula, o início da Era Vargas. Vesentini mostra como os historiadores caem nessas armadilhas, até mesmo no momento em que buscam a crítica. De que modo os alunos que fizeram os filmes poderiam ter escapado disso? Um exercício de produção autoral pode ser um caminho?

$\mathrm{Na}$ organização deste projeto não era apenas pelo tema ou formato que se pretendia oferecer outras possibilidades de acesso ao conhecimento histórico. Havia uma singularidade, na qual a aposta era maior: o uso da linguagem cinematográfica. Talvez a operação com uma modalidade narrativa privilegiada pela construção da imagem, do sentido da narrativa, e dotada de uma veiculação a outros sujeitos puderam criar alguma alteração no discurso.

Para verificar essas possibilidades, segue-se a análise da composição de enredo, das opções de informações canônicas ou não que foram mobilizadas para a construção das imagens veiculadas no filme.

\subsection{O enredo: opção de conteúdo e articulação com a forma}

A temática abordada nos filmes privilegiou um recorte de conteúdos em que a História do Brasil fosse o alvo. Algumas obras mantiveram-se exclusivamente neste ângulo, e dedicaram-se à narração ou à compreensão de fatos de um período histórico apenas a partir de informações da história nacional, como se pode verificar nos filmes 1/2007, 2/2007, 7/2007, 4/2008 e 5/2008. Em todos os demais, percebe-se ao longo do desenvolvimento dos enredos uma aproximação em direção às informações da História Geral para justificar os arranjos do governo Vargas. Trata-se de uma quantidade significativa: são 8 filmes a operar com este último tratamento e apenas 5 dedicando-se ao primeiro, para o desencadeamento da narrativa.

Através desta constatação podemos tecer algumas considerações a respeito da relação que os alunos estabelecem com a organização do currículo sob o modelo de História integrada, em que são sequenciadas as informações factuais ora do Brasil, ora da Europa e ora da América, estabelecendo uma espécie de lógica em que os espaços são intercalados e não integrados - esta é uma questão que o currículo escolar de História não enfrentou até hoje, porque, mesmo tendo sua origem na necessidade de afirmação dos Estados nacionais, esta foi 
cindida pelo nosso estado anterior de colônia; isto fez com que se iniciasse, a partir do século XIX, um esforço para inventar o Brasil, e a proposta de divisão do currículo entre História do Brasil e Geral é fruto disto.

Há uma particularidade no filme 1/2007 - Os Cacos da Era Vargas: o conteúdo específico do período de 1930 até 1954 não é abordado de modo explícito, ou seja, a referência não são os fatos canônicos do governo, mas seus efeitos. Trata-se de uma obra em que há uma percepção da longa duração do modo de governar o país, herdado de Getúlio Vargas. Estas ações são personificadas em um vaso - os alunos operam com os efeitos aludidos de seu mandato, e não de sua figura.

Nesta metáfora, portanto, a História é um vaso, do qual não podemos nos livrar; ela deixa um efeito na sociedade. Livrar-se dela pode causar um efeito distinto daquele esperado: vazos ruins não quebram... a menos que te quebrem junto! - Seria aqui a História uma força que determina o futuro do país, ou o lugar privilegiado onde podemos encontrar um caminho provável para seguir? Nesse filme, Vargas não é uma personagem; é um continuum. Há inclusive uma palavra de ordem para escapar da força controladora da História: Brasil, chega de recolher cacos... A redenção da sociedade diante do fluxo opressor da História é vivê-la plenamente, não aceitar apenas os cacos, talvez as partes desconectadas que conhecem na escola. Está no próprio passado a dimensão de superação.

Outra possibilidade de interpretação para o vaso é a de que ele simbolize a própria era Vargas, como conteúdo do ensino de História apresentado aos alunos; neste caso, os cacos - que é o que efetivamente sobra para eles - representariam uma ruptura ou fragmentação desse conteúdo, impossibilitando aos alunos a percepção de uma identidade, ou seja, a elaboração de um conhecimento significativo sobre o tema.

Os alunos construíram um sentido paradoxal para a História, em que determinação e libertação fazem parte da mesma característica deste saber. Ela deve ser operada, estudada, com o objetivo de emancipação, caso contrário o preço é um sofrimento anunciado. Existe um convite contundente para o estudo da História: é hora de parar de apanhar calado! De onde vem essa percepção? Trata-se da velha crença iluminista de uma emancipação que chega por meio do conhecimento, de um discurso que justificaria a escolarização e a submissão às regras e formas escolares?

Miceli advoga que,

(...) de acordo com o historiador francês [Jacques Le Goff], o Brasil integra o grupo dos "países oprimidos que lutam pela sua história como pela sua vida", o que não quer sugerir que a legitimação do historiador dependa da transformação de seus instrumentos de trabalho em armas de combate, ou de 
sua passagem dos arquivos e bibliotecas para as trincheiras e campos de cultivo coletivos. Também não se propõe que os historiadores devam pôr-se como guias de todos os oprimidos na luta pela emancipação (MICELI, 2006, p. 38).

No filme 3/2007, até mesmo o espaço físico do palco é dividido entre o líder brasileiro e Adolf Hitler. Nesse caso, a internacionalização é de tal modo explorada que o líder nazista vem à cena com um chapéu nas cores e no formato da bandeira norte-americana, mas que possui no topo a suástica nazista. Essa sobreposição de signos gera uma gama de possibilidades interpretativas: o uso do chapéu norte-americano por Hitler indica elementos comuns tanto no governo americano quanto no alemão? Ou trata-se de um encaminhamento de análise em que os tiranos não têm nacionalidade? Ou ainda que todos os líderes desejam explorar o Brasil? Não é certo que os alunos que montaram o filme tivessem clareza de todo esse simbolismo, mas é este o potencial da produção cinematográfica como uma modalidade de narrativa: há significados que escapam até mesmo do diretor.

No filme 4/2007 todo o enredo é construído com base na participação do Brasil na Segunda Guerra Mundial. O desfecho do filme, com a destruição provocada pelo conflito chegando ao presidente e sufocando-o parece remeter à explicação simplista presente no material didático usado nas escolas: Getúlio renuncia porque a democracia havia vencido no mundo e não havia mais espaço para ditaduras; o modelo de governabilidade do Estado Novo chegou ao fim, não havendo espaço para Vargas após o término da guerra.

Dois filmes - 3/2008 e 6/2008 - abordam a participação do Brasil na Segunda Guerra Mundial, relacionando-a ao suicídio do presidente Vargas. Esta seria uma maneira de estabelecer um ponto de contato entre os conteúdos da História Geral e do Brasil. O filme 3/2008 trata a morte do presidente tal como a de um herói romântico que morre ao final, mas não o faz em vão; apenas foi incompreendido por sua atitude heróica de levar o país a participar da Guerra.

Nota-se nestes dois filmes, como já citado anteriormente, um efeito de achatamento da História. Dois eventos - suicídio de Vargas, ocorrido em 1954, e participação do Brasil no conflito terminado anos antes - são aproximados, forjando-se uma relação entre eles.

Pode-se ainda considerar essa relação entre um evento da história nacional e um fato internacional como um recurso para se tentar agregar ao discurso maior amplitude e legitimidade. Há uma espécie de internacionalização dos temas de História do Brasil, estabelecendo-se ligações entre as ações do presidente brasileiro e a lógica externa, nos filmes 6/2007, 1/2008 e 6/2008, que exploram a ideia da influência do imperialismo norte-americano 
sobre o Brasil. No primeiro desses filmes evidencia-se um sentido de espoliação: o presidente americano quer comprar a Petrobrás, mas Vargas não aceita, reforçando a imagem de um líder protecionista, que ao mesmo tempo enfrenta um inimigo estrangeiro e manipula o povo em um comício, que conta até mesmo com cobertura jornalística - nessa sequência, o presidente joga bolacha recheada para a massa de trabalhadores, em uma metáfora do líder populista.

Assim, a estetização da política ligou-se a esses espetáculos cívico-artísticos almejando despertar no homem brasileiro o espírito da renúncia às coisas materiais, mediante a exaltação do trabalho, da fé, da disciplina e do amor pelo Brasil.

Os ideólogos do Estado Novo ou do Brasil Novo perceberam claramente a importância dos meios modernos de comunicação (rádio, jornal, disco) e de algumas artes (música) como recursos capazes de politizar rapidamente as massas populares" (CUNHA, s/d, p. 20).

A obra opera com uma memória da política nacional em que o líder ideal funciona como um defensor dos interesses nacionais, ainda que a população seja preterida ou explorada. Os alunos autores dos filmes, em particular, fazem parte da classe média e talvez esta possa ser uma razão para não se importarem com o descaso do presidente frente à massa de trabalhadores. Ou estaria inserido aí um tom de denúncia do populismo, como farsa, isto é uma crítica à atitude do presidente.

O filme mostra, ainda - pela recusa de Vargas em vender a Petrobras aos americanos - uma intenção de proteger o patrimônio nacional. Pode-se imaginar que essa imagem do presidente como o grande líder nacionalista está presente no saber escolar e extraescolar - com particular destaque à memória de seus familiares e à mídia -, como o resultado de um esforço na produção da memória das classes dominantes.

A relação do aluno com estes diversos elementos da cultura lhe oferece uma pluralidade de narrativas, o que é importante na sua constituição como sujeito dotado de uma produção autônoma do conhecimento, a qual é sempre relacional, como afirma, a esse respeito, Bittencourt:

As novas interpretações sobre a aprendizagem conceitual e a importância das interferências sociais e culturais nesse processo erigiram o aluno ou o aprendiz e seu conhecimento prévio como condição necessária para a construção de novos significados e esquemas. Como consequência, a psicologia social passou a contribuir para a reflexão acerca das consequências de aprendizagens, partindo do conhecimento prévio dos alunos.

No que se refere ao conhecimento histórico, essa posição torna-se ainda mais relevante, levando em conta as experiências históricas apresentadas pela mídia - cinema e televisão, em particular - por parte das crianças e dos jovens, em seu cotidiano. A História escolar não pode ignorar os conceitos espontâneos por intermédio de tais experiências (BITTENCOURT, 2005, p. 189). 
Existem dois filmes - 3/2007 e 1/2008 - que abordam de modo mais significativo as relações do Brasil com Estados Unidos e Alemanha. Como pontos de aproximação entre eles, podemos notar, por exemplo: ambos estabelecem inicialmente uma relação entre Vargas e Hitler - no filme 3/2007 são exibidas, em sequência, duas cenas, mostrando a capacidade de comunicação dos líderes com a massa e no 1/2008, o presidente recebe uma chamada telefônica do líder alemão.

Ambos também estabelecem, em um determinado momento, uma mudança de opção do presidente para o lado americano, atribuindo a esta atitude um sentido negativo, o que se pode perceber através de seus títulos - A Traição e O Vira-casaca. No entanto, o efeito dessa ação é distinto em casa uma das produções: no primeiro há um posicionamento radical de Vargas, enquanto no segundo há uma dissimulação de adesão, ou seja, o líder brasileiro aparentemente concorda com a exigência norte-americana de abandonar os princípios nazistas, porém fica com os dois - o capital estadunidense e a prática de princípios autoritários. Talvez a aproximação econômica dos Estados Unidos ativa a noção de que o capital não tem pátria, e pode ser combinado com o nazismo.

Outro tratamento semelhante é o dado à representação dos Estados Unidos como representante do capital econômico - no filme 1/2008 isto se dá por meio da caracterização do país norte-americano como Ronald Mcdonalds e no 3/2007, como uma latinha de Coca-cola, ambos ícones do consumo.

O filme 2/2008 utiliza um elemento simbólico para representar uma aproximação entre Vargas e Hitler, a partir da colagem do bigode do líder alemão no presidente brasileiro. Novamente, de alguma forma, o encontro entre temas nacionais e internacionais é estabelecido.

A montagem do enredo não é mera expressão de um roteiro. É antes o resultado de uma importante articulação com a forma fílmica; a escolha dos elementos usados para tornar o filme realidade é significativa e também portadora de uma mensagem. Nesse sentido, quais são as personagens usadas pelos grupos para apresentar essas relações internacionais? Como são caracterizados o presidente norte-americano e o líder nazista? E o presidente brasileiro?

No filme 6/2007 o presidente americano é um boneco de cabelos longos, com óculos escuros, terno branco e uma faixa onde se lê USA. Vargas, por sua vez, usa terno cinza, bem mais sóbrio, tem cabelo curto, barba e usa óculos de leitura. A construção de uma imagem presidencial para Getúlio parece remeter novamente ao presidente ideal, em comparação ao estilo pop do norte-americano. Os óculos escuros podem trazer a mensagem 
de dissimulação, daquilo que não deve ser revelado, até mesmo a inscrição na faixa está em inglês - USA.

O presidente brasileiro, com sua apresentação mais sóbria, nas roupas de cor cinza, sem nenhuma identificação aparente de sua posição política, é localizado a partir de suas ações: está na primeira cena liderando o comício, interage com o presidente norteamericano e suicida-se ao final.

No filme 3/2007 as personagens que representam o presidente brasileiro e Adolf Hitler foram fabricadas pelo grupo, a partir das ilustrações de seus rostos adaptadas a corpos articulados. O rosto do brasileiro, no entanto, foi desenhado por um dos componentes do grupo e não possui muita semelhança com as imagens canônicas de Vargas, enquanto o do líder alemão é uma reprodução baseada numa determinada fotografia de Hitler, capaz de gerar uma determinada representação sobre o alemão. Nas cenas, este usa um chapéu feito com as cores e o formato da bandeira dos Estados Unidos, porém exibindo em seu topo uma suástica.

A ironia evocada pelo desfile das personagens em um palco reforça a ideia de dissimulação da política, tema recorrente no discurso da mídia e talvez dos pais dos alunos, enquanto pertencentes à classe média. A reiteração dessa imagem da política nacional é confirmada pela passividade da massa de espectadores, que estão diante do palco. Eles não têm identidade, são rostos na multidão; os mais próximos dos líderes estão com uniformes nazistas ou integralistas, identificados através dos símbolos da suástica e do sigma. Mais ao fundo, a multidão fica cinza.

Neste sentido, a percepção de alienação da massa diante da política também é internacional, a subserviência passa a ser um efeito generalizado, revelando um descrédito na ação política como um todo, tornando universal uma acusação comum do saber extra-escolar que insiste na incapacidade de mobilização do povo, representação comum na época, presente, por exemplo, na personagem do Jeca Tatu, de Monteiro Lobato. Expandir as fronteiras da alienação popular diante da manipulação dos líderes também pode inocentar o Brasil; é identificar no cenário interno uma projeção do externo, assim como aproximar-se da repetição de imagens.

Há uma indicação pertinente da relação estabelecida entre o Estado e as massas, notada em um discurso extra-escolar, mas também marcada por uma narrativa histórica, em que a violência e o controle da oposição ganham espaço com a violência do período, até a organização do Estado Novo, quando a relação entre o poder estatal e o cidadão se altera profundamente, conforme afirma Fausto: 
Mas o reajuste, obtido após um doloroso processo de gestação - marcado pela Revolução de 1932, a Ação Integralista, a liquidação do tenentismo como movimento autônomo, a Aliança Nacional Libertadora e a tentativa insurrecional de 1935 -, significa uma guinada importante no processo histórico brasileiro. A mudança das relações entre o poder estatal e a classe operária é a condição do populismo; a perda do comando político pelo centro dominante, associada à nova forma de Estado, possibilita, a longo prazo, o desenvolvimento industrial, no marco do compromisso; as Forças Armadas tornam-se um fator decisivo como sustentáculo de um Estado que ganha maior autonomia em relação ao conjunto da sociedade. (FAUSTO, 2000, p. 151)

A presença da guerra nos enredos dos filmes merece atenção em um duplo sentido: em primeiro lugar, por ser um elo entre os fatos nacionais e os internacionais, e em segundo lugar, por ser um tema recorrente, citado em três filmes - 4/2007, 3/2008 e 6/2008.

O que leva os grupos a fazerem a opção por esse tema? No material didático usado nas aulas não há referência ao número de mortos na Segunda Guerra Mundial, assim como não há imagens que corroboram a própria realidade dos combates. No caso específico da participação do Brasil nos confrontos, há somente a citação da criação da Força Expedicionária Brasileira e da Força Aérea Brasileira. A escolha pelo tema seria uma reação a essa superficialidade com que o conflito é tratado. Esta percepção se torna ainda mais significativa quanto contraposta a um discurso da mídia em relação à Segunda Guerra Mundial, que reforça exatamente o caráter mortífero do conflito - um exemplo a ser considerado é o filme Gen Pés Descalços, que narra os efeitos da explosão da bomba de Hiroshima. Assim, os alunos encontram versões diferentes sobre a Guerra: no livro didático ela existiu mas não há citação dos seus efeitos destrutivos para as pessoas envolvidas, enquanto a mídia denuncia exatamente esse caráter de hecatombe.

No filme 3/2008, o grupo utiliza cenas de documentários do período da formação das tropas brasileiras que foram lutar na Europa para dar um sentido de ufanismo e também de amadurecimento do país, pois este se envolverá em um momento importante da História mundial. Esta mensagem é reforçada pela narração dos documentários selecionados para a montagem. No entanto, o discurso encontra uma contrapartida na sequência de cenas da batalha: em um campo de guerra fabricado, exércitos de bonecos de plástico coloridos se enfrentam até a vitória dos aliados. A escolha de bonecos que variam apenas nas cores reforça a mensagem de massa de soldados, sem identidade, e cria uma percepção de manipulação das personagens. Será que o heroísmo anunciado nas cenas do documentário combina com a ação dos soldados na batalha?

Nas sequências das batalhas de bonecos a dramaticidade é garantida por uma sonoplastia de alta qualidade - com disparos de armas, silvos de balas e demais ruídos de 
guerra -, combinada com o dinamismo das tomadas de câmera. Houve uma opção pela montagem da simultaneidade, em todo o filme, entre a encenação da História nacional e o realismo das imagens documentais sobre o tema. No entanto, a duplicidade do formato documentário-encenação deixa escapar elementos de interpretação. Novamente temos uma modalidade de ensino de História anunciado: aquele que usa o documento como expressão direta da realidade histórica, dispensando qualquer ação analítica.

A contribuição da linguagem fílmica reforça o sentido de unidade discursiva e a manutenção de um modo de interpretação histórica baseado na prova - tal como os alunos se acostumam por meio das práticas da avaliação escolar. Ou seja, a reconstrução histórica se baseia na leitura de informações, pois estas já estão dadas pelos monumentos produzidos no passado, mesmo que estes estejam nitidamente vinculados ao grupo social que os produziu. Neste caso, a informação se sustenta com a inscrição, nos vídeos, da sigla do Departamento de Imprensa e Propaganda (DIP).

Outro tema privilegiado na construção do enredo é aquele do desenlace físico da personagem na trama histórica do percurso de Getúlio Vargas como político brasileiro: a sua morte. Ele é verificado em 8 dos 13 filmes produzidos pelos alunos - 4/2007, 6/2007, 7/2007, 2/2008, 3/2008, 4/2008, 5/2008 e 6/2008, sendo que neste último caso, o suicídio é apenas anunciado, posto que na cena final Vargas senta-se e escreve a carta-testamento.

$\mathrm{O}$ ato do suicídio, por sua dramaticidade, parece combinar com a linguagem do cinema, fornecendo às tramas uma pluralidade de usos e interpretações, por exemplo sendo usado como punição, ato heróico ou fuga. No entanto, o fato em si não encerra a questão da Era Vargas, uma vez que este conceito se prolonga, perpetuando sua memória junto a outros políticos, influindo na forma de condução da administração pública.

A canonicidade do tema do suicídio é reforçada pela organização do material escolar usado pelos alunos, em que há a uma reprodução da carta-testamento impressa e em folha diagramada tal como um pergaminho, conferindo-lhe solenidade. No entanto, vale uma conferência: será que todos os filmes tratam a morte do presidente da mesma maneira, confirmando o teor explicativo do documento?

Nos filmes 6/2007, 7/2007, 2/2008, 3/2008 e 4/2008 há sequências sobre o suicídio de Vargas. Mas as abordagens não são as mesmas. No filme 6/2007, o suicídio está na cena, mas não há uma sequência lógica de sua morte. $\mathrm{O}$ enredo se ocupa em mostrar as boas obras do presidente: controla o povo com medidas populistas, nega a privatização da Petrobrás aos norte-americanos e por fim, o suicídio. Seria esta uma tentativa de justificar que o herói não morreu em vão, uma referência ao suposto heroísmo do presidente? 
No filme 7/2007 o sentido dado ao suicídio é outro. Trata-se de uma fuga do líder brasileiro, que anuncia suas reais intenções, apoiadas em uma nova carta-testamento, encontrada posteriormente. Ao mesmo tempo foi uma punição imposta por Hitler, que leva o presidente brasileiro ao mesmo local em que ele está - o inferno. Nesse sentido, ambos os líderes se encontram em semelhante grau de responsabilidade histórica - o de um tirano. Aqui a morte assume a conotação de justiça, funciona como um alívio para o espectador que assiste Vargas ser castigado, diante dos abusos cometidos por seu governo. Afinal, ele vai para o inferno, referência de punição no universo cristão, e encontra Hitler, que quer se vingar do brasileiro que o abandonara.

Diante de uma mesma informação histórica os alunos realizam leituras diferentes, e a utilização desse episódio para a construção do enredo foi fundamental para essa constatação, diante da variabilidade de discursos apresentados. Sendo o suicídio do presidente uma imagem canônica, observamos que

Todos nós lidamos, a todo momento, com imagens canônicas. Os livros didáticos são quase que infinitamente ilustrados com imagens canônicas. (...) elas sempre exigiram, de forma inconsciente, uma atitude mais de fé e de crença, do que qualquer outra coisa mais racional. $\mathrm{O}$ choque ante uma imagem não-estereotipada pode ser revelador: às vezes, de imediato, começamos a perceber como a imagem com a qual nos acostumamos - a imagem canônica - é coercitiva. Coercitiva porque nos impunha uma figura reproduzida infinitamente em série, tão infinitamente repetitiva que não mais nos provocava nenhuma estranheza, bloqueava nossa possibilidade de uma representação alternativa, ou seja, não nos levava mais a distinguir, a comparar - em suma, não nos levaria mais a pensar (SALIBA, 2007, p. 88).

Nos filmes 2/2008 e 4/2008, a temática do suicídio ocupa todo o enredo. Em ambos os casos, o tema é esticado, conferindo ênfase aos momentos finais do presidente e aos fatos que desencadearam o desfecho de sua morte. Outro ponto comum é o atentado da rua Toneleiros, ou seja, o atentado ao jornalista de oposição Carlos Lacerda, do qual Vargas é indicado como o mandante. $\mathrm{O}$ fato de ambos os filmes apresentarem em sua primeira cena $\mathrm{o}$ mesmo episódio sustenta uma evidente simplificação da História nacional, em que a culpa por um crime é solucionada com o suicídio.

Ocorre a reiteração do tema e da linearidade explicativa apresentada no texto do material didático, naquilo que se refere ao enredo. É na construção do filme que outros elementos são anunciados. No filme 2/2008 a narrativa é tão breve que traz a sensação de que o espectador perdeu alguma informação. A sequência truncada (o planejamento e o atentado a Carlos Lacerda e a inscrição E Vargas se mata!, seguida da cena que a confirma) cria dúvida em relação à ligação imediata e única entre o atentado da rua Toneleiros e o suicídio do presidente, simplesmente por ser Getúlio indicado como mandante do crime. Essa justificativa 
parece ser, de fato, o argumento do enredo, mas da forma como foi apresentada, rápida e truncada, torna o recurso frágil.

O fato de o filme ser curto pode não indicar desinteresse do grupo em sua preparação, ou mesmo um despreparo técnico, uma vez que se pode notar um trabalho elaborado na montagem da trilha sonora, que contém, em uma sequência breve, 4 trechos de músicas diferentes; esta realidade não está presente em nenhum outro filme.

Outra interpretação possível, ainda com respeito a esse filme, é a de que mesmo esta versão sendo anunciada no material didático, assim como a redação da carta-testamento, ela parece não ter sido considerada pelo grupo no seu sentido positivista, ou seja, como a verdade que sobreviveu. Este filme permite ao leitor um convite, solicita que o espectador complete a sequência com o objetivo de lhe conferir sentido, e é aqui que a História narrada pode ser posta em xeque. É como se a obra questionasse: faz sentido Vargas se matar por ter tramado um atentado contra um jornalista de oposição? É certo que Calos Lacerda não era simplesmente um jornalista de oposição; era com certeza o maior e o mais evidente líder da oposição a Vargas, ao getulismo e ao trabalhismo de modo amplo. Não é no enredo, pura e simplesmente, que está a contribuição do filme, mas no uso que ele faz da linguagem. Aliás, é essa uma das características mais caras de um texto:

Por enquanto, só quero dizer que qualquer narrativa de ficção é necessária e fatalmente rápida porque, ao construir um mundo que inclui uma multiplicidade de acontecimentos e de personagens, não pode dizer tudo sobre esse mundo. Alude a ele e pede ao leitor que preencha toda uma série de lacunas. Afinal (como já escrevi), todo o texto é uma máquina preguiçosa pedindo ao leitor que faça uma parte de seu trabalho (ECO, 2006, p. 9).

Já no filme 4/2008, há uma profícua adesão à versão do suicídio como solução para um impasse em que o presidente é acusado de ser o mandante de um atentado à vida de Lacerda. Embora a obra conte com uma sofisticação de detalhes, tais como a fachada e o interior do palácio do Catete, e um esmiuçar dos eventos pertinentes ao desfecho do caso, a confirmação de uma versão da História revela a força da memória do ensino, que parece simplificar a ação dos sujeitos. No entanto, a caracterização do presidente como um cavaleiro medieval remete a um simbolismo de herói, fato que pode deixar em aberto a versão canônica de relação imediata entre o atentado e o suicídio. Este fato confere à obra um sentido maior de complexidade.

O tratamento dado ao enredo indicia uma aproximação muito particular dos alunos que produziram os filmes à História. Todos os trabalhos possuem caráter ficcional eles não têm a pretensão de ser a verdade histórica, mas sim um exercício de leitura e interpretação sobre um tema específico estudado em aula. 
Cada um dos filmes é uma experiência em que se considera que

O objetivo primeiro do conhecimento histórico é a compreensão dos processos e dos sujeitos históricos, o desvendamento das relações que se estabelecem entre os grupos humanos em diferentes tempos e espaços. (BEZERRA, 2005 p. 42)

Nem sempre os alunos escapam de uma memória histórica já estabelecida, na qual os heróis são exaltados e confirmados na modalidade específica do saber escolar. No entanto, a análise dos enredos mostra que a operacionalização que fazem das informações veiculadas pelo material didático, pela fala da professora e também de um saber extra-escolar, é dinamizada a partir da linguagem cinematográfica. Esta torna a construção de uma mensagem em outra, ou seja, confere uma nova dimensão à significação, a qual muitas vezes escapa do controle consciente dos alunos que montaram os filmes, e abre um importante caminho analítico.

Qual foi a relação que os filmes estabeleceram com a memória do governo de Getúlio Vargas? Penso que cada filme traz uma resposta muito específica a esta questão, mas há obras em que é possível verificar um esforço de entendimento do grupo em relação ao tema escolhido. Até mesmo a reiteração pode encontrar na linguagem a criação da obra aberta, em que a História se torna uma modalidade de conhecimento a ser explorado e não apenas anunciado em uma sucessão de informações.

Ciente de que o conhecimento é provisório, o aluno terá condições de exercitar nos procedimentos próprios da História: problematização das questões propostas, delimitação do objeto, exame do estado da questão, busca de informações, levantamento adequado das fontes, percepção dos sujeitos históricos envolvidos (indivíduos, grupos sociais), estratégias de verificação e comprovação de hipóteses, organização dos dados coletados, refinamento dos conceitos (historicidade), proposta de explicação para os fenômenos estudados, elaboração de exposição, redação de textos. Dada a complexidade do objeto do conhecimento, é imprescindível que seja incentivada a prática interdisciplinar. (BEZERRA, 2005, p. 42)

Em certa medida foi essa a dimensão com a qual os alunos operaram, ainda que de modo insatisfatório ou superficial. A realização deste exercício de produção fílmica denuncia uma adesão a uma determinada versão do ensino de História, em que aquilo que foi aprendido passa não somente pela escola, mas também por uma narrativa externa. A linguagem fílmica permite brechas na montagem, por meio do recurso à alegoria, pelas associações inconscientes estabelecidas com o imperialismo, o totalitarismo, o nacionalismo, a democracia, o povo, as possibilidades de composição da História por sujeitos nos quais os próprio alunos podem se reconhecer.

Essa busca de informações em fontes externas, caracterizada por pesquisas em livros, imagens, documentos eletrônicos, e também a análise desses documentos, a 
comparação das informações neles contidas, por vezes interpretações diferentes sobre o mesmo assunto, a formulação de hipóteses sobre esse assunto e o conhecimento e uso de diferentes medidas de tempo estão citados nos PCNs de História e Geografia (BRASIL, 2000, p. 57-58). Este procedimento relaciona-se, ainda segundo o texto oficial do governo brasileiro, com os objetivos do ensino de História para o segundo ciclo, dentre os quais está "utilizar diferentes fontes de informação para leituras críticas (BRASIL, 2000, p. 62).

Para dar conta desta proposta o projeto ofereceu alguns caminhos de ação, na medida em que o uso de uma linguagem no ensino de História foi o seu tema. Ao longo do ano letivo os alunos desenvolveram habilidades para operar especificamente com o cinema, e não apenas o utilizou para um trabalho qualquer. Buscou-se aqui uma apropriação da linguagem como objeto de estudo, capaz de oferecer uma modalidade narrativa; o cinema tornou-se fonte de informação tanto para leituras críticas, quanto para a produção de discursos críticos.

O fato de o cinema ser multifacetado pode tornar mais ampla a proposta de utilização de diferentes fontes - a partir de uma mesma obra diferentes elementos podem ser explorados. Isto ocorre porque um filme encerra a leitura da imagem - em movimento ou estática -, da trilha sonora, das falas das personagens, dos símbolos, da iluminação, das cores, etc. E além de poder trabalhar esses aspectos isoladamente, é possível fazê-lo de modo relacional. É nesse sentido, que o trabalho e os PCNs estreitam sua comunicação.

No caminho percorrido pelos alunos para se aproximarem dessa outras fontes de informação sobre a História, eles reconheceram a existência de uma memória individual e coletiva sobre o saber, e é nessa relação que criaram suas narrativas, expressas nos filmes.

Esse emaranhado de memória individual e memória coletiva prolonga nossa vida, fazendo recuar no tempo, e nos parece um promessa de imortalidade. Quando partilhamos dessa memória coletiva (através das histórias de nossos antepassados ou através de livros [outras fontes de informação]), somos como Borges contemplando o mágico Aleph . (...) E, assim, é fácil entender por que a ficção nos fascina tanto. Ela nos proporciona a oportunidade de utilizar infinitamente nossas faculdades para perceber o mundo e reconstituir o passado. (...) E é por meio da ficção que nós adultos, exercitamos nossa capacidade de estruturar nossa experiência passada e presente (ECO, 2006, p. 137).

\subsection{A construção das personagens}

Na seção anterior percebemos que os alunos operam com a composição de um enredo de modo que faça sentido frente às informações históricas que eles e os espectadores 
aos quais os filmes serão submetidos dominam. Nesse contexto, as personagens - sua caracterização física, atributos de personalidade, falas e atitudes - são parte integrante desse processo e sua construção, de importância fundamental.

Nos filmes 2/2007, 4/2007, 6/2007, 3/2008 e 4/2008, os alunos usaram bonecos adaptados para representar tanto o presidente Vargas quanto os demais envolvidos, sendo que se podem destacar as seguintes particularidades: o filme 1/2008 caracteriza o presidente brasileiro como um animal - o ursinho Pooh, usando uma faixa verde e amarela -, enquanto o 7/2007 o mostra como uma fruta (uma banana), na representação de uma personagem do desenho infantil Bananas de Pijama. Ambas as representações operam um simbolismo característico de um líder fraco - o ursinho Pooh é bonachão, ingênuo, infantil; ser um banana é ser alguém sem iniciativa, incapaz, frouxo.

Outros grupos fabricaram suas personagens usando ilustrações, recorte, colagem, massa de modelar, entre outros materiais. Essa construção está presente nos filmes 3/2007, 5/2007, 7/2007 e 2/2008. Neste conjunto, destaca-se a produção que mostra Getúlio Vargas como uma montagem de recortes fotográficos, com a roupa de um mosqueteiro - filme 5/2007. Nesse mesmo trabalho, observa-se que as demais personagens que interagem com o presidente são de um mesmo anúncio, da empresa Vale, porém da época em que ainda se denominava Vale do Rio Doce, talvez aludindo à lembrança de ter sido, com esse nome, uma empresa estatal. Sendo assim, esse símbolo pode ser associado ao nacionalismo característico de governos intervencionistas, como o de Vargas, mas também, em sua situação atual, sendo a Vale uma empresa privatizada, pode configurar uma ironia.

A presença do presidente como um mosqueteiro sustenta a imagem de protetor, mas aqui não é o rei ou a rainha que merecem esses serviços e sim, o Brasil, que corre o risco de cair nas mãos de Júlio Prestes, tido como inimigo. Também pode denunciar uma colagem quixotesca, ou seja, um herói fora de lugar, que para defender os bens nacionais - na representação da Vale do Rio Doce - estaria fadado à morte; não teria espaço na sociedade contemporânea. Essa leitura reforçaria a visão pequeno-burguesa, reproduzida nas famílias dos alunos, de um estado poderoso como algo démodé.

Nesse filme é possível perceber uma aparente confusão do grupo em relação ao nome das personagens. De acordo com a trama e o enredo, a oposição de Vargas é Luis Carlos Prestes, e não Júlio Prestes, mas o grupo não se dá conta da troca de nomes. É ainda curioso verificar de que modo apenas algumas personagens merecem identificação e reconhecimento, neste caso a do presidente. A memória sobre o ensino de História é capaz de selecionar os nomes dos heróis que devem ser estudados na escola, tal como se evidenciou 
nesse trabalho, no entanto os critérios de seleção dessas personagens são complexos, e no caso desse filme deixa passar a confusão entre os dois Prestes.

Essa leitura é um reflexo do ensino de História em que há um herói e só ele deve ser valorizado, sendo os demais figurantes, fiéis ao seu nome. É um saber centrado nos grandes homens, e diante da sobreposição de narrativas, essa imagem não é resultado apenas da ação escolar, mas de toda uma cultura familiar e midiática.

Outra construção de personagem que merece ser avaliada em particular é aquela usada no filme 7/2007, em que o presidente é uma Banana de Pijama fabricada com massa de modelar. A banana aqui seria um sinal da fragilidade política do presidente ou de suas ações? Para esclarecer essa interrogação talvez seja pertinente uma contraposição com o enredo. Neste, Vargas assume todas as suas ações políticas de enganação do povo e dos interesses norte-americanos e é acusado por Hitler, já condenado, de tê-lo abandonado.

Ser um banana, no caso, justifica-se frente à postura adotada em relação à política totalitária de Hitler, a qual em certa medida o presidente brasileiro copiava - seria um banana por ter o alemão como referência política. Também não se pode negar a referência ao universo infantil dos membros do grupo, a partir de uma série veiculada na televisão, em que os Bananas de Pijama eram uma dupla de irmãos, nem mesmo possuindo nomes - eram chamados apenas de B1 e B2. Poderia ser também uma acusação a Getúlio, de falta de identidade, de cópia européia? Neste sentido, a memória do ensino de História denunciada pelo grupo pode referir-se também a uma relação de subserviência dos encaminhamentos internos às determinações internacionais.

Essas considerações levam-nos à reflexão de que os alunos, em seus filmes, operam com o presidente Vargas em destaque, até certo ponto como um herói. No entanto, a criação de uma personagem que o represente na modalidade de narrativa fílmica nos oferece uma maior variedade de leituras, as quais não são puramente a confirmação do líder imaculado. De todo modo, é possível verificar uma sofisticação na aproximação que os grupos fizeram das informações históricas sobre o presidente, ainda que esta seja perceptível apenas em uma análise pormenorizada da composição das personagens.

Fazer história, como se propõe aqui, pode começar pelo que seria a inversão de um quebra-cabeças: o acontecimento pronto e acabado, que sempre compõe uma imagem que ambiciona abranger a totalidade do processo, deve ser decomposto para denunciar aos espectadores o arbítrio de sua construção, como se alguém mostrasse à platéia que fios invisíveis sustentam os truques de ilusionismo do mágico - tão sobrenatural quanto qualquer um de nós. (MICELI, 2006 p. 34) 
Na categoria de adaptação das personagens a bonecos de brinquedos destaca-se a zoomorfização de Getúlio Vargas como o ursinho Pooh, tal como se assiste no filme 1/2008. Essa caracterização se faz mais fértil quando o presidente brasileiro interage com o norteamericano, personificado no palhaço Ronald McDonald.

Por que Vargas é o ursinho Pooh? O simbolismo desta personagem remete ao universo infantil, como um animal glutão e pacífico, que mora na floresta com outros animais e um garoto e junto com os quais vive aventuras. A referência aqui é a ingenuidade do líder brasileiro diante da esperteza do norte-americano, ícone de marketing e representante da maior de suas redes de fast food? Nas cenas nota-se também que o representante norteamericano é bem maior que o brasileiro - embora o presidente brasileiro tivesse estatura baixa - , sendo mostrado, por vezes, somente da cintura para baixo, em uma tomada que lembra a de antigos desenhos como Tom \& Jerry, onde uma empregada apresentada nesta condição transmite a sensação de dominação e censura à dupla de protagonistas, isto é, do ponto de vista das crianças. Seria esta também a relação do governo norte-americano com o brasileiro, representado pelo ursinho Vargas?

É possível que a resposta a essas questões se encontre nos desenlaces da trama, uma vez que o ursinho Pooh fica com o dinheiro oferecido pelo norte-americano, mas também se aproxima da suástica e do nazismo, referindo-se a uma adesão econômica aos Estados Unidos e não à sua ideologia, a democracia.

A partir dessa configuração identifica-se um saber extra-escolar no qual a esperteza e a dissimulação são as armas dos mais fracos, ou seja, o presidente deve cultivar uma aparência de ingenuidade e subserviência frente à política internacional e buscar o melhor para o país. Em nenhum momento constam no material didático referências a este tipo de articulação. A constatação de que o ensino de História não é a única narrativa usada pelo aluno para compor imagens sobre o passado da nação é fundamental, posto que percebemos os limites do ensino.

No filme 5/2008, as personagens são construídas a partir da adaptação dos pés e das mãos das alunas do grupo, de acordo com o desenvolvimento do enredo. Há uma opção do grupo por essa representação - nas fotos dos bastidores da produção, observa-se a presença de bonecos que poderiam ter participado da trama, porém somente seus adereços foram utilizados, sendo as mãos e os pés das alunas, efetivamente, as personagens que compuseram as cenas. O grupo trabalha com alguns estereótipos para apresentar os tipos sociais que apoiavam o governo de Getúlio, caracterizando-os com roupas, chapéus e instrumentos de trabalho. 
É curioso que o recurso de usar mãos e pés não limita a expressividade das personagens envolvidas na trama - o próprio presidente Vargas é representado de diferentes modos, de acordo com o momento da narrativa. $\mathrm{O}$ recurso dos dedos dos pés com carinhas felizes desenhadas traz a multidão à cena, mas tal como ocorre em outros filmes, ela não tem identidade.

Esta escolha do grupo pode ainda indiciar um movimento de participação direta na História? A exigência de serem protagonistas? Um improviso material? O desejo de se exporem, fato talvez confirmado pela presença do making of? Estas questões se referem ao lugar que assumem no ensino de História ou na própria escola. O exercício de produção de filmes pode ter oferecido a este grupo em particular um canal de comunicação.

Atualmente os filmes na versão em DVD costumam trazer uma sessão, no menu, em contém informações extras; uma delas é o making of. O objetivo é trazer ao público informaçães sobre a produção do filme. O formato de apresentação é variado - podem ser os atores ou diretores em entrevista trazendo informações sobre a produção, a formação das personagens, imagens produzidas durante as filmagens, tal como em um exercício de metalinguagem, por exemplo, mostrando os erros de gravação; no caso de uma animação, podem ser apresentados o processo de criação, aspectos do avanço tecnológico associado ou a sonorização das personagens, frequentemente contando com a participação de atores consagrados. Essa mesma percepção de trazer para o espectador o universo por trás da câmera esteve presente em três filmes de 2008. São eles: 2, 3 e 5.

Os alunos revelam um saber intuitivo sobre o formato do cinema na organização dos créditos iniciais ou finais do filmes. Outro item que reforça esse saber extra-escolar que os grupos manipulam para seguir um padrão, facilitar comunicação e dar legitimidade ao trabalho realizado é a presença de créditos da produção. Não solicitei aos alunos que registrassem a participação de cada membro do grupo no filme, também não deixei espaço para agradecimentos. Mesmo sem ter obrigatoriedade, a maioria dos grupos segue a um padrão de ficha técnica: atores, trilha sonora, funções tais como: montagem, cenário, fotografia, roteiro, entre outros. Até mesmo no filme 3/2008 em que há referência direta a atividade como trabalho escolar, a ficha técnica é seguida.

Até mesmo a não-caracterização específica das personagens revela uma expectativa em relação a quem está assistindo ao filme: espera-se que eles tenham um repertório mínimo de informações para o entendimento da trama. É certo, ainda, que o título do filme não deixa muitas dúvidas sobre qual seria o protagonista. Outra possibilidade de entendimento desta questão é pela opção por trabalhar de modo alegórico com as 
representações que são atribuídas àqueles que estão presentes no filme, seja o presidente brasileiro, Hitler ou um líder norte-americano. Tratar-se-ia de um caminho que revela a capacidade de fabular, como um teatro para crianças, imagem confirmada pelo grande uso de brinquedos como personagens. Há um sentido aberto nessas escolhas, o qual varia em entendimento de acordo com o repertório dos sujeitos que assistem.

\subsection{A trilha sonora e a significação da cena}

A construção do filme também assume uma dimensão de comunicação com o espectador a partir do uso da trilha sonora. Em todos os trabalhos, o aluno que realizou a montagem - ou o sequenciamento das cenas - foi também o responsável pelos temas musicais utilizados. Em nenhum dos roteiros elaborados havia referência às melodias que seriam empregadas.

Uma das características pertinentes a essa experiência pedagógica foi a combinação entre as articulações possíveis para o ensino de História, a lógica de um currículo que se relaciona com saberes extra-escolares e também as especificidades da produção de um filme. Verifica-se que em alguns filmes a melodia é capaz de alterar a significação da cena, conferindo ao enredo novas possibilidades de encaminhamento e de interpretação.

De acordo com Marcos Napolitano (2006, p. 23), a experiência social do cinema traz algumas possibilidades interpretativas e, naquilo que se refere à música, é necessário analisar a trilha sonora como expressão de sentimentos, compreender a relação entre a música, o ritmo e o movimento imagético e também ater-se à letra, compreendendo-a como um discurso narrativo que assume o filme e veicula uma mensagem.

Em todas as obras produzidas pelos alunos há uma trilha sonora, mas o peso que ela assume em cada filme é variável. A diversidade de formatos da música compreende melodias instrumentais ou cantadas, nacionais ou estrangeiras, do repertório atual ou de épocas passadas, podendo mesmo serem dos anos de governo de Getúlio Vargas, inclusive fazendo alusão à sua figura. Essa última modalidade está presente nos documentários que o filme 3/2008 utiliza. Também é possível verificar sua utilização no filme 3/2007.

No filme 3/2008, a trilha sonora ocupa um papel importante na significação das cenas. A obra é basicamente dividida em dois momentos narrativos: o primeiro refere-se à participação do Brasil na Segunda Guerra Mundial e o segundo, ao suicídio de Vargas. Na primeira sequência há uma colagem de trechos de documentários, e é ai que encontramos uma 
articulação importante com a trilha sonora, posto que são mostradas canções oficiais do governo, com um discurso próprio sobre o conflito. Não são apenas as frases cantadas que compõem um sentido, mas também os ritmos - marcha e samba, que podem ser considerados demarcadores da identidade nacional brasileira. A cena de convocação de guerra ao ritmo da marcha confirma um ideal de disciplina, enquanto o ritmo de samba ameniza a violência do conflito nas cenas de combates.

Outra leitura pertinente sobre a trilha sonora ocorre na sequência em que o presidente se suicida. Sua morte poderia ganhar um tom de dramaticidade, sustentado pelas cenas do documentário incorporado à obra. Mas a escolha da música-tema do filme $O$ Poderoso Chefão permite uma leitura do presidente como um chefe mafioso, possivelmente associado a outros políticos. Essa música já faz parte do repertório de muitos espectadores de cinema - talvez possa aqui ser chamado de acervo clássico -, e evoca a cena em que a personagem de Marlon Brando é assassinada por outro grupo de mafiosos, por razões de disputa de poder entre grupos rivais.

É aqui que se identifica a relação que o grupo possui com o ensino de História, com uma percepção de elementos estruturais da política criando uma comunicação com o tempo, em uma dimensão de longa duração. A corrupção do governo seria uma característica de unidade e permanência entre as temporalidades e entre os espaços, uma vez que a trilha sonora é uma referência a uma cultura cinematográfica que tem nos Estados Unidos a sua maior referência, e o tema direto do filme é o Brasil.

Outros símbolos estão na cena para confirmar essa percepção, como é o caso do trono em que o líder se acomoda para disparar contra o peito. Trata-se de um trono adornado com ossos e um crânio no alto - pertencente à personagem dos quadrinhos chamada Fantasma, o que traz à lembrança o exótico de áreas remotas, um clichê do cinema -, tal como uma acusação ao presidente - rei da morte - ou como um signo do seu destino final. O enredo parece fechar neste ponto, uma vez que o primeiro momento do filme relata a convocação de brasileiros para lutar na guerra, feita pelo mesmo presidente - seriam os ossos do trono os mesmos dos soldados mortos em combate? O suicídio parece ser um sinal de justiça e o término de um ciclo, que continua aludido no uso da trilha sonora.

No filme 1/2007, a utilização da ária Cantilena, das Bachianas Brasileiras $n^{0} 5$ propicia uma leitura de adesão a um determinado período da História nacional. Nessa produção, em particular, há referência aos Cacos da Era Vargas, mas o líder em si não está em cena. Também não há outros elementos capazes de localizar o espectador no tempo, a não 
ser pela música. O espaço pode estar configurado no uso de inscrições em verde e amarelo, elementos canônicos da construção do nacionalismo.

O compositor da trilha sonora é Heitor Villa-Lobos, uma personagem importante na efetivação do projeto nacionalista atribuído ao governo de Getúlio Vargas - o maestro integrou, à época, a comissão de valorização e divulgação da cultura brasileira. A simples utilização dessa música em um filme onde o presidente Vargas não é visto já estabelece um sentido - é como uma presença transcendental que invade a cena, na voz da soprano Bidu Sayão, também um ícone da época.

Villa-Lobos desempenhou um importante papel na construção de um projeto nacional para o Brasil. Trabalhou na Secretaria de Educação de São Paulo e, depois foi convidado por Anísio Teixeira para dirigir a Superintendência de Educação Musical e Artística (SEMA) da Secretaria da Educação do Distrito Federal (RJ), onde criou um programa de Canto Orfeônico, o qual se difundiu por todo o país. Em 1942, criou o Conservatório Nacional de Canto Orfeônico. Nessa área, seu trabalho dirigia-se para a divulgação da cultura musical nas escolas e também para a afirmação da música folclórica como base da cultura brasileira autêntica.

Getúlio Vargas juntamente com o Departamento de Informação e Propaganda (DIP), conseguirá de certa forma utilizar o rádio e os sambas para "educar" e disciplinar os consumidores desse tipo de música. Isso se dará através da censura, dos sambas celebrando o trabalho disciplinado, do nacionalismo ufanista das canções de exaltação, dos grandes concertos promovidos pelo Estado e Villa-Lobos nos estádios de futebol e, em última instância, através dos concursos carnavalescos. (CUNHA, s/d, p. 11)

Toda essa intrincada relação de filiação da composição melódica a um determinado período da História foi uma ação consciente? Uma busca na Internet pelos termos música instrumental brasileira abre um caminho de possibilidades para esta seleção. Este encaminhamento denuncia uma memória sobre a História nacional em que já existe de antemão uma ligação entre nacionalismo, música clássica e Villa-Lobos.

Também é verdade que o tema das Bachianas $n^{0} 5$ tem sido usado exaustivamente como trilha sonora, por ser um símbolo representativo do brasilianismo, seja na publicidade ou no próprio discurso oficial. Ela faz parte de uma espécie de patrimônio musical inconsciente da cultura brasileira.

Ao refazer a pesquisa encontrei também links que direcionavam para Carlos Gomes, mas as referências foram em menor número. Os resultados de maior relevância direcionavam à produção cultural do Estado Novo. Diante desse quadro, percebemos que mesmo sem ter acesso às informações de produção cultural durante o governo Vargas, 
sonegadas no material didático e também na narrativa das aulas, os alunos puderam conhecêlas, ampliando o conhecimento do repertório cultural sobre a memória nacional. Aqui cabe um questionamento: onde os alunos aprendem História? As considerações realizadas até este momento já nos dão a certeza de que não é somente na escola. E qual é o peso da Internet como veículo de informação? É certo que há outras narrativas sobre o ensino de História no universo extra-escolar - no capítulo 2 deste trabalho Laville (1999) já chamou nossa atenção sobre a guerra das narrativas acerca de um mesmo evento histórico, bem como de que modo nascem credibilidades diferentes para fontes diferentes.

Há filmes em que a utilização da trilha sonora reforça a narrativa, combinando ritmo e letra, como é o caso da obra 6/2008. A música Que país é esse? enfatiza a perplexidade diante das atitudes do presidente, que parecem não combinar com a sua posição, uma vez que revelam uma determinada subserviência aos Estados Unidos. Verifica-se, portanto, uma simultaneidade de discurso: vemos uma cena que nos causa estranhamento e a trilha sonora reforça a significação desse mesmo estranhamento.

O fato de a música ser cantada por um grupo de rock dos anos 1980 também permite uma leitura, uma vez que ao longo dessa década nasceram no Brasil bandas de rock formadas por músicos de classe média, com letras que refletiam sobre o ambiente urbano, as mazelas da política nacional e internacional. É o caso de Renato Russo que compôs a música.

Outra modalidade importante de uso da trilha sonora é aquela pertinente à criação de movimento do filme, ou seja, o desenrolar das cenas combina-se a um desenvolvimento evocado pela melodia e pelo ritmo das músicas. Essa relação pode ser exemplificada pelo filme 6/2007, em que a música - um rock instrumental, sem identificação nos créditos - leva o enredo a um sentido de agitação constante e de um encadeamento natural das cenas. Até mesmo a alteração do ângulo da câmera reforça o sentido de aceleração do tempo histórico.

Como um texto pode impor um ritmo de leitura? Vamos entender isso melhor no que acontece em arquitetura e nas artes figurativas.

Costuma-se dizer que existem formas de arte nas quais a duração e o tempo desempenha um papel específico e o tempo do discurso coincide com o "tempo de leitura"; isso ocorre na música, sobretudo, e no cinema. O tempo do discurso num filme não coincide necessariamente com o tempo da história, ao passo que na música há perfeita harmonia entre os três tempos (a não ser que se queira identificar a história com o tema ou a sequência melódica, o enredo e o discurso com um tratamento complexo desses temas, através de variações ou flashbacks de temas anteriores, como é o caso de Wagner) (ECO, 2006, p. 64).

O ritmo alucinante, nesse trabalho, não deixa espaço, na organização do discurso, para maior esclarecimento dos fatos. Há um sentido aludido na combinação do enredo e da trilha sonora: a percepção de uma História sequencial, feita por meio de uma justaposição de 
fatos, que não estabelece relação entre eles. Até mesmo a cena do suicídio do presidente é apresentada sob o som dessa música, de modo que a dramaticidade do evento é solapada pelo som da guitarra, a qual também silencia outro discurso que não aquele apresentado na narrativa.

Novamente a trilha sonora reitera o caráter de simplificação da História, em uma modalidade totalizadora, onde os fatos são apresentados de modo linear, sem dar voz a outros sujeitos. O som forte rouba os possíveis pontos de diálogos entre as personagens que se encontram nas cenas. No formato de ensino de História que os alunos recebem nessas escolas não há espaço para sua atuação, ou seja, para suas investigações e conclusões, já que as atividades vêm prontas. Também podemos indicar certo tom de autoritarismo dos alunos, que não permitem às personagens falar. No momento em que trazem à cena tipos de trabalhadores que assistem ao discurso do presidente há uma crueldade particular em demonstrar certo preconceito de classe. Apenas aos trabalhadores são aludidas as causas das mazelas sociais o trabalhador bebe demais e acaba caindo, outro sofre um acidente ao ser acertado por um instrumento de trabalho, tudo ao som do rock - a ele caberia também a tarefa de remediar o sentido de tragédia?

Nessa simplificação da narrativa histórica há diferentes sujeitos - o grupo reconhece os exploradores e os explorados, mas não segue, em sua análise, para além desta constatação e o humor se direciona apenas aos pobres, provável lugar-comum ou imagem significativa para um grupo formado por alunos de classe média da escola A.

A utilização da trilha sonora para sustentar a narrativa do filme fica evidente também no filme 2/2007, o qual utiliza duas canções, a primeira mais calma para acompanhar a informação dada no início do enredo - de que a cidade era pacífica - e a segunda, um rock, que agita a trama, acelerando a sequência de apresentação das realizações do novo governo. No final, a primeira melodia retorna, enquanto se lê na tela um sequência de palavras de ordem.

Nesse filme, as melodias utilizadas anunciam uma História constituída por ações governamentais, de modo que o curso dos acontecimentos é de responsabilidade do dirigente, tal como um maestro. A trilha sonora, bem como sua combinação com o enredo apresenta um ritmo de informações aceleradas, combinadas com uma música de caráter de agitação, levando o espectador a um tempo que urge. Essa composição parece sugerir uma minimização da luta de classes, ou seja, da ação de resistência do trabalhador frente às situações absurdas descritas, pois a música e os eventos atropelam o espectador com uma sequência de informações acerca das ações trabalhistas do presidente, mostrando uma ingenuidade do 
eleitor, o qual não reage. Todo esse movimento político e social do período Vargas relacionase com o que nos escreve Cunha:

Para minimizar a força que as classes subalternas, especialmente o operariado urbano, haviam adquirido na década de 1930, o Estado Novo atendia a algumas antigas reivindicações da classe, assim como difundia uma série de mensagens elaboradas de modo a ocultar o passado de luta dos operários e obscurecer suas reais condições de existência. Uma das formas de ocultar a capacidade de ação das classes consistia na repetida divulgação do caráter do povo brasileiro, apresentado como portador de "índole tradicionalmente pacífica", criando assim, a imagem de um caráter nacional incompatível com quaisquer conflitos e lutas. Passa-se então a formar uma "concepção de trabalho" segundo a qual não se distinguiam atividades manuais das intelectuais e o trabalho passou a ser não apenas um meio de "ganhar a vida", mas sobretudo um meio de "servir à pátria". Os movimentos sociais eram assim apresentados como excepcionais, resultantes da infiltração de estrangeiros ou da ação de pequenos grupos. É importante ressaltar a infiltração de estrangeiros ou da ação de pequenos grupos (CUNHA, s/d, p.12).

O grupo trabalha com a História dos vencedores, com uma ação que só se concretiza a partir da atitude do líder. O povo funciona como marionete; no entanto, a constatação revela a possibilidade de emancipação frente a esse conhecimento do passado. Aqui o estudo da História traz a denúncia da injustiça e da inércia da exploração. A solução é a alteração de sua lógica, com a ação, ainda que esse caminho não seja claro para o público.

No filme 2/2008 a utilização da trilha sonora confere importante significação ao enredo e ao próprio objetivo do discurso, ou seja, o filme já tem seu clima anunciado com o tema da Pantera Cor-de-Rosa. Trata-se da apresentação de um mistério e, ao mesmo tempo, seu encaminhamento a uma explicação fantástica, efeito sustentado pela melodia, que tem um clima de suspense. Como esclarece Umberto Eco, "em toda obra de ficção, o texto emite sinais de suspense, quase como se o discurso se tornasse mais lento ou até parasse, e como se o escritor estivesse sugerindo: 'agora tente você continuar..."” (ECO, 2006, p. 56).

Desse modo, é reforçada a dúvida que o grupo lança sobre uma versão para o suicídio de Vargas, a qual está atrelada ao atentado a Carlos Lacerda. Na mesma tônica seguese o uso da música Sociedade Alternativa, como lembrando ser possível outra versão para a História.

\subsection{A fabricação da legitimidade}

Para desenvolver um exercício que se comunicasse com a legitimidade, acreditei ser necessário poder identificar nas produções dos alunos as representações que eles 
possuíam. Para tanto, era preciso não imprimir um caráter prescritível às atividades e também retirar a interferência do peso da nota de avaliação e da obrigatoriedade. Portanto, a produção dos filmes seria uma atividade de adesão livre, ou seja, da qual os alunos somente participariam se desejassem.

Mas de que modo cada grupo que aderiu à proposta vivenciou esta realidade ao longo do ano? Talvez possamos localizar uma pista para a resposta nos próprios filmes produzidos, já que não realizei entrevistas e nem mesmo foi objetivo inicial deste trabalho explorar o impacto de um trabalho livre. Seria possível afirmar que o fato de o trabalho ter adesão livre conferiu ao projeto liberdade narrativa?

Nos filmes 7/2007 e 3/2008 é possível ver uma indicação nos créditos que vincula a obra a um trabalho escolar. Poder-se-ia especular que este fato indicia uma menor autonomia do grupo. Porém percebemos que os discursos desenvolvidos pelas duas produções parecem não confirmar esta hipótese. O primeiro trabalho apela a um recurso alegórico, criando um contra-discurso da carta-testamento, algo que não parece típico de uma ausência de autonomia. No segundo caso, embora haja uma reiteração no enredo sobre as informações do discurso oficial, existe uma presença de autonomia na forma como foi feita a montagem do filme pela presença de trechos de documentários da época, possibilidade que não havia sido indicada por mim.

Há ainda filmes que evocam a legitimidade a partir da filiação da produção à escola. Isto ocorre em 3/2007, 1/2008, 4/2008 com indicação nos créditos. É possível identificar certo pertencimento a instituição, talvez como uma manifestação do habitus do estudante, talvez como uma referência de segurança para veicular um discurso.

Quatro filmes não se ocuparam em comunicar ao espectador a natureza da atividade. São eles: 4/2007, 5/2007 e 6/2007 e 6/2008. Outro conjunto de filmes se furta de citar a natureza do trabalho, ou a instituição escolar em que foi desenvolvido, ou ainda o faz, mas também se refere à professora, são eles: 1/2007, 2/2007, 3/2007, 1/2008, 2/2008, 4/2008 e 5/2008. É possível que a referência do trabalho e da proposta seja a professora, uma referência pessoal, e não à instituição escolar, ou ao ensino de História.

Os filmes produzidos pelos alunos constituem-se em uma modalidade narrativa de ficção, ou seja, tomam alguns conteúdos históricos como elementos de encaminhamento para uma abordagem do tema, mas sem compromisso necessário com a verdade histórica, por essa razão marca-se a ideia de ficção. Não há a intenção de se constituírem em um discurso fechado, pelo contrário, elas dialogam com a memória e o ensino exercitados tanto na escola 
quanto fora dela, e é a partir dessas considerações que tratarei agora do tema da construção da legitimidade dos discursos.

No caso, a produção dos alunos também se identifica como ficcional, na medida em que

A narrativa artificial é supostamente representada pela ficção, que apenas finge dizer a verdade sobre o universo real ou afirma dizer a verdade sobre um universo ficcional.

Em geral, reconhecemos a narrativa artificial graças ao "paratexto" - ou seja, as mensagens externas que rodeiam um texto. (...)

Parece que a ficcionalidade se revela por meio da insistência em detalhes inverificáveis e intrusões introspectivas, pois nenhum relato histórico pode suportar tais "efeitos de realidade" (ECO, 2006, p. 126-128).

Pensar a respeito deste assunto é como se questionar a respeito da forma e dos recursos utilizados pelos alunos para garantirem que o filme que produziram seja decodificado pelo público que irá assisti-lo na escola e também criar uma unidade de sentido com a função primeira de convencer, inclusive, a professora.

Há ainda outra possibilidade de comunicação: a veiculação dos filmes no portal do YouTube. Esta realidade cria outra configuração a produção será vista por um público externo, ou seja, trata-se de um grupo que não está envolvido no projeto, e não conhece as características daquela atividade - no acesso a partir da referência profadani é possível ler um pequeno esclarecimento sobre a natureza do trabalho como uma produção discente nas aulas de História, os quais são objetos de análise em uma dissertação e mestrado. No início da atividade foram os próprios alunos que postaram os filmes para o acesso na internet em contas pessoais, eu só realizava essa tarefa no final do ano quando todos os grupos já havia entreguem os trabalhos.

Nesse sentido, a narrativa dos grupos em cada um dos filmes ganha amplitude comunicativa e crítica, uma vez que o espectador pode postar um comentário sobre suas impressões. Aqui também se verifica a criação de uma espécie de memória sobre o trabalho, algo que fica registrado em uma esfera de acesso imediato, não foi um trabalho escolar que virou arquivo morto.

Os alunos constroem a legitimidade do filme a partir da operação de cenas e temas que são facilmente reconhecidos pelo público, garantindo uma aceitação mínima da sua mensagem.

O que está em ação aqui é uma relação circular e oculta entre aqueles que fazem filmes e aqueles que assistem a filmes, uma região que nunca é vista por ninguém, mas que é uma província de muitos olhos. Os cineastas, que são eles próprios espectadores de filmes feitos por outros, têm uma vaga ideia sobre se serão ou não compreendidos por seus contemporâneos. Estes 
últimos, por sua vez, se adaptam (involuntariamente, com frequência de modo inconsciente) a formas de expressão que por um breve período parecem ousadas, mas logo se tornam lugares-comuns. O primeiro homem a fazer a imagem tremer a fim de indicar uma mudança na percepção foi um verdadeiro inovador. $\mathrm{O}$ segundo copiou o primeiro, talvez aperfeiçoando o processo. Na terceira vez, o efeito já era um clichê (CARRIÈRE, 2006, p. 21).

De modo geral, pode-se classificar a construção da legitimidade dos filmes em duas categorias abrangentes: uma refere-se a uma forma específica de tomar para si o conteúdo veiculado pelo ensino de História e outra trata da reconstituição de um modo particular de abordar a História, cara ao historiador, que sustenta suas argumentações em vestígios selecionados do passado. Há por assim dizer, nesta última modalidade de articulação de uma verdade presente no filme, uma aproximação sofisticada com o saber - a criação de um método para organizar as informações.

Em ambos os casos há uma escolha por determinados recortes temáticos, diante do período histórico sugerido pela professora, o que já determina ou estreita os limites e possibilidades de interpretação. essa seleção respeita critérios pessoais, bem como a percepção do grupo para um tema que suscita possibilidades de construção da imagem e também de comunicação. Mas essa organização passa também por uma memória do ensino de História que cria padrões e gera discursos canônicos. Respeitar a ordem dos conteúdos previstos no material didático também é um caminho seguro, inclusive se considerarmos as características da organização escolar na qual os alunos que participaram deste projeto estão inseridos.

Os filmes 1/2007, 2/2007, 4/2007, 5/2007, 6/2007, 1/2008, 2/2008, 5/2008 e 6/2008 sustentam sua legitimidade na utilização de um tema ou de uma informação histórica estudada em sala de aula, ainda que esta sofra alteração na organização da narrativa. Em nenhum deles há o aprofundamento desse tema ou a sua composição com outras versões. Antes operam com um saber possível de ser identificado pelos espectadores no ambiente escolar, afinal essa dimensão também receberia um destaque importante.

No filme 1/2007, a filiação a um determinado tempo e espaço ocorre com o uso da trilha sonora do tema das Bachianas Brasileiras $n^{\circ} 5$. Mesmo sendo uma correspondência indireta, que exige daquele que assiste certo repertório sobre o assunto, a informação é veiculada sem explicações de como se deu essa associação - entre canção e formação do nacionalismo brasileiro.

No filme 2/2007, os elementos inteligíveis são referentes ao trabalhismo criado por Getúlio Vargas. O simbolismo trazido na imagem da carteira de trabalho oferece um 
reconhecimento imediato. Esse encaminhamento segue um tom quase militante, ao proclamar o fim de um ciclo de exploração dos trabalhadores, contribuindo para isto algum discurso obtido na mídia - propagandas políticas, noticiários sobre projeto de flexibilização da CLT etc. -, informações do material didático, destacando conquistas trabalhistas como resultado da ação do estado, personificado na figura de Vargas, e memória familiar.

O filme 4/2007 sustenta sua legitimidade a partir da participação do Brasil em um conflito armado, identificado imediatamente como a Segunda Guerra Mundial, com as imagens da ação da Força Expedicionária Brasileira e da Força Aérea Brasileira, comandadas pelo presidente Vargas. A associação não é direta, mas funciona como uma reconstrução a partir de lacunas que devem ser completadas pelo espectador.

No filme 5/2007 há um equívoco na narração - uma confusão entre o nome de um dos personagens da trama - Júlio Prestes - e Luís Carlos Prestes. Tal fato pode ser devido à coincidência da existência de dois Prestes em 1930, embora um seja líder popular e o outro um líder da oligarquia paulista. Tal como o achatamento da História, há a aproximação de duas personagens - contemporâneas, porém de características distintas - pelo efeito do homônimo em seus sobrenomes. Obviamente, as alunas do grupo não perceberam a falha do enredo. A busca pela legitimidade se dá apenas pelo uso do nome dos sujeitos históricos, ainda que o perfil de cada um deles seja distinto.

A busca de veracidade no filme 6/2007 se dá com a utilização de diversos fatos mencionados pelo material didático, mesmo que haja interferências de sentido na construção das informações que são veiculadas pelo filme. Um exemplo é a ação populista do líder brasileiro, que interage com a massa de trabalhadores de modo satisfatório - na metáfora criada pelos alunos, ele mesmo lança bolacha recheada ao povo, que se distrai e se interessa pelo agrado. Há aqui uma possível alusão simbólica à política do pão e circo da Roma antiga, relacionando-a ao populismo - real - do governo Vargas.

Igualmente, nesse filme, houve a citação da criação da Petrobrás, o que é um fato histórico, mas a leitura do grupo avança e cria uma situação fantasiosa em que o presidente dos Estados Unidos tenta comprar a empresa brasileira. Deste modo, o uso de informações reais permite ao grupo maior autonomia para realizar uma extrapolação. Na sequência da encenação do suicídio do presidente - fato histórico -, o filme apresenta um homem misterioso entrando no quarto de Vargas e roubando algo. É assim que realidade e fícção se fundem ou confundem.

A verossimilhança que assume maior simbolismo está presente no filme 1/2008. A proximidade entre a suástica e o sigma representa a proximidade entre as propostas 
políticas do nazismo e do integralismo. O telefonema para o presidente Vargas, em alemão, tem o objetivo de garantir ao público a presença de Hitler, não fisicamente, mas por meio do áudio. Há uma necessária identificação de Ronald McDonald com o imperialismo norteamericano, para que o discurso provoque o efeito de mostrar a sagacidade do presidente brasileiro, que manifesta, por interesse econômico, seu apoio à democracia capitalista estadunidense, mas por simpatia ideológica, mantém-se próximo à ditadura alemã.

Na composição da narrativa do filme 2/2008, o público reconhece como verdade o tema do suicídio, bem como a explicação imediatista que o material didático veicula com a justificativa para a decisão do presidente. No entanto, é exatamente a suposta adesão a essas informações que merece a desconfiança do grupo, manifestada na obra. O conteúdo histórico é de tal modo explicitado que provoca seu desgaste. A rapidez da cena e sua articulação com a trilha sonora provocam a relativização da verdade.

No filme 6/2008 a veiculação da informação histórica vem na primeira página de um jornal contendo as cores verde e amarela, suas ilustrações apenas confirmando o texto. Os conteúdos históricos referenciados são a presença da chamada política do café-com-leite, a qual deixa a cena política para a chegada de Vargas. De modo representativo e sutil, uma jarra de leite e um saco de café são deslocados no filme. O valor de marco inaugural para este acontecimento é reforçado no filme. A transição se faz sem referência ao sentido revolucionário atribuído aos eventos de 1930, informação inaugural no material didático sobre o início da Era Vargas e também marco canônico do ensino de História, como já foi referido no capítulo 2 deste trabalho.

A estratégia para conferir legitimidade ao filme 5/2008, onde as personagens são as mãos e os pés das alunas, é não somente a fidelidade a algumas informações, mas também a sua apresentação em ordem cronológica, o que viabiliza o entendimento do espectador. Esta escolha demonstra a adesão fiel à narrativa da História na escola, bem como ao formato do material didático.

A sequência inicial, assim como no filme 6/2008, traz a referência à Revolução de 1930, mas não por meio do fim da política do café-com-leite, e sim da disputa eleitoral entre Júlio Prestes e Getúlio Vargas, confirmando a eleição do primeiro. A transição para o governo de Vargas ocorre a partir de uma mudança no curso natural da história, pois o mandato devia ser de Prestes. A satisfação do novo presidente merece o destaque de sua face tranquila. $\mathrm{Na}$ exposição cronológica, aparece a definição de um governo dito de coalizão, ou seja, em que diferentes grupos sociais participam da administração, exatamente como consta no material didático e no encadeamento lógico estudado em aula. A sequência narrativa, porém, dá um 
salto e chega à morte de Getúlio, não como um suicídio, mas como uma consequência de suas obras.

O preciosismo do grupo nas primeiras etapas do governo exige do leitor ou do espectador do filme o domínio dos demais fatos pertinentes a seus mandatos, para acompanhar o desfecho. Aqui também há uma sonegação de informação - ocorre a morte, mas as justificativas ou o autor não estão em cena. A dedicação da obra aos bastidores se propõe a compartilhar com o público o percurso de realização, evidenciando os procedimentos seguidos para a produção do filme.

Uma das habilidades do cinema é exatamente conferir sentido a uma narrativa marcada pela descontinuidade. A própria linguagem treina o olhar do espectador para esse fim:

As imagens estão definitivamente separadas e, na passagem, temos o salto; mas a combinação é feita de tal modo que os fatos representados parecem evoluir por si mesmos, conscientemente. Isto constitui uma garantia para que o conjunto seja percebido como um universo contínuo em movimento em relação ao qual nos são fornecidos alguns momentos decisivos. Determinadas relações lógicas, presas ao desenvolvimento dos fatos, e uma continuidade de interesse no nível psicológico, conferem coesão ao conjunto, estabelecendo a unidade desejada (XAVIER, 2008, p. 30).

Outro conjunto de filmes trouxe uma percepção distinta para a construção da sua legitimidade, apoiada não apenas na confirmação de um conjunto de informações que pertencem à memória do ensino de História, mas também na explicitação de um método. Trata-se dos filmes 3/2007, 4/2008, 7/2007 e 3/2008. Nestes 4 filmes, a legitimidade do discurso se apoiou na utilização de documentos do passado. Veicular imagens ou trechos de áudio produzidos na época em que ocorreram os fatos rememorados no filme pode ajudar a caracterizá-lo como verdadeiro. Este costuma também ser um recurso utilizado na maioria dos documentários e nas reportagens históricas apresentadas na TV, nos canais pagos e nos canais abertos.

No filme 3/2007 o recurso utilizado é o áudio. Para sustentar a presença de Hitler no palco há a reprodução de um discurso do líder à juventude hitlerista, sem que haja preocupação com o teor da mensagem. Podemos supor que os alunos tenham a percepção de que a estética nazista é reconhecida pelo espectador apenas pela entonação da voz e pelo som do idioma - isto também foi explorado na análise do filme $O$ Grande Ditador, em que Hinkel se pronuncia de modo caricatural. Afinal, Hitler foi talvez o primeiro líder a utilizar, à exaustão, o potencial do rádio - e também do cinema - para a política. Assim, a sua voz, o seu 
modo de discursar, o seu gestual, acabou sendo reconhecido não só na Alemanha, mas em quase todo o mundo.

O mesmo procedimento é empregado quando o palco é ocupado por Vargas ouve-se uma marchinha criada pelo Departamento de Imprensa e Propaganda, responsável pela censura durante o Estado Novo, que traz em sua letra louvações ao presidente. Essa seleção confirma a capacidade de reconhecimento da massa a ambas as personagens.

No filme 3/2008, a legitimidade é buscada exibindo-se cenas de documentários de época sobre a participação das tropas brasileiras na Segunda Guerra Mundial, enquanto no filme 4/2008 esta se dá por meio da utilização, como cenários, de fotos das instalações reais onde ocorreram os fatos narrados. Deste modo, as sequências ocorrem em um cenário referido como real, ou seja, a cada bloco argumentativo um novo lugar é referido - a rua Toneleiros, para o atentado a Carlos Lacerda, a fachada do palácio do Catete para as manifestações públicas, ou o seu interior para a cena do suicídio. O trecho final da carta-testamento de Getúlio Vargas também é lido, conferindo legitimidade a esse último segmento da narrativa.

A perseguição de uma reconstituição do passado marca a ilusão de um ensino de História e também do cinema documental, ao mesmo tempo em que se pode dizer que no filme que se dedica a sustentar suas informações em documentos, há uma ingenuidade de se imaginar que essa seleção possa ser imparcial.

Há, portanto, nesse conjunto de filmes, uma percepção das características do ofício do historiador e do cientista de modo geral, que assinalam que sua argumentação deve estar alicerçada em alguma forma de comprovação - no caso, uma amostra de documentos que sustente cada afirmação. A utilização que cada grupo faz do documento é um indicativo do grau de conhecimento de um métier e também da importância atribuída às fontes. Seu conteúdo pode ser apreendido de modo positivista, segundo a crença de que o documento fala por si próprio - as informações que nele constam são a realidade -, ou também por meio da relativização das informações. Este último é o caso do filme 7/2007, em que a cartatestamento está presente em respeito a sua canonicidade, configurada a partir de sua exposição no material didático, mas seu teor é reconstruído, alterando sua significação. Até mesmo para refutar o teor da carta, foi necessário avisar ao público que foi encontrada outra carta-testamento. Ora o documento prova uma interpretação, ora alude a uma nova percepção.

Outro aspecto que interfere na busca pela legitimidade do discurso é o fato de as produções serem veiculadas na internet. A necessidade ou o desejo de tornar o filme público lhe impõe algumas características narrativas. A certeza de que a obra será exibida a outrem estabelece uma atenção, ainda que intuitiva, no caso dos alunos, à aceitação de seu discurso, 
isto é, uma preocupação com a capacidade de compreensão do espectador, através da identificação de coerência da mensagem do filme.

Uma das possibilidades da construção dessa coerência é operar com imagens contendo significação pretérita - clichês, conforme anuncia Eco (2006, p. 133).

Também é de nosso conhecimento que, para incrementar o enredo, os roteiristas colocam no filme todos os clichês da narrativa cinematográfica, transformando-o por assim dizer, num museu para os aficionados. Por essa razão, o filme pode ser usado como kit para montar arquétipos.

Nos filmes 2/2008, 3/2008 e 5/2008 é possível verificar a existência de um making of - uma sequência anexa ao filme que mostra os bastidores da produção. No filme 3/2008, por exemplo, é possível ouvir a estratégia do grupo na montagem do filme e a participação que cada membro teve naquela etapa da produção. A inclusão desse discurso explicativo sobre a produção pode ser entendida também como uma forma de legitimá-la, pois alguns filmes comerciais, em especial aquelas cópias em DVD, trazem no menu os extras, nos quais frequentemente está o making of.

\subsection{A questão do gênero}

A tomada dos filmes como objeto de análise permitiu alguns encaminhamentos, em geral, centrando as considerações no conteúdo e na forma.

Mas há outra dimensão que deve ser levada em conta, mesmo que sua sustentação seja complexa: a questão do gênero dos componentes do grupo de alunos que produziu o filme. Não pretendo aqui falar de produções realizadas por meninos e meninas, mas há outros aspectos a serem considerados.

As referências a questão de gênero não serão feitas para classificar esta ou aquela produção, mas para trazer elementos que enriqueçam a percepção acerca dos sujeitos que produziram os filmes, bem como os localizem como um elemento das relações estruturantes, com possibilidade de indicar caminhos específicos de sua visão de mundo.

O conceito de gênero consolidado na expressão relações de gênero representa a aceita de que a masculinidade e a feminidade transcendem a questão da anatomia sexual, remetendo a redes de significação que envolvem diversas dimensões da vida das pessoas. Comporta a permanente interdependência entre o biológico e o psicossocial em cada cultura 
específica (PINHEIRO ${ }^{28}, 2001$ apud TRAVERSO-YÉPEZ; PINHEIRO, 2005, p. 148).

A concepção de gênero é constituída socialmente, ou seja, assumo como eixo analítico a concepção sócio-cultural, mas reconheço que existem outros trabalhos em que também se trata a possibilidade de existir uma constituição bioquímica distinta para homens e mulheres. Ainda que este debate não seja pertinente, reconheço esse outro encaminhamento de estudo.

Em ampla investigação sobre as construções do sexo e do corpo sexuado, Anne Faus-Sterlling (2000) - professora de biologia e estudos de gênero do Departamento de Biologia Molecular e Celular e Bioquímica da Universidade Brow, em Rhode Island, Estados Unidos - cita inúmeras pesquisas que atestam a existência de uma anatomia cerebral específica para cada sexo. Daí viria o fundamento para atribuir às mulheres e a seu largo corpo caloroso a intuição, a falta de aptidão para ciências exatas, a ampla habilidade verbal e o uso simultâneo de ambos os hemisférios cerebrais. Aos homens, em geral, atribui-se melhor desempenho espaço-visual, matemático e científico. Articulando biologia, medicina e ciências sociais, a autora revela ainda usam as relações sociais para estruturar a natureza e, ao mesmo tempo, reduzem o mundo social a ela. (FINCO, VIANNA, 2009, p. 267)

Gênero remete a uma dinâmica de transformação social, aos significados que vão além do corpo e do sexo biológico e que subsidiam noções, ideais e valores nas distintas áreas da organização dos sujeitos. As afirmações biológicas são válidas, pois o conhecimento científico também é construído socialmente.

No processo de análise foi perceptível alguma relação de enredo e forma específicos em grupos masculinos e femininos. Da amostra de 13 filmes, 2 foram produzidos por meninos, 7 por meninas e 4 por um grupos mistos.

Portanto, destaca-se a existência de uma amostra maior de filmes produzidos por meninas. A maior adesão do grupo feminino à atividade vem de encontro ao trabalho Meninas bem-comportadas, boas alunas, meninos inteligentes, indisciplinados (SILVA et al., 1999), sobre o percurso de sucesso e fracasso escolar e sua relação com o gênero. A pesquisa se dá a partir de entrevista com professores para constatar o imaginário em torno da questão. No entanto, é curioso grande envolvimento das meninas na atividade.

Uma das características de gênero relacionada com o saber é a suposta preferência por áreas do conhecimento que são atribuídas a cada um dos sexos. Às meninas afirma-se a preferência pela área das humanidades, enquanto os meninos manifestam a preferência pelas ciências exatas e atividades esportivas. Nesse sentido, os dados obtidos no presente trabalho

28 PINHEIRO, V. S. Maternidade na adolescência: significados e repercussões. 2001. Dissertação (Mestrado em Psicologia) - Programa de Pós-Graduação em Psicologia, Universidade Federal do Rio Grande do Norte, Natal. 
podem concordar com essa percepção dos professores: de fato, as meninas se envolveram mais na proposta de desenvolvimento nas aulas de História; no entanto, não é possível averiguar a participação dos meninos em outras áreas.

Outra percepção dos professores - as meninas são mais dedicadas, detalhistas e dedicadas à arte - acabou por não se confirmar neste trabalho: Os filmes 6/2007 e 3/2008, realizados por meninos, também evidenciam a dedicação ao detalhe, em particular na fabricação de cenários e personagens. Na obra 6/2007, por exemplo, a confecção dos cenários chama a atenção pela caracterização dos ambientes, em particular na presença de um quadro com pintura abstrata, um tapete e um criado-mudo no quarto onde Vargas se suicida; a mesma riqueza ocorre na fabricação de uma tribuna usada no pronunciamento do presidente.

Também se destaca o fato de que o filme 3/2008 foi entregue antes do prazo. Aqui as características de gênero vão além dos seus perfis tradicionais; elas abrem possibilidades que precisam ser verificadas. Há uma atenção particular na montagem do cenário onde ocorre a batalha, e também na sala em que o presidente se suicida - nela existe até mesmo uma planta. Há também um corrimão na escada por onde Vargas sobe.

Outra temática associada ao universo feminino - o comércio em lojas - foi abordada em uma produção de alunas: o filme 5/2007. Nele é trabalhada uma metáfora a respeito de uma disputa entre lojas. A cultura do consumo está presente especialmente no cotidiano das meninas da escola A, de acordo com a explicação do perfil dos alunos no primeiro capítulo - justamente onde estudam as componentes do grupo que produziu esse filme -, pelo seu maior poder aquisitivo. Os produtos comercializados pelas lojas, entretanto, não são, em absoluto, convencionais e muito menos identificados com a realidade de consumo das meninas: armas. O tráfico de armas é um tema delicado e uma alegoria até certo ponto violenta e sua utilização pode ter sido uma maneira de as meninas se rebelarem contra o próprio lugar-comum onde elas são colocadas, como consumistas. De qualquer forma, o comércio de armas em lojas com vitrines e cartazes suaviza, de certa maneira, o impacto da mensagem.

Aliás, a opção pela construção de uma narrativa onde a violência é amenizada por meio da não-explicitação do ato agressivo parece ser uma marca dos filmes produzidos por meninas. Nesse sentido, verifica-se que as obras 4/2007, 4/2008 e 6/2008 possuem essa mesma característica. Na primeira, temos destruição sem morte; na segunda, o suicídio de Vargas não tem sangue nem som de tiro; e na última, há a participação do Brasil na Guerra, mas os soldados não caem mortos nem feridos. Essa percepção fica mais evidente quando se 
compara esses filmes aos produzidos pos grupos masculinos, onde a violência é mais explícita.

Talvez a constatação de um universo peculiar a determinado gênero fique mais evidente na análise do filmes 6/2007 e 3/2008. Estes foram produzidos por grupos compostos exclusivamente por meninos e a sua característica comum é a violência explícita e explorada à exaustão nas cenas. Há inclusive certas sequências ou tomadas onde a dor é privilegiada - é o caso do filme 6/2007, em que um trabalhador é decapitado em consequência de um atropelamento, ainda que essa informação não seja relevante para o entendimento da trama.

Scott, a respeito das relações entre de gênero e saber, nos escreve:

Tal saber não é absoluto ou verdadeiro, mas sempre relativo, ele é produzido de maneira complexa no interior de epistemes que têm, elas próprias, uma história autônoma (ou quase...) O saber é um modo de ordenar e, como tal, não antecede a organização social mas é inseparável dela... Gênero é a organização social da diferença sexual... é o saber que estabelece significados para as diferenças corporais (SCOTT, 1994 apud SILVA et al., 1999, p. 212).

Existem dois filmes - 3/2008 e 5/2008 - nos quais os alunos se dedicam a apresentar os bastidores do trabalho, e também estes podem ser avaliados pela questão de gênero, uma vez que foram realizados por um grupo masculino e feminino, respectivamente.

De acordo com o trabalho de Silva (1999), os professores por ele entrevistados mostraram possuir um discurso que associa a dedicação feminina aos estudos à maior participação das mães, tanto no controle das atividades, quanto no tempo que estas passam com as filhas. Essa percepção pode sofrer alguma alteração quando comparamos com o conteúdo e a forma dos making of incluídos nos filmes citados.

No making of do filme 3/2008 pode-se observar a relação que um dos alunos do grupo tem com a guerra, e assisti-lo declarando: esse cara embaixo tem que morrer, eu já tô ficando com raiva dele, e mesmo a violência autorizada nas brincadeiras que fazem diante da câmera: dá um pedala [tapa na cabeça] no Tuiu. A espontaneidade da gravação fica por conta de um narrador fora do grupo, o pai de um dos alunos - evidenciando a participação da família nas atividades escolares -, que além de filmar, emite opiniões e censuras durante o percurso. Não há a presença da mãe, são apenas homens.

A sequência dos bastidores do filme 5/2008 traz uma sequência de fotos com o objetivo de exibir momentos da produção. São as próprias alunas a estrelarem as fotos. Aqui também o sentido é tornar visível ao espectador a produção do filme. A locação é a escola, não há pais nem casa, são as mulheres. Mas é o corpo delas que está em evidência, inclusive na criação das personagens, os meninos não se expõem deste modo. 
Como declara Silva,

Para a subjetividade da menina, por exemplo, o processo de construir-se como aluna bem-sucedida é duplamente penoso: primeiro porque para submeter-se às regras da escola precisa assumir os comportamentos esperados de menina bem comportada e segundo, porque, após a adaptação, deverá sair de cena, abrindo mão do papel de boa aluna para que os meninos passem a ocupar os lugares de destaque na vida pública (SILVA et al., 1999, p. 222).

No entanto, para se contrapor a essa realidade das meninas na escola, o grupo que produziu o filme 5/2008 usou um tom agressivo, tanto na forma como no conteúdo: a produtora do filme seria FDC (foda-se), a trilha musical é em estilo hip-hop, ou seja, um movimento cultural que tem em uma de suas características a contestação, utilizam o próprio corpo como forma de expressão, recorrendo a apenas alguns apetrechos de seus bonecos para compor as personagens; o toque final também é significativo - mãaae to na Groobo, referindo-se a uma comunicação do narrador do filme com o público, nesse exercício de metalinguagem.

Apesar de as turmas nas escolas serem mistas, elas seguem critérios próprios quando se trata de formar grupos de trabalho, e o gênero pode ser um desses critérios. $\mathrm{O}$ arranjo da formação dos grupos ficou por conta dos próprios alunos. Durante a veiculação dos filmes dos alunos, não houve referência à questão de gênero. É possível ver padrões nas produções, tal como se afirmou até agora, mas este fato é dissimulado pelos demais alunos.

Charlot (1996, p. 49) afirma que

Embora o indivíduo se construa no social, ele se constrói como sujeito através de uma história, não sendo assim a simples encarnação do grupo social ao qual pertence. Assim como não é o resultado das influências do ambiente.

Mas essa realidade social, assim como o aspecto da questão de gênero, dota o sujeito de certas habilidades ou hábitos no tratamento dos assuntos escolares. Talvez a aproximação a ou o afastamento de certos temas comuns aos universos masculino e feminino seja possível. É como se o pertencimento a um grupo oferecesse aos alunos uma apropriação específica da linguagem, forma pela qual cada grupo se relaciona e decodifica o mundo. Esse domínio, porém, não é homogêneo. Antes constitui-se em "chaves de leitura do mundo: certos inventários mostram um verdadeiro trabalho de ajuste da vida afetiva e de relação à situação, aos outros e a si mesmo" (CHARLOT, 1996, p. 60).

A escola é um dos principais lugares de demarcação de gênero e sexualidade e definição ou construção das identidades coletivas e individuais quanto a esses aspectos. Portanto, é claro que isso vai ser explicitado nas escolhas estéticas, nos modos de fazer os 
trabalhos escolares, na apresentação pessoal e do material didático, tal como se verificou nos filmes dos alunos. 


\section{Capítulo 5 AVALIAÇÃO DO POSSÍVEL}

Identificar pesquisa e ensino significa preservar o rigor da produção de saber, próprio à primeira, e o compromisso de sua presença na cena social ampliada e sob controle de seus agentes, inerentes ao segundo, pensando em uma síntese desses atributos. Nesse sentido, há reciprocidade na aliança (ensino e pesquisa se iluminam, ampliam e superam simultaneamente) e garantia de que os atos de pesquisar e ensinar continuam a se questionar permanentemente em busca de novos horizontes na produção de saberes (SILVA, 2006, p. 19).

Um dos objetivos primeiros deste trabalho era utilizar a proposta para aumentar a adesão dos alunos às aulas de História. E isto foi alcançado na medida em que se estreitaram os vínculos entre professora e alunos, até mesmo nas conversas para o esclarecimento das etapas do trabalho, ou na troca informações sobre filmes e temas que assistiram em casa.

De modo geral, os alunos do $9^{-}$ano aumentaram seu repertório sobre as características e especificidades da linguagem do cinema. Trabalharam a cada bimestre com a análise de um filme, durante a qual aplicavam certas informações e procedimentos para leitura da obra. A sua participação aumentou ao longo do ano, e chegavam a identificar alguns dos elementos analíticos que eu havia apontado em outros bimestres.

Também é possível avaliar os resultados obtidos com essa pesquisa a partir da variedade do material produzido pelos alunos, tal como foi analisado no capítulo anterior. A significação que os grupos concederam às produções é variada, e não foram explicações definitivas. Antes se constituem como obra aberta à interpretação em um processo de exercício de hermenêutica.

Os alunos realizaram um exercício de seleção e interpretação das informações veiculadas em aula e também fora dela sobre o tema era Vargas. Tomaram para si uma possibilidade de leitura particular sobre o tema e esse processo assumiu contornos mais amplos devido às características da linguagem.

A utilização das técnicas do cinema foi fundamental para a composição de um discurso autoral por parte dos alunos. Nesse sentido, até mesmo nos grupos que montaram os filmes obedecendo à sequência e às informações contidas no material didático, o discurso foi alterado na narrativa que se configurou no filme, por meio da especificidade da linguagem.

Ao escolher uma linguagem para a organização do curso de História do $9^{\circ}$ ano realizei uma aposta de construção de sentido que trabalhasse nas brechas de um conjunto de regras estabelecidas pelas escolas em que trabalhava e onde a pesquisa se desenvolveu. Era 
necessário conjugar duas possibilidades: transmitir os conteúdos previstos no currículo de História, no prazo estabelecido, e também criar possibilidades de reflexão.

Conhecer uma linguagem e aprender a utilizá-la em um exercício no qual sua produção seria veiculada a um público mais amplo, tanto nas escolas A e B quanto no portal do YouTube!, proporcionou aos grupos envolvidos a oportunidade de criar sua própria narrativa. A avaliação não seria feita apenas da professora, mas também haveria uma dimensão externa, e não contou com a ponderação sobre o mérito, mas sobre a capacidade de construir uma ficção histórica compreensível ao público em geral.

Nesse processo de fabricação do filme os alunos tiveram que transportar um formato de linguagem para outro, ou seja, passar do texto do material didático, da narrativa da professora e da memória dos pais para uma produção imagética. Operar com essa adequação do conteúdo para um novo formato exige interpretação e composição de um caminho particular. Para fazer esse percurso, os alunos se valeram de recursos comuns em seu universo cultural, de modo que foi possível não somente estudar as evidências e as percepções sobre o currículo e sobre a memória do ensino de História que se consolidaram nos filmes produzidos, mas também a relação que os alunos estabelecem pessoalmente com o cinema, particularmente como consumidores. Até mesmo o efeito de achatamento da História é uma modalidade de entendimento. Ele não é desejável, mas é a explicitação de um efeito que ocorre no ensino de História.

Nesse exercício de transformar uma seleção de informações em um filme que fosse de fácil inteligibilidade para o espectador, foi curiosa a maneira pela qual os alunos escolheram aspectos da linguagem cinematográfica na composição, integrando assim um saber intuitivo sobre o cinema, o sentido de coerência e a utilização de símbolos sobre o governo de Vargas que fossem decodificáveis.

A veiculação on-line do conhecimento também possibilitou uma ampliação da comunicação da comunidade estudantil, entre as turmas de uma mesma escola e de uma escola à outra. $\mathrm{O}$ critério de expandir o número de sujeitos que poderiam conhecer o trabalho obrigou os autores de cada filme a cumprir algumas diretrizes de legitimidade. Afinal, eles produziram obras de ficção, porém a aproximação à História era um importante ponto de contato. A visão de mundo dos alunos se ampliou e ganhou uma materialidade particular com os filmes, uma vez que estes se constituíram num produto que pode ser transmitido a outros alunos.

Um ponto importante das possibilidades deste exercício foi a promoção do cinema como uma linguagem que mereça lugar nas aulas e, irreversivelmente, na escola. Para isto foi 
necessário tomá-lo em suas características constitutivas, ou seja, aproximar-se dele como documento, como linguagem propriamente dita, e também como uma modalidade narrativa. Neste ponto foi possível avaliar o domínio que os alunos adquiriram da especificidade da produção dos filmes.

Frente à cultura escolar e à tradição da memória histórica, os alunos se mostraram menos afeitos a contestar as informações contidas em seus livros didáticos na produção do enredo que escreveram. Mas foi no momento da construção do filme que alguns de seus elementos escaparam à proposta inicial de reiteração da memória histórica dominante, explicitada no roteiro. Esta percepção é relevante na medida em que a maior parte dos alunos acaba por escapar à simples reiteração pelo uso de elementos da linguagem cinematográfica e, muitas vezes, nem mesmo se dão conta dessa alteração imediata de sentido.

Decodificar os elementos mais sensíveis do cinema é algo que os alunos fazem cotidianamente, sem precisar de muitas informações, mas no projeto isto passou a ser o foco dos estudos. É certo que os alunos já possuíam, cada um à sua maneira, uma relação com a linguagem cinematográfica. O próprio didatismo da montagem fílmica já oferece aos alunos algumas informações intuitivas sobre o modo específico de operar sobre a realidade, mas esse efeito os torna apenas consumidores; no projeto eles foram chamados a serem produtores de cinema, guardadas as devidas proporções.

O trabalho trouxe contribuições no sentido de desenvolver a sensibilidade de uma cultura visual dos alunos. Isto ocorreu posto que eles vivenciaram esse universo de comunicação midiática, de comunicação da imagem, e sobre ela manifestaram uma percepção intuitiva. Esse conhecimento dialoga com um modo de ler e agir sobre a realidade, em que a sequência das imagens ganha sentido diante de uma postura ativa do espectador, o qual completa, à luz de sua experiência pessoal, a significação da mensagem. Aqui houve um exercício onde se puderam perceber esses elementos.

Esta unidade e a simultaneidade das imagens evoluindo no tempo não é produzida automaticamente. O espectador deve participar com uma associação de ideias, uma síntese de consciência e imaginação aos quais o público de cinema teve, em primeiro lugar que ser educado. Esta é a cultura visual. (BALÁZS, 2003, p. 87).

O uso da tecnologia midiática por parte dos alunos é comum nas escolas A e B onde o projeto se desenvolveu. No entanto, esse saber não é utilizado nas práticas escolares, não faz parte de um repertório a ser transmitido na instituição, tampouco é autorizado a ser um modo de instrumentalizar o conhecimento dos alunos. 
Algumas das habilidades necessárias para a montagem do filme tinham seu apoio em um conhecimento extra-escolar, mas que, ao ser autorizado a entrar nesse ambiente, foi organizado em procedimentos específicos: assistir a um filme mereceu a orientação de um roteiro, fazer um filme foi direcionado pela produção de um texto escrito e antecipadamente planejado. A relação empírica que os alunos possuíam com o cinema foi alterada e mereceu uma sistematização de informações e procedimentos de análise e composição.

Talvez este tenha sido um dos critérios avaliados pelos alunos para aderirem ao projeto. Abriu-se a possibilidade de trazerem para as aulas uma realidade que vivenciam fora delas - a comunicação por meio da Internet e o uso generalizado das modernas tecnologias digitais. A técnica e a linguagem cinematográfica como um todo não existia por si, ela era evocada para compor um discurso contendo um conjunto de informações sobre a História.

Uma das justificativas para esse limite foi a minha ação como professora, já que não passei por momentos de reflexão sobre a memória constituída sobre o ensino de História, tampouco a respeito da sua relação com a organização do currículo. Talvez minha insatisfação tenha sua origem na ignorância, mas também pode estar relacionada a uma intuição de que havia algo fora de lugar. Algumas dessas importantes investigações realizaram-se para a apreciação desse trabalho, mas há sem dúvida, um caminho longo a ser percorrido. Fica um sentimento de mal-estar, de impotência intelectual frente às armadilhas que surgiram durante o processo de investigação. Até mesmo meu envolvimento pessoal com o projeto foi relevante. No limite, a realidade da pesquisa-ação oferece um duplo objeto: o material empírico e o sujeito que o propôs. Para escapar de algumas armadilhas a orientação do professor Jaime Cordeiro foi fundamental.

Permitir que os alunos realizassem um filme sobre um tema da História, sob o signo da criação de um discurso autoral, pode gerar um efeito de relativização das informações veiculadas na escola? Ou uma descrença no material didático? Os filmes mostraram que a maior parte dos grupos confirma as informações, de modo que não há descrédito ao ensino. Antes, há um espaço em que se pretendia escapar à reprodução, comum à escola, até mesmo para evitar a simples repetição de informação - a escolha da linguagem cinematográfica foi importante, posto que permitia maior liberdade na seleção e interpretação das informações, a partir da proposição do domínio técnico da forma - por meio da construção da personagem, trilha sonora, montagem e simbolismos, entre outros.

Um dos objetivos deste trabalho era verificar o efeito da organização do curso de História do $9^{\circ}$ ano a partir de uma linguagem. Com a escolha do cinema e sua especificidade de composição - o filme feito objeto de estudo, com propostas de análise a cada bimestre - 
surgiu uma possibilidade de reconhecer algumas de suas características. Não sei se cada um dos alunos via estes momentos como uma aula de exercício, ou como um aprofundamento teórico em direção ao domínio específico de um modo de operar a comunicação. De toda forma, esse procedimento organizava o curso a partir de um padrão de atividades.

Também não ouvia reclamações dos alunos sobre esse formato de aula, nem acusações de usar a veiculação do filme para matar a aula. Convém registrar que os alunos têm abertura junto à coordenação para esse tipo de avaliação e denúncia em relação ao trabalho dos professores. A partir do avanço dos exercícios, os alunos passaram a se incomodar menos com as interferências que eram feitas em relação à forma e ao conteúdo dos filmes. Até mesmo o trabalho com trechos de obras parece ter sido aceito, ou simplesmente desistiram de me pedir para veicular a obra na íntegra.

De modo geral, o uso dos filmes como documentos a serem lidos em aula ampliou a comunicação entre os alunos e a professora; eles comentavam os títulos a que haviam assistido e trocavam impressões. Até mesmo aqueles filmes que estavam em cartaz no cinema passaram a ser comentados com regularidade. Entendo que assim a adesão às aulas melhorou, pois alguns vínculos foram estreitados.

Utilizar o cinema como elemento de construção de sentido do curso de História possibilitou a sofisticação de análise de uma modalidade discursiva em particular. Cumprimos o programa estabelecido pela escola, mas nos dedicamos também a uma outra linguagem. Os alunos participantes do projeto, tanto na atividade de análise quanto de produção de filmes tornaram-se mais atenciosos aos elementos de constituição da História. Em geral, não existem atividades de produção autoral nas aulas. O fato de participarem dos exercícios já possibilita uma reflexão sobre o tema, e também houve envolvimento com as atividades em todos os bimestres, ao longo do ano, fato que de alguma forma evidencia o interesse dos alunos no projeto.

Até mesmo quando o enredo do filme traz informações canônicas sobre a temática do governo de Getúlio Vargas, a reiteração não é simples. Ao transformar a pesquisa em uma trama e esta em um filme foi necessário escolher quais objetos seriam usados para serem os personagens, o cenário, e também os símbolos que usariam para localizar no tempo e no espaço os espectadores. Há elementos, portanto, que permitem identificar aí a construção de uma sofisticação da linguagem narrativa em relação à História, por parte dos alunos.

Foi nesta combinação que outra configuração foi possível. Em suas produções, os alunos denunciaram o lugar de onde falavam, revelando importantes elementos de sua classe 
social, bem como de sua faixa etária, realidade percebida na escolha dos bonecos que adaptaram como sujeitos na obra.

Uma modalidade historicamente mais importante e decisiva [que aquela oriunda da movimentação da câmera] foi o fato de que o cinema não mostrava outras coisas, e sim as mesmas, só que de forma diferente: no cinema, a distância permanente da obra desaparece gradualmente da consciência do espectador e, com isso, desaparece também aquela distância interior que, até agora, fazia parte da experiência da arte (BALÁZS, 2003, p. 84).

Afinal, trazer ao espectador o presidente Getúlio Vargas como um mosqueteiro, por exemplo, como foi feito num dos filmes, encerra o mesmo sentido de grande estadista que se está comunicando no material didático? Ou reiterar a sua morte ao som da trilha sonora tema de $O$ Poderoso Chefão não altera em nada a versão canônica da carta-testamento? É certo que altera, mas também não podemos ter certeza se esse procedimento é consciente para todos os alunos envolvidos na produção fílmica. No entanto, durante a veiculação para a turma a reação dos alunos, ao serem questionados sobre algumas de suas escolhas, gerou uma percepção de construção, que pode até alterar o sentido do filme.

As análises dos filmes não denunciaram que os grupos cumpriram suas atividades de modo burocrático, ou seja, não montaram suas obras sem prepará-las com atenção. É possível identificar que foram confeccionados cenários e personagens, de modo que houve dedicação aos exercícios. Até mesmo a superação de problemas técnicos confirma essa afirmação - diante das dificuldades em editar o filme, alguns grupos me procuraram, embora eu não tivesse o conhecimento suficiente para ajudá-los, e eles resolveram os problemas por conta própria, buscando apoio fora da escola. Também essa dimensão do trabalho pode ser identificada como busca pelo conhecimento.

Como professora, é possível identificar os alunos que apresentam um discurso mais crítico, no sentido de ponderar suas colocações, de apresentar outras leituras e interpretações que não aquelas presentes no material didático. No entanto, é apenas na narrativa das aulas que esses alunos podem se colocar; no registro escrito essa atitude não se sustenta, não há espaço para que isso aconteça. Nas provas que fazem, o objetivo é a conferência de um repertório mínimo sobre os processos históricos.

Até mesmo para os alunos que identifico como mais críticos, a atividade foi proveitosa. Vale lembrar que nem todos eles aderiram à proposta de fazer o filme. Mas aqueles que se envolveram puderam exercitar sua capacidade de construir um discurso autoral, e ainda comunicá-lo aos demais colegas da sala, de outras turmas do $9^{\underline{0}}$ ano e também de outra escola. $\mathrm{O}$ exercício foi, para isto, um espaço privilegiado. 
A visão de História que possuíam não se alterou simplesmente devido ao exercício, e também não se estendeu ao ensino como um todo. Antes, penso que para os alunos tratou-se de uma experiência de construção de um conhecimento, de um modo que não ocorre na escola como um todo. De modo geral, eles se adaptam bem a uma configuração de uma relação com a disciplina que passa pela ligação pessoal com o professor. Não foi uma atividade generalizante, mas de experimentação. Os resultados são pessoais, e teriam que ser avaliados caso a caso, mas esta dimensão não foi buscada desde o início do projeto. Foi possível notar, no entanto, embora isso não tenha sido feito de modo sistemático e escape, de alguma forma, dos objetivos desta pesquisa, que alguns alunos continuaram a usar essa modalidade discursiva para apresentar outros trabalhos - por exemplo, quando participaram de um concurso cultural promovido por uma editora, sem necessitar da orientação de nenhum professor. Isto pode indiciar algum grau de autonomia conquistado como resultado da sua participação neste projeto.

Cada grupo construiu um discurso sobre o governo de Getúlio Vargas e, a seu modo, selecionou elementos para dar legitimidade ao trabalho. Houve até quem desconfiasse da versão oficial de justificativa dada à morte do presidente na carta-testamento e utilizasse o documento como forma de criar outra versão para a História. Usar o conteúdo do governo Vargas para fazer um filme alterou a maneira como eles o enxergam e, portanto, a relação deles com o conhecimento histórico. Eles perceberam o que tem mais sentido e o que não tem, o que é mais representativo e o que não é; avaliaram, enfim, a coerência do ensino de História.

Uma dimensão fictícia foi usada em cada filme. Não era objetivo alterar a História, mas propor outro caminho de aproximação entre ela e os alunos, e assim foi feito. Ler as informações por outro ângulo, ou apenas confirmá-las, exigiu uma escolha pelo grupo, de sorte que os alunos também tiveram de exercitar a capacidade de lidar com os conflitos interpessoais inerentes a esse processo. Nessa ação a incapacidade de contar toda a História tornou-se perceptível.

Como um exercício, a proposta aproximou os alunos do ofício do historiador seus limites, a necessidade de coerência narrativa, todas essas ações centradas na seleção, na interpretação e na comunicação de resultados.

É possível que os alunos já detivessem a percepção aurática sobre o governo de Getúlio Vargas a partir de suas memórias escolares e extra-escolares, porém não as confirmaram quando da utilização da linguagem cinematográfica em seus trabalhos. Isso é importante, de acordo com Benjamin (1994), uma vez que um dos efeitos do processo de 
desauratização é enxergar as informações históricas sem as características de dominação que ela apresenta, é arrancá-la de seu invólucro, conduzindo a uma autonomia de pensamento. Este deve ser capaz de propiciar uma mudança social, ou seja, uma mudança da percepção que o aluno tem da realidade social. Desauratizar é revolucionário, no sentido de que transforma o trabalho do homem em pensamento alegórico e é nisto que está seu valor, na transformação da realidade, na construção de um passado com uma narrativa aberta a alternativas. A aura tem como característica a necessidade de decriptação, ou seja, o sujeito deve se aproximar de seu valor de culto. O sentido alegórico abre outra possibilidade de interpretação, a partir da relação que o sujeito estabelece entre o presente e o passado, num exercício de busca pelo entendimento do que aconteceu.

A descoberta da diferença temporal torna possível compreender como e porque o passado é construído como dimensão imaginária do presente, graças à abolição de tudo quanto no passado e no presente é dissimulado pelo exercício real da dominação: uma representação "legítima" do passado pela "legitimidade" que o presente atribui a si mesmo (CHAUÍ, 1981, p. 14).

O cinema intervém no real e produz um discurso em perspectiva, e por essa razão gera uma interpretação. É neste sentido que a produção do filme por parte dos alunos é autoral. E alguns filmes expressam de modo significativo essa realidade, uma vez que até mesmo para proporem a negatividade da informação canônica sobre o governo de Getúlio Vargas, isto é, para gerarem um contra-discurso, usaram da convenção.

$\mathrm{Na}$ experiência pedagógica, a construção da imagem trabalha por meio das convenções de um saber histórico já solidificado pela tradição da memória, mas não opera na reprodução. De modo geral, tanto por meio da utilização de símbolos, quanto de construções alegóricas, os grupos trabalharam na fratura entre o significante e o significado da História. No presente é que se dá a elaboração da História.

Na relação entre o presente e o passado ocorreu a produção ou a reprodução de signos de sua elaboração. Não há causalidade interna dessa intersecção de interesses presentes. Há uma rede de dispositivos que traçam determinado encaminhamento de leitura do passado; esse dispositivo funciona como um embaralhamento de fios. O dispositivo é uma relação de poder e esse elemento da constituição do saber histórico se evidencia nos recursos utilizados nos filmes.

O solo da criação do discurso autoral dos alunos não é inocente; esse terreno é cultural, e também responde a uma subjetivação do passado. Os filmes circulam em torno de duas possibilidades: são abertos, resultado de uma leitura particular que alude a diferentes caminhos interpretativos; ou podem trabalhar do universal para o particular de um episódio 
específico da História nacional, tal como o suicídio do presidente. Aproximar-se do cinema como linguagem, como documento que veicula uma contra-história da sociedade, abre possibilidades de entendimento da pluralidade de elementos discursivos e de sua articulação de sentido por aqueles que são os sujeitos da História. 


\section{REFERÊNCIAS}

ARQUIDIOCESE DE SÃO PAULO. Brasil: nunca mais. 33. ed. Petrópolis, RJ: Vozes, 2003 .

BALÁZS, B. A face das coisas. In: XAVIER, I. (Org.). A experiência do cinema. Rio de Janeiro: Graal, 2003. p. 87-91.

Nós estamos no filme. In: XAVIER, I. (Org.). A experiência do cinema. Rio de Janeiro: Graal, 2003. p. 84-86.

. O homem visível. In: XAVIER, I. (Org.). A experiência do cinema. Rio de Janeiro: Graal, 2003. p. 77-83.

BENJAMIN, W. A. A obra de arte na era de sua reprodutibilidade técnica (primeira versão). In: _. Magia e técnica, arte e política: ensaios sobre literatura e história da cultura. 7. ed. São Paulo: Brasiliense, 1994. p. 165-196.

O narrador: considerações sobre a obra de Nikolai Leskov. In: Magia e técnica, arte e política: ensaios sobre literatura e história da cultura. 7. ed. São Paulo: Brasiliense, 1994. p. 197-221.

Sobre o conceito da História. In: Magia e técnica, arte e política: ensaios sobre literatura e história da cultura. 7. ed. São Paulo: Brasiliense, 1994. p. 222-232.

BERNARDET, J. C. O que é cinema. 8. ed. São Paulo: Brasiliense, 1986.

BEZERRA, H. G. Ensino de História: conteúdos e conceitos básico. In: KARNAL, L. (Org.) História na sala de aula: conceitos, práticas e propostas. 3. ed. São Paulo: Contexto, 2005. p. $37-48$.

BITTENCOURT, C. M. F. Ensino de História: fundamentos e métodos. São Paulo: Cortez, 2004.

BLOCH, M. Apologia da História ou o ofício do historiador. Rio de Janeiro: Jorge Zahar, 2001. 
BOTO, C. Um credo pedagógico na democracia escolar: algum traçado do pensamento de John Dewey. Revista Eletrônica da Pontifícia Universidade Católica do Rio Grande do Sul, Porto Alegre, RS, n. 3 (60), p. 599-619, set.-dez. 2006.

BOURDIEU, P. É possível um ato desinteressado? In: Razões práticas: sobre a teoria da ação. São Paulo: Papirus, 1996. p. 137-156.

Os usos sociais da ciência por uma sociologia clínica do campo científico. São Paulo: UNESP, 2004.

A economia das trocas simbólicas. São Paulo: Perspectiva, 2005.

O poder simbólico. São Paulo: Bertrand Brasil, 2006.

Os três estados do capital cultural. In: NOGUEIRA, M. A.; CATANI, A. (Orgs.). Escritos de educação. 3. ed. Petrópolis: Vozes, 2001. p. 73-79.

BRASIL. Ministério da Educação. Secretaria de Educação Fundamental. Parâmetros curriculares nacionais: história e geografia. 2. ed. Rio de Janeiro: DP\&A, 2000.

BURKE, P. (Org.). A escrita da História: novas perspectivas. São Paulo: UNESP, 1992.

CÂNDIDO, A. Dialética da malandragem: caracterização das memórias de um sargento de milícias. Revista do Instituto de Estudos Brasileiros, São Paulo, n. 8, p. 67-89, 1970.

CAPELATO, M. H. C. et al. História e cinema dimensões históricas do audiovisual. São Paulo: Alameda, 2007.

CARRIÈRE, J. C. A linguagem secreta do cinema. Rio de Janeiro: Nova Fronteira, 2006.

CATANI, A. Escritos de educação. Petrópolis, RJ: Vozes, 2004.

CERTEAU, M. A cultura no plural. 2. ed. São Paulo: Papirus, 2005.

CHARLOT, B. Relação com o saber e com a escola entre estudantes de periferia. Caderno de Pesquisa da USP, São Paulo, n. 97, 1996. 
Da relação com o saber: elementos para uma teoria. Porto Alegre: Artmed, 2000.

(Org.). Os jovens e o saber: perspectivas mundiais. Porto Alegre: Artmed, 2001.

CHAUÍ, M. S. (Pref.). A história a contrapelo. In: DECCA, E. S. O silêncio dos vencidos. São Paulo: Brasiliense, 1981.

CHESNEAUX, J. As quadrilhas do quadripartismo histórico. In: Devemos fazer tábula rasa do passado?. São Paulo: Ática, 1995. p. 94-99.

COLI, J. O que é arte. São Paulo: Brasiliense, 2006.

CUNHA, F. L. Negócio ou ócio? O samba, a malandragem e a política trabalhista de Vargas. Disponível em: <http://www.hist.puc.cl/iaspmla.html>. Acesso em 12/02/10.

DEWEY, J. Interesse e disciplina. In: . Democracia e educação. 2. ed. São Paulo: Companhia Editora Nacional, 1952. p. 174-191.

ECO, U. Seis passos pelo bosque da ficção. São Paulo: Companhia das Letras, 2006.

FAUSTO, B. A Revolução de 1930: historiografia e história. São Paulo: Brasiliense, 1983.

FERRARA, L. A. Sala de aula: espaço de uma experiência. Revista Margem, São Paulo, n. 2, nov. 1993.

FERRETI, C. J. O filme como elemento de socialização na escola. São Paulo: Fundação para o Desenvolvimento da Educação, 1992.

FERRO, M. Cinema e História. São Paulo: Paz e Terra, 1992.

FLAMARION, C. História e Paradigmas Rivais. In: .; VAINFAS, R. Domínios da

História: ensaios de teoria e metodologia. Rio de Janeiro: Campus, 1997. p. 1-23.

FONSECA, S. G. (Org.). Currículos, saberes e culturas escolares. Campinas, SP: Alínea, 2007. 
. Caminhos da história ensinada. São Paulo: Papirus, 1993.

FOUCAULT, M. A ordem do discurso. São Paulo: Loyola, 1996.

FREIRE, L. A.; CARIBÉ, A. L. O filme em sala de aula: como usar. O Olho da História, UFBA. 2004.

GIORDANI, M. P. Brasil sempre. Porto Alegre: Tchê, 1986.

GRENN, B.; BIGUM, C. Alienígenas na sala de aula. In: SILVA, T. T. (Org.). Alienígenas na sala de aula: uma introdução aos estudos culturais em educação. Petrópolis, RJ: Vozes, 1995. p. 208-243.

KELLNER, D. Lendo imagens criticamente: em direção a uma pedagogia pós-moderna. In: SILVA, T. T. (Org.). Alienígenas na sala de aula: uma introdução aos estudos culturais em educação. Petrópolis, RJ: Vozes, 1995. p. 104-131.

KORNIS, M. A. História e cinema: um debate metodológico. Revista de Estudos Históricos, Rio de Janeiro, v. 5, n. 10, p. 237-250, 1992.

LACERDA, A. L. A "Obra Getuliana" ou como as imagens comemoram o regime. Revista Estudos Históricos, Rio de Janeiro, v. 7, n. 14, p. 241-263, 1994.

LAVILLE, C. A guerra das narrativas: debates e ilusões em torno do ensino de História. Revista Brasileira de História. São Paulo, v. 19, n. 38, p. 125-138, 1999.

LE GOFF, J. Documento/monumento. In: UNICAMP, 2003. História e Memória. Campinas, SP:

LYOTARD, J. F. A condição Pós-moderna. São Paulo: José Olimpio, 1997.

MAGALHÃES, M. S. Apontamentos para pensar o ensino de história hoje: reformas curriculares, ensino médio e formação de professores. Revista Tempo, n. 21, jul. 2006.

MARSON, A. Reflexões sobre o procedimento histórico. In: SILVA, M. (Org.). Repensando a História. Rio de Janeiro: Marco Zero, 1984. p. 37-64. 
MICELI, P. Por outras histórias do Brasil. In: PINSKY, J. (Org.). O ensino de história e a criação do fato. São Paulo: Contexto, 2006. p. 31-42.

MICELI, S. Introdução. In: BOURDIEU, P. Esboço de auto-análise. São Paulo: Companhia das Letras, 2005.

MORETIN, E. O cinema como fonte histórica na obra de Marc Ferro. In: CAPELATO, M. H. C. et al. História e cinema dimensões históricas do audiovisual. São Paulo: Alameda, 2007. p. 39-64.

MUNAKATA, K. A legislação trabalhista no Brasil. São Paulo: Brasiliense, 1984.

NAPOLITANO, M. Como usar cinema na sala de aula. São Paulo. São Paulo: Contexto, 2006.

NASCIMENTO, J. C. Cinema e ensino de história: realidade escolar, propostas e práticas na sala de aula. Revista de História e Estudos Culturais, v. 5, n. 2, 2008.

NOVA, C. O cinema e o conhecimento da História. O Olho da História, Salvador, n. 3, dez. 1996.

NÓVOA, Jorge. Apologia da relação cinema-história. O Olho da História, Salvador, n. 1, 1995.

PINSKY, J.; PINSKY, C. B. O que e como ensinar: por uma história prazerosa e consequente. In: KARNAL, L. (Org.). História na sala de aula: conceitos, práticas e propostas. São Paulo: Contexto, 2005. p. 17-36.

PUDOVKIN, V. Métodos de tratamento do material (montagem estrutural). In: XAVIER, I. (Org.). A experiência do cinema. Rio de Janeiro: Graal, 2003. p. 57-65.

O diretor e o roteiro. In: XAVIER, I. (Org.). A experiência do cinema. Rio de Janeiro: Graal, 2003. p. 71-73.

Os métodos do cinema. In: XAVIER, I. (Org.). A experiência do cinema. Rio de Janeiro: Graal, 2003. p. 66-70. 
SALIBA, E. T. A produção do conhecimento histórico e suas relações com a narrativa fílmica. 2. ed. São Paulo: Fundação para o Desenvolvimento da Educação, 1993. (Série lições com cinema, 3 ).

Experiências e representações sociais: reflexões sobre o uso e o consumo das imagens. In: BITTENCOURT, C. (Org.). O saber histórico na sala de aula. São Paulo: Contexto, 2004. p. 117-127.

As imagens canônicas e a História. In: CAPELATO, M. H. et al. História e cinema: dimensões históricas do audiovisual. São Paulo: Alameda, 2007. p. 85-96.

SEVCENKO, N. A Corrida para o século XXI no loop da montanha-russa. São Paulo: Companhia das Letras, 2001.

SILVA, A. et al. Meninas bem-comportadas, boas alunas; meninos inteligentes, indisciplinados. Cadernos de Pesquisa, Pelotas, RS, n. 107, p. 207-225, jul. 1999.

SILVA, M. História: o prazer em ensino e pesquisa. São Paulo: Editora Brasiliense, 2003.

Ensinar história no século XXI: em busca do tempo entendido. Campinas, SP: Papirus, 2006.

TRAVERSO-YÉPEZ, M. A.; PINHEIRO, V. S. Socialização de gênero e adolescência. Estudos Feministas, Florianópolis, n. 13, jan.-abr. 2005.

VAINFAS, R. Caminhos e descaminhos da História. In: CARDOSO, C. F.; VAINFAS, R. Domínios da História: ensaios de teoria e metodologia. Rio de Janeiro: Campus, 1997. p. 441-449.

VESENTINI, C. A. A teia do fato. São Paulo: Hucitec, 1997.

Escola e livro didático de História. In: SILVA, M. (Org.). Repensando a História. Rio de Janeiro: Marco Zero, 1984. p. 69-80.

VIANNA, C.; FINCO, D. Meninos e meninas na educação infantil: uma questão de gênero e poder. Cadernos Pagu, São Paulo, n. 33, p. 265-283, jul.-dez. 2009. 
TRONCA, Í. A revolução de 1930: a dominação oculta. São Paulo: Brasiliense, 1982.

XAVIER, I. Introdução. In: . O olhar e a cena: Melodrama, Hollywood, Cinema Novo, Nelson Rodrigues. São Paulo: Cosac e Naify, 2003. p. 7-28.

Sétima Arte: um culto moderno, o idealismo estético e o cinema. São Paulo: Perspectiva, 1978.

O discurso cinematográfico: a opacidade e da cena. São Paulo: Paz e Terra, 2008. 


\section{ANEXO A - FILMES PRODUZIDOS PELOS ALUNOS}

\section{A.1 Amostra de 2007}

\section{A.1.1 Filme 1/2007}

\begin{tabular}{|l|}
\hline Ano: 2007 \\
\hline Filme: 1 \\
\hline Título: Uma outra visão da História: os cacos da era Vargas \\
\hline Classificação do filme não-documentário: ficção histórica \\
\hline Tempo de Duração: 1'47” \\
\hline Técnica de Animação: sequência de desenhos criados e animados diretamente em \\
computador \\
\hline Trilha Sonora: Cantilena, das Bachianas Brasileiras no 5 , de Villa Lobos \\
\hline Grupo: misto \\
\hline $\begin{array}{l}\text { Legendas ou diálogos escritos: } \\
\text { Uma outra visão para a História } \\
\text { Os cacos da Era Vargas } \\
\text { - Que vazo } 29 \text { feio! } \\
\text { - Já sei! } \\
\text { - Que estranho! } \\
\text { Após algum tempo... } \\
\text { - Já era o vazo feio. } \\
\text { - Cuidado! } \\
\text { - Cuidado!!! } \\
\text { (continua) }\end{array}$ \\
\hline
\end{tabular}

29 Mantive a transcrição original da palavra vaso com "z" (vazo), pois foi assim que se apresentou no filme. 
(continuação)

- Cuidado o que? Que estranho...

$-\mathrm{Ai}$, doeu!

- Ah não! Isso é meu. Devolva!

- Mal educada.

- É seu? Tome então!

Era Vargas

Vazos ruins não quebram!

A menos que te quebrem junto...

Brasil chega de recolher cacos

É hora de parar de apanhar calado!

\section{Sinopse:}

O mote para o enredo nasce de uma cena cotidiana, em que uma personagem feminina anda pela sala e observa um vaso. Achando-o feio, ela tenta de diversas formas quebrálo, mas não consegue. Ela então desiste e se afasta. Após algum tempo, joga-o pela janela. Nessa ação, acerta um transeunte de chapéu que passa distraído. Diante da confusão, a personagem pede o vaso de volta e o transeunte devolve-lhe jogando na cabeça. $\mathrm{O}$ vaso em cacos funde-se com a inscrição da Era Vargas. Na sequência aparece uma mensagem: Vazos ruins não quebram! / A menos que te quebrem junto... / Brasil chega de recolher cacos / É hora de parar de apanhar calado!

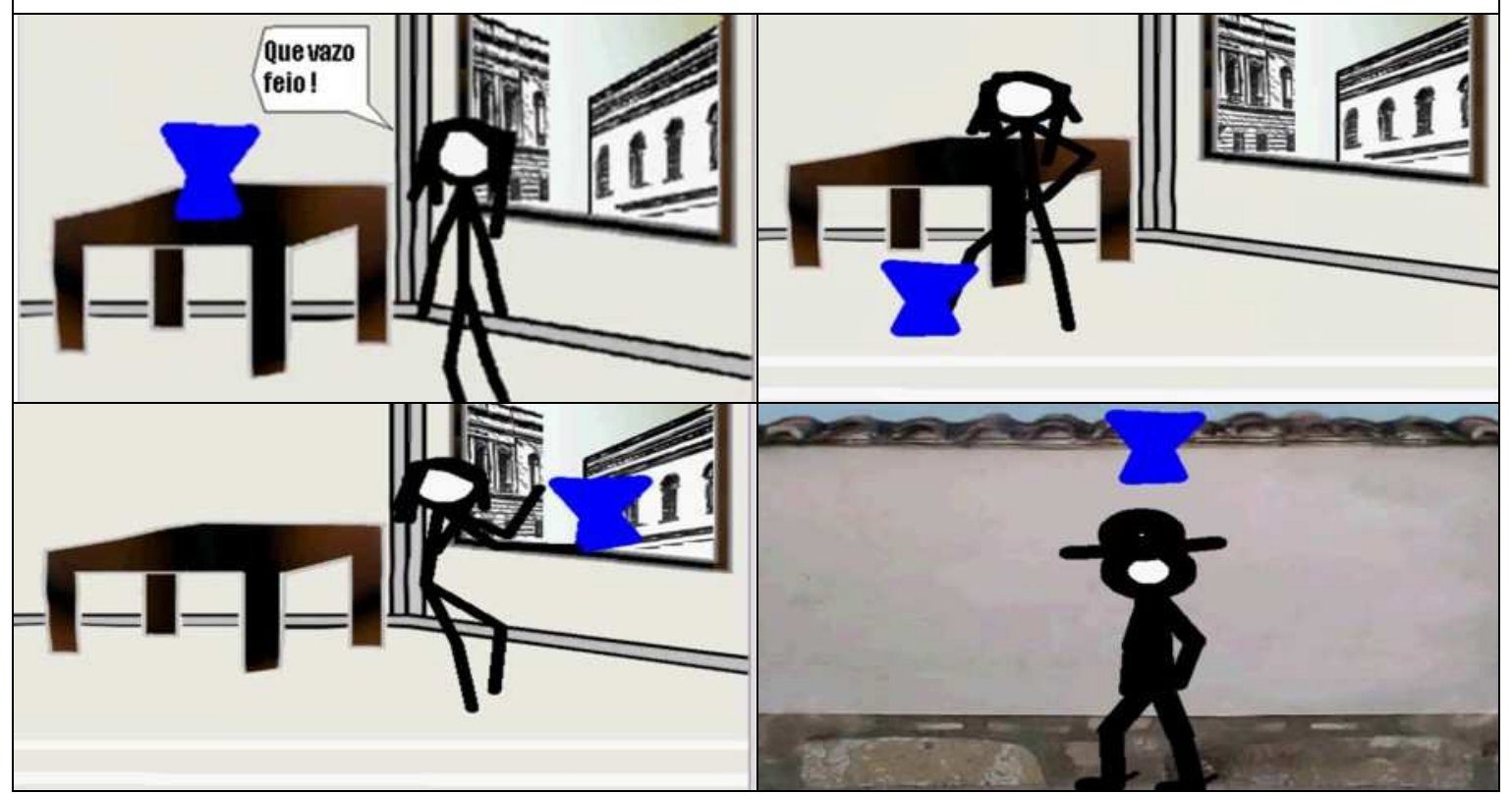

(continua) 


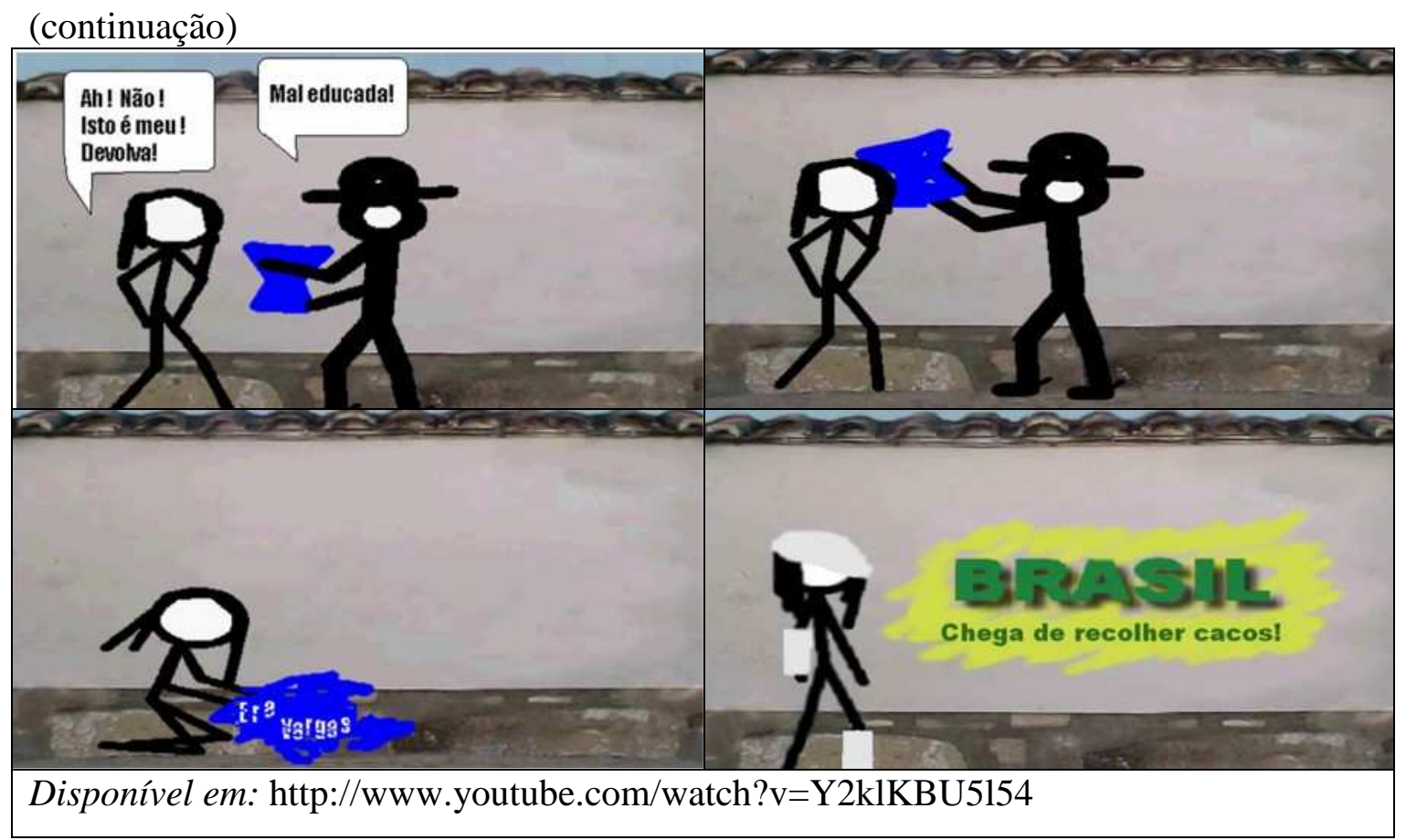




\section{A.1.2 Filme 2/2007}

\begin{tabular}{|c|}
\hline Ano: 2007 \\
\hline Filme: 2 \\
\hline Título: A era Vargas \\
\hline Classificação do filme não-documentário: Reconstrução histórica \\
\hline Tempo de Duração: 3'24'” \\
\hline $\begin{array}{l}\text { Técnica de Animação: fotos animadas no Windows MovieMaker, com personagens e } \\
\text { cenário adaptados de brinquedos }\end{array}$ \\
\hline Trilha Sonora: Faint, de Linkin' Park, e Braveheart, de Enya \\
\hline Grupo: misto \\
\hline Legendas ou diálogos escritos: \\
\hline Era uma vez uma cidadezinha feliz... \\
\hline $\begin{array}{l}\text { Um dia novas medidas governamentais transformaram o funcionamento dessa } \\
\text { cidadezinha... }\end{array}$ \\
\hline Com o salário mínimo, \\
\hline Com o seguro-desemprego \\
\hline E com outros "benefícios interesseiros" \\
\hline O novo governante dominou a cidadezinha \\
\hline Fazendo com ela o que bem desejasse \\
\hline A cidadezinha é o Brasil, \\
\hline E o governante foi Getúlio Vargas \\
\hline E o poder de evitar que algo assim aconteça novamente está nas suas mãos \\
\hline Habitante da cidadezinha... \\
\hline Fim \\
\hline Sinopse: \\
\hline $\begin{array}{l}\text { A animação se inicia em uma cidade pacata onde a paz e a ordem está garantida, } \\
\text { inicialmente, porém é quebrada quando um governante realiza um conjunto de } \\
\text { mudanças trabalhistas, como a criação do salário mínimo e o seguro-desemprego, } \\
\text { passando a dominar as pessoas e a situação. }\end{array}$ \\
\hline $\begin{array}{l}\text { A associação do governo de Getúlio Vargas ao trabalhismo reforça um dos estereótipos } \\
\text { presentes no livro didático - faço opção por avaliar e citar somente a referência do livro }\end{array}$ \\
\hline
\end{tabular}
(continua) 
(continuação)

didático utilizado nas aulas -, haja vista que preferem minimizar os efeitos da organização dos trabalhadores - a partir da Aliança Nacional Libertadora - e privilegiar uma suposta ação gratuita do presidente.

A caracterização da ação política durante o Estado Novo não merece destaque, restando na própria animação, uma versão de paz social e felicidade. Há uma percepção de manipulação das ações políticas do governo, em especial na cena em que com uma varinha mágica, as leis trabalhistas se transformam em votos. O panorama de ditadura referente ao Estado Novo não interfere no enredo da animação, que associa a postura do presidente aquele que trouxe a paz, o prejuízo é apenas à manipulação.

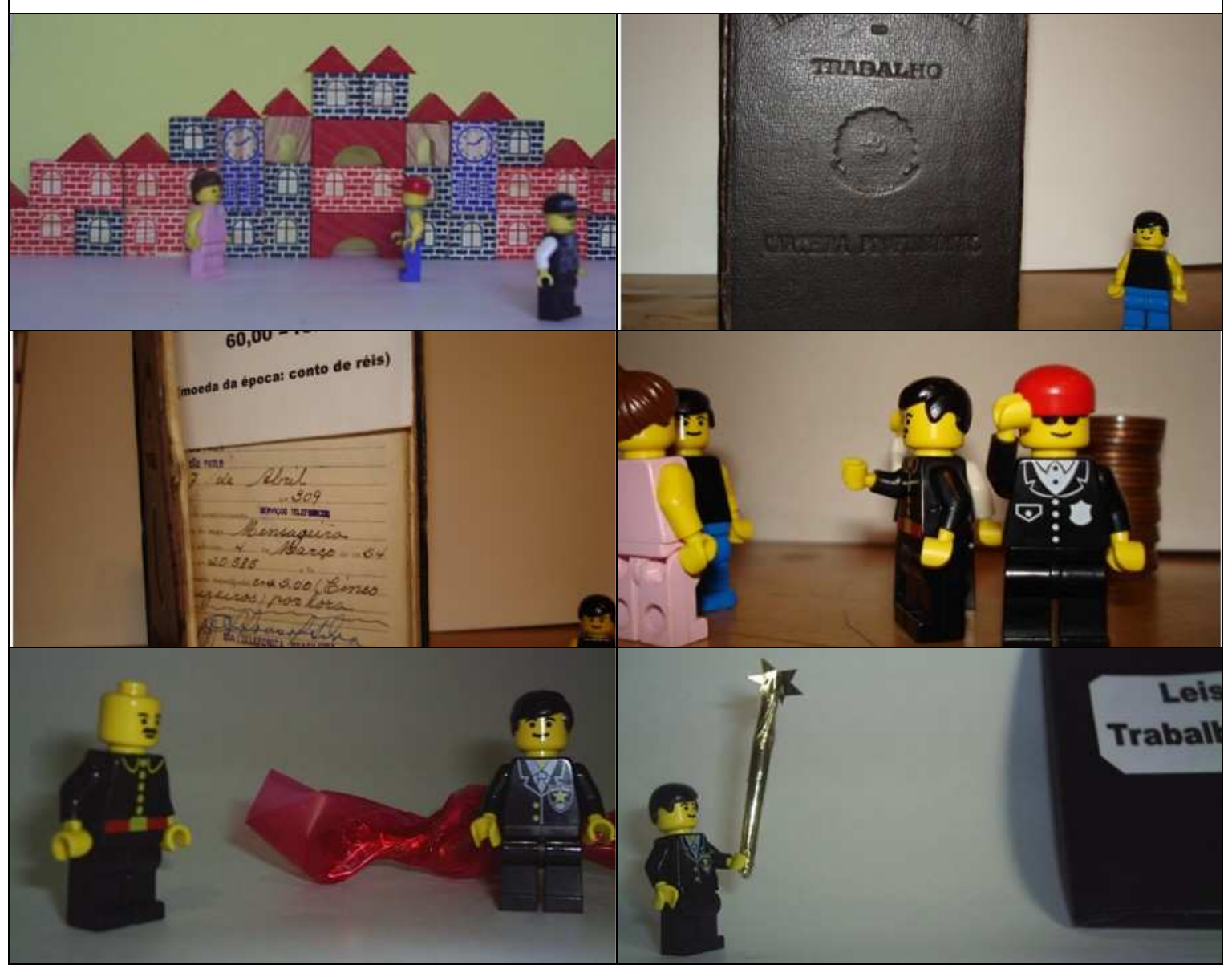

(continua) 


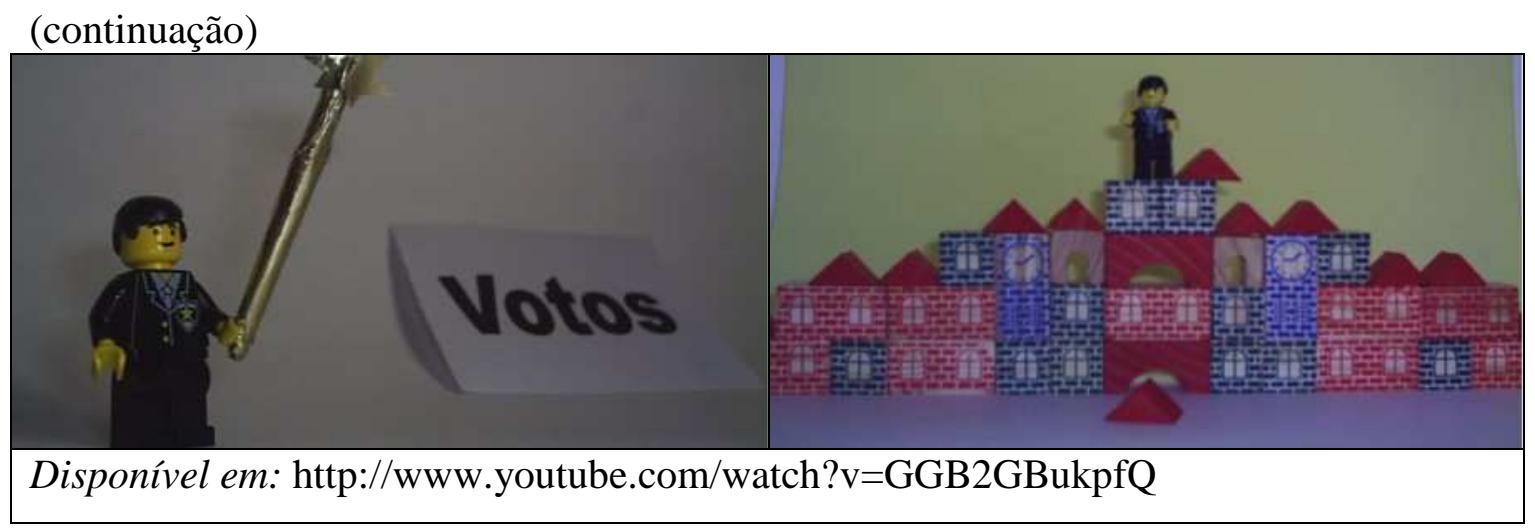




\section{A.1.2 Filme 3/2007}

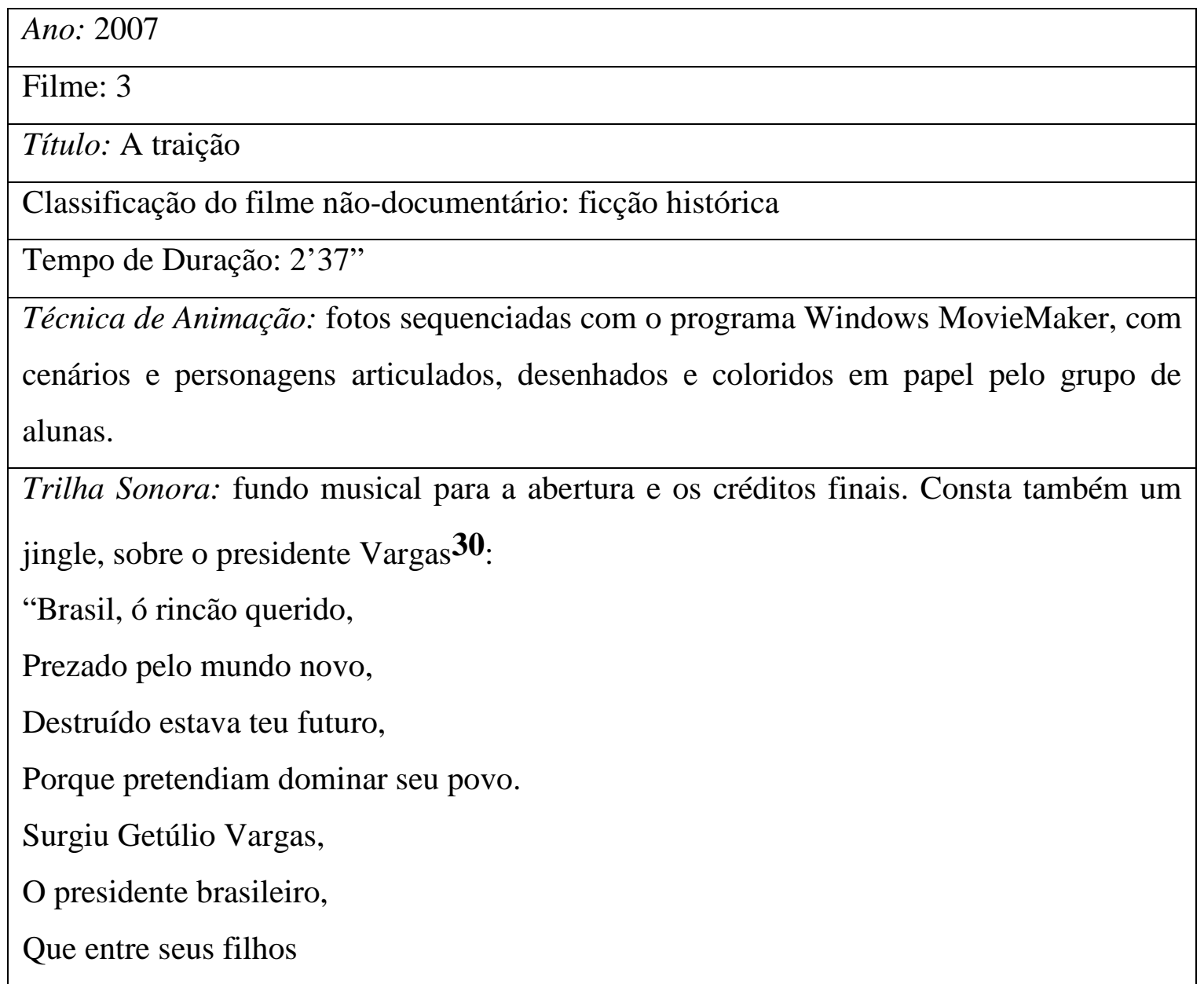

(continua)

30 Não sei exatamente onde as alunas do grupo tiveram acesso a música, porém, para conferir a letra e o áudio realizei busca na internet a partir da primeira estrofe da canção. Como resultado encontrei a letra e o áudio inteiro da canção no endereço eletrônico:

http://www.franklinmartins.com.br/som_na_caixa_gravacao.php?titulo=glorias-do-brasil\# (pesquisa realizada em 22/11/2008). 
(continuação)

Como herói foi o primeiro....31"

Grupo: feminino

Legendas ou diálogos escritos:

(Trecho de um discurso de Hitler a 200 mil jovens da juventude nazista, em 1934, seguido pela sequência abaixo)

Horas depois no escritório de Vargas, sede do Anauê...

- Hello! Would you like some Coke? (Gostaria de uma Coca?)

- Yes! (Sim!)

- Quem você prefere? (em alemão)

- Aaahh! Burn him! Turn him to hell”! (Queimem-no! Mandem-no pro inferno!)

Sinopse:

A animação apresenta uma aproximação entre o presidente Getúlio Vargas e o líder alemão Adolf Hitler e, com o imperialismo norte-americano. Contando com recurso de áudio em alemão, inglês e português, o enredo apresenta documentos históricos que são manipulados pelo grupo para compor o quadro da Traição. Até mesmo Hitler se apresenta com um chapéu nas cores e formas da bandeira dos Estados Unidos.

A aproximação entre Hitler e Vargas é sugerida aludindo-se ao apoio das massas. O auge do filme ocorre quando Vargas recebe propostas de apoio alemã e norte-americana e faz sua escolha.

(continua)

31 O jingle tocado na animação é de outubro de 1938 possui continuação, o texto completo:

"Brasil, ó rincão querido,

Prezado pelo mundo novo,

Destruído estava seu futuro,

Porque pretendiam dominar seu povo.

Surgiu Getúlio Vargas,

O presidente brasileiro,

Que entre seus filhos

Como um herói foi o primeiro.

Ainda temos na memória

Esses atos de patriotismo.

Hoje tens nome na história

Na emergência de teu negro abismo.

Porque existia em seu seio,

Entre os valores verdadeiros,

Getúlio Vargas, que veio

Mostrar ser o Brasil dos brasileiros.

Brasil, ó rincão querido ..."

Autor: Zé Pretinho e Antônio dos Santos. Intérprete: Nano Roland. Gênero: Marcha. Gravadora: Odeon. 


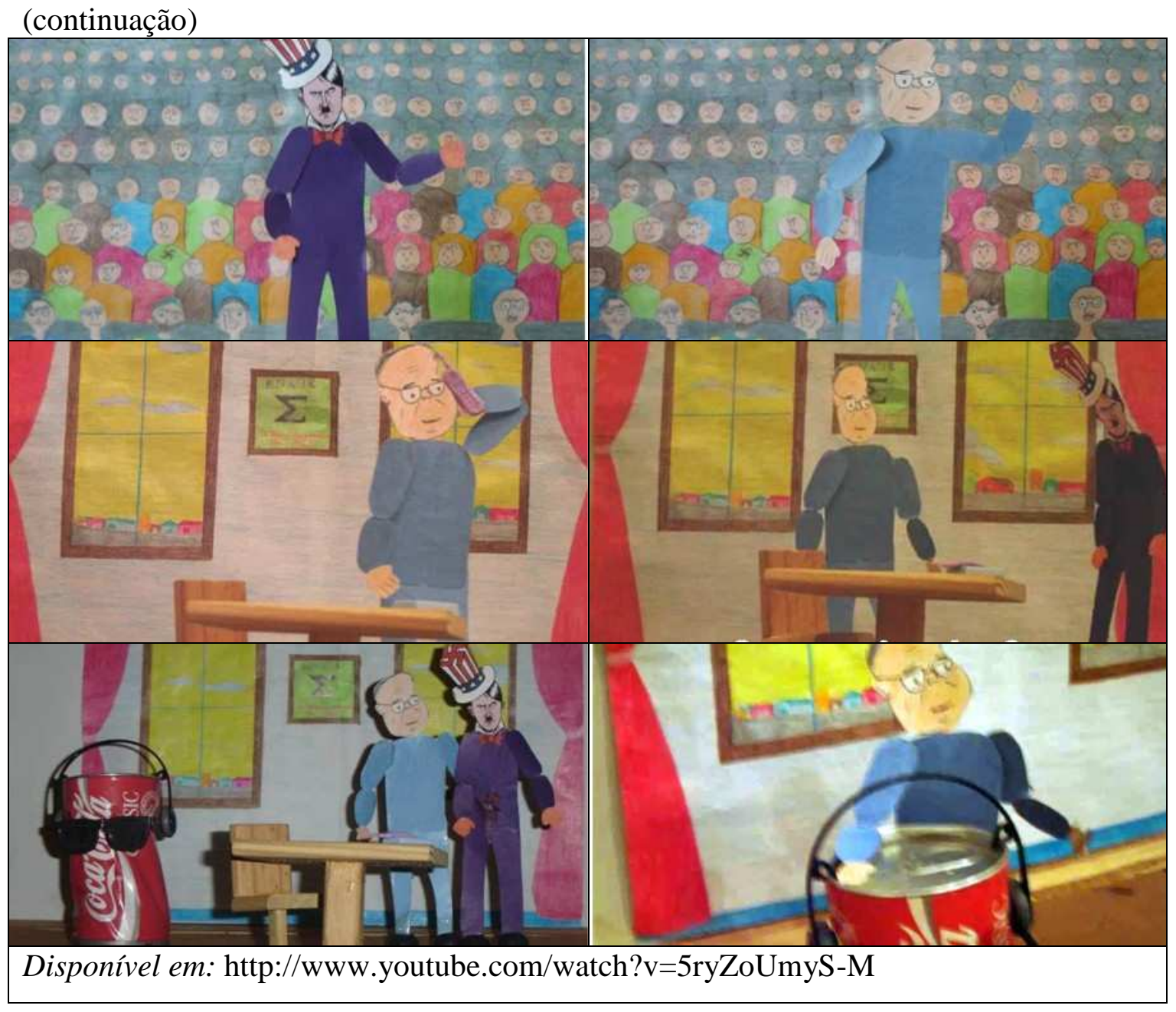




\section{A.1.2 Filme 4/2007}

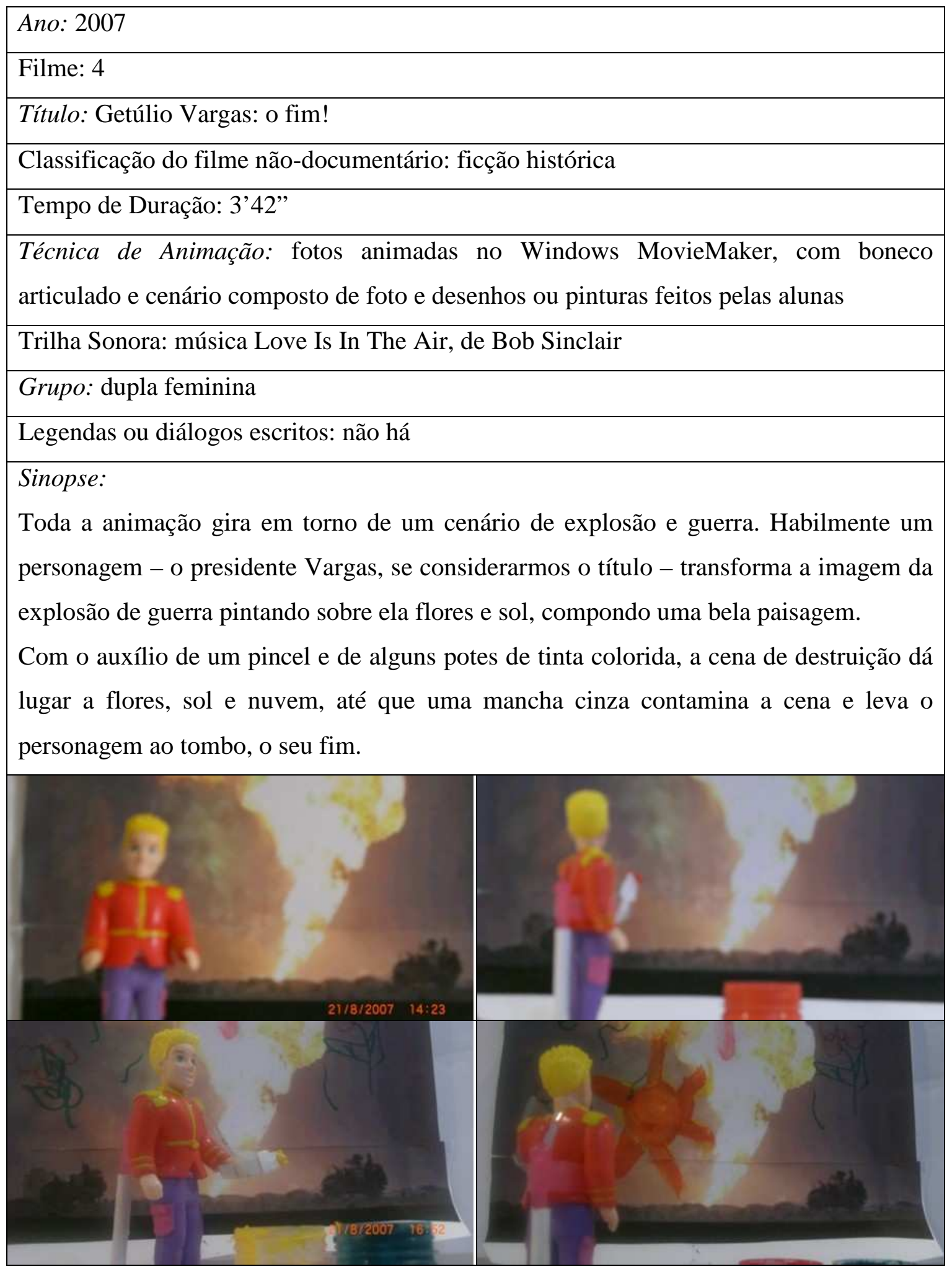

(continua) 


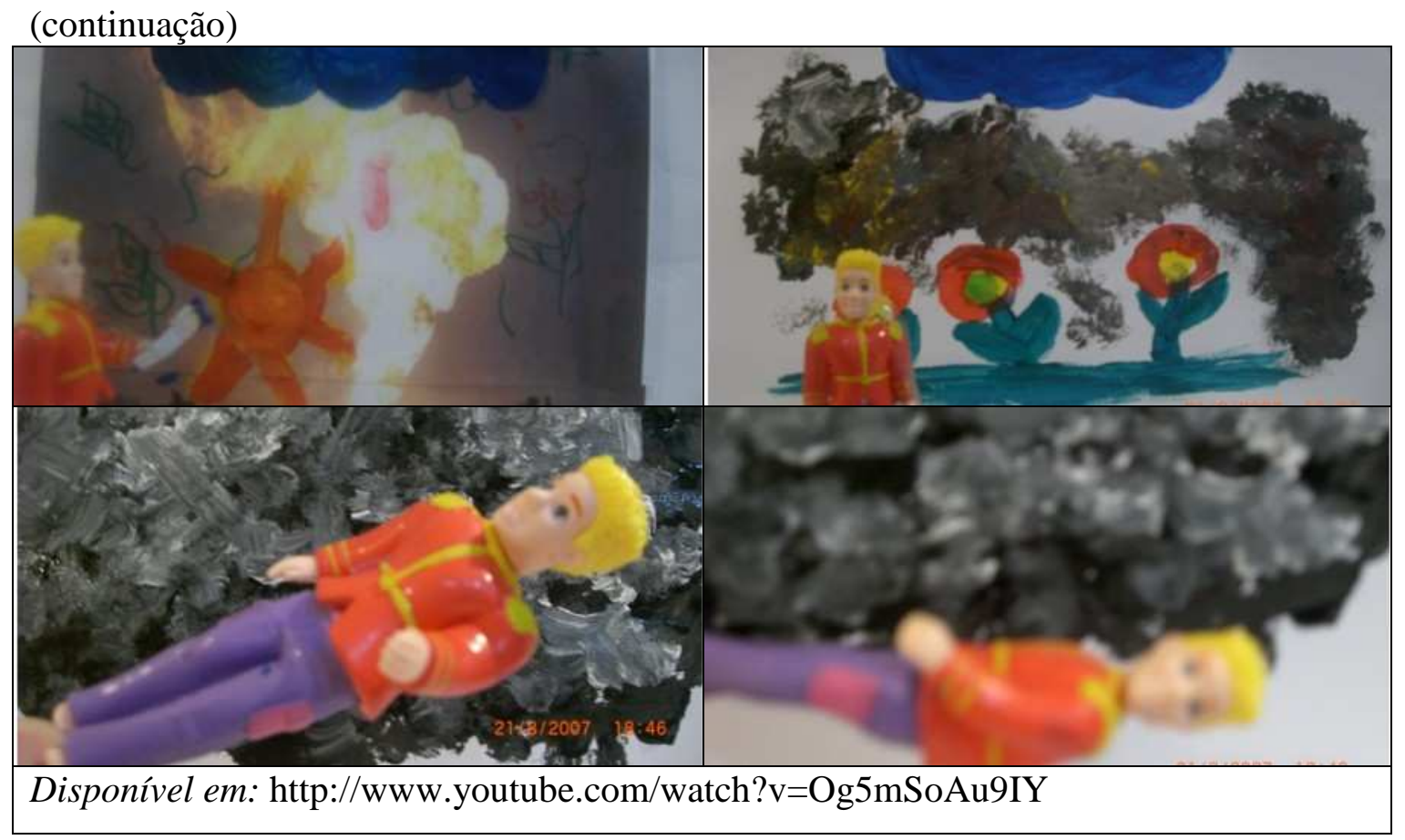




\section{A.1.2 Filme 5/2007}

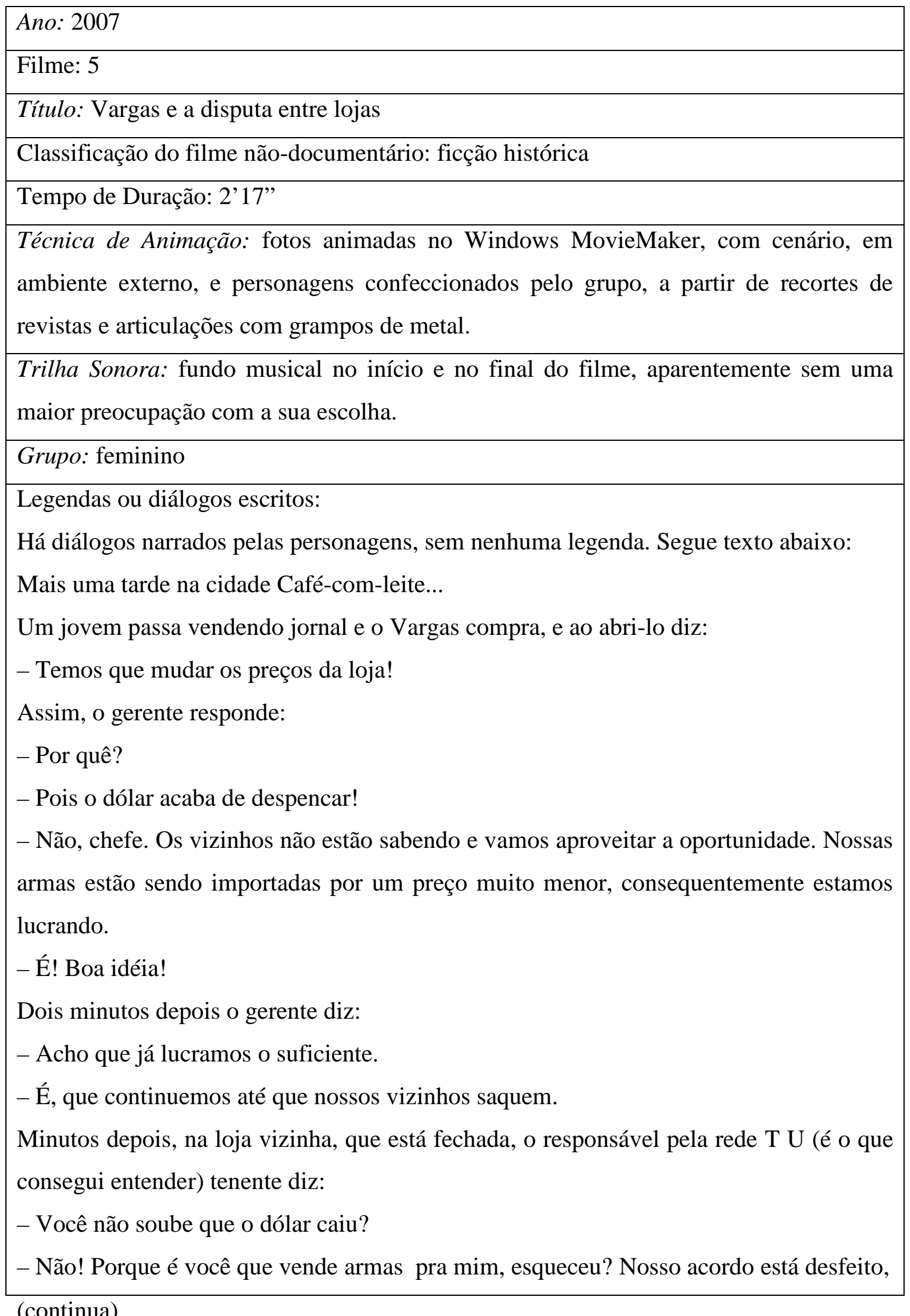


(continuação)

vou importar arma sozinho.

O responsável vai embora. Júlia Prestes fala com seu empregado:

- Acho que não vai dar. A loja está falindo. Mesmo que eu espere um país totalmente igualitário, eu sinto muito por perder a minha loja.

- Senhor, eu já comprei a placa. Gostaria que eu a pusesse?

Então pegam a placa onde está escrito Passa-se o Ponto, e a seguram no alto. Assim, Vargas percebe o movimento da loja vizinha e caminha até lá.

- O que está acontecendo?

- Perdemos de vez a loja. Gostaria de comprá-la?

- Claro! Ia ser muito bom para expandir os meus negócios!

Sinopse:

O enredo se desenvolve a partir de uma metáfora sobre duas lojas de armas. Getúlio Vargas é o dono de uma delas ${ }^{32}$ e Júlia Prestes da outra. A partir de uma queda do valor do dólar, Getúlio Vargas trama para aumentar seus lucros, enquanto a loja de Júlia Prestes vai à falência, sendo comprada por Getúlio Vargas.

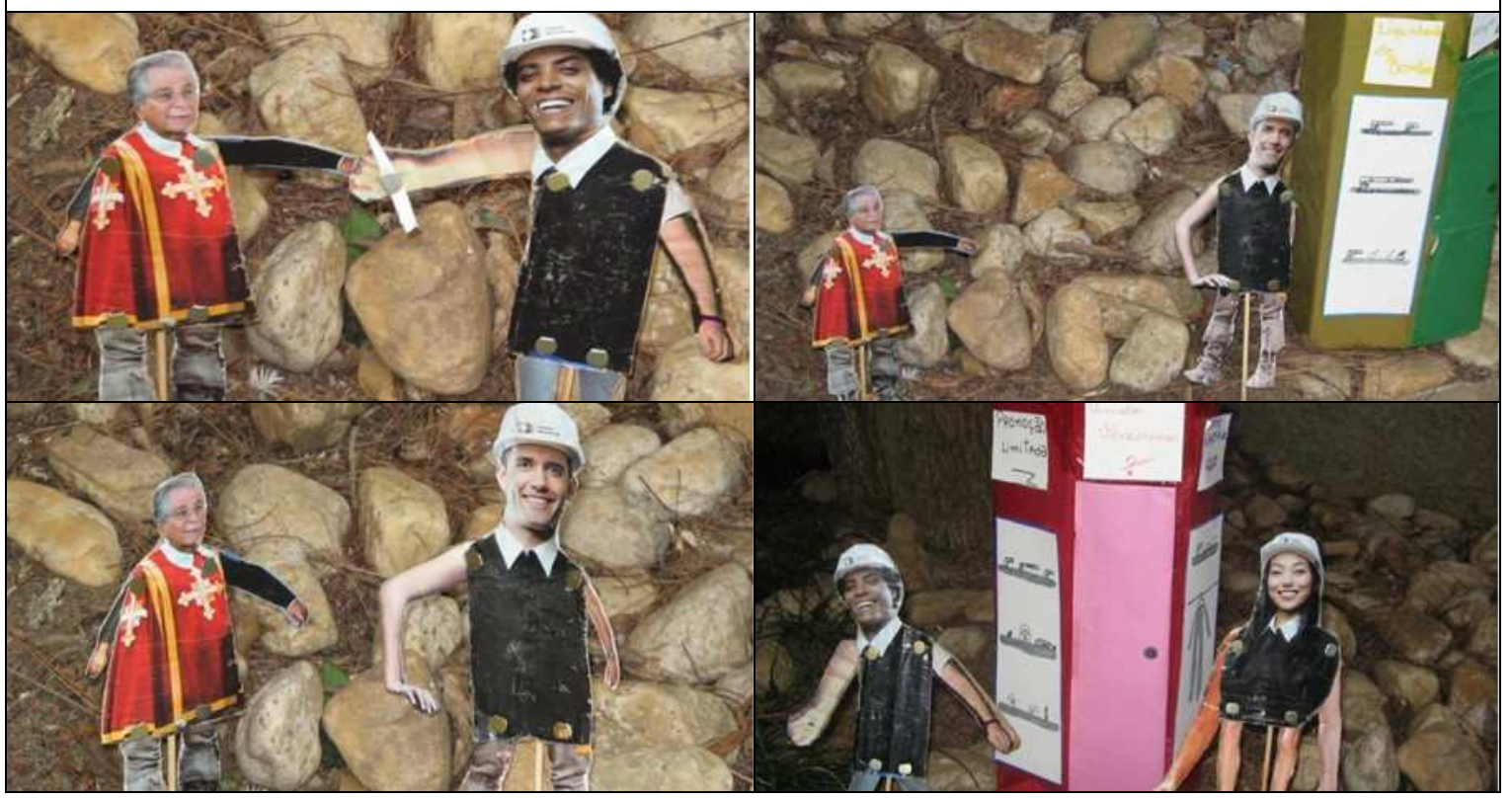

(continua)

32 A temática da República do Café-com-leite relacionada ao comércio de armas, dependente do mercado internacional, perde o sentido de fidelidade ao tema estudado em aula. Nesse sentido, irei me limitar a fazer considerações acerca dos elementos simbólicos. 


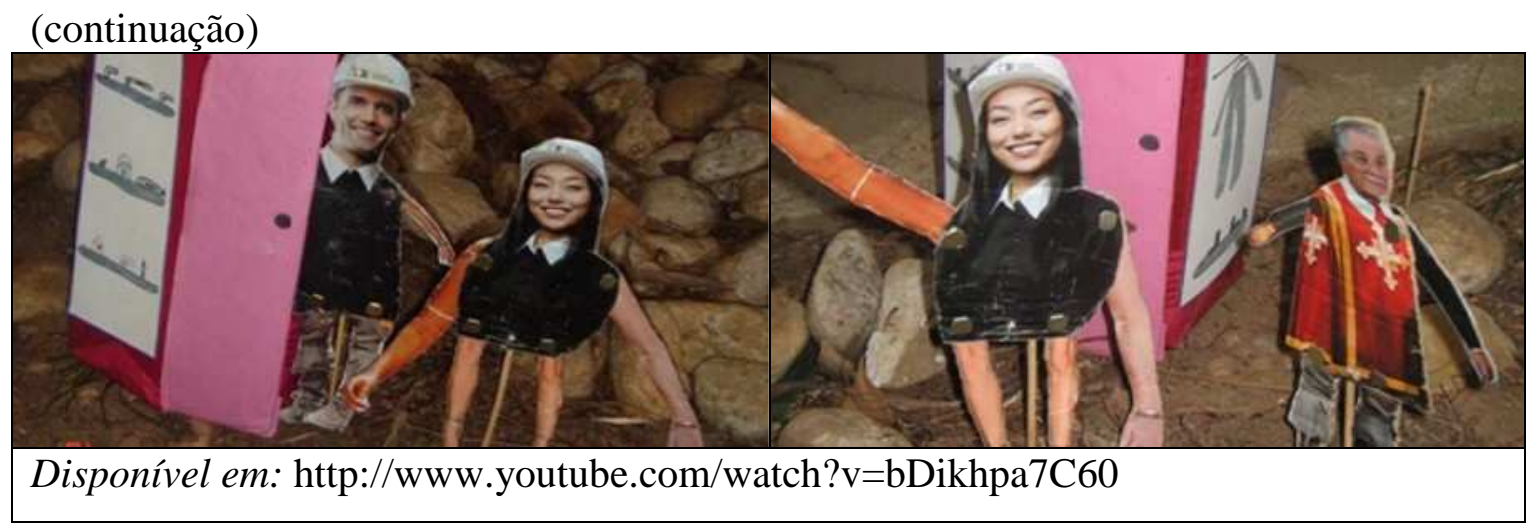




\section{A.1.2 Filme 6/2007}

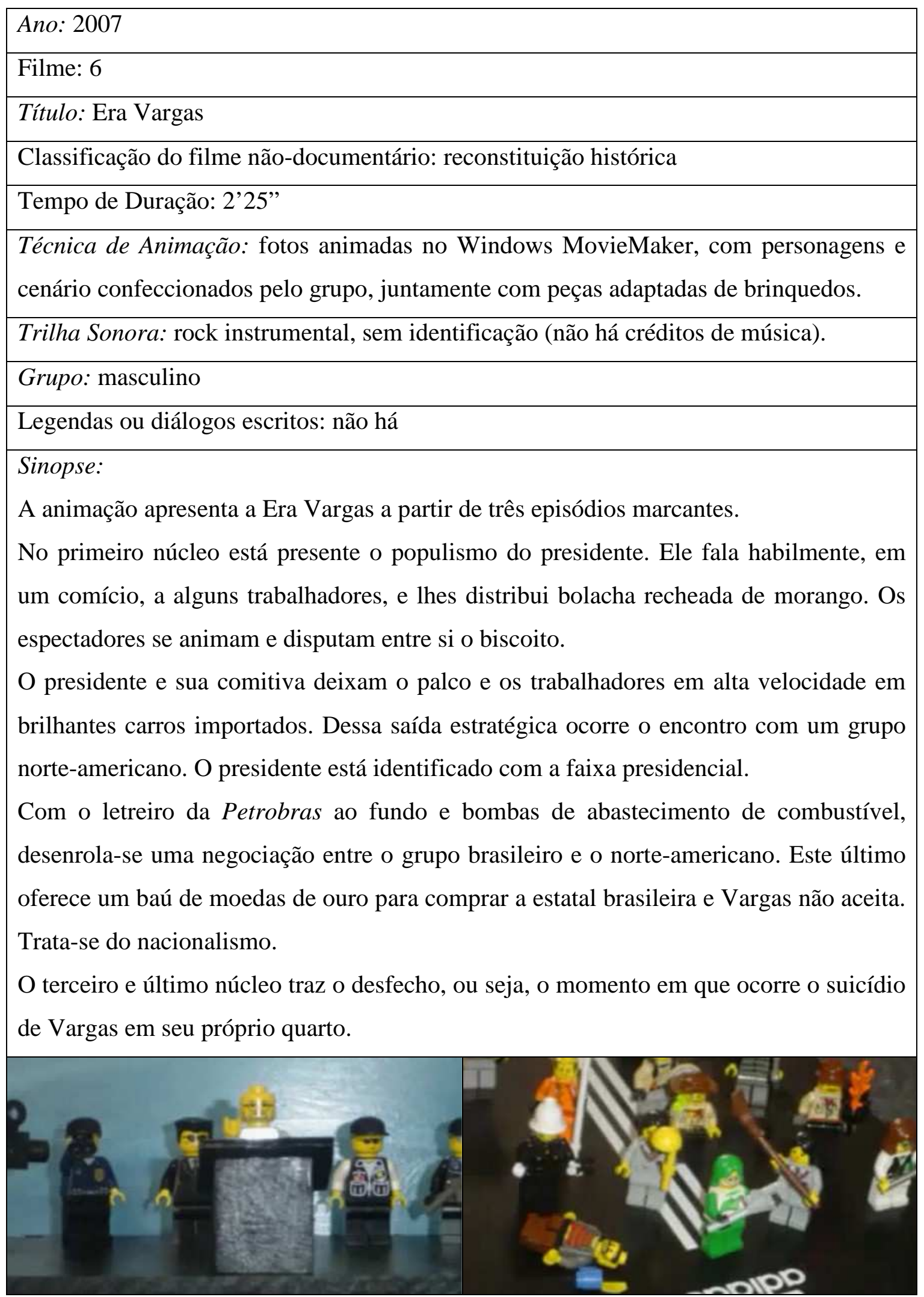

(continua) 


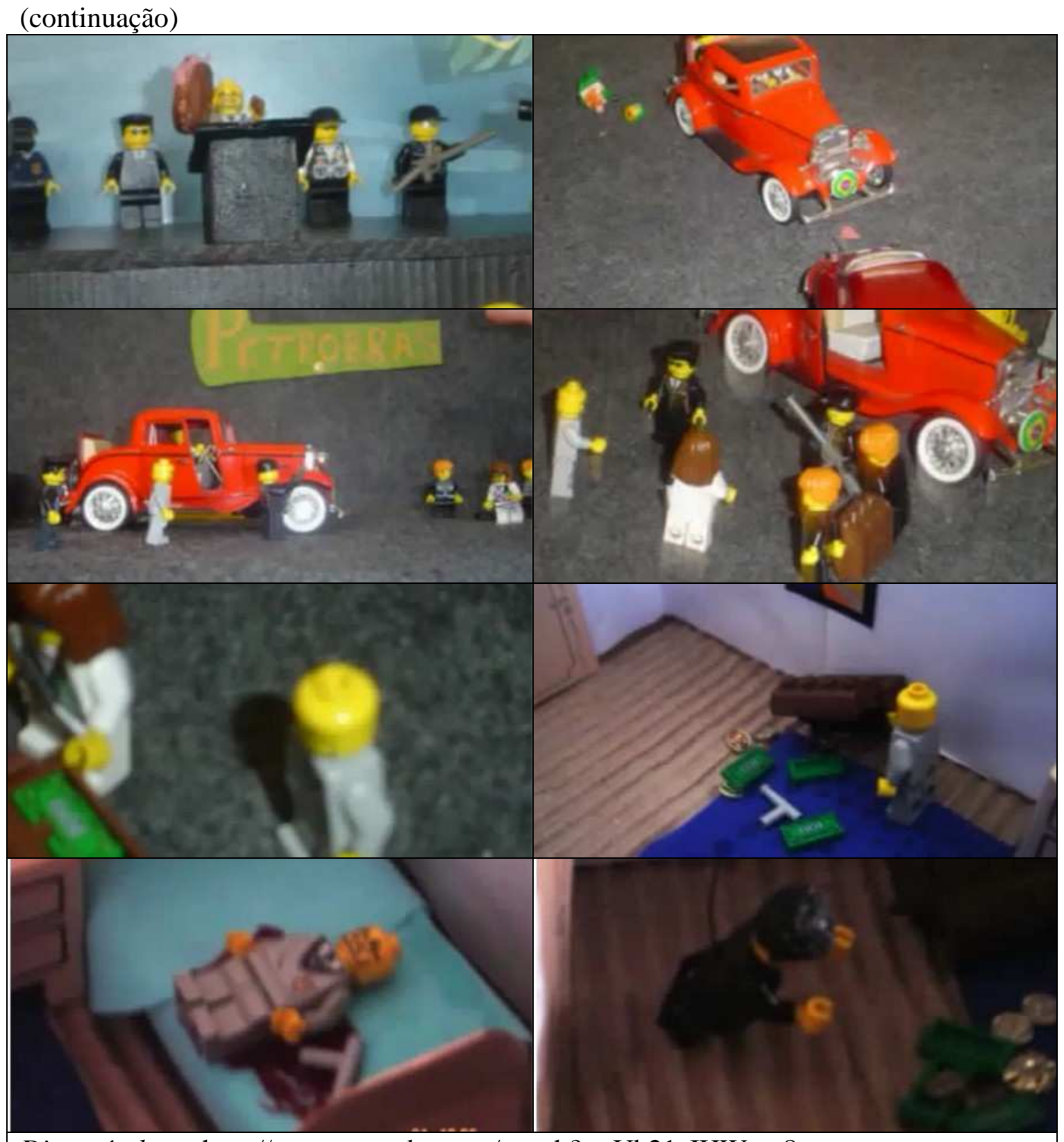

Disponível em: http://www.youtube.com/watch?v=Ub21eIHWow8 


\section{A.1.2 Filme 7/2007}

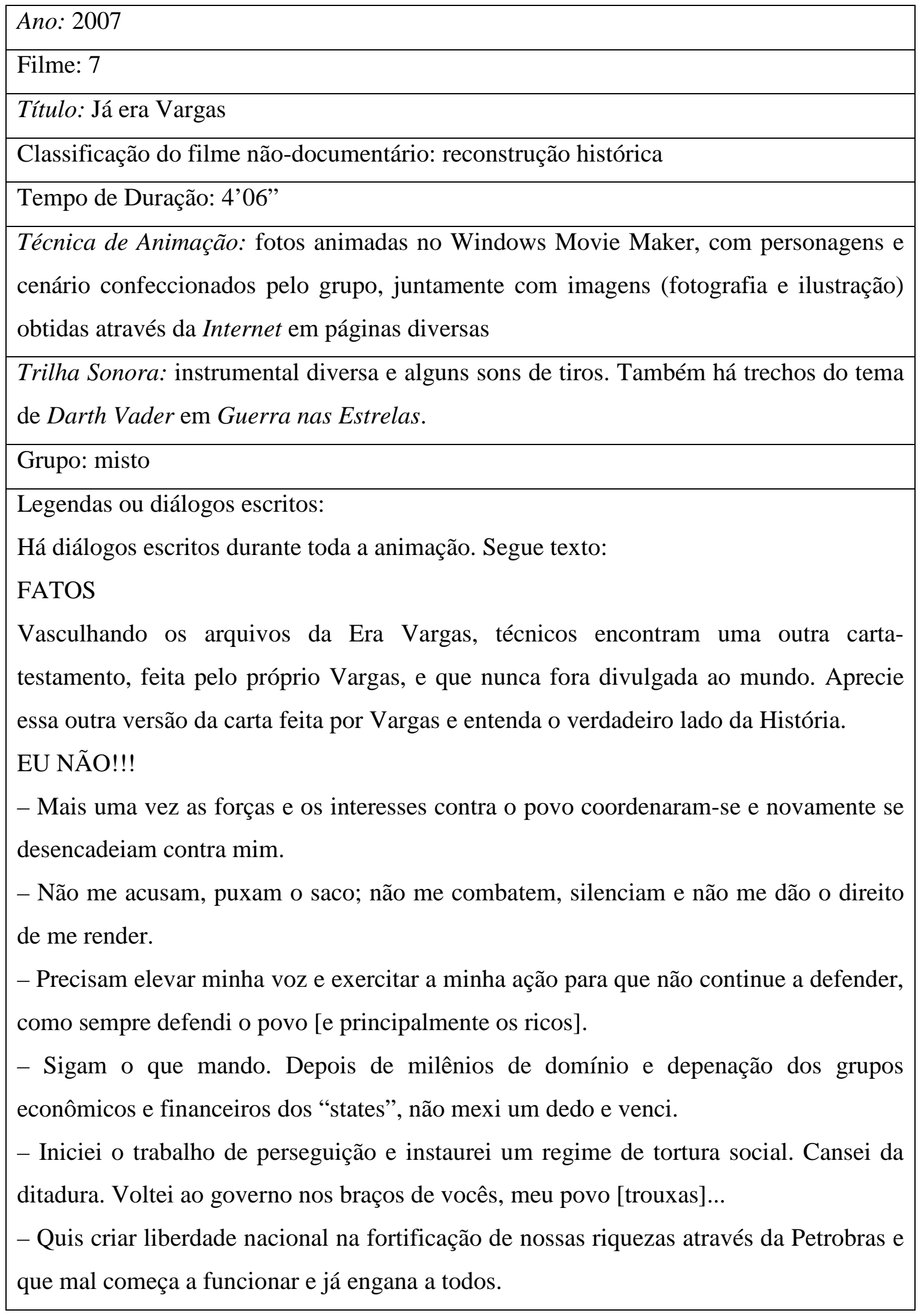

(continua) 
(continuação)

- Mas pelo amor de Deus não coloquem otários na presidência de minhas empresas, porque tive muita "aporrinhação" para criá-las.

- Os lucros das empresas estrangeiras alcançavam apenas 500\% ao ano. Nas contas recebidas existiam fraudes descobertas de somente 100 milhões de dólares por ano.

- Veio a crise do café, e acabou com nossa graça. Tentamos nos defender criando uma solução ridícula e, devido a uma violenta pressão, tivemos de desistir.

- Venho trabalhando 16 horas por mês, suportando em silêncio várias reclamações [não que eu tenha ligado] só para defender o povo, que agora está desse jeito.

- Nada mais eu posso dar, pois já dei de tudo a não ser o meu sangue. Se as aves de rapina querem o sangue de alguém, que vá procurar o povo, porque "to" nem aí.

- Escolho esse meio de estar sempre convosco. Quando vos humilhardes, verão só um pé na areia [com certeza não será o meu].

- Quando a fome bater à vossa porta lembrem-se de que sou o presidente e não o padeiro. Quando vos desprezarem, desprezem-nos de volta. Meu sacrifício será minha última tentativa de enganá-los e de me deixar como herói.

- Cada litro do meu sangue servirá para alimentar o futuro que eu vos proporcionei [coitados]. E ao ódio respondo com o dedão!!!

- E aos que pensam que me derrotaram digo que estavam certos. Era feitor do povo, e hoje, infelizmente me livro desse hobby.

- Mas esse povo do qual fui feitor não mais será escravo de ninguém. Meu sacrifício será inútil, e meu sangue servirá para manchar minha cama.

- Tenho lutado de peito aberto [literalmente]. Os ódios, as infâmias e as calúnias não abateram o meu ânimo, mas sim, a mim por inteiro.

- Minha morte será a única coisa boa que eu vos dei. Nada receio!!

- Serenamente dou o primeiro passo no caminho da eternidade e saio da vida para entrar na História.

- Mesmo que minha imagem não fique boa!!

No quarto de Vargas, no Hotel...

- Bom com toda aquela besteira que falei hoje já deixei o povo com bastante remorso e já posso me livrar de todo esse inferno.

- MORRO MAS NÃO SOU PEGO!

- Ahn?? O que aconteceu?!?!

(continua) 
(continuação)

- Quem apagou as luzes???

- Hohohoho!!!!!!! Seu desgraçado! Não ME ajudou na SS né?! Agora eu vim do inferno te buscar!!!!

(som de tiros)

- Droga ERREI!!!!!!!

- Droga errei DE NOVO!!!!!

(Passam-se os créditos finais)

- Agora eu não erro MAIS!!

Sinopse:

O filme desenvolve-se a partir de uma espécie de paródia da chamada carta-testamento atribuída ao presidente Vargas.

O presidente é caracterizado como um Banana de Pijama e confessa ao espectador suas dores, seus sonhos e sua estratégia para virar herói, ou seja, morrer e não ser punido. Frente a esse caminho para a injustiça, o líder brasileiro tem seus planos internacionalizados com a chegada noturna de Hitler. Ele, diretamente do inferno, volta para acertar as contas com Vargas, tido aqui como traidor dos princípios nazistas. A comunicação com o mundo dos mortos não é muito eficiente e apenas o terceiro tiro atinge o alvo, após ter sido acompanhado de uma promessa: Agora não erro MAIS!!!

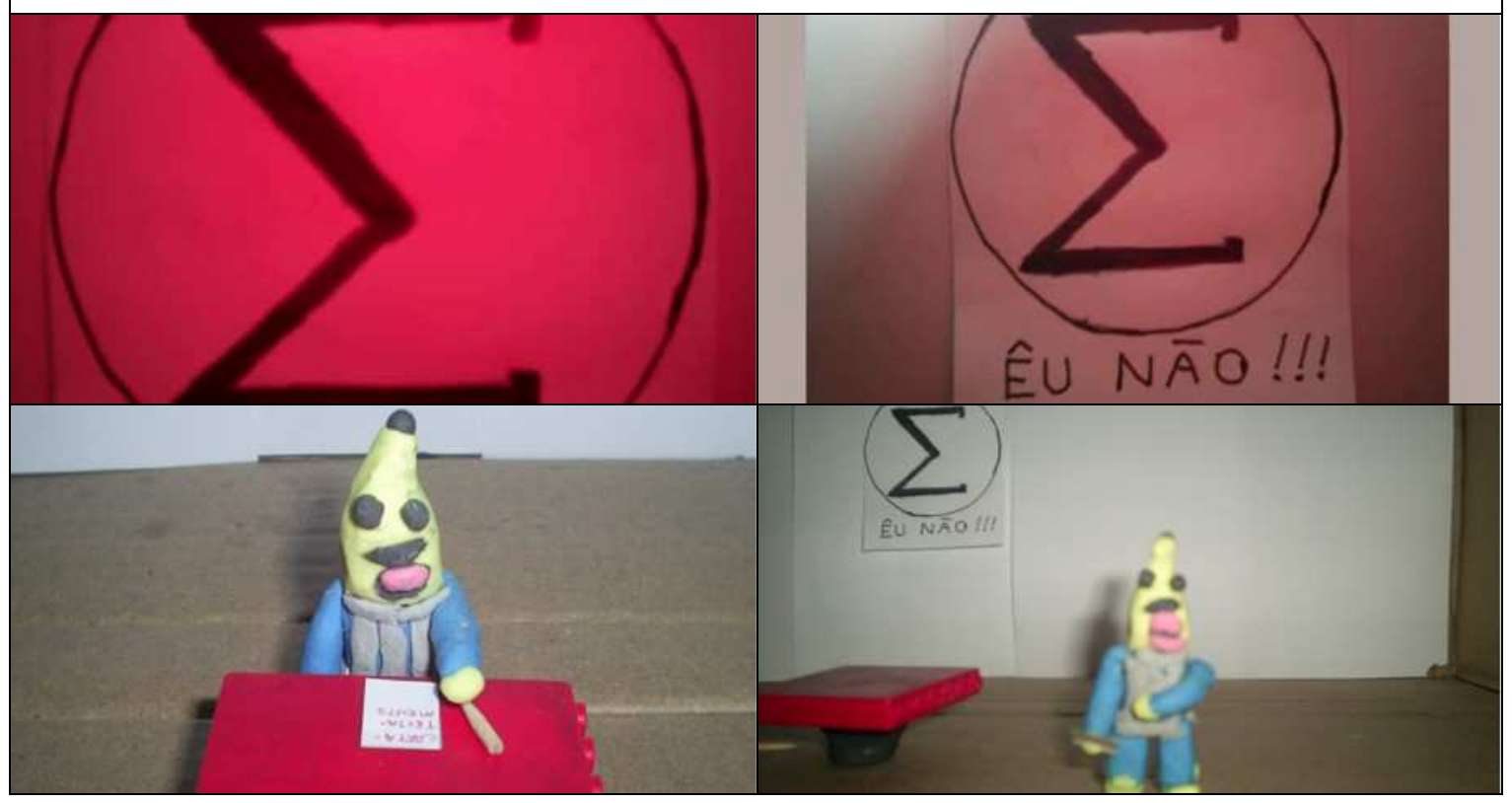

(continua) 


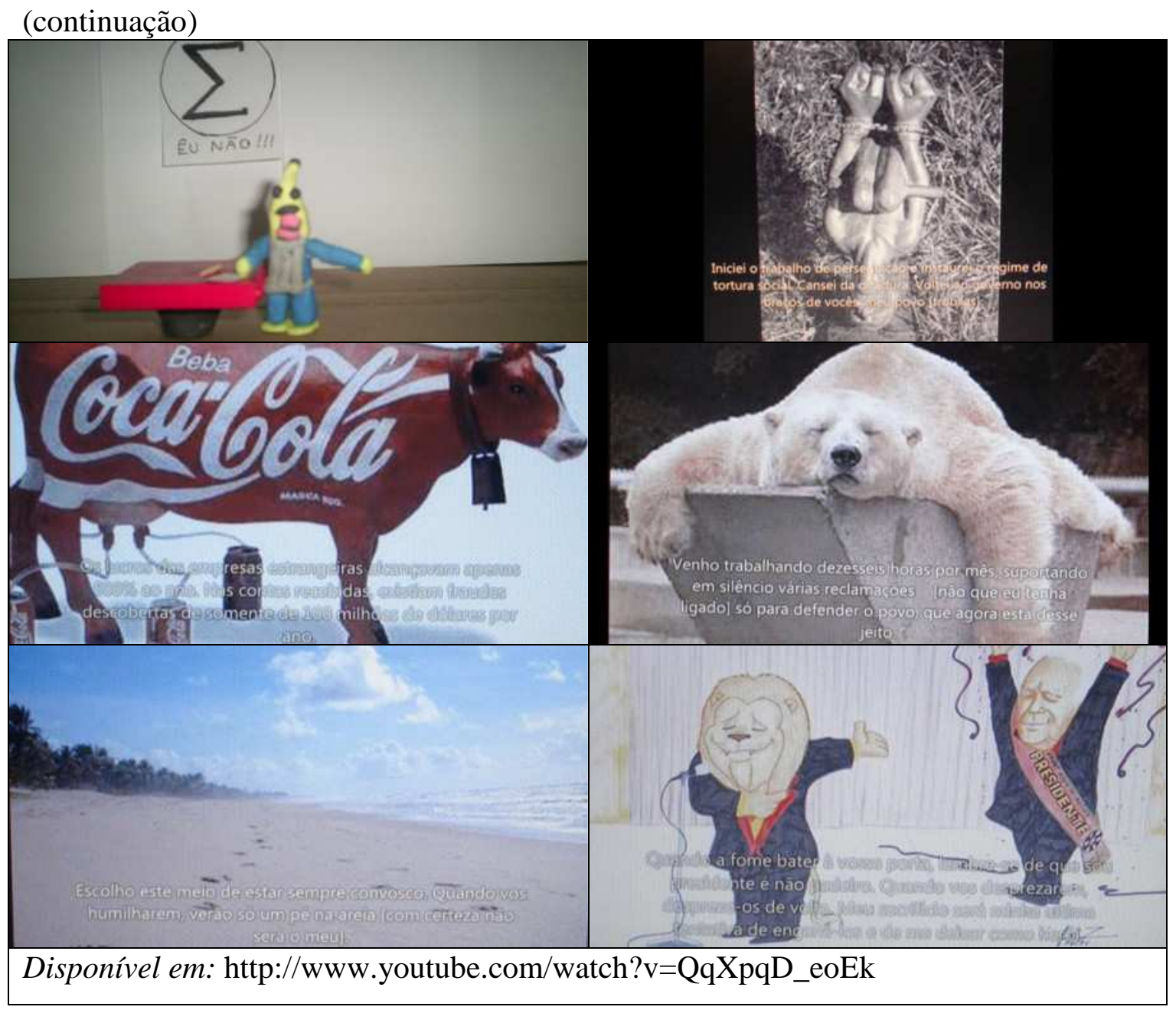




\section{A.2 Amostra de 2008}

\section{A.2.1 Filme 1/2008}

\begin{tabular}{|c|}
\hline \\
\hline Filme: 1 \\
\hline Título: O vira-casaca \\
\hline Classificação do filme não-documentário: ficção histórica \\
\hline Tempo de Duração: 5’25" \\
\hline $\begin{array}{l}\text { Técnica de Animação: Cenários e personagens construídos a partir de objetos } \\
\text { adaptados. Confecção de alguns adereços em papel para a ambientação. Fotos } \\
\text { sequenciadas no Windows MovieMaker. Finalização com créditos e sonorização. }\end{array}$ \\
\hline $\begin{array}{l}\text { Trilha Sonora: Duas músicas - no estilo rock - não identificadas, sendo uma } \\
\text { instrumental e a outra cantada. }\end{array}$ \\
\hline Grupo: feminino \\
\hline $\begin{array}{l}\text { Legendas ou diálogos escritos: Há dois trechos de discursos de Adolf Hitler em alemão, } \\
\text { mas não foi possível transcrevê-los nem tampouco traduzi-los. }\end{array}$ \\
\hline $\begin{array}{l}\text { Sinopse: } \\
\text { A personagem clássica do Ursinho Pooh é transformada no presidente Getúlio Vargas } \\
\text { para o desenvolvimento do filme. Logo no início, o toque de um telefone o faz sair de } \\
\text { sua cama e, ao atender, é possível ouvir Adolf Hitler, com voz forte, dando ordens. } \\
\text { Após desligar o telefone, entra em cena outro personagem - Ronald McDonald, } \\
\text { representante emblemático do estilo de vida norte-americano. Ele se aproxima do } \\
\text { presidente e usa toda sua capacidade de intimidação frente ao brasileiro, para afastá-lo } \\
\text { dos princípios nazi-fascistas. Violência física e suborno fazem o presidente aderir ao } \\
\text { capitalismo estadunidense, porém também permanece atento ao nazismo. }\end{array}$ \\
\hline
\end{tabular}
(continua) 


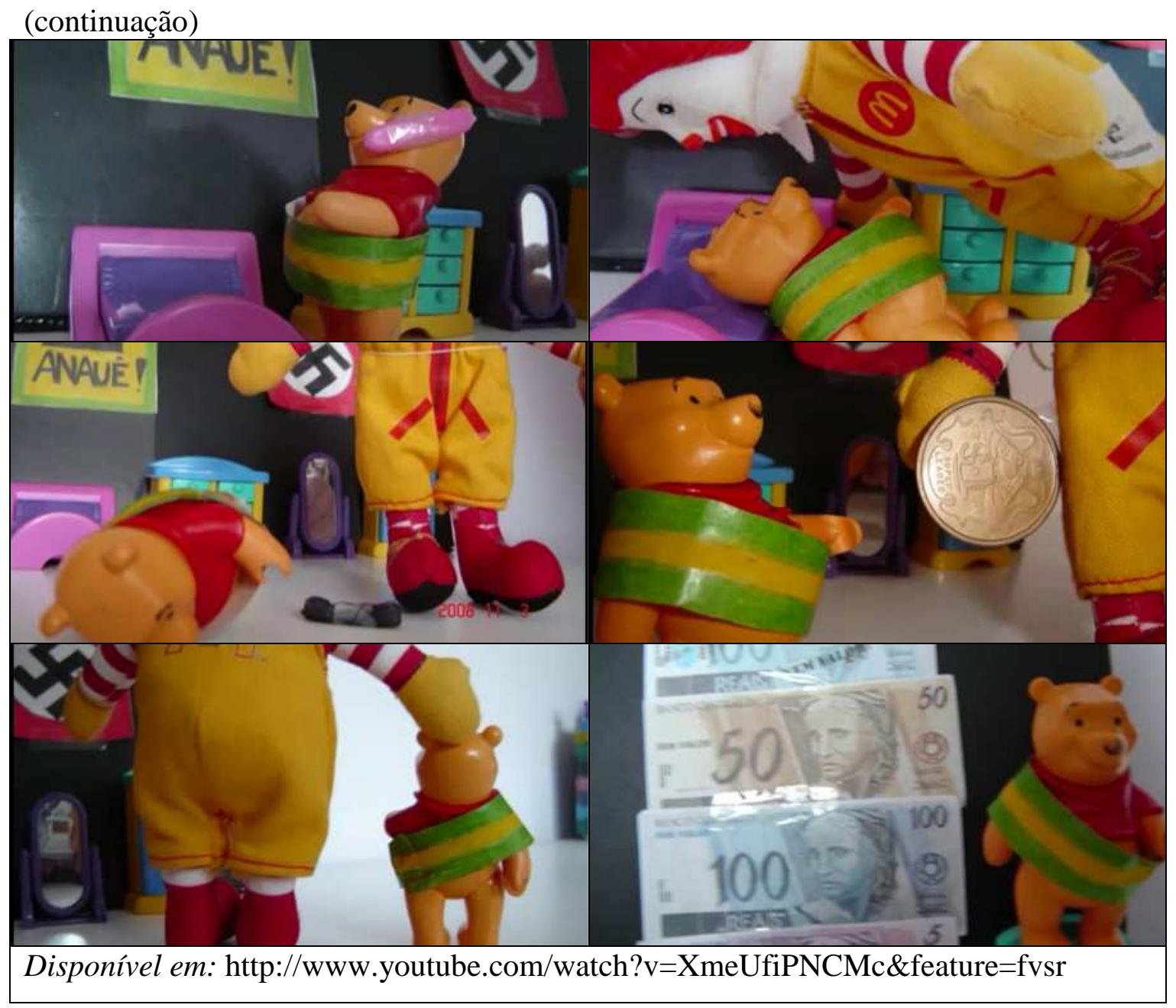




\section{A.2.2 Filme 2/2008}

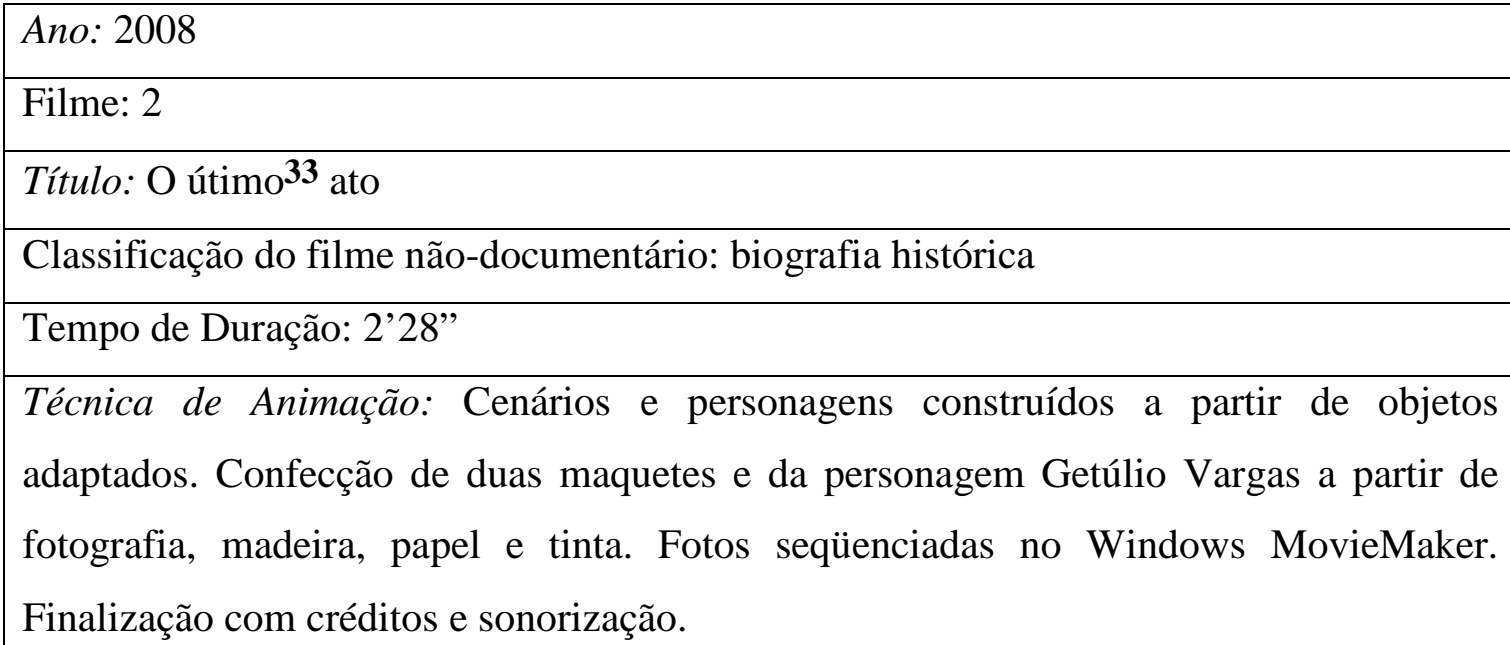

Trilha Sonora: Música-tema da Pantera Cor-de-Rosa, de Henry Mancini, Sociedade Alternativa de Raul Seixas e W/Brasil de Jorge Benjor.

Grupo: misto

Legendas ou diálogos escritos:

O último ato

Um filme de (aparece o nome dos integrantes do grupo)

Vargas planeja algo...

O que será (ao fundo da legenda, fora de foco é possível ler: Rua Toneleiros)

Lacerda, você se meteu com a pessoa errada (sonoplastia de tiros).

Lacerda levou um tiro no pé, e não vai deixar isso barato.

Vargas tentou se matar, esse cara não presta (como manchete de um jornal, e neste é possível ler ainda: Nota publicada por Lacerda).

E Vargas se mata... Fim!

Sinopse:

Sob o título Último Ato inicia-se a narrativa da animação em que os momentos finais da vida pública do presidente Getúlio Vargas são representados. A referência ao atentado da rua Toneleiros, em que um dos opositores políticos do presidente, Carlos Lacerda, é baleado, surge como justificativa para o suicídio do líder brasileiro. Sua morte é o ponto alto do filme. $\mathrm{O}$ fatídico momento ganha um tom grandiloquente, diante de um disparo (continua)

33 É certo que a grafia que o grupo pretendia era último, e não útimo, nesse sentido, o título foi mantido tal como no original, mas as análises foram realizadas no sentido de último. 
(continuação)

de canhão e do destaque à trajetória da bala que derruba Vargas em um golpe fatal.

Após a animação, o espectador pode assistir também a algumas cenas extras, com fotos que não entraram na montagem final, bem como a algumas experimentações de enredo que os autores abandonaram.

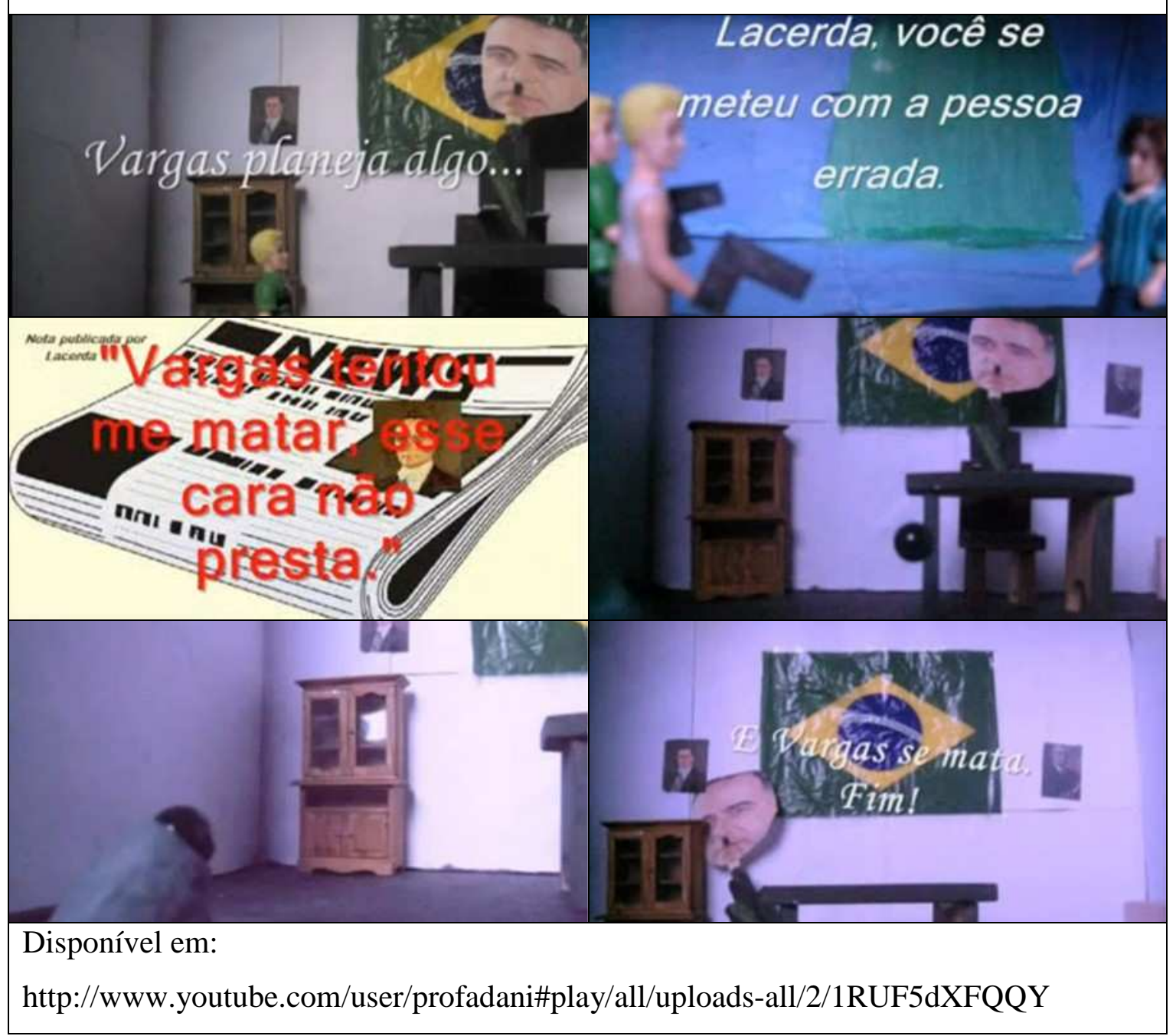




\section{A.2.3 Filme 3/2008}

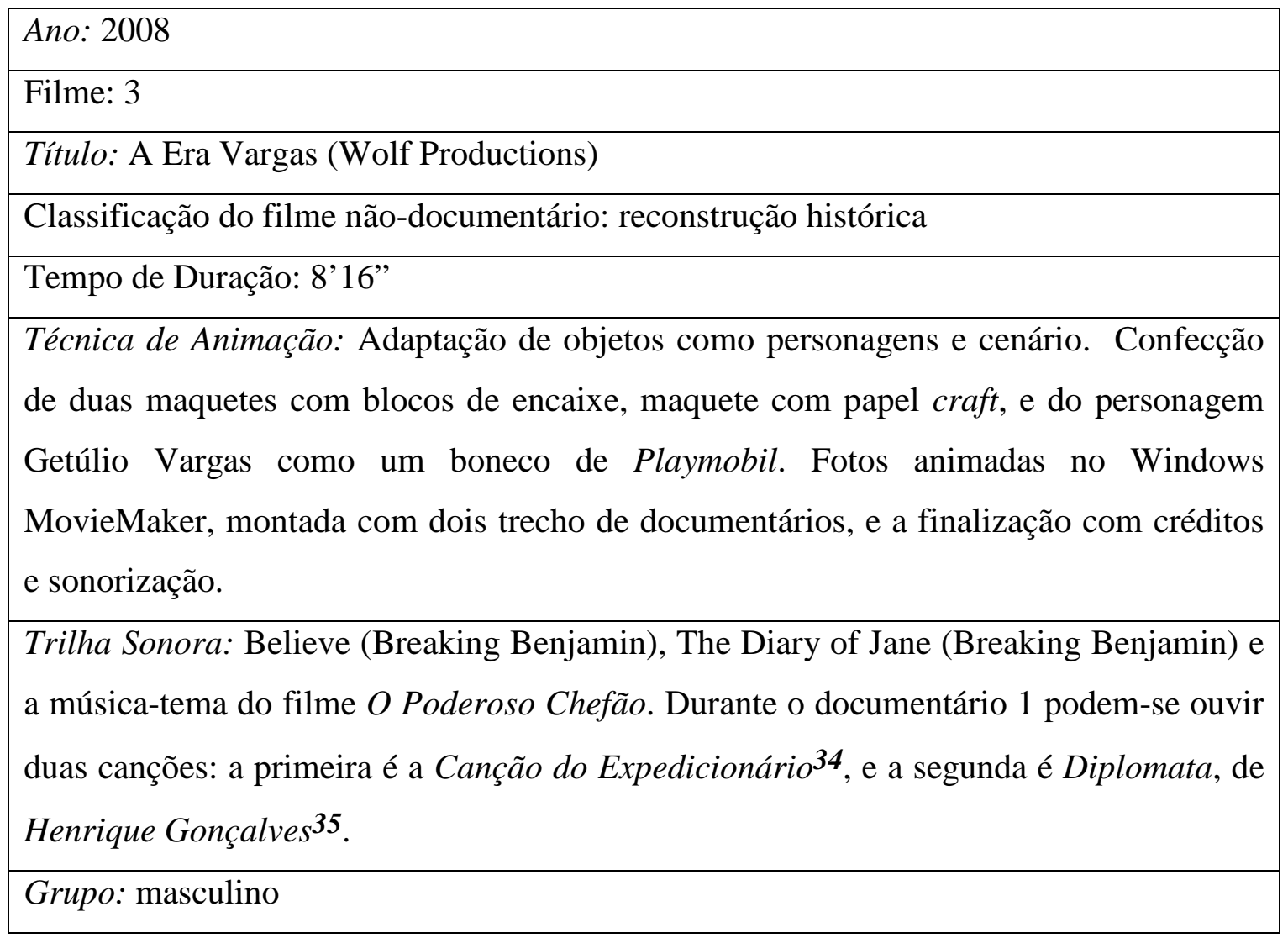

(continua)

34 Canção do Expedicionário, letra de Guilherme de Almeida e música de Spataco Rossi, em compasso de hino:

Você sabe de onde eu venho? / Venho do morro, do Engenho, / Das selvas, dos cafezais, / Da boa terra do coco, / Da choupana onde um é pouco, / Dois é bom, três é demais, / Venho das praias sedosas, / Das montanhas alterosas, / Dos pampas, do seringal, / Das margens crespas dos rios, / Dos verdes mares bravios / Da minha terra natal. / Por mais terras que eu percorra, / Não permita Deus que eu morra / Sem que volte para lá; / Sem que leve por divisa / Esse "V" que simbolizal A vitória que virá: / Nossa vitória final, / Que é a mira do meu fuzil, / A ração do meu bornal, / A água do meu cantil, / As asas do meu ideal, / A glória do meu Brasil. / Eu venho da minha terra, / Da casa branca da serra / E do luar do meu sertão; / Venho da minha Maria / Cujo nome principia / Na palma da minha mão / Braços mornos de Moema, / Lábios de mel de Iracema / Estendidos para mim. / Ó minha terra querida / Da Senhora Aparecida / E do Senhor do Bonfim! / Por mais terras que eu percorra, / Não permita Deus que eu morra /Sem que volte para lá; /Sem que leve por divisa / Esse "V" que simboliza / A vitória que virá: / Nossa vitória final, / Que é a mira do meu fuzil / A ração do meu bornal, / A água do meu cantil, / As asas do meu ideal, / A glória do meu Brasil. / Você sabe de onde eu venho? / E de uma Pátria que eu tenho / No bôjo do meu violão; / Que de viver em meu peito / Foi até tomando jeito / De um enorme coração. / Deixei lá atrás meu terreno, / Meu limão, meu limoeiro, / Meu pé de jacarandá, / Minha casa pequenina / Lá no alto da colina, / Onde canta o sabiá. / Por mais terras que eu percorra, / Não permita Deus que eu morra / Sem que volte para lá; / Sem que leve por divisa / Esse "V" que simboliza / A vitória que virá: / Nossa vitória final, / Que é a mira do meu fuzil, / A ração do meu bornal, / A água do meu cantil, / As asas do meu ideal, / A glória do meu Brasil. / Venho do além desse monte / Que ainda azula o horizonte, / Onde o nosso amor nasceu; / Do rancho que tinha ao lado / Um coqueiro que, coitado, / De saudade já morreu. / Venho do verde mais belo, / Do mais dourado amarelo, / Do azul mais cheio de luz, / Cheio de estrelas prateadas / Que sse ajoelham deslumbradas, / Fazendo o sinal da Cruz! / Por mais terras que eu percorra, / Não permita Deus que eu morra / Sem que volte para lá; / Sem que leve por divisa / Esse "V" que simboliza / A vitória que virá: / Nossa vitória final, / Que é a mira do meu fuzil, / A ração do meu bornal, / A água do meu cantil, / As asas do meu ideal, / A glória do meu Brasil.

35 Nasci no Rio de Janeiro sou reservista, sou brasileiro. / Minha bandeira foi desrespeitada, foi humilhada e ultrajada. / "Independência ou morte" é o brado da majestade. / Brasileiros do sul, do centro e do norte, soldados da liberdade, / Unidos seremos fortes, para lutar e vencer. / O Brasil espera que cada um saiba cumprir seu dever. / Felizmente nessas horas tristes, dolorosas e bem amargas, / Temos um homem de fibra que é: o presidente Vargas. / Debaixo de suas ordens quero empunhar um fuzil / Para lutar, vencer ou morrer pela honra do meu Brasil. 
(continuação)

Legendas ou diálogos escritos:

Mr. Lego como presidente Vargas

Exército do Eixo - japoneses

Exército dos Aliados - Brasileiros/EUA

Exército do Eixo - Alemães

(Vídeo 1)

Narrador: Atenção, atenção, ouvintes do Repórter Esso: o governo brasileiro acaba de declarar guerra às nações do Eixo.

“Cine Jornal Brasileiro - Forças Expedicionárias do Brasil

Rio: Desfile de fôrças militares que o Brasil enviará a lutar contra os totalitários - DIP” Narrador: Enormes multidões celebram, com as mais diferentes demonstrações patrióticas, o desfile de unidades do corpo expedicionário brasileiro na capital da república. Preparar combatentes capazes para uma guerra como a atual é tarefa que só os povos de grande tradição e progresso e extraordinárias energias cívicas e morais conseguem realizar.

(Música: Canção do Expedicionário. Enquanto isso ouve-se o narrador.)

Narrador: A criação da Força Expedicionária Brasileira marcou o engajamento do país contra o Eixo. A campanha na Itália foi marcante e transformou o exército do país.

Vídeo 2:

Narrador: Três anos depois da posse, uma grave crise política agitava o país. Todos torciam por uma solução honrosa que trouxesse tranqüilidade à nação. Tudo parecia caminhar para esse fim. Depois de 64 horas de inquietação, a cidade já repousava cheia de esperanças, certa de que os problemas e os desentendimentos houvessem sido superados, quando uma notícia dramática emocionou mesmo os corações mais frios: pusera termo à vida o presidente Vargas.

Lamenta o país a morte do presidente Vargas (manchete do jornal O Dia)

Abalada a nação pelo pranto do povo (manchete do jornal A Pátria)

"Saio da vida para entrar na História" / Legado de Vargas (manchete, não foi possível identificar o nome do jornal)

O Povo chora nas ruas a morte de seu grande chefe (manchete do jornal Última Hora)

Narrador: Carregado por parentes, amigos e pessoas do povo que disputavam essa (continua) 
(continuação)

honra os restos mortais de Getúlio Vargas foram encaminhados para o aeroporto Santos

Dumont, de onde seguiriam para São Borja, em sua derradeira viagem.

Sinopse:

O filme narra dois momentos particulares da Era Vargas: a participação do Brasil na Segunda Guerra Mundial e o suicídio do presidente.

Explorando o recurso da montagem, o vídeo combina imagens do período e a manipulação de objetos para a animação. No primeiro núcleo temático há a escolha por declarações do presidente que motivem e justifiquem a formação e deslocamento de tropas brasileiras para a Europa, com especial destaque à atuação das tropas na Itália. No segundo núcleo, apresenta certa desconfiança em relação a imagens de época que anunciam a morte de Vargas como uma tragédia que acometeu um grande líder e herói. Utilizando a ironia, ao som da canção-tema do filme O Poderoso Chefão, associam Vargas a um criminoso.

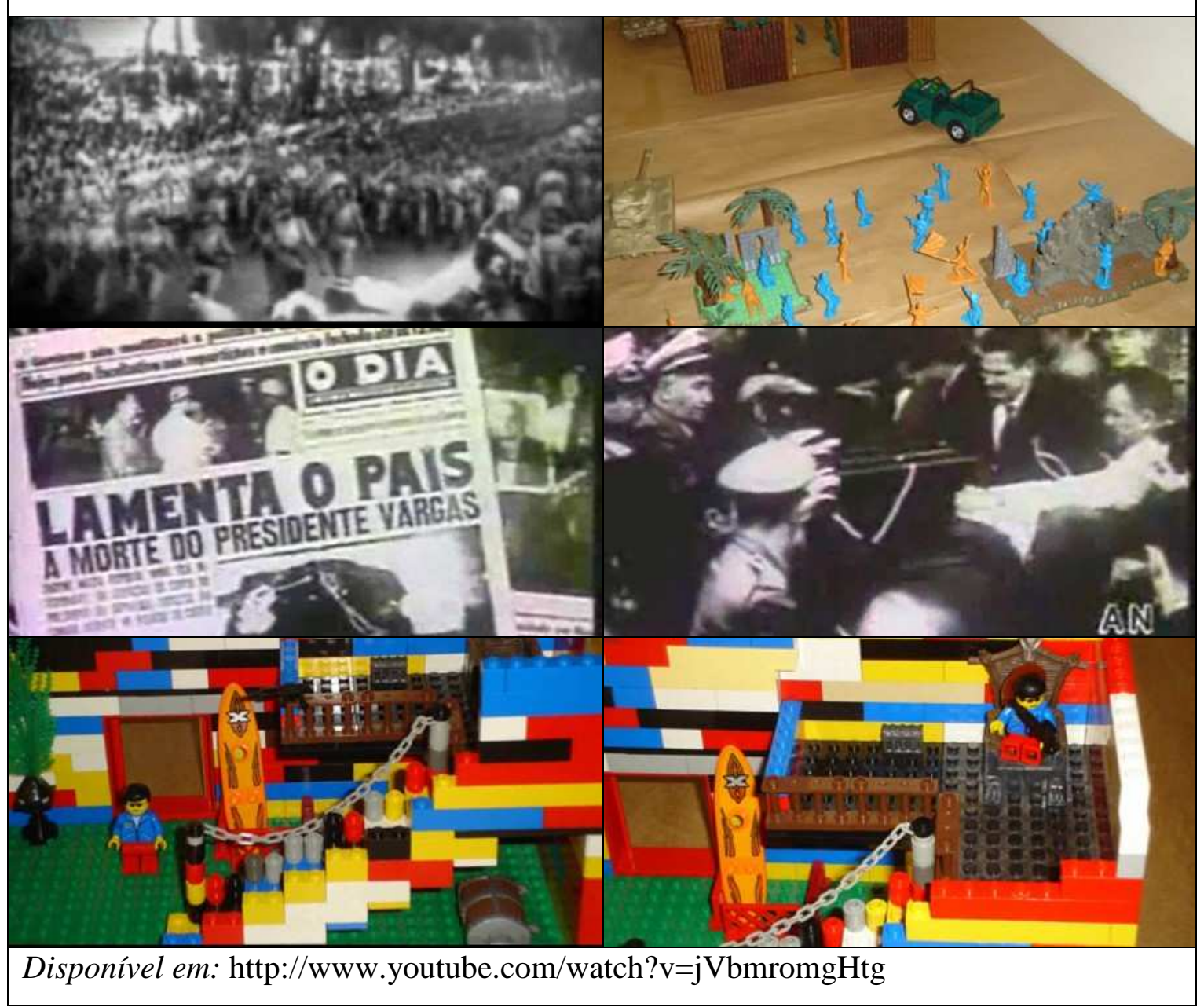




\section{A.2.4 Filme 4/2008}

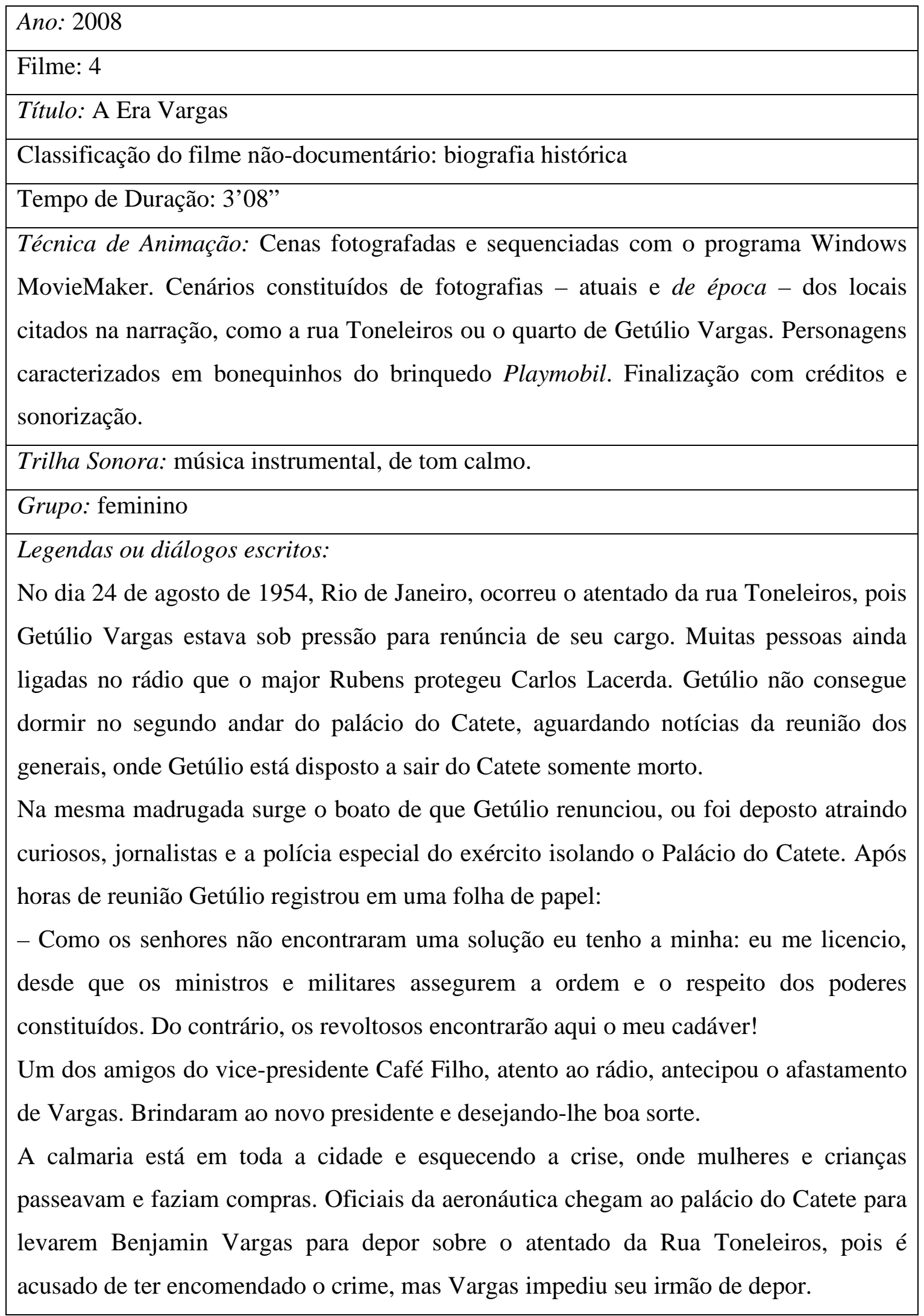


(continuação)

Logo Vargas tranca-se em seu gabinete por 3 ou 4 minutos, o ajudante de ordem e sua filha Alzininha, como de hábito estava no telefone, viram Getúlio voltar ao seu quarto com a mão esquerda dentro do pijama segurando algo.

Getúlio mandou chamar o barbeiro da presidência e seu irmão, pois soube que seu afastamento não foi aceito, e queriam sua renúncia. Despediu-se dos dois e então ficou sozinho em seu quarto. Por volta das 8 da manhã, ouve-se um tiro e um grande movimento no palácio, todos entrando e saindo às pressas.

Poucas pessoas que estavam em frente do palácio viram a chegada da ambulância. Os soldados estavam nervosos. A população ficou sabendo: Getúlio Vargas suicidou-se!

Uma carta que foi encontrada na mesa de Getúlio Vargas é divulgada. Eis um trecho que fala de sua morte:

- E aos que pensam que me derrotaram, respondo com a minha vitória. Era escravo do povo e hoje me liberto para a vida eterna. E vos dei a minha vida, e agora vos ofereço a minha morte. Saio da vida para entrar na História.

Sinopse:

O filme narra a cronologia de eventos ocorridos durante os últimos dias de vida do presidente Getúlio Vargas, desde o atentado a Carlos Lacerda - referido aqui como atentado da rua Toneleiros, no Rio de Janeiro - até o momento do suicídio. São citados, ao final, trechos da carta-testamento atribuída ao presidente.

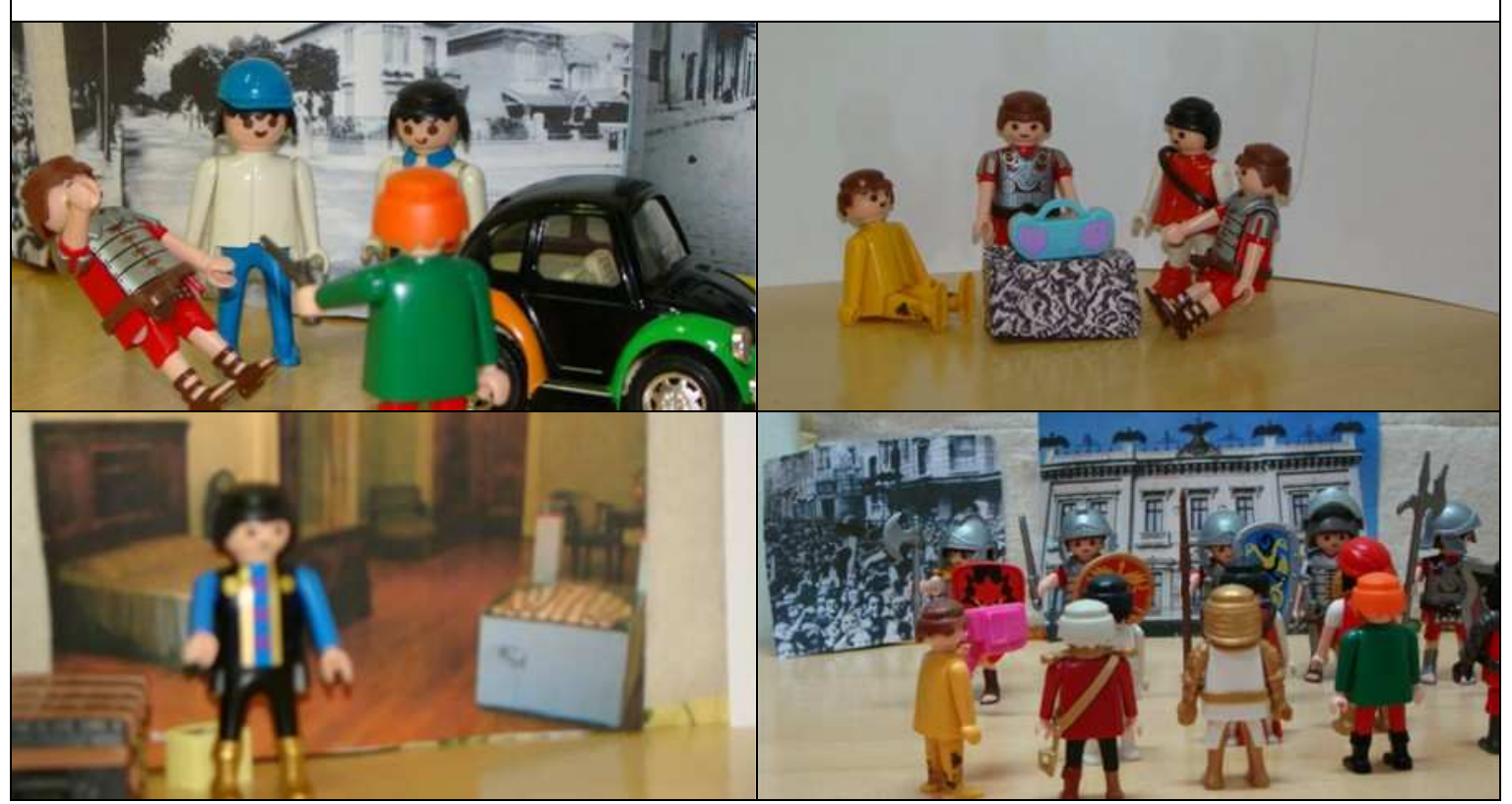

(continua) 


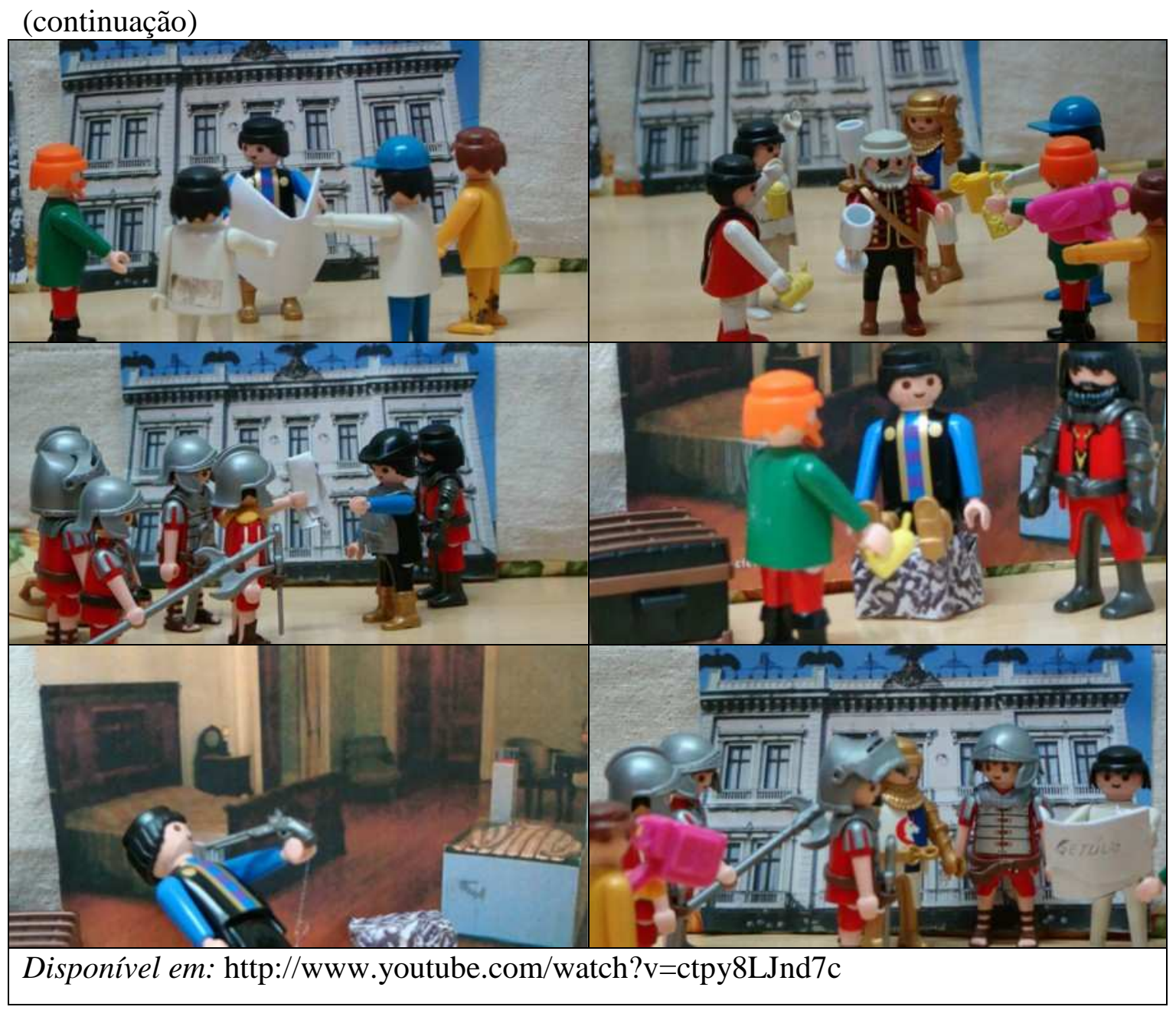




\section{A.2.5 Filme 5/2008}

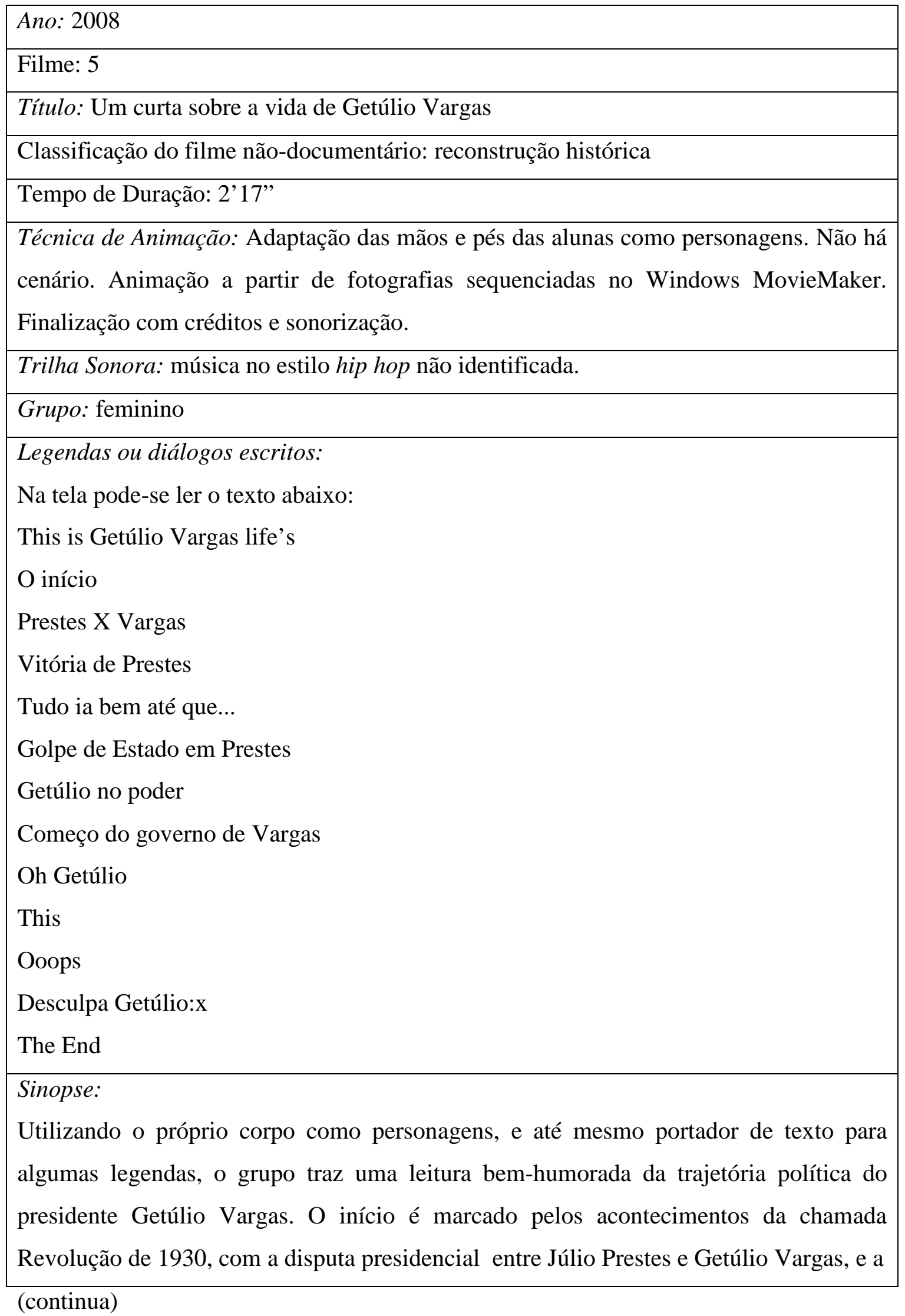


(continuação)

consequente deposição de Prestes.

No início do governo Vargas os diferentes tipos sociais que compunham a Aliança Liberal são apresentados, ressaltando a diversidade em apoio ao novo presidente. Mas a aparente sorte ou sucesso de Getúlio são alvo de questionamento, no momento em que palmas de parabéns ao gaúcho transformam-se em sua morte. De modo curioso, há um pedido de desculpas.

Ao final do filme, são apresentadas algumas informações dos bastidores das gravações.

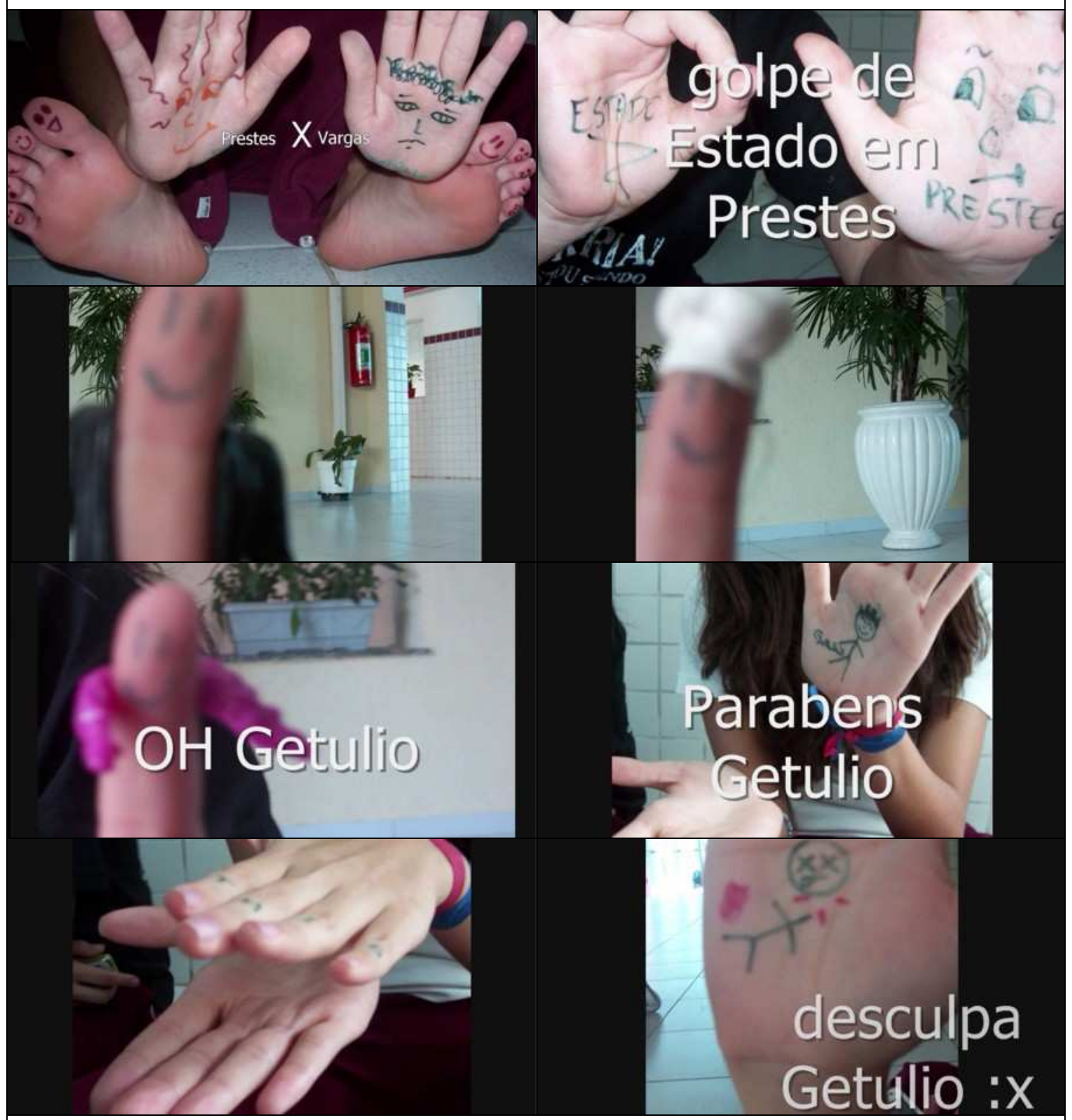

Disponível em:

http://www.youtube.com/user/profadani\#play/all/uploads-all/1/MhP9gW3zajY 


\section{A.2.6 Filme 6/2008}

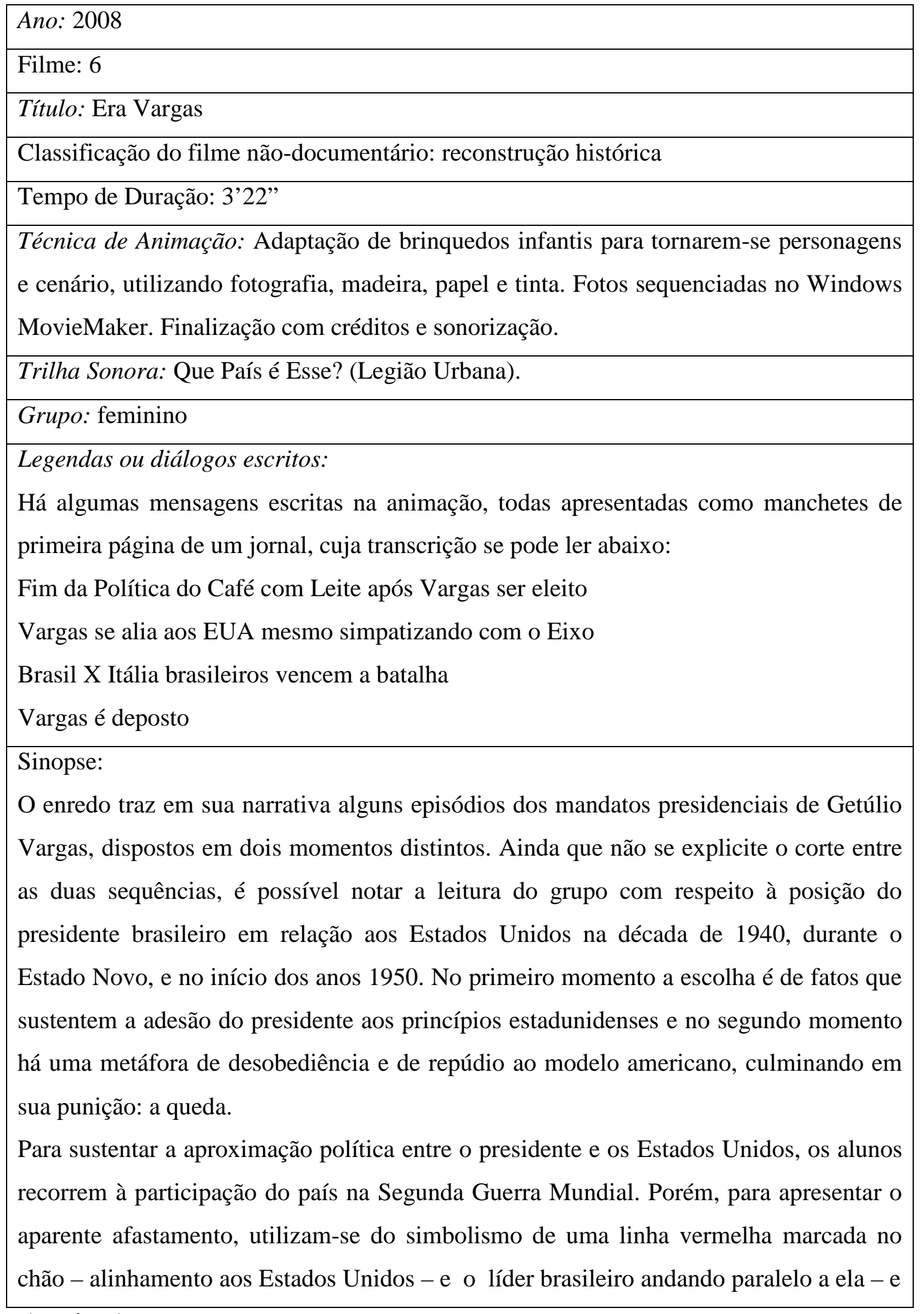
(continua) 
(continuação)

não sobre ela -, indiciando certa desobediência; o resultado é o misterioso empurrão que leva dentro do escritório estadunidense, após o qual sua reação é ir para o quarto e sentar-se na escrivaninha.

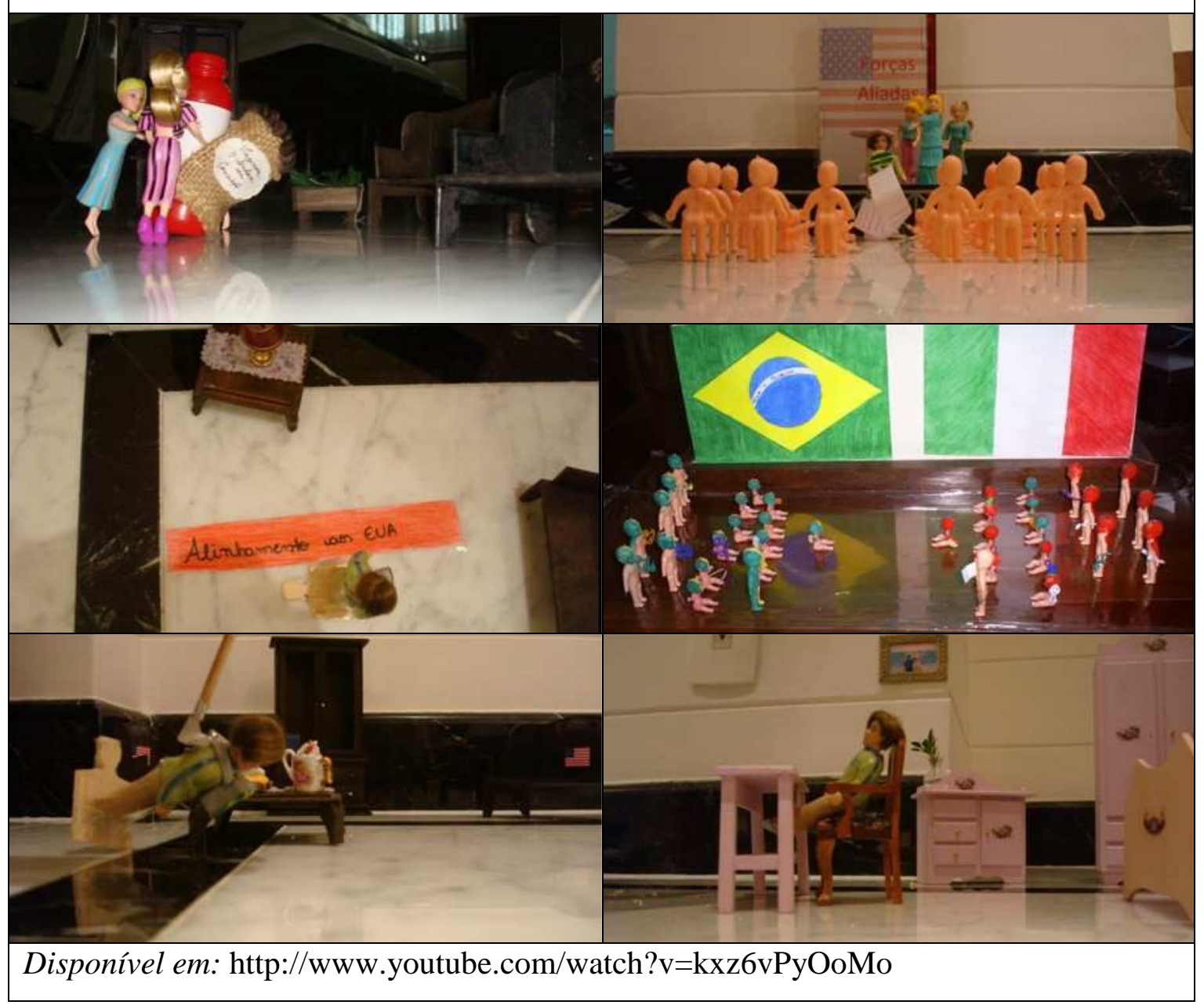

